GROTIUS SOCIETY PUBLICATIONS.

No. 1.

\title{
INTERNATIONAL RIVERS.
}

\author{
A MONOGRAPH
}

BASED ON DIPLOMATIC DOCUMENTS.

BY

G. KAECKENBEECK, B.C.L., 


\section{GROTIUS SOCIETY'S PROCEEDINGS.}

\section{PROBLEMS OF THE WAR.}

VOLUME 1, publisheil 1916.

Price 5s. net (\$1.25). Postage (6r. (12 rents).

\section{CONTENTS.}

The Position of Enemy Merchantmen. By C. S'rubBs.

The Laws of War: Prisoners of War and Reprisals. $B y$ Sir GRahaM Bower.

Neutrality and War Zones. By Rev. T. I. LAWrence and Malcolm Carter.

Destruction of Merchantmen by a Belligerent. By $\mathrm{H}, \mathrm{H}$. L. Bellot.

Bombardments. By G. G. Phillimore.

The Belgian Proposal to Neutralise Central Africa during the War. By R. C. Hawkin.

The Military Effects of Attacks on Commerce. By Judge ATHERLEY-JONES.

Some Notes on Blockade. By Sir John Macdonell. 
VOLUME 2, published 1917.

Price 6s. net $(\$ 1.50)$. Postuge bd. (12 cents).

\section{CONTENTS.}

The Treatment of Enemy Aliens. By sir Ernest SATow.

The Appam. By H. H. I. Bellot.

The Principles Underlying the Doctrine of Contraband and Blockade. By J. E. G. DE Montmorency.

War Crimes: Their Prevention and Punishment. By $\mathrm{H} . \mathrm{H}$. L. Bellot.

The Nationality and Domicil of Trading Companies. By E. J. SChuster.

Neutrals and Belligerents in Territorial Waters. By S. D. COLE.

De la Belligerence dans ses Rapports avec la Violation de la Neutralité. $\mathrm{By}$ CH. DE VIsscher.

The Effect of War on International Law. By Rev. T. I. LAWRENCE.

International Leagues. $\mathrm{By}$ W. R. Bisschop.

The Enforcement of the Hague Conventions. By W. Evans DARBY.

The Treatment of Civilians in Occupied Territories. By Sir Alfred Hopkinson.

War Treason. By J. H. Morgan.

Destruction of Merchantmen by a Belligerent. By Sir Walter Phillinore, Bt. 



\title{
GROTIUS SOCIETY PUBLICATIONS.
}

\author{
No. 1.
}

\section{INTERNATIONAL RIVERS.}

\author{
A MONOGRAPH \\ BASED ON DIPLOMATIC DOCUIIENTS.
}

BY

G. KAECKENBEECK, B.C.L., OF MAGDALEN COLLEGE, OXFoRD.

WI'TH AN INTRODUCTOIY NO'L'E

BY

HENRY GOUDY, D.C.L.,

REGIUS PROFESSOR OF CIVIL LAW IN THE UNIVERSITY OF OXFORD.

$$
\frac{1522 \times 2}{10-9-19}
$$

PUBLISHED FOR THE SOCIETY

BY

SWEET AND MAXWELL, LIMTTED,

3, CHANCERY LANE, LONDON, W.C. 2. 

IN DEEP GRATITUDE AND LASTING FRIENDSHIP,

\section{THIS MONOGRAPH}

IS

\section{Dedicated}

To

\section{G. E. UNDERHILL, M.A.,}

FELLOW AND TUTOR OF MAGDALEN COLLEGE, OXFORD. 
Digitized by the Internet Archive in 2007 with funding from Microsoft Corporation 


\section{PREFACE.}

The author wishes to introduce this work neither as a system, nor as a string of reflections suggested by experience and practice, but simply as an attempt to bring together and connect such information-scattered in numberless documents-as may be of value to statesmen, diplomatists and students of International Law, with regard to the questions raised by the existence of International rivers.

The attitude which he has endeavoured to take is essentially objective, and as impartial as the inevitable limitations of human nature permit. He sincerely believes that if he is at all biassed, it can only be in favour of a true and loyal international spirit, and in opposition to national egoism and bad faith, the mischievous workings of which he has but too often beheld with dismay.

The author is among those who, impressed by the horrors of the present $\mathrm{War}$, but too young, inexperienced, or diffident to attempt to banish war from the world at one swoop, feel, however, that the removal of every likely cause of quarrel or dispute is a gain for the cause of peace and a boon for the world.

International rivers are among the bones of con- 
tention of mankind; and just as after the Napoleonic wars the problem received its first general solutionprompted by the desire of establishing a durable if not permanent peace-it is hoped that it may, after this gigantic convulsion, receive an improved solution, less equivocal and more in keeping with the modern improvements in the means of transport and the development of international commerce. While the questions of the Danube, of the Scheldt, of the Polish rivers and perhaps of the Rhine will have to be reconsidered, why not create a new committee of navigation to improve upon, and complete, the work of the Committee of Navigation of the Congress of Vienna? A number of experiments, which extend over more than a century and have not been confined to the Continent of Europe, are available as a store of experience.

It is that store of experience which has been collected and compressed into this volume, not, as Bacon complainingly remarks of many books, "in a sort as may be soonest believed and not easiliest examined," but with the object of bringing together the materials whence knowledge can be gathered rather than of imposing conclusions without giving the premises. This method may disappoint the general reader, who requires a theory to espouse and not facts and data to examine; but it cannot fail to be welcome to all who desire to make up their own minds as to what is true and good, and to achieve practical results.

Whenever, without unduly increasing the bulk or hopelessly impairing the clearness of the work, the 
author could let official docunients speak for themselves, he has never failed to do so. Although he consulted many books, he has made but little use of them, but from treaties, conventions, regulations, protocols, \&c. the quotations and borrowings abound. Official translations have been used when available, but they have mostly been collated with the authoritative texts, and altered in a great many cases.

Two questions, which in some respects might with advantage be distinguished, have been necessarily dealt with together in this work, viz. (a), that of the opening up of an international river to the flags of all nations equally ; (b) that of the administrative arrangements between the riparian governments for the unification of the régime of the river, its supervision, the construction of the necessary works, \&c. In fact, the two questions are indissolubly connected, as the reader will easily convince himself when he meets with cases in which, freedom of navigation for all flags having been proclaimed, the arrangements between the riparian governments nevertheless resulted in making the proclamation purely illusory.

This shows that, if an International Congress attempts to deal with the question of international rivers, it will have to grapple with many technical problems for which a close collaboration of experts and jurists is requisite. The work will not in any case be satisfactorily performed by simply framing a beautiful proposition signed and sealed by a score of governments, be it ever so free from the plague of amendments and reservations. 
When this is borne in mind the main difficulties in the way of framing general principles arise from the existence of the rights of sovereignty of the riparian States (rights which must never be needlessly encroached upon), and from the variety of circumstances and localities, which is so great that often what is perfectly sufficient on one river is nugatory on another, while what is expedient in one case may elsewhere be intolerable. These difficulties, however, do not seem insurmountable.

The Congress of Vienna (1815), which did not possess the fund of experience which is available to us, confined itself to propounding general principles in accordance with which a certain unification in the régime of each river should be achieved by the common agreement of the riparian governments. No mode of co-operation was imposed. History shows that, in fact, several modes have been imagined and applied at different times with different results. In one respect the most thorough had been applied to the Rhine by the Convention of Paris as early as August 15th, 1804: it considered the river as common to France and Germany in matters relating to navigation and commerce; and it endowed the river with a common administration of an elaborate character. On the same river, in 18:31, an entirely different system prevailed, viz., that of the assimilation of the ships of the upper riparians to those of the lower riparians in point of treatment, while each government preserved its full rights of sovereignty over its part of the river. Tolerable when the lower riparian comitry itself 
possesses the greatest interest in the navigability of the river and in the cheapness of the traffic, such a system offers no security when the most important maritime port belongs to the upper riparian. In consequence, a different system was resorted to on the Scheldt in 1839, which is characterized by a dual supervision exercised by commissaries from Holland and Belgium. On the Danube, on the other hand, the striking feature is the existence of a Europeun Commission which, in the first instance, was meant to be a European Syndicate representing the interests of navigation. Intended at first as a temporary expedient, this exceptional institution was repeatedly prolonged for political reasons and as the only guarantee against the particularism and schemes of hegemony, now of Russia and now of Austria, on the Danube. Finally, the most general-and commendable-system is that of a Riparian Commission.

However bewildering this diversity of modes of co-operation may appear at first sight, it is submitted that it is not impossible to form a common principle applicable to all particular cases with the variations which may be necessitated by the differences in circumstances and localities.

From a general point of view the two principles which require most emphatic recognition are-

(1) Commercial navigation is free for all flags on the footing of perfect equality, and all particular regulations inconsistent with this freedom are ipso facto invalid.

(2) No fiscal exactions are permissible beyond (a) a 
reasonable contribution payable by passing ships towards the expenses necessary to maintain and improve the navigability of the river; and (b) a reasonable compensation for the use of special appliances.

These principles being admitted, it remains to organize the administrative co-operation of the riparian States. Shall they settle everything directly either through the agency of their Foreign Offices, or through that of functionaries appointed for the purpose? This of course is most in accordance with a radical and absolute conception of State sovereignty, but it is highly unpractical and dangerous. Or, on the other hand, shall the riparian Powers give up their individual sovereign rights over the river in favour of a condominium? This is very unlikely, is hardly consistent with legal principle, and, besides, goes further than is necessary.

The most commendable plan is that of providing the river with a special administration, including representatives of all the riparian countries on an equal footing, and having a certain degree of automony in ordinary matters concerning the navigation and upkeep of the river. Such an administration, huving primarily in view the interests of the river, of navigation and of commerce, mostly does away with the danger of friction resulting from the immediate contact of officials and departments biassed by their national and particularistic points of view. It does not, like the establishment of a condominium on the river, encroach upon the vital right of self-protection of every State or necessitate a sharing of 
sovereignty. As to the interests of non-riparian Powers, whose delegates cannot of course be admitted to the administration, they are safeguarded by the clause above mentioned (principle) that "all particular" regulations (i.e., regulations made by riparians among themselves) inconsistent with this freedom are ipso facto invalid."

The draft of an international regulation for the navigation of rivers adopted in 1887 by the Institute of International Law is perfectly consistent with the plan recommended, and, with the addition of the resolutions adopted by the same Institute at Madrid in 1911 , with regard to the use of international rivers mainly from the point of view of industrial exploitation, would serve admirably as a basis for the discussions of an International Committee of Navigation.

Having availed himself of this opportunity of expressing some reflections which, owing to the plan of this monograph, could less conveniently be inserted elsewhere, the author gladly returns to the main object of his preface, viz., that of tendering his most sincere thanks to Professor H. Goudy, Professor L. Oppenheim and Mr. C. Hurst, Legal Adviser of the Foreign Office, for kindly reading his manuscript and making many valuable suggestions. Professor Oppenheim in particular very strongly drew the author's attention to the inadmissibility of any theory involving anything like a condominium, and it is on his suggestion that Appendix I. and Appendix II. have been added. If the author ventured on publication-which was not intended at first-it is mainly 
owing to Professor Oppenheim's praise and encouragement, soon afterwards confirmed by those of Professor Goudy. In Professor Goudy, with whom he had the . good fortune to study Roman law at Oxford, the author has always found a most sympathetic and enlightened guide, whose kindness in writing a note of introduction to this publication gives the author very particular pleasure.

To the President and Fellows of Magdalen Cullege, Oxford, the author also wishes to express his deep gratitude for all the sympathy and support which he has received from them, and of which the contribution, which they spontaneously voted towards the publication of this Monograph, is but one example.

Finally, the author desires to offer his sincere thanks to the Grotius Society for kindly undertaking to publish this work.

\section{G. KAECKENBEECK.}

Oxfond, October, 1918. 
( xiii )

\section{'TABLE OF CON'TEN'TS (a).}

INTRODUCTION, 1-4.

National and International rivers, 1;-Double character of questions relative to International rivers, 2 ;- The problem of the opening up of International rivers, 3 ;-Scope and division of this work, 4 .

\section{Legal Theories and Principles, 5-29.}

I. Medieval particularism, 5 .

II. RoMAN LAW, 6-9.

Not an International system, 6;-Terminology, 7;Juridical nature of flumen, 8;-Practical distribution of rights, 9 .

III. The Law of Nature, 10-16.

Its influence and authority, 10;-Grotius' and Vattel's endeavour to supply two desiderata, $11 ;-$ Equitable limitation of dues, 12;-Right of Innocent passage, 13;-Extent of application of their doctrine of Innocent passage, 14;Authority of their doctrine, 15 ;-Historical appeals to the Law of Nature, 16.

IV. State Sovereignty and its linitations, 17-23.

Sovereignty: the stock argument of particularism, 17; Limitations of the rights of sovereignty, 18;-International co-operation to regulate navigation, no infringement of the rights of sovereignty, 19 ;-Necessity of taking Sorereignty into account, 20;-Carathcodory's proposition, 21;-Interdependence of the interests of nations, 22;-Retrospect, 23.

(a) The references are to $\$ \xi$, not to pages. 
V. The Conventional System, 24-29.

Growth of a Conventional system, 24;-Framing of general principles, 25;-Can a customary rule be said to have originated in the Conventional law of rivers? 26;Hall's Conclusions, 26 ( 1 ); - Westlake's Conclusions, 26 (в); Discussions of these conclusions, 27;-Comparative statement of the evolution of the attitude of the principal States with regard to the principle of free navigation, 28 ;-Opportunity of settling the question authoritatively, 29.

\section{The Conventional System and the Practice of States, 30-274.}

Introduction, 30 .

A. Before the Congress of Vienna, 31-42.

I. The Scheldt.

Joseph II. and the Scheldt, 31;-Opening of the Scheldt; Decree of Nov. 16th, 1792, 32 .

II. The Rhine.

Application to the Rhine of the principles of the Decree of 1792, 33;-The Congress of Rastadt (1797-8), 34; Convention of Paris on the tolls of the Rhine (Aug. 15th, $1804)$; its object, 35 ;-A "communauté," 36 ;-The river divided into sections, 37 ; - Suppression of certain dues and duties, 38;-The collection of the tolls, 39;-The common administration, 40;-Jurisdiction, 41;-Provision of neutrality, 42 .

B. The Congress of Vienna.

I. Preliminaries.

Treaty of Paris (May 30th, 1814), 43;-Article V., 44; -Free navigation, 45;-Dues on navigation, 46.

II. Proceedings of the Congress.

The Committee of navigation, 47 ;-The basis of discussion, 48 ;-The project of the Duc de Dalberg, 49;-Baron von Humboldt's Memorandum, 50;-Other memoranda, 51; -Free navigation for the riparians only, 52;-Lord Clancarty's amendment, 53;-Other questions, 54 . 
III. Regulations of the Rhine.

The navigation of the Rhine, 55;-Navigation dues and Police of the River, $56 ;--$ Collection and distribution of dues, 57 ;-Courts of Justice, 58;-Central Commission, 59 ; -Suppression of certain dues and of all monopolies, 60 ;Dues admitted; separation from customs, 61;-Neutrality in the event of war, 62 ;-Permanent annuities secured on the proceeds of the tolls, 63;--Definitive detailed Regulations, 64 .

IV. Special Articles.

Special Articles coneerning the Neckar, the Main, the Moselle, the Meuse and the Scheldt, 65 .

V. General principles (Arts. 108-116 of the Final Act).

Other rivers, 66 ;- The Powers engage to regulate navigation by common consent (Art. 108), 67;-Freedom of Navigation (Art. 109), 68;-Uniformity, Dues, Police (Art. 110), 69;-Tariff (Art. 111), 70;-Offices for the Collection of dues (Art. 112), 71;-Towing-paths and works (Art. 113), 72;-Harbour dues, ete. (Art. 114), 73;-Customs (Art. 115), 74;-Regulation (Art. 116), 75;-The final rote, $76 ;-$ The final Act of the Congress of Vienna, 77 .

\section{Applications of the principles of Viensa.}

The three stages, $78 ;-$ The interpretation of Article 109, 79 .

I. The Rhine.

The definitive Regulation of the Riparian Commission, 80;-Controversy with Holland, 81;- The Regulation of Mayence (March 31st, 1831), 82;-The Regulation of Mannheim (Oct. 17th, 1868), 83;-The principle, 8t;-Its qualifications, 85;-Waters connecting the Rhine with Belgium and with the high seas, $86 ;-$ Dues, etc., 87 ;-Other provisions, 88 .

II. The Scheldt.

From the Congress of Vienna to the Belgian Revolution, 89;-The Conferences of London (1830-1839), 90;Holland's objections, 91;-The Answer of the Powers; Holland's rights of sovereignty, 92;-Art. IX., 93;-Abolition of the tolls in 1863, 94; - The Treaty of Limits; Waterways connecting Belgium with the Rhine, 95;-Regulations, 96 ;- War buoying on the Scheldt, 97. 
III. The Danube.

The Danube before 1856, 98.

The Treaty of Paris, 1856.

\section{A. Preliminaries.}

The bases of negotiation, 99;-The "second basis," 100; -Some aspects of the discussions, 101;-Twofold aspect of the problem, 102 ;-Russia rejects the idea of a European syndicate, 103;-The "stationaries" at the mouths of the Danube, 104;-The executive Commission to consist of Riparians only; Austria wishes to confine it to the Lower Danube, 105;-Neutralization of the Delta, 106.

B. The Congress.

The text of the Preliminaries, 107;-The "Stationaries" and the neutralization of the Black Sea, 108;-The draft proposed by Count Walewski, 109;-Austria insists on dealing only with the navigation of the Lower Danube, 110;Examination of Count Walewski's draft; Austria renews her objections, 111;-Arguments for the application of the principles to the whole river, 112;-The Austrian Reply, 113 ;-A distinction, 114;-Austria accepts the application of the principles to the whole river; her amendments, 115; -Introduction of the Prussian plenipotentiaries, 116;-The definitive text, 117;-Free Navigation of the Danube and its mouths (Art. 15), 118;-Dues and Regulations of Police and Quarantine (Art. 15), 119;-Appointment of the European Commission (Art. 16), 120;--Dues to be levied (Art. 16), 121;-Appointment of the Riparian Commission (Art. 17), 122;--Dissolution of the European Commission (Art. 18), 123;--Stationaries at the mouths of the Danube (Art. 19), 124;-The prineiples of Vienna and the Congress of Paris, 125.

C. From the Treaty of Paris, 1856 , to the Treaty of Berlin, 1878 .

A. The Act of Navigation, 1857.

Execution of Art. 17 of the Treaty of Paris, 126;--The Principle of freedom, 127;-Restrictions in favour of the riparians, 128;-Sundry provisions, 129 ;-Quarantine and Pilotage, 130;-Respective powers of the riparian Governments and of the Permanent riparian Commission, 131;The Powers examine the Act of Navigation, 132;-The objections of the Powers, 133;-The defence of the Act of 
Navigation, 134;-Austrian Interpretation of the principles of the Congress of Vienna, 135;--Austrian Interpretation of the stipulations of the Treaty of Paris, 136;-Observations of the French plenipotentiary on the Austrian interpretation, 137;--The Act of Navigation to be reconsidered; Prolongation of the European Commission, 138;-An incident: Austria's sovereign rights, $139 ;-$ Six additional Articles, 140 .

B. The Public Act, 1865 .

The work of the European Commission; the Public Act, 1 11;-Analysis of the Provisions of the Public Act, 142; -The Conference of 1866,143 ; - Loan guaranteed by the Powers, 144.

C. The Treaty of London, 1871.

The Treaty, 145; - The Regulation of the European Commission for the Navigation and Police of the Lower Danube, 146.

D. The Congress of Berlin, 1878.

Preliminary Treaty of San Stefano, 147;-The Congress of Berlin, 148;-Proposition of Baron Haymerlé, 149;Exchange of views relative to this proposition, 150 ;-Provisional examination of Art. 12, 151;-Counter-proposition of Count Schouvalow, 152 ;--Vote on the principles. Adoption of Arts. 52 to 57 of the Treaty of Berlin, 153;-No fortresses. No war vessels below the Iron Gates (Art. 52), 154;-Rumania represented in European Commission. Extension of its powers to Galatz (Art. 53), 155;--Prolongation of the European Commission (Art. 54), 156;-The European Commission to frame regulations for the navigation between the Iron Gates and Galatz (Art. 55), 157;Lighthouse on Isle of Serpents (Art. 56), 158;-Execution of works at the Iron Gates and the Cataracts entrusted to Austria-Hungary (Art. 57), 159;--Provisional tax maintained in farour of Austria-Hungary (Art. 57), 1594;-Maintenance of Treaties of 1856 and 1871 (Art. 63), 160; -A new régime, 161.

E. The additional Act, 1881.

The additional Act of May 28th, 1881, 162;-The attitude of Rumania, 163. 
F. The "Commission mixte."

Austria's objects on the section between the Iron Gates and Galatz, 164; - Three Projects, 165; - The Austrian Project, 166;-The "Projet Barrère," 167;-The Rumanian counter-proposition, 168; - The "Projet Barrère" prevails; Rumania's adhesion refused, 169 ;-Increasing complexity due to political influence, 170 .

G. The Treaty of London, 1883.

Objects of the Conference of London, 171;-The riparian States of the Lower Danube, 172;-The Regulation for the section between the Iron Gates and Galatz, 173;-Russia and the Branch of Kilia, 174;-The powers of the European Commission, 175;-The duration of the "Commission mixte,". 176;-A possible explanation of the compromising attitude of non-riparian Powers, 17 7 ; - The Regulation of the navigation between the Iron Gates and Ibrailla annexed to the Treaty of London, 1883, 178;-The Results, 179;The third Stage, 180.

IV. The Congo and Niger.

The Conference of Berlin (1884-1885).

Origins, 181;- Prince ven Bismarck's speech. Freedom of commerce and freelom of navigation, $182 ;-$ Great Britain's reservations wih regard to the Niger, 183 ; - The procedure adopted by the Conference, $184 ;--$ The composition of the Committee and its mission, $185 ;-\mathrm{A}$ sub-committee, $186 ;-$ The plan followed, 187.

Act of Navigation for the Congo, 188-265.

Free navigation, 188-192;--Dues, 193-206 ; Afluents, lakes, lateral canals, roads and railways, 207214;--International Commission, 215-242;-Recourse to war vessels, 243-246;-Loans, 247-251;-Sanitary control, 252-2.53;-Navigation in time of war, 254-264;Subsequent alterations, 265.

The Niger, 266.

The Conference of Berlin and previous Congresses, $267-274$.

Innovations, 267;-Probable reason of their liberal character, 268;--First draft of the Preamble, 269;-Objections of the American p'enipotentiary, 270;-Objections of the Russian plenipotentiary, 271;-Baron Lambermont's 
reply, 272;-Solemn reservations of the Russian plenipotentiary, 273 ; - The preamble is adopted with two modifications, 274 .

\section{Conclusions: A Standard Regulation.}

The assent of the civilised world, 275;-The practical question, 276.

The Regulation of Heidelberg, 277-304.

Compulsory agreement, 278;-Navigable affluents, 279; -The principle of free navigation, 280;--Boundary rivers, 281-283;-Equal treatment for all, 281;-Navigation dues, 285;-Navigation free for neutrals in time of war, 286 ;-Protection of establishments in time of war, 287 ; Coasting trade, 288;-Free transit, 289;-Dues and duties, 290-291;-Customs, 292 ;-Police regulations, 293 ;Quarantine, 294;-The use of the stream, 295;- Works for the maintenance and improvement of the navigability, 296; - The executive authorities, 297 ;-Rights of sovereignty, 298 ;-Riparian Commission, 299 ;-Inspectors, 300 ;Tribunals, 301; Mutual agreements for nominations, 302 ;Measurement of tonnage, 303;-Floating property in time of war, 304.

\section{APPENDIX I.}

Notes on other European rivers.

A. Application of the principles of Vienna.

(a) The Elbe, 305-307.

(b) The Weser, 308.

(c) The Rivers and canals of Poland, 309-311.

(d) The Pô, 312-314.

B. Spanish and Portuguese Rivers.

(a) The Douro, 315.

(b) The Tagus, 316 .

C. Addenda to the régime of the Danube.

(a) The Pruth, 317.

(b) An Austro-Serbian Convention, 318. 


\section{APPENDIX II.}

Notes on American Rivers.

(a) The Mississippi, 319.

(b) The St. Lawrence and the Great Lakes, 320-325.

(c) The Amazon and its tributaries, 326 .

(d) The River Plate and its tributaries, 327-328.

(e) The Rio Grande, 329 .

\section{APPENDIX III.}

Notes on African Rivers.

(a) Freedom of navigation in the free trade zone, 330.

(b) The Zambesi and Shiré, 331-335.

(c) The Act of narigation for the Niger compared with that for the Congo, 336 .

\section{APPENDIX IV.}

Two Treaties relative to the Danube.

(a) Treaty of 1871,337 .

(b) Treaty of 1883,338 . 


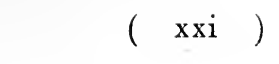

\section{BIBLIOGRAPHY ( () .}

A.

Angeberg (D'): Le Congrès de Vienne.

Annuatre de L'Institut de Droit International.

Baicoland (C. J.) : Le Danube, 1917.

Caratheodory (Et.) : Du droit international concernant les grands cours d'eau, 1861 .

- Das Stromgebietsrecht und die internationale Flussschiffahrt, in Holtzendorff : Handbuch des Völkerrechts, II., pp. $279-377,1887$.

Cúfler (J.): Pamphlet on the international law of navigable rivers, 1863.

Demorony (G.) [secretaire général de la Commission Européenne du Danube]: La question du Danube. Preface de M. Renault, 1911.

Dominé de Feret (G.): Des traités de Vienne, de Paris et de Berlin en leurs dispositions relatives à la liberté de la navigation sur le Danube, 1880.

Engelhardt (ED.): Du Régime Conventionnel des fleuves internationaux, 1879.

Histoire du droit fluvial conventionnel, 1889 (also in Nouvelle Revue historique du droit français et étranger, 1888 and 1889).

—_La Conférence de Berlin. Origines des Actes de Navigation du Congo et du Niger: in Revue de Droit International, XVIII., pp. $96-8$.

- Du principe de Neutralite dans son application aux fleuves internationaux et aux canaux maritimes, ibid. XVIII., pp. $159-167$.

(a) This bibliography comprises only books which are to be found in the great English libraries. 
Engelhardt (ED.): Le droit fluvial conventionnel et le traité de Loncires de 1^83, ıbid. XVI., pp. 360-373.

La liberté de la navigation fluviale, ibid. XI., p. 363-381. La question des péages fluviaux en Allemagne, in Revue Générale de droit international public, XVII., pp. 197 sqq. and pp. 609 sqq.

Guillaume (Baron) : L'Escaut depuis 1830, 1903.

Hertsiet: British and Foreign State Papers.

- Treaties of Navigation and Commerce.

Hyde (СH.): In American Journal of International Law, IV., pp. $145-155$.

Klüber: Acten des Wiener Congresses, Vol. III.

Martens (Ch. ve): Causes célèbres du droit des gens, II., pp. 203 sqq. (Scheldt).

Martens (F. De): Recueil des 'Traités, and contiuuatious.

Recueil des traités conclus par la Russie.

Nys (Eм.): Rivières et fleuves frontières.-La ligne médiane et le Thalweg. Un aperçu historique, in Revue de Droit International, 2nde Série, III., pp. 75-88.

Les fleuves internationaux traversant plusieurs territoires.

L'Escaut en droit des gens. Ibid. V., pp. 516- 37.

Bchuyler (Euq.): American Diplomacy and the furtherance of Commerce (VI., The free navigation of rivers and seas, pp. 265-367), 1886.

Sturdza (D.): Recueil de documents relatifs à la liberté de navigation du Danube, 1904.

'Twiss (Sre Travers): La libre navigation du Congo, in Revue de Droit International, XV., pp. 437-444, pp. 547-563, and XVI., pp. 237-246.

Le Congrès de Vienne et la Conférence de Berlin, ibid. 1885.

Vallotron (J.): Du réginie juridique des cours d'eau internationaux de l'Europe centrale, in Revue de Droit International, 2nde Série, XV., pp. 271 sqq.

Westrake (J.): La fortification de l'Escaut Occidental, ibid. XIII., pp. $105 s q q$.

Wurm (C. F.) ; Fünf Briefe über die Freiheit der Flussschiffahrt, 1858. 


\section{B.-TREATISES ON INTERNATIONAL LAW.}

Bluntschli : Introd. liberté des mers et des rivières, and $\$ \S 311-$ 316.

Bonfils-Fauchille: $\$ \S 520-531$.

Calvo: I., $§ \S 302-3+2$.

Despagnet : $\$ \$ 419-421$.

Gareis : $§ 20$.

Grotius: II., $\bullet .2, \S \S 11-15$.

HALI : § 39 .

HEFFTER : $\$ 77$.

Liszt (von) : \$2T.

Martens (DE): II., \$ $\$ 5$.

Moore: Digest, I., $\$ \$ 128-132$.

Neumann: $\$ 2.2-23$.

Nys: [1912], II., pp. 129-167.

Oppenheim : $\S \$ 176-17$ s.

Phillimore: I., $\S 125-151$.

Rivier: I., 14.

TwIss : I., § 145.

Vattel: II., $\$ \$ 117,123,126-130,134$.

Westlake: I., pp. $141-159$.

WheatoN : $§ \S 192-205$.

History, pp. 499-517.

\section{C.-PARLIAMENTARY PAPERS.}

Protocols of London Conferences, 1830-1832 (Scheldt); 1833, XLII., 1.

Negotiations of Vienna (Danube), 1854-1855, [1924], [1939], [1959] and [1964].

Protocols of Paris Conferences, 1856 (Danube); 1856 [2073], LVI., 37.

Treaties and other documents relating to the navigation of the Danube, 1856-1875 (translations); 1878 [C.-2006], LXXXII., 141. 
Correspondence relating to the Congress of Berlin, with Protocols (Danube); 1878 [C.-2083], LXXXIII., 391.

Additional Act to Public Act, 1881 (Uanube), 1882 [C.-3253]; LXXX., 249.

Protocols of London Conferences respecting the navigation of the Danube ; 1883 [C.-3526], LXXXII., 161.

Protocols of: West African Conference (Congo-Niger); 188t-85 [C.-4361], LV., 133. 


\title{
INTRODUCTORY NOTE
}

\author{
Br Professor Goudy.
}

As President of the Grotius society, under whose auspices and at whose expense (assisted by a generous donation from Magdalen College, Oxfurd) this work is being published, I have bren asked to say a few words by way of introdueing it and its author to the public. This I am happy to do though the wurk speaks for itself. The author, Mr. (r. Kaeckenbeeck, is a young Eelgian who suon after the untbreak of the War came to Oxford and took up study in the Law Schoul there. He had previous!y had a distinguished career at the University of Brussels and had also served for a short time in the Belgian Army till delicate health forced him to retire. At Oxford he went through the whole course for B.C.L., and obtained that degree with the highest honours, an unexampled event in the case of a foreigner. Soon thereafter he was invited to undertake tutorial work in law, and is now engaged in teaching pupils at Magdalen College, and under the Non-Cullegiate Delegacy, with much acceptation. He has also been appointed by London University to a recently created lectureship in law, and since the book was written has received an important official appointment in connection with the Belgian Foreign Office. His credentials therefore are of the highest. I may add, what will rapidly be discovered by the reader, that his mastery of our language and style is beyond all praise.

Mr. Kaeckenbeeck has explained in his Preface the scheme and method of the work, and most people competent to judge will agree that he has proceeded on the right lines. The bewildering mass of provisions in treaties, conventions, etc., dealing with international rivers since the beginning of last century have been subjected to a careful examination and analysis, and, so far as important, placed before the reader in a clear conspectus. Nothing K. 
of the kind, so far as I know, has ever been attempted before, and the want of it has been much felt by all those desirous of obtaining a comprehensive knowledge of the suljject. The amount of labour involved in the examination and arrangement of the material has been very great and will be appreciated by all readers even on a cursury pemsal-il saute aux yeux.

Apart from his analysis and co-ordination of the treaties, ete. on the subject, which constitute the great bulk of the work, the autho: also deals, in a brief but lucid and instructive manner, in Part I., with the legal theories and principles which have been enunciated and applied at different periods in the develupment of the doctrine of international rivers - the particularism of the Middle Ages, the system of the Roman Iaw, the system of the Law of Nature and the mudern positive system based on customs and treaties (the su-called Conventional Systens). Special attention should be given to this by the reader. Much of the confus:on of thonght and uncertainty of practice on the subject seems to me to have arisen, as our author points out, from the misuse of the term Sovereignty. An ambiguous tem at bəst, it has been constantly used by legal writers in this comnection as equivalent to property, with which however it is by no means commensurate (vide pp. 12-16).

Much yet remains to be done to put International Rivers on a satisfactory fuoting. The principles enunciated at the Cungress of Vienna of 1815 were so far sound but did not go far enough, and they failed to be carried into effect in practice. Of course. if a League of Nations is happily established after the present IIar, the difficulties will largely disappear, and it may be hoped that all navigable rivers, national as well os international. wit? be freely opened to all peoples.

I renture in conclusion to say that at the now rapidly approaching Congress of Peace and at all meetings of dip'omats, statesmen and jurists for regulating the questions that will arise regarding International Rivers in the future, Mr. Kaeckenbeeck's hook will be found of the greatest service. if not indispensable. 


\section{IN'TRODUC'IION.}

\section{National and International Rivers.}

(a) In this work, a navigable river which lies wholly within the territory of one State is described as national. Such a river forms part of the territory, and is, according to general opinion and practice, subject to the exclusive control of the territorial Power, which, however, frequently concedes to other States, by convention or as a matter of comity or policy, a right of navigation for purposes of access to its ports.

(b) A river, navigable from the sea, which flows through or along $(a)$ the territory of two or more States $(b)$, is described as international.

Between a national and an international river, there is thus this first great difference that, while the former is subject to the exclusive jurisdiction of one State, the latter is subject. in parts to the several jurisdictions of the riparian States $(c)$. In spite of this political sectioning, however, the river pre-

(a) When the international river separates the territories of two States, it is called a boundary-river, and the question then arises where-in default of special agreement-the line of demareation between the jurisdictions of the two States is presumed to be drawn ( $\$ 281-283$ ).

(b) For a somewhat different terminology, ep. Oppenheim, Intern. Law, I., pp. 239-240. Prof. Oppenheim's fourfold division emphasizes the fact that free navigation has not yet been recognized on all rivers flowing through or along the territory of two or more States; while his definition of international rivers ( $\$ 176)$, which requires free navigation for the merchantmen of all nations, reduces-when the special regulations are taken into account-the number of such rivers to a very small number, as will appear from what follows (Part II.).

(c) For an illustration of the legal difference, cp. Moore, Dig. I., p. 626, quoting Mr. Rush.

$\mathrm{K}$. 
serves its organic unity; and as it is in its physical entirety that the river is most eminently and perfectly an economic instrument, the co-existence over it of several jurisdictions with a natural tendency to exclusivism creates difficulties which place the question of International rivers among the problems of the law of nations.

2. Double character of questions relative to INTerNATIONAL RIVERS.

Whenever one of the riparian States of an international river takes a measure relative to such river or its use, not only are the effects of the measure felt by the State itself, but they necessarily react on the other riparian States, and possibly even on non-riparian States. In other words, the effects of the measure are double, being at the same time internal and external, or if one prefers, national and international. Such is at the present day the complexity of international relations and the intricate interdependence of the interests of all nations!

It is the awaking sense of this interdependence of the interests of all nations which, more than a century ago, brought the question of International rivers into prominence and led to a solution of the problem, which, though deficient and more especially insufficient, has been the foundation of the law of International rivers-in Europe at least-ever since.

3. The problia of the opening up of International RIVERS.

On the practical side the problem raised by the existence of International rivers is dominated by the question: Who may navigate an International river, and with what degree of freedom?

(a) Here we must note at once that the riparian countries of an international river are mostly not in a state of natural equality. The one that holds the mouth of the river has a master position, which may enable it to deprive all the coriparians of the most important advantage attaching to the vicinity of the river, viz., access to the sea. History shows that tho comity of nations has not always succeoded in render- 
ing impossible such ill-treatment of neighbours ( $\$ 31,319)$. In consequence, the first historical claims to free navigation mainly aim at obtaining access to the sea for the upper riparians. This, on ground of reciprocity, then implies the question of free navigation for all riparians on the whole river.

(b) But even when an agreement is arrived at, opening the international river to all the riparian flags, the upper riparians remain deprived of certain minor adrantages which the Power who possesses the mouth ean enjoy: notably, their commercial relations cannot be carried out entirely on riparian vessels; and the question then arises of the extension of free navigation to the vessels of all nations. This extension, as soon as the interdependence of interests alluded to above is clearly recognized, is often insisted upon more by commercial orersea States than by the upper riparians themselves $(d)$. But the number of eases in which freedom of navigation exists for all flags on a. footing of perfect equality is still limited.

The whole problem, whatever the degree of completeness with which its solution is attempted, has fitly been described as: the opening up of International rivers.

\section{ScOpe AND DIVISION OF this work.}

The problem is eminently a practical one, and has oceupied statesmen and diplomatists a great deal more than jurists. These, however, have never omitted to deal with the questioneven before it was seriously discussed by diplomatists - and have attempted to solve it with such juridical principles and notions as wero at their disposal, but much more according to their own idea of what was fitting and right: a practice somewhat common with the writers on the Law of Nature and stillheld in honour by many leading publicists.

Whatever be the logical and juridical value of such doctrines and of the notions and principles on which they rest, they

(d) Cp. note of Mr. Marcy, U. S. Secretary of State, to Mr. Trousdale, minister to Brazil, August 8th, 1853, concerning America's claim to free navigation on the Amazon-quoted in Moore, Dig. I., p. 642. 
have exercised an undeniable influence in history, and are thercfore entitled to the careful consideration even of the most positive statesman. But they form only an introduction to the solution of the problem, which is to be found, not in the declaration of a rule of law, but in the agreement and constant practice of States.

This work, therefore, consists of two parts: one dealing with the mair legal theories and principles; the other with the practice of States.

Fron this double inquiry, practical conclusions will then be drawn. 


\section{INTERNATIONAL RIVERS.}

\section{I.-Legal Theories and Principles.}

\section{Feudalism.}

5. Medievil particulirisim.

The system from which we have to start is rooted in feudalism, under which rivers passed from the public domain into that of the sovereign, while the impotenec of the central power and the system of fiefs then in force led to the reproduction on a smaller scale among landlords of what happened on a larger scale among kings, viz., the confusion of the public domain with private property; the appropriation of things common to all; the reign of a narrow particularism; the prevalence of a heary and complicated system of tolls and dues together with other hindrances to commerce and narigation. Every riparian landlord, every riparian town exacted tolls or dues on ships and duties on merchandise, claimed staple duties, created monopolies, enforced the transhipment or the breaking of cargoes. No limit was set. Ind as late as 1804 and 1815, long discussions still took place as to the expedieney of abolishing some of these long established rights $(a)$.

But all this was predominantly a matter of internal organisation prejudicial to everyone whether native or foreigner. Internationally, a river was generally closed to foreigners, or at least a right to close it was always claimed and often exercised; a notable instance being offered in 1648 , by Art. 14 of the Treaty of Münster, which closed the Scheldt to the Belgic Provinces.

(a) Cp. Ph. Sagnac: Le Rhin français pendant la Révolution et l'Empire, 1917, pp. $280 s q$. 
This state of things long prevailed. It was attacked mainly on two grounds:

(a) on the ground of incompatibility with the principles of Roman law;

(b) on the ground of incompatibility with the dictates of the law of Nature.

\section{Roman Law.}

6. Nót an International sistem.

The Roman Empire comprehending almost the whole of the civilised world, no truly international question could arise about rivers. The doctrine of Roman Law is adduced mainly as an argument concerning the juridical nature of rivers and the rights to which they are subject. It was an enlightened system. In that vast empire, the interest of every part was promoted at the same time as the interest of the whole.

7. Terminology.

A river is called flumen (b) or vivus, generally according to its dimensions.

But flumen, which denotes the whole river, may also denote one of the three parts of every river. Thus the stream or current is alse specifically called fumen; whereas the bed or bottom is termed alveres, and the banks ripe $(c)$.

\section{JURIDiCaL NATURE OF FLUMEN.}

(a) As aqua profluens, it is a thing common to all (Inst. II., 1, 1: "Et quidem naturali jure communia sunt omnium haec: aer, aqua profluens et mare, et per hoc litora maris").

(b) But regarded as a whole (as a river), it is strictly res publica, the use of which is open to all citizens (Inst. II., 1, $\$ \S 2$ and 4$)(d)$.

(b) Fluvius and amnis are also used occasionally as exuivalents of fumen.

(c) The true ripa is that which contains the water at its highest level.

(d) The distinction between public and private rivers does not correspond with that between navigable and unnavigable rivers (D. $43,13,2 ; \pi$. 43 . 
Here it is important to note that rivers are res publicae jure gentium in contradistinction to res publicae jure civitatis (D. $41,1,7,5)$. The State has not stamped them with this character, but has only recognized the publie character which they have received from nature itself. This distinetion has great practical importance, for although res publicae are always subject to public use, the State has a real right of ownership in the case of res publicae jure civitatis, whereas it has only a right of police and supervision to ensure free public use in the case of res publicae jure gentium.

The character of res publica of the river attaches equally to its bed and banks.

\section{Practical distribution of Rightes.}

A. To the public at large, belong:

the rights of navigation, fishing, using the banks for all purposes ancillary to navigation, as for loading and unicading cargoes, mooring, \&c.

B. To the State, belong:

1. The right of collecting a duty (titulus navium), which compensates the State for expenses of police, keeping in good repair, \&c.

2 . The right of undertaking works of canalisation, damming, \&c.; against which the riparian owners have no remedy even if they suffer damage (D. $39,3,2,3$ ).

C. To the riparian owners, belong:

1. The right of diverting water to their own use with the authorisation of the praetor.

$12,1,18$ ); but more probably with that between rivers continually flowing between regular banks and in a regular bed (flumina perenni $)$ ), and rivers having no banks or regular bed (flumina torrentia) (Ulpian in D. 43, 12, $1, \S 3$, approving Cassius and Celsus).

The question whether all unnavigable rivers, which are not flumint torrentia, are public without exception has given rise to endless discussions (cp. Jul. Weiske: Rechtslexicon, XIV., p. $86 \mathrm{sq} . \mathrm{V}^{\circ}$ Wasserrecht). But we are here concerned only with navigable rivers, and there is no doubt as to their public eharacter. 
2. The right of appropriating or sharing an abandoned bed (ratione vicinitatis) (e).

3. Alluvio $(f)$.

4. The right of sharing islands newly formed (D. 43, 12, 1, 6; Inst. II., 1, 22: pro modo latitudinis cuiusque fundi, que latitudo prope ripam sit) (e).

5. The right to undertake works in the river with special authorisation, and without prejudice to the right of third parties to claim damages, \&e.

D. Protection.

Interdicts sanction most of these rights, but sometimes there are other remedies (D. 43, 8, 2, § 9).

\section{The Law of Nature.}

\section{Its influence and aUthority.}

In whatever form it may be understood, the law of Nature has ever proved a most potent factor for the promotion of freedom in the world. Disregarding positive enactments, it boldly drew from reason and the nature of things conclusions which it asserted as binding over and above tradition and positive law. Thus it facilitated the assimilation by the law of important philosophical and moral elements, gave Roman Jurisprudence the qualities which have ensured it universal admiration and widespread application on more than one continent, and supplied the founders of International Law not only with authority but also with the majority of their leading principles.

Now, however, that the historical school has shown the inanity of some of its tencts, the law of Nature has lost much of its former authority as a source of law. But the authority of the founders of International Law whom it inspired has not thereby been destroyed. And if Natural law is but too often made to

(e) This seems to show that there is no right of ownership in the State or the Nation. Otherwise, would not an abandoned bed or an island formed in a public river belong to the State?

(f) i.e., the right to appropriate any accession to the land by the gradual and momentarily imperceptible addition of matter by the action of the water. Cp. Dig. XLI., I,, 7, 1. 
serve as a cloak to individual whims and groundless claims, the same arguments that were formerly adduced under its generic name may still prevail under the less ambitious titles of equity, humanity, morality, common interest, logic, reason. consistency, \&c.

\section{Grotius' and Vattel's endeavour to supply two DESIDERATA.}

Arguments of these two leading representatives of the school of Natural law are aimed at the practices noticed supra $(\$ 5)$, with a view to remedying:

A. The burdensome system of dues and tolls and other economic hindrances to trade and navigation;

B. The practice of excluding foreigners from the navigation of the river.

\section{Equitable limitation of Dues.}

A. Of the first point Grotius disposes as follows (II., ii., xiv.): "It is made a question whether, when merchandise thus passes through a country, the rulers of that country may impose a transit-duty. And certainly whatever taxes have no respect to the articles of merchandise, cannot equitably be imposed on them. So, neither a capitation tax, nor taxes for the general purposes of the State, can be required of foreigners passing through.

"But if, either to provide security for the merchandise, or" for this along with other objects, a burthen fall on the country, a tax may be imposed on the merchandise, if it do not go beyond the measure of the cause. That is the measure of the equity, as of other taxes, so of duties on merchandise" $(g)$.

\section{Right of Innocent passage.}

B. As to their plea in favour of freedom of navigation, it rested on two grounds:

1. Certain views-now generally discarded-about a primitive system of community replaced by a system of

(g) Whewell's translation. 
private property then prevailed. The right of passage causing no harm or damage was, they asserted, to be assumed to have been excepted and reserved when ownership was introduced (Grotius, II., 2, 13; Vattel, I., § 104).

2 . On the prineiple that (in Wheaton's words), "things of whieh the use is inexhaustible, sueh as the sea and running water, eannot be so appropriated as to exclude others from using these elements in any manner which does not oceasion a loss or inconvenience to the proprietor" (Grotius, II., 2, 11; Vattel, II., § 12\%), was made to rest the "jus utilitatis innoxiae" from which both Grotius and Vattel deduced the right of innocent passage on rivers. But whereas Grotius saw in it a perfect right legally obligatory, Vattel considered it merely as an "imperfect right" or right of imperfect obligation: forasmueh as the owner alone remains competent. to deeide whether the use of his property would cause him loss or ineonvenience (Vattel, II., \$ 128). However, he admits (II., \$ 129) that when the harmlessness of the use is not doubtful, refusal is tantamount to injury, and the party aggriered may act aecordingly.

14. Extent of applicition of their doctrine of InNocent PASSAGE.

Of course, to elaim this right of passage one must have a necessity or just eause for it; and in eonsequenee it seems that, as International Law now stands, freedom of navigation can only be elaimed on international rivers $(h)$. As Westlake says: "A state ean no more be bound to open its river ports than its seaports to foreigners. It is only when a State on an international river and an oversea State, or two States on the same international river not contiguous to one another, are desirous of such intereourse, that the ressels of either have a just cause for needing passage through the co-riparian territories lower on the river in the one ease or separating them in

(h) Not so in Grotius' time, when innocent passage on a national river might have been claimed, e.t., for a jistum hollum. 
the other case, that the doctrine of Grotius applies. The test for its application is that the narigation in question has a lawful territorial origin, and a lawful ulterior destination berond the part of the river through which the passage is claimed. The principle asserts the free use of rivers as the rehicle of intercourse not in itself affecting the country of passage, and nothing more" $(i)$.

\section{Authority of their Doctrine.}

Very few, even at the present time, are the jurists who do not directly or indirectly rely on Grotius and Vattel in the question in hand, and base their commentaries mainly on the principles laid down by their two illustrious predecessors.

One of the fundamental points at issue between publicists, concerning our question, has erer been the assertion and denial of the right of innocent passage, and $\mathrm{W}$ estlake himself judged it worth his while to tabulate the opinions of accredited authors on this point, in Internat. Law, I., pp. 158-9.

\section{Historical appeals to tire Liw of Nature.}

(a) The arguments of the United States of America for the free navigation of the Mississippi, previous to the cession of Louisiana, rested almost entirely on Natural Law. Grotius, Puffendorff, Wolff, Vattel were referred to as authorities. Roman law was also appealed to $(k)$.

(b) The law of Nature was also appealed to and widely discussed in the St. Lawrence controrersy between Great Britain and the United States of America $(l)$.

(c) In Europe, where historical precedents were much more numerous and more deeply rooted, and where the question was predominantly a fiscal one, the law of Nature played a much less prominent part in diplomatic discussions. It was, however, in the name of Natural law, and emphatically so, that the

(i) Internat. Law, I., p. 144.

(k) See Waite's State Papers, X., 135-140; Wheaton: Hist., p. 506 sq.

(l) Wheaton: Hist., 511 sq.; Congress Documents, sess. 1827-182s, No. 43; British and Foreign State Papers, 1830-31, pp. 1067-75, \&c. (see infin. $\$ \$ 319 s q q$. 
first great outburst in farour of freedom of navigation took place in the decree of the "Conseil Exécutif" of the French Republic on Norember 16th, 1792, which proclaimed that "the shackles and hindrances which hitherto have impeded commerce and navigation on the Scheldt and the Meuse are absolutely contrary to the Law of Nature which every Frenchman has sworn to uphold" (cp. $\$ 32)$.

\section{State Sovereignty and its limitations.}

\section{1i. Sovereignty: THE stock ARGUMENT OF- PARTICULARISIl.}

The principle of political sovereignty was elaborated by the old theorists with the historical and juristic aid of the idea of property and its application to the territory of a State $(m)$. Thus, from the exclusive character of property was deduced the exclusion of foreign States from interference with the territorial sorereignty which was sometimes-though we think erroneously-termed international property $(n)$.

This construction was, and still remains, the stronghold of the supporters of particularism. Vague as it was, and susceptible of extensive and absolute interpretations, sovereignty naturally was but too often made a cloak for quite unjustifiable demurs and claims, and considerably hampered and delayed the triumph of the more progressive and liberal principles. Even when free narigation could no longer be denied, it was to their rights of sovereignty that nations appealed, to withdraw in the details of practice what they had been forced to grant in principle. The framing of regulations was generally their opportunity. Thus in 1816, Holland, confronted with the Final Aet of the Congress of Vienna, endeavoured in the name of her sovereignty to render illusory the rights of the upper riparians of the Rhine; and in 1832 she pleaded her sorreignty, in order to refuse the co-operation of Belgium in the regulation and police of the navigation of the scheldt (\$§ 91-92). In 1856, Austria objected to the extension of

(m) Iloltzendorff: Handb. d. Völkerrechts, II., 225.

(n) Westlake, I., 84-88 and note, p. 88. 
the authority of an international commission to the Upper Danube, as being an invasion of her rights of sovereignty; and in 1858 , she appealed to her sorereignty to uphold regulations which the European Powers refused to ratify. It is true that, in 1883, when suing for the assent of Rumania to a measure which gave her a predominance on the Lower Danube, of which she is not a riparian, Austria endeavoured to deinonstrate that the executive character of the "Commission mixte" did not in the least infringe the sovereignty of the interested States, "laquelle (souvercineté) demeure intacte en dehors de l'application de certaines dispositions fluviales explicitement indiquées par les traités" ( $\$ 173)$; and no other Power raised any objection against this declaration $(0)$.

\section{Limitations of the rights of sovereignty.}

Breaches were made in the position of the particularistic upholders of the doctrine of property-sovereignty of nations by two sets of arguments based on very different considerations.

(a) On strictly legal ground, the notion of sovereignty was made to suffer necessary qualifications under the cover of the notion of servitude.

Both the name and the notion were borrowed from the civil law, and their justification entirely depends on the closeness of the analogy. But we have seen ( $\$ 17)$ that sovereignty and property are not exactly the same thing, and above all we must bear in mind that the restrictions on sovereignty with which we are here concerned are not conventional servitudes, but belong to the alleged class of the so-called natural or necessary servitudes which, in reality, are not servitudes at all but simply normal limitations of the right of sovereignty $(p)$.

(o) On these and many other appeals to sovereignty, see Part II.

( $p$ ) Even in private law, it is settled that servitudes are essentially exceptions to the normal order of things; and the classification of the Code Napoléon into: "servitudes naturelles," "servitudes légales," and "servitudes du fait de l'homme" has been strongly and rightly criticised. (Seo e.g., Colin et Capitant, Droit civil Francais, I., 734-6.) We fully agree with Caratheodory's contention, $\$ 11$, pp. 37-38 of his Droit International conoernant les grands cours d'eau. 
It is perhaps not inaccurate to say that, under the name of State servitude, the right of innocent passage claimed by the law of Nature acquired, so to speak, a footing in positive law, as a necessary limitation of the right of property-sovereignty of nations; and the acceptance of a natural servitude, in this case, by many upholders of that particularistic: conception of sovereignty shows in a striking manner how much the principle of free navigation on international rivers is justifiable and necessary in itself.

(b) The other argument proceeded on less positive lines. IVithout contesting the rights of sovereignty, it asserted that. like our individual rights, they are not unqualified or irrespective of the rights of others, but that on the contrary they are susceptible of abuse. To refuse to another State what belongs to it normally and by nature, or to claim exclusive rights over that which nature has conferred equally upon it and others would be such an abuse. No rights of sovereignty can justify the creation by one State of a monopoly of an inexhaustible natural force to the detriment of all others.

Without indulging in à priori assertions, we believe that, in sound jurisprudence, if the right of passage does exist at all, it exists, not as a servitude, but as a normal limitation of the rights of every State over its territory.

\section{International co-operation to regulate vavigatiox,} NO INFRINGEMENT OF TIE RIGHTS OF SOVEREIGNTY.

Whenever a river passes through or along the territory of two or more States, these States acquire ipso facto certain common interests with respect to the use of the river, and their co-operation to regulate and supervise the navigation and police of the river cannot be a violation of the rights of sovereignty of any one of them, provided there be no executive predominance of any one riparian over the others. Nor does the participation of non-riparian powers in an international Congress or Conference for the determination of the general principles regulating the navigation of international rivers infringe the sovereign rights of the riparian States; for the object of such. 
Congresses is merely the elaboration by common consent of rules of international law in which all nations are interested $(q)$.

It is only in an executive commission that the presence of delegates of non-riparian powers may be objected to as infringing the sovereignty of the riparian nations, and requires proof of real advantages to be justified. This is the only case of a possible conflict between rights of sovereignty and the interests of nations. Everywhere else the divergences-if any - are divergences of interests. Its normal limitations automatically prevent sovereignty from interfering with the adjustment of these interests. If several States recognize the existence of common interests or of possible causes of conflict, and cooperate to protect these interests or remove these eauses of conflict, in what way can this interfere with the sovereignty of any one of these States? (cp. \$92).

In fact, sovereignty has very much less to do with our question than the numerous and pathetic appeals made to it by some nations would suggest.

\section{Necessity of taking Sovereignty into account.}

It would, however, be an error to believe that a solution which took no or an insufficient account of sovereignty could be satisfactory in practice.

Attempts have been made, for instance, to solve the question by considering all navigable rivers as prolongations of the sen inland, and thus extending to them the régime of the high seas. This, of course, is inadmissible $(r)$. Nor is the analogy $x y^{2}$ straits much more helpful. In one of the exceptional cases in which it was not obviously false, it was rejected (St. Lawrence controversy). Straits connect seas; rivers do not. Rivers ramify all over a territory; they lead to the great cities and

(q) Often, without the intervention of third parties, less biassed by their own interests, no satisfying result can be arrived at. Thus, without such intervention, at the London Conferences, 1831, sqq., Holland would have proved intractable; at the Congress of Paris, 1856, Austria would probably have confined the application of liberal rules to the part of the Danube which she could not monopolize, \&c.

$(-r)$ Though this claim appeals to nature, it disrogards the very simple difference between salt water and fresh water. 
lay bare, so to say, the very heart of a country. What State would allow itself to be stripped of an elementary right off protection of its welfare and integrity? In fact, we must hear in mind that a river must be kept navigable.and in good repair, that the use of its banks is neeessarily ancillary to that of its stream, that its traffie must be subjected to an effective police supervision, and that these requisites necessitate the ( stablishment on its banks of an authority which must be powerful and able to dispose of important resources. This authority will generally be the sovereign power of each riparian State acting either directly within its territory, or by delegation as in the case of executive riparian commissions; otherwise an extraneous authority must be imposed upon the riparian States whose sovereignty is then clearly infringed. So far as sovereignty protects and sanctions fundamental national interests it cannot be disregarded any more than the interests of the community. But as soon as sovereignty ceases to coincide with the vital interests of a nation, it cannot any longer bo opposed to the general interest of the world: the two things are then incommensurable $(s)$.

In short, any extreme system, whether starting from the assertion of an unqualified sovereignty or from the unqualified denial of sovereignty, will not, at least at present, bear the test of practice $(t)$.

\section{Caratheodory's proposition.}

Since the variable and undefined term of sovereignty proves the stumbling block in all endeavours to apportion the rights of nations on international rivers, attempts have naturally been made to eliminate it from the equation of rights. Thus, under the inspiration of Roman law, Caratheodory frames the following proposition: "either as against each other or as against

(s) It is necessary to discard all notions which tend to make sovereignty a tyrant overruling covenants and good faith and, in contempt of the interests and rights of others, continually heaping up obstacles in the way of justice and progress.

( $t$ ) All this is but the consequence of the double character of questions re'ative to International rivers, which we have pointed out in $\$ 2$. 
third parties, the riparians can have no other rights than those deriving from the obligations which the vicinity of the river lays upon them" $(u)$.

This formula is attractive and interesting. Not, indeed, on account of novelty: for it has long been known that rights are correlative to obligations, and obligations to rights, and what does the formula do except to invert the usual order and propose obligations instead of rights as the starting point? nor does it attract on account of its practical character: for, if we inquire into the obligations to which the rights of the riparians are to be correlative, we receive no better answer than this: "Here, everything depends on the circumstances, on the topography, on a host of local accidents which science cannot foresee $\grave{a}$ priori, and which it might even be dangerous to try to determine beforehand."

\section{INTERdependence OF' THE interests of Nations.}

No, what attracts and captivates in Caratheodory's proposition is simply that it emphasizes the existence of obligations as between States, and is like an implicit embodiment of tho great truth that the sole and real foundation of International law is the close interdependence of the interests of all nations, and the solidarity which is the natural outcome of such interdependence. Indeed, the membership of any community, whether of individuals or of nations, necessarily involves a limitation of rights and an assumption of obligations, to which ultimately corresponds the sum of all the advantages inherent in such membership. Under ideal conditions, these advantages would be so numerous and complete, that the chief practical question would become merely the determination of every member's duties in order best to promote, with the interests of all, his own individual interest.

To revert to present realities, it is vary improbable that

(u) Caratheodory considers as a natural consequence of his principles the suppression of all difference between national and international rivers, both of which should be open to everyone without distinction. This view is shared by some other publicists.

k. 
Governments, accustomed to start from a conception of their own rights as extensive and unlimited as is compatible with their immediate interests, will change their point of view and start for once from obligations which they have always been wont to deny. Yet there is hope that, by ministering to gradually less obvious and immediate, but not less real, interests of their own, they may become convinced that such exclusive privileges and monopolies as are still possible, aro not after all so advantageous--with the illwill which they necessarily breed-as a fair system of liberty for all-at any rate apart from political scheming and ulterior motives.

\section{Retrospect.}

It we stop here to cast a retrospective glance, we find nothing as yet which enables us to say that a right of free navigation for all exists on international rivers. Those who still attribute to the law of nature some authority as a source of law often assert the existence of a right of free navigation, but it seems that, instead of declaring the law of Nations, such as it is, they take upon themselves to legislate for the world. The only conclusion which we believe ourselves as yet entitled to draw is, not that there is a right of free navigation, but that there are excellent reasons, theoretical and practical, for recognizing and applying the principle of free navigation for all on international rivers.

As to a right, no theoretical reasons and arguments can call one into existence, but only the actual practice of States.

\section{The Conventional System.}

24. Growth of a Conventional system.

If then we look at the practice of States, we find that at first claims to free navigation as of right were generally refused (cp. controversy between Joseph II. and the "Etats Généraux" concerning the Scheldt, $\$ 31$; controversy concerning the Mississippi, $\$ 319$; controversy concerning the st. Lawrence, $\$ \S 320-325)$.

However, owing to the pressure of circumstances and the 
unsettled state of the doctrine, recourse was had to particular agreements and conventions; so that what could not be suffered as a matter of right was often granted as a matter of comity or policy or reciprocity. Thus, a conventional system sprang up, which became the foundation of the law of international rivers. The more clearly the state of mutual interdependence in which nations live was perceived and felt, the more numerous and usual such conventions became. Whenever difficulties arose, a modus vivendi was established, as the only means of avoiding conflicts which a persistent refusal to yield to the necessities of the general interest would have rendered inevitable. All arrangements concerning international rivers were considered as matters of negotiation and recorded in conventions and treaties.

\section{2j. Framing of general princtiles.}

After some groping, it became clear that it was possible for States to adopt general rules applicable to all international rivers, while leaving details to be regulated with reference to special circumstances by the parties directly concerned. The advantages of such a scheme are too obvious to need comment. The Treaty of Paris (1814) laid the foundation for, and the Congress of Vienna partly realized, the scheme. The rules which were elaborated-unfortunately they were not entirely unequivocal--were successively applied to most European rivers. In some cases, they led to much discussion which throws light on them and on the improvements and alterations which they received. Nor were they confined to one Continent.

This development is set forth in some detail in Part II., where the more important treaties and regulations will be found. Concerning the possible effects of these treaties, some general considerations may be premised $(x)$.

(x) On treaties beneficial to third States, several notable examples of which occur in the matter in hand, see generally: R. F. Roxburgh: Internat. Conventions and third States, 1917, esp. Ch. V. 
26. CAT I CUSTOMARY RULE BE SAID TO HAVE ORIGINATED IN THF Conventionil L.IW OF Rivers?

It in said that the consensus of all eivilized nations repeatedly expressed or implied in a long succession of treaties may become the source of rights independent of those very treaties. In other words, treaties may in certain cases be the source from which customary law springs.

Thus it is not impossible that, on the strength of the numerous treaties and conventions which have been made to regulate the navigation of international rivers, a right can now be asserted; and it is an any rate probable that, even if the assertion be at present somewhat premature, the right will properly be asserted in the near future.

In the meantime, the question which has to be answered, after careful consideration of the diplomatic documents and transactions has been clearly put by Mr. Roxburgh $(y)$ : "Are States generally in the habit of granting such freedom [viz., of commercial navigation on international rivers] to all nations under a conviction that they are by law bound to do so?" ( $z$ ).

Now this is a question of fact, the answer to which largely depends on the interpretation of the documents, on the personal convictions of each jurist as to what amount of universality is required, what force certain reservations wield, and how long they wield it, \&c. (a). It is therefore no wonder that no agreement of opinion exists, and that, to take only two leading English jurists (Westlake and Hall), while the one asserts, the other denies, the right of free navigation.

Both authors start from a survey of the practice of Staties which in Westlake is particularly comprehensive and noteworthy, and in Hall stops before the Conference of Berlin, 188.). Both examine the question whether from such practice

(y) Ser R. F. Roxburgh, 1. c., p. 87.

(z) This conviction of a legal necessity or legal right as one of the essential elements of a custom (in contradistinction to a mere usage) has been particularly well brought into evidence by Oppenheim, Int. $L$., I. p. 22 .

(a) As to Hall's notions on the "Conventional law of Nations, see Int. $L$.. p. $7 \mathrm{sqq}$. They certainly bear part of the responsibility for his conclusions quoted infra, $\$ 26 \mathrm{x}$, and discussed $\$ 27$. 
a right of free navigation ean be deduced. We nead not apologize for quoting their conclusions at length.

\section{6a. Hali.'s Conclusions.}

"From the foregoing facts it appear's . . .; that where rivers flowing through more than one State are now open, they have usually at some time either been closed, or their navigation has been subjected to restrietions or tolls of a kind implying that navigation by foreigners was not a right but a privilege: that there are still eases in which local traffic is forbidden to non-riparians; and that the opening of a river, where it has taken place, having boen effeeted either by convention or decree. has always been eonsistent with, and has sometimes itself formed, an assertion of the paramount light of property, or in other words of the right of the owner of navigable waters to open or close them at will. It is elear, therefore, that the principle of the freedom of territorial waters, communicating, with the sea, to the navigation of foreign prowers has not bren established either by usage or by agreements binding all or most nations to its recognition as a right. It is not less cluar from: the analysis of the views of its advocates that. if not so established, it has not been established at all; hecause tho only reasonable basis on which it ean be founded requires mankind to have declared that in the case of navigable rivers the ordinary rules of accepted law must be overridden for the sako of the general good. A marked tendeney has no doubt shown itself during the present century to do away with prohibition, or to lessen restrictions, of river navigation by foreigners as a needless embarrassnient to trade, but this has been the result, not of obedience to law, but of enlightened poliey; and it may be said without hesitation that so far as international law is coneerned a State may close or open its rivers at will. that it may tax or regulate transit orer them as it chooses, and that though it would be as wrong in a moral sense as it would generally be foolish to use these powers needlessly or in an arbitrary manner, it is morally as well as legally permissible to retain them, so as to be able when neossary to exereise 
pressure by their means, or so as to have something to exchange against concessions by another power" $(b)$.

\section{6в. WESTLAKE'S CONCLUSIONS.}

"We may now look back on the history which we have traced, and ask whether it does not amount to such an accegptance of that right by the civilized world as makes international law by the consent of States. We have seen the right carried. into practical effect in Europe, America and Africa, by a series of conventions so numerous as to imply strongly that they rest on a common principle, and without limitation to the coriparians uhereter the interest of outside powers has been sufficient to induce them to intervene. This was accompanied in $1814,1815,1856$, by expressions pointing to the general application to all rivers of the principle that was being applied to some rivers on the respective occasions; and if in 1815 there was hesitation on the part of some powers as to whether the principle included any but co-riparians, the pronouncement of 1856, which included outside States in its benefit while citing: that of 1815 as precedent and authority, and was followed up in $1858 \mathrm{by}$ the rejection of narrower regulations, put for the future the larger construction on the Act of Vienna. In 1885 the principle was applied, and in its largest construction, to the acquisitions thenceforth to be made in a vast region, leaving to the powers already established within its limits an option naturally resulting from the fact that the mission of the conference was only to deal with parts still unoccupied. Lastly, the principle has taken a progressive hold: enjoyment has been claimed as an imperfect right by Great Britain ( $c$ ), which once maintained that eonvention was its only origin. IVe conclude that a sufficient consent of States exists to warrant the assertion that a right of navigation, of which the bast statement is that made for the Damube by the Treaty of Paris in 18506, exists as an imperfect right $(d)$ on the navigable

(b) Pp. 141-142.

(b) Cf. Westlake, Int. L., 1. pp. 155-156. The allusion is to a BritishPortuguese controversy of 1888 (see Ippendix III.).

(d) Not exactly in the sense of Vattel ( $\$ 13)$. Westlake means a right 
rivers traversing or bounding the territories of more than one, State" (e).

\section{Discussion of THESE CONCLUSIONS.}

Whatever may be urged against the notion of imperfect right, it seems to us that, from the present point of rien, Westlake is nearer the mark than Hall, and we believe that the weight of authority is in favour of Westlake's interpretation.

Hall, it seems to us, aceurately refleets Great Britain's attitude before 1880 , the date when the first edition of his work appeared. But Great Britain's attitude seems to have ehanged since then $(f)$, and this rery ehange, carefully noted by Westlake, is a weighty argument against Hall's opinion.

The want of universality of application of the prineiple of free navigation for all is mainly due to the faet that oversea powers have not always thought it worth their while to claim it; but whenever a real interest has induced them to intervene, the right of navigation has been granted. And we submit that wherever this right has been enjoyed, its withdrawal, even as against non-signatory powers, would be resented as an infringement of right $(g)$. No discrimination between oversea nations could be suffered, and the only differentiation in treatment which in fact exists is that between riparians and nonriparians on some rivers. This originated in 1815 , but, as a matter of principle, was set at rest in 1856, although some applications of the former stricter rule did persist much longer.

In addition to the transactions of the West African Con-

to the due enjoyment of which conventions are indispensable, but not therefore lacking every element of law or of perfect right. The right is binding, obligatory, only the details of its exercise, depending on circumstances which may vary in every case, are to be regulated by agreement (Westlake: Collected Papers, p. 75).

(e) Westlake, Intern. L., I., 157.

(f) In 1885 , cp. $\$ 275$. In 1888 , controversy concerning the Shiré and Zambezi with Portugal (Parl. Pap., C. 5904. p. 43, and Westlake, Int. L., I., 156). (See Ippendix III.).

(g) Roxburgh, 1. c., expresses the same opinion; Great Britain's contention in 1888 (see Appendix III.) illustrates the statement. 
ference of $188 \tilde{5}(h)$ and the Shiré and Zambezi controversy many facts (also posterior to 1880 and not mentioned by Hall) point to the growing consciousness that the free navigation of international rivers ultimately rests on a universal principle whose triumph, though long delayed, can no longer be denied. Indeed, so general has that consciousness become that what Hall asserted in 1880 to be the right of nations-though not, as he well pointed out, their interest-would now undoubtedly be regarded as an abuse or an infringement of right.

Among these facts, we may mention two:

(1) Ir. 1887, the Institute of International Law, though without stating any juridical ground $(i)$, declared the making of agreements regulating the free navigation of international rivers obligatory. (See $\$ 278$.)

(2) In 1899, in their award in the British-Venezuelan boundary dispute, the arbitrators decided "that in time of peace the rivers Amakuru and Barima shall be open to navigation by the merchant ships of all nations. . . . " $(k)$.

But in order to trace this growing consciousness and to detect the psychological element which alone can turn a mere usage into a customary rule, it seems that the best means is to set forth, from a few salient facts and official utterances, the evolution, so to say, of the attitude and riews of the prineipal. States, with regard to our question.

28. Comparative statement of the evolution of the attitude of the principal States with regard to TIIF PRINCIPLE OF FREE NAVIGITION.

\section{A. Germany.}

The evolution is as elearly marked as possible: In 1815, the equirocal attitude of the German States bordering the Rhine led to a regrettable ambiguity in the Final Act of the

(h) Cp. $\$ \S 182,183$, and see reservations stated and diseussed ( $\S \S 273-274$ ).

(i) The members were divided on the subject.

(k) Martens, N. R. G., 2nd série, XXIX., p. 587. 
Congress of Vienna, and in the application of its principles to the Rhine and other German rivers, the restrictive interpretation prevailed ( $\$ 53$ ).

In 1856, however, and without prejudice to the interpretation of the Final Act of the Congress of Vienna, Germany upheld the wider interpretation of the Treaty of Paris as against. Austria.

In 1868, Germany abandoned its particularistic attitude by proclaiming the principle of freedom of navigation on the Rhine for the ships of all nations in Art. 1 of the Regulation of Mannheim ( $\$ \S 83-84$ ).

Finally, in 1885, Prince von Bismarck, as ehairman of the Conference of Berlin, declared that "the Congress of Vienna, by proclaiming freedom of navigation on the rivers which flow through the territories of several States, sought to prevent any monopoly of the advantages inherent in a watercourse. This principle, he added, has passed into International Law, hoth in Europe and in America. ..." (See $\$ 182$.

\section{B. Austris.}

The fluctuations in Austria's attitude are to be understood simply by reference to her political interest. When she imposed on Parma and Modena the application of the principles of Vienna to the Pô, these principles were most widely interpreted. When the Treaty of Paris (1856) could not be confined, as Austria wished, to the Lower Danube, Austria upheld the strictest interpretation both of the principles of Vienna and of the Treaty of Paris. From that time her attitude has always been that most suitable to the extension of her hegemony over the Danubian States ( $\$ 105,110,111,113,134,135$, 136).

\section{Great Britain.}

In her disputes with the United States of America, Great Britain has consistently refused to recognize a right of free navigation by natural law. For her the question was purely a matter for conventions ( $\$ 320-325$ ).

In Europe, at the Congress of Vienna, 1815, Lord Clancarty 
insisted on a clear recognition of freedom of navigation for all nations ( $\$ 53$ ), and in 1856 and 1858, Great Britain was foremost in upholding the most liberal interpretation of the principles of Vienna and of the Treaty of Paris.

In 1885, at the Berlin Conference, the British plenipotentiary declared, on the question of free navigation, that "the question for practical consideration will be, in the opinion of H.M.'s Government, not so much the acceptance of the general principles as the mode of their application" . . . (\$ 183).

In 1888, in the Shiré-Zambezi controversy, Great Britain's attitude seems to have been founded on the recognition of a right of navigation cren apart from treaty. (Westlake, Int. L., I., 156 .

\section{France.}

Foremost in declaring international rivers open to all (1792, $\S \S 16,32)$, France has always upheld the most liberal views in the great International Congresses.

\section{E. Ittaly.}

When the Pô became a national river, Italy did not close it to foreign flags; and in 1885 she suggested the opening up of national rivers as well as international rivers.

\section{F. Russia.}

On account of Count Kapnist's reservations at the Conference of Berlin, 1885, it is important to recall that in 1883 , when Russia resumed her authority over the branch of Kilia (Danube), the principle of free navigation was not questioned, Russia haring proclaimed that "it could no longer be in question, neither to-day nor ever; neither here nor anywhere else."

In fact, the reservations were mainly directed against the system of international commissions ( $\$ 273$ ).

\section{G. United States of Anerica.}

The United States of America made also some reservations in 1885-which might easily be misapprehended-and did not 
sign the General Act. But the reservations were aimed at the uperation of the Treaties of Vienna and Paris, which cannot bind America, and they contain no denial of the right of free navigation.

Otherwise the attitude of America is clear and consistent. She has always contended in favour of the right of free navigation based on the law of nature.

The St. Lawrence controversy is enlightening in this respect (Appendix II., litt. 6). With regard to the Amazon, a note of Mr. Marcy, Secretary of State, to Mr. Trousdale, minister to Brazil. Aug. 8th, 1853, shows the position unmistakably: "This right," it is said, "is not derired from treaty stipulations-it is a natural one-as much so as that to narigate tho ocean, the common highway of nations."

And further on, we read: "We claim for this Continent' (the American Continent) the same privileges which nearly forty years ago were arranged by common consent and have ever been since (sic) applicable to the narigable waters of Europe. The regulations adopted by the allied sovereigns at the Congress of Vienna, in 1815, on this subject were but the recognition of the law of nations in regard to the use of navigable rivers passing through different realms" ( $(l)$.

Imbued with such principles, the United States Governments have on many occasions used persuasion, threats or compulsion with South American States to obtain free navigation (\$326).

\section{General.}

In most cases when reservations were made by States, as in 1885 by Russia, these reservations did not contest the principle of free navigation, but related only to particular modes of applying or ensuring it, which they did not wish to soo generalized.

The impression of the reader of the numerous treaties relating to international rivers may be that the treaties opening rivers to the navigation of foreign flags are a minority, while treaties regulating the collection of dues, \&c. between riparians are

(l) Moore, Dig., I., p. 643. 
much more frequent. But it must be pointed out that no conclusion can be drawn therefrom. Treaties dealing exclusively with such arrangements between riparians are not inconsistent with the recognition and application of the principle of free navigation. With respect to the Elbe, for instance. numerous conventions have been made concerning the tolls, their collection, tariffs, \&c. . . . They make no mention of a right of navigation; but that right had been recognized in 1821. As a matter of fact, the two kinds of conventions may be considered as distinct. They answer different purposes.

29. Opportunity OF SETtling THE QUESTION AlThoRITATIVELY.

Whether, on the grounds stated, a right exists or not is preeminently a question for the jurist. The statesman, on the other hand, unless he be content with setting seals upon the past, is not confined to this. He must look ahead. He must enquire, for example, whether certain interests are worth protecting, and if they are, he must see that they are protected. In this way, sometimes, he is something of a legislator. The statesmen who in 1815 laid down the rules applicable to the navigation of international rivers in Europe, were in a sense legislators. Unfortunately, they were not sufficiently mindful of this their cxalted task; and their particularistic habits prevailed over the liberal broadness of mind desirable in persons called to legislate for the world.

It is after a long series of wars, at the moment of reconstructing Europe, that our question came to the front; it is among the final international settlements of peace that the rules arrived at were embodied.

There are signs, at present, that the question will once more become prominent. In the countries whose fate will have particularly to be decided after this war, questions like those of the Danube, of the Polish rivers, of the Rhine, of the sicheldt, \&e., will call for particular attention.

Countries which hitherto had taken no part in the discussions concerning the narigation of international rivers are becoming 
alive to the immense importance of the problem even for them (m).

Innumerable experiments have been made not only in Europe, but in America, in Africa, and even on some rivers of Asia ( $n$ ), which furnish a valuable mass of precedents extending over more than a century. Is not an opportunity offered, among the many problems which will have to be solved after this war, to make use of all that accumulated experience in order to settle a vexed question in conformity with the present needs of international commerce and intercourse? Will there not be occasion for an International Congress of Navigation where, not simply a few Powers with particularistic interests, but most Powers of the World, will send representatives with instructions to settle a question, not only of national, but of international importance?

If this humble work could be of any use to some of the statesmen who may have to investigate this question, the author's whole ambition would be rewarded.

\section{The Conventional System and the Practice of States.}

30. Introduction.

The practice of States during the last 150 years copiously illustrates what we have said in our sections entitled "The Conventional System" (24-29).

The question of the opening up of International rivers arises, at the end of the 18th century, in much the same way both

(m) Plans for the connection of the Rhône and the Rhine appear to be under serious consideration in Switzerland. See an article signed André de Bavier, in the Westminster Gazette of January 16th, 1918, entitled: "Swiss Independence." On Switzerland and our question, see also J. Valotton, in R. D. I., 2, XV., p. 273, quoted $\$ 88$, n. 1 .

(n) Cp. Despagnet, Droit internat. public, pp. 648-9, on the Peiho and Wang-pou; Hertslet, Commercial treaties, XXI., p. 296, on the YangtseKiang. 
in Europe and in America. Upper riparians claim access to the sea, which is refused them as of right. Law being of no avail, the method of diplomacy is the obvious alternative. The Rhine furnishes the most interesting example of the working: of the conventional system; and it is from the Regulations agreed upon for that river in 1815 that the general principles of the Congress of Vienna are deduced. These principles form the almost universal foundation of the International Law of rivers. Yet they are not the last word in this matter; for their historical applications have led to modifications and extensions of the greatest importance. Fortunately, the great discussions concerning the principles and their interpretation, the important innovations and the typical regulations, refer, all of them, to a very small number of rivers which have, so to sar, monopolised the interest of the Great Powers.

This is why, when fourteen Powers assembled in Berlin in 1885 to discuss, among other questions, that of the free navigation of the Congo and the Niger, it could rightly be said that "The Conventional régime of the Rhine, that of the Scheldt, that of the Parana and Uruguay, and finally, that of the Danube, contain all the principles that now constitute International Law with regard to navigable watercourses which are common to several States."

Thus it is the body of principles adopted by the Congress of Vienna in 1815 that is the central point of our study. We have to consider how they originated, what they are, how they have been interpreted and applied.

This last part will be far the longest of our study, not only owing to the complexity of the political problems with which it is, so to say, interwoven, but also owing to the number, interest and importance of the discussions to which it has given rise.

To fix the true character and value of this history, we mas again quote the Report of the Committee of Navigation to the Conference of Berlin, 1885, which says: "These precedents show the phases through which international legislation concerning watercourses has passed since 1815; they furnish a commentary on Arts. 108 to 116 of the Final Act of the 
Congress of Vienna, and fix their sense in a manner that has the authority of principles and the sanction of experience to sustain it.'

\section{A. Before the Congress of Vienna.}

31. Josepir II. ANd the Scheldt $(\boldsymbol{n})$.

Art. 14 of the Treaty of Münster, 1648, had for ever clused the Scheldt to the Belgic provinces, thus ruining the commerce of Antwerp. During a journey in the Netherlands, Joseph II., "who could not see one of the finest rivers of the world shut to commerce, and his subjects deprived by policy of the advantages that nature had given them," resolved to put an end to this iniquity. About the same time, the Dutch ports having been elosed to British ships, the necessity of obtaining new markets was realized in London commercial circles, and brought about a movement of opinion in favour of the opening of the Scheldt (1780-81). But Joseph II.'s policy did not take a definite course until 1781, when Conferences were held in Brussels with a view to settling differences which had arisen between the Emperor and the Dutch Etats Généraux. On May 4th, the Count de Belgiojoso presented a "Tableau sommaire des prétentions de l'Empereur." On August 23rd. a note demanded the opening of the Scheldt with complete freedom of navigation, liberty for the subjects of the Emperor to trade and navigate between their ports and the two Indias. and authority for the Emperor to regulate the customs as H.M. thought fit. It was an ultimatum. The Etats Généraux. however, rejected Joseph II.'s claims, and the Emperor consented to abandon his other pretensions if the Dutch opened the Scheldt to his subjects. The Dutch then requested tho mediation of France and Great Britain $(o)$. France accepted, and on November 8th, 1785, the Treaty of Fontainebleau was signed. The Emperor abandoned his pretension to the opening of the Scheldt in consideration of ten million florins, nearly half of which was paid by France $(p)$.

(n) See De Martens, Causes Célèbres, Cause VIII.

(o) See De Martens, 1. c., p. 260, note.

(p) On the policy of France in this conjuncture, see Flassan, Hist. de la 
Thus failed the first serious attempt to claim freedom of navigation on an International river. The French Revolution swept away obstacles more irresistibly.

32. Opening of the Scineldt-Decree of Nor. 16\%11, 179\%.

In 1792, the "Conseil Executif" of the French Republic, relying on the Law of Nature ( $\$ 16$ ), declared in respect to the opening of the Scheldt: "(2) That the stream of a river is the common, inalienable property of all the countries which it bounds or traverses; that no nation can without injustice clain the right exclusively to occupy the channel of a river and to prevent the neighbouring upper riparian States from enjoying the same advantages; that such a right is a remnant of feudal servitude, or at any rate, an adious monopoly which must have been imposed by force and yielded by impotence; that it is therefore revocable at any moment and in spite of any convention, because nature does not recognize privileged nations any more than privileged individuals, and the rights of man are for ever impreseriptible."

33. Application to the Rhine of the principles of the DECREe of 1792.

The Decree of 1792 opened the navigation of the Scheldt and the Meuse. Its principles were re-affirmed and extendex to. the Rhine by the Treaty of the Hague, signed by France and Holland on May 16th, 1795, Art. 18 (Martens, R. VI., 535). Irt. 11 (patent) and Art. 2 (sceret) of the Treaty of CampoFormio, 1797 (Martens, VII., 212 and 216), still better illustrate the eagerness of the French to apply and spread the principles of 1792 .

\section{Thr Congress of Rastadt (1797-8).}

At the Congress of Rastadt, they went further. Not content with claiming the application of their doctrine to the Rhine, they stated the principle that the ships of foreign nations should

Diplomatie Française, VII., 399-410. Though she wanted to avoid difficulties with the Emperor, France could not permit any considerable diminution of the Dutch power at the moment when she was negotiating a treaty of alliance with the Etats Généraux. 
he admitted to navigate the Rhine with the consent of the coniracting Powers, and they expressed the wish that the tributaries of the Rhine as well as the other great rivers of Ciermany should be open to French vessels. (Engelhardt, N. R. H., 1889, pp. 82-3; also p. 86.) The (ierman statesmen demurred, pleading their right of sovereignty, and the clause concerning the opening of the German rivers had to be withdrawn. The Congres: then came to a sudden and untoward end, but its discussions were not entirely fruitless. The essential conditions proposed at Rastadt were reproduced at the Conference of Ratisbon, $180 \%$, and on this basis was elaborated, in 1804 , the "first modern Code of the International Law of rivers," now to be noticed.

Convention of PARIS ON THE TOLL OF THE NAVIg.tTION OF thr: Rhine (Agg. 15tit, 1804) (Convention de

$$
\text { L'OCTROI DU RHIN). }
$$

35. Its овJECT.

This convention $(q)$, made in execution of Art. 39 of the "Recès de l'Empire Crermanique," April 17th, 1803, and signed in Paris on August 19th, 1804, had a twofold object, namely:

(1) to ensure the collection of the funds necessary " to make up an endowment for the Elector Archehancellor and the indemnities granted to several other Princes and States";

(2) to encourage the navigation of a river "common to the two contracting Powers" $(r)$.

In fact, the extension of France to the left bank of the Rhine had rendered impossible the continuance of the fiscal régime, which had weighed heavily on the navigation of the river. A reform was needed-a reform not easy to achieve, owing to the reluctance to give up certain profitable rights from which princes derived their endowments, and towns their resources,

(q) Recueil des principaux traités, 2nd ed., rev. et aurm. par le baron ('h. de Martens, VIII., 261 sq. (Goettingen, 1839)-Klüber, Acten des Wiener Congresses, III.

(r) Preamble.

K. 
without finding a substitute more appropriate to the new conditions. Under these circumstances, the idea of a common and unified organization of the tolls on navigation, ensuring an easy system of collection to the benefit of all interested parties. and raising no obstacles to the river traffic, was agreed upon.

\section{A "Communauté."}

It might have been possible-it was done later on-for both partios to fix upon identical tariffs and a uniform mode of collection, and to act separately according to the same rules. But they went further, and ereated a kind of community (communauté), probably owing to the Rhine's being a boundary river and the two sovereignties being separated only by its "thalweg."

At any rate, such a solution is interesting, considering what a narrow and jealous conception of sovereignty then prevailed in the Rhenish States; at the same time, it was clearly the most simple and adequate solution in the circumstances.

The basis of the Convention is set forth in Art. 2: ". although the thalweg of the Rhine forms, as regards sovereignty, the boundary between France and Germany, the Rhine shall always be considered, in matters relating to navigation and commeree, as common to both Empires, . . . and its navigation shall be subject to common regulations."

\section{The River divided into sections.}

The next Article directs that the narigation on the upper, middle or lower sections of the Rhine "shall be performed by the boats whose build and tomnage is most appropriate to each of these sections respectively, and by the skippers who are most likely to have the best knowledge and experience of it." Hence the necessity for maintaining certain privileges of Cologne and Mayence as "villes de station." It is precisely to the section between these two towns that the regulations of our convention apply. The narigation on this section is $\mathrm{cm}-$ trusted to recognised companies, so that the boats navigating in the other sections, when they arrive at either Mayence or Cologne, are obliged to unload their cargoes, which are then transhipped upon boats belonging to these companies. 


\section{Suppression of certain dues axd duties.}

Observing that these provisions have in view the interest of eommerce, and not at all its subjection to the "villes de station," Art. 8 goes on to say: "it is agreed:

"(1) that the right of staple, properly speaking, i.e., the compulsory putting up for sale of goods or eommodities during their stay in the harbours of Mayence and Cologne, is definitirely suppressed and abolished;

. ( $\boldsymbol{Z})$ that all the dues or duties hitherto collected in the harbours of the said towns by virtue of staple, of which it has just been the question, or of forced harbour or of port (retache forcée et échelle), \&o., under the names of duties of staple, of transit, of access or under any other denomination or pretext whatsoever, shall cease entirely . . . . and that no duties shall be paid over and above the tolls, except for the cranes. quays, public weights and warehonsing, when necessary. . . All of which are contributions to the expense of keeping the requisite establishments.

\section{The collection of the tolls.}

The tolls are to be collected beforehand and in proportion to the distance contemplated (Art. 93). They include a duty of "reconnaissance" based on the tonnage ("jaugeage") of the boat (Art. 94), and a duty to be paid for erery quintal (50 kilogs.) of cargo (Art. 99). There is an abatement for heavy materials or supplies necessary to the population on either bank.

These tolls have nothing in common with eustoms-duties, which each State is free to impose or maintain on goods entering into, or going out of, its territory (Art. 11).

The tolls are to be collected in twelre offices, six on ach bank $(s)$ (Art. 46 ).

(s) There appear to have been formerly thirty-three tolls from Basle to the Dutch frontier. Cp. Ph. Sagnae: Le Rhin trança's pendant la Rírolution et l'Empire, Alcan, 1917, p. 281. 
40. The common administration.

The collection of the tolls, as well as the police of the river, is entrusted to a common administration constituted as follows:

At the head there is a general director, sworn in, and appointed in common by the riparian Powers (Art. 48). $\mathrm{He}$ is helped by four inspectors, of whom two are chosen by the French Government, the other two by the Arch-chancellor (Art. 49). The collectors and superintendents are designated by the respective governments, and the lower officials by the genera! director (Arts. 50 and 51).

The boats used for the service hoist a flag with the colours of each Empire on each half (Art. 88), and the officials wear a special uniform with the word Rhenus on the buttons.

For convenience' sake, the measures of eapacity in use in the riparian States are reduced to a common unit. The duties are collected in French money on the left bank, and in German money on the right; and a fixed ratio is established between the two kinds of money (Art. 107). "The accounts of the collectors on the left bank are in French, and those of the superintendent in German; and vice vers $\hat{a}$ on the other bank.

The police regulations are the same on the whole extent of the river.

41. JuRisdiction.

Complaints against the collectors are investigated by the general director, with the help of two inspectors (Art. 122). Appeals against their decisions may go to a commission sitting once a year at Mayence and composed of one French commissary, one German commissary and one jurist ehosen by the two commissaries (Art. 123).

It is forbidden to set up, either in order to invalidate the provisions of the convention, or in order to supplement or interpret them, any treaty, constitution, statute, decree, regulation or eustom of a later date (Art. 128).

42. Provision of neutrality.

In case of war "between any of the co-riparians of the Rhine, or even between the two Empires, the colleation of 
the tolls is to continue uninterrupted, without any obstacle being thrown in the way by either party. The boats and officials in the service of the tolls shall enjoy all the privileges of neutrality. Guards shall be provided for the oflices and the safes of the tolls" (Art. 131).

Such, in broad outline, is the common organisation to which-as far as regards commerce and narigation, as Art. 2 says-the riparian States of the Rhine delegated in 1804 the exercise of their rights of sovereignty.

When, after the Napoleonic wars, the navigation of the Rhine was, in conformity with the preliminary Treaty of Paris, 1814. subjected to new regulations, this svstem was, as we shall see, partly rejected.

\section{B. The Congress of Vienna.}

\section{Preliminaries.}

43. T'reaty of Paris, May 30tit, 1814.

We have seen how the existence of an international river confronts different interests. The possibility of a conflict between them is a danger, for the removal or lessening of which the obvious method is to connect them by giving them a common object in a common undertaking equally profitable to all. This, the authors of the Treaty of Paris did not fail to recognise. They aimed at ensuring permanent peace; they wished to remove all probable causes of conflict; and to that end, they bethought themselves, among other things, of laying the foundations of a good understanding first between the riparians of the Rhine, and then between those of the other international rivers, "in order to facilitate the communication between nations and continually render them less strangers to each other."

Hitherto, the question of international rivers had obtruded itself only at intervals upon the notice of a few particular States; it was now, for the first time, subjected, in its whole extent, as an European coneern, to the negotiations of the Great Powers. 
44. ART. 5.

Such was, indeed, the object of Art. 5 of the Treaty of Paris, which ran:

"The navigation of the Rhine, from the point where it becomes narigable to the sea, and vice versâ, shall be froe, so that it ean be interdicted to no one:-and at the future Congress attention shall be paid to the establishment of the principles according to which the dues to be levied by the States bordering on the Rhine may be regulated in the mode the most impartial and the most farourable to the commerce of all nations.

"The future Congress, with a view to facilitating the communication between nations, and continually rendering them less strangers to each other, shall likewise examine and determine in what manner the above provisions can be extended to other rivers which, in their navigable course, separate or traverse different States."

The two sections correspond to two perfectly distinct ideas: the first indicates the bases of the understanding with regard to the Rhine; the second directs to inquire into, and settle, the means of extending the solution fixed upon to the other international rivers.

As to the bases of the understanding, they correspond to the probable causes of conflict which lie (1) in exclusions from navigation of the river; $(\mathcal{Z})$ in the fiseal policy of eertain States. In consequence, Art. 5 proclaims (1) that the navigation of the river shall be free and shall not be forbidden to anyone; $(\mathcal{Z})$ that the dues on navigation shall be regulated on the principle of strictest equality and in the mamner most favourablo to the commeree of all nations.

\section{4.j. Free navigation.}

What is the real scope of the clause concerning free navigation? Does it aim simply at the abolition of such monopolies as existed on certain parts of the river? Or does it intend to ensure the right of navigation to the subjects of the riparian 
States? Or, again, is its purpose to open the river indiscriminately to all flags?

The three interpretations have had their supporters; but the last, which is the right one, has met with lively opposition.

The perspicuous wording of Art. $\tilde{5}$ and unadulterated common sense should leave no doubt on the subject. A river flows through several countries. A. possesses the mouth; B. the middle course; C. the upper course which is still navigable. A. alone has aceess to the sea. To A. alone, the river is a complete economic instrument, for it pute him dircetly in communication with the whole world. As to B. and C., if they are redueed to using only that part of the river which flows through their own territory, they possess an instrument of no despicable national value perhaps, but of no value whatever as regards international relations.

We are not here concerned with the question whether or no A. possesses the right to monopolise the whole international oconomie adrantage which ean be derived from the river, and to exclude his co-riparians B. and C. from it. But it is erident that if $\mathrm{A}$. does so, he will draw down upon himself the jealousy and hatred of B. and C. Sooner or later conflicts will arise, which it would have been the interest of all three to prevent.

This is why the authors of Art. 5 have been led to proclaim that the navigation of the Rhine shall not be forbiden to anyone-a wide formula which is to be understood in its widest sense; for, in order to derive from an international river all the benefit which may legitimately be expeeted, all its riparians must not only have aceess to the sea, i.e. be able to send their own ships to, and receive them back from, all the ports of the world, but they must also be able direetly to reecive the goods which other nations carry on their own ships. In short, they must be able, as far as the river permits, to share in the traffic of the world. Therefore, international rivers must be open to all flags $(t)$.

t) The attitude of oversea nations on seeing their ships excluded from communication with the upper riparians of an international river inust also be taken into consideration. The interests of their international com- 


\section{Dues on navigation.}

But it is not enough to proclaim that the navigation of international rivers shall not be forbidden to anyone, it is also neessary to put an end to the fiscal extortions and discriminating treatment to which certain States may believe themselves entitled to resort. Principles must be established "according to which the dues to be levied hy the riparian States may bo regulated in the mode the most impartial and the most farourable to the commerce of all nations."

Such was the aspect of the problem when the Congress of Vienna opened.

\section{Proceedings of the Congress.}

47. The Commitese of Nivicition.

The working out of the solution was entrusted by the plenipotentiaries of the Congress to a Committee of Navigation (December 14th, 1814) which, having first to deal with the Rhine, was joined by delegates of all the riparian Powers of this river (February 2nd, 1815) (u).

merce and navigation are at stake. Hust we believe that they would for ever leave such interest; of theirs at the mercy of a State which, possessincr the mouth of the river, would be persistently churlish? The interests of oversea State: thu: combine with those of upper riparians to make freedom of navigation to all flags a necessity on international rivers. Cp. United States, attitud: with respect to the opening of the Amazon. Se. Soe Moore, Dig. I., p. 642.

(11) On December 1tth, 181t. Baron von flumboldt informed the plenipotentiaries of the eight Powers which had signed the Treaty of Paris, that he had consulted his fovernment (Prussia) and had no objection to joining a Committes charged with regulating the navigation of the Rhine. The Rnssian plenipotentiary then observed that it wonld be rnough if the Committer wee compo ed only of the plenipotentiaries of the Power which were most interested in the question: save that delegates of other interested Powers, like Holland, might he invited to join them. This suggestion was approved, and the (ommittee was formed, consisting of the Due de Dalberg (France), Baron von IIumboldt (Prussia), Lord Clancarty (Creat Britain), and Baron von Wessenberg (Austria) (Prot. 6). It the first sitting, having decided to deal with the Rhine first of all, they agreed to invite the plenipotentiaries of IIolland, Bavaria, Baden, Ilesse-Darmstadt and Nassan to take part in their Conferences. 


\section{THE BASIS OF DISCUSSION.}

At the first Conference the Due de Dalberg presented a project which faithfully reflected the intentions of the authors of Art. 5 of the Treaty of Paris, as we have described them. It was accepted as "the basis of discussion " at the second Conferenen (February 8th), but was so cut about that it had, as it were, ceased to exist by the end of the fifth Conference, when the Prussian plenipotentiary, Baron von Humboldt, ('ngaged to prepare a new draft.

\section{The Project of the Duc de Dalberci.}

An examination of the project of the Duc de Dalberg (see Klüber. III., 13-19 is none the less necessary. Under the inspiration of the Convention of 1804 -which, as regards commerce and navigation, created a sort of " communauté " between France and Germany on a section of the Rhine-he considered the whole navigable course of the river, with respect to eommerce and navigation, as common to the co-riparians.

"The Rhine," Art. 1 says, "from the point where it becomes navigable to the sea, shall be considered, in respect to commerce and navigation, as common between the States which it separates or traverses."

In the existence of this "communauté," the Duc de Dalberg saw the most effectual means of ensuring freedom of navigation and satisfactorily settling the fiscal question. He went on, Art. 2:

"The navigation (of the Rhine) in its whole course, either in ascending or descending, shall be entirely free and shall not be prohibited to anyone; due regard, howerer, being had to the regulations established with respect to its police, according to the mode which shall be settled."

This article does full justice to the first part of $\$ 1$ of Art. 5 of the Treaty of Paris. As to the second part tof this same section, the Due de Dalberg complies with its directions rather superficially as follows:

"Art. 3. The system adopted with respect to the police of the river and the collection of dues shall be 
uniform and the same on the whole course of the Rhine, and as far as prossible, of its branches and tributaries.

"Art. 4. The dues shall be collected in common, and the tariffs shall be invariable. . . ."

Then follow various provisions concerning the administrative body entrusted with the care of the "communaute" in matters relative to commerce and navigution: and, finally, provisions subjecting the tributaries of the Rhine to regulations based on the "system of uniformity of administration and police" applicable to the Rhine.

As to the other international rivers $x$, there are certain provisions concerning the principles to be adopted in the interest of the "general weal." some of them can be detected among the general maxims prockinued by Arts. 109 to 116 of the Final Act of the Congress of Vicnna.

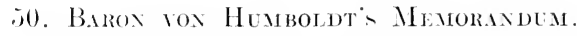

Inmediately after the presentation of the project of the Duc de Dalberg. Baron von Humbolelt read a memorandum preparatory to the work of the Commission. This memorandum is rery important. It considers the question at a different angle from the Duc de Dalberg's, and the ideas which are developed in it are those which finally prevailed in the Congress. It has been lavishly praised. It is exceedingly skilfully elaborated; but we cannot commend it unreservedly. While acknowledging that Art. j of the Treaty of Paris "is to be the basis of the work of the Commission," Baron ron Humboldt suggests that it is first of all necessary to consider "the principles which the general interest of commerce makes it expedient to adopt." This he makes his starting point; from this point of view he makes his recommendations. The consequence is that, owing to the connection which exists between navigation and the general interest of commerce, the way is admirably prepared for a confusion which-as we shall see

(x) The Duc de Dalberg quoted the Weser, the Oder, the Vistula, the Danube, the Pô and the Tagus. The Weser, the Oder and the Pô are no longer international rivers (see Appendix I). 
further on-has made it possible to distort the true scope and meaning of Art. 5 while preserving its essential terms ( $5 \tilde{5})$. Having thus, so to say, substituted the principle of the general interest of commerce for Art. 5) of the Treaty of Paris, Baron ron Humboldt, in order to reconcile the general interest of commerec with the interests of the riparian states. proceeds to reject the consequences of his principle unless the three following conditions are complied with: (1) that they should be agreed upon by the common consent of all the ripariank: $(\mathcal{\sim})$ "that no riparian State should be disturbed in the exercise of its rights of sovereignty $(y)$, in respect to commerce and navigation, beyond the stipulation of this convention;

(3) that every riparian State "should be entitled to its shure of the dues collected on navigation in proportion to the extent: of its territory along the banks of the river."

Under these three conditions. Baron ron Humboldt deenss it possible to assent to:

(1) freedom of navigation $(z)$ :

(2) the abolition of staple duties (droits d'itape:

(3) a uniform tariff of the dues to be collected;

(4) the reduction of the number of offices for their collection;

(5) the absolute separation of the collection of customs duties and of navigation dues:

(6) the appropriation of the receipts of dues to the works necessary to navigation ( $a$ )-these being quite distinct from the works for the preservation of the country from inundation. The necessary precautions are to be taken in order that these double works should be undertaken on the same system so as not to interfere with each other:

(7) the unification of the police regulations;

(8) mutual engagements to provide. as far as possible, for

(y) Cp. $\$ \$ 17,18,20$.

(z) The author of the Memorandum abstains from adding, in compliance with the directions of Art. 5, that free navigation shall not be forbidden to anyone.

(a) The residue to be distributed among the riparian States in proportion to the extent of their territory along the banks of the river. See above, Condition 3 . 
the inaintenance of free navigation even in case of war between the riparian States.

Most of these principles, Baron ron Humboldt observes, are to be found in the Convention of 1804 " a very good piece of work, the utility of which has been proved by experience" to which the Commission would do well to refer, though in a now examination of it, it would be necessary to take into consideration:

(1) the territorial changes which have occurred since 1804 ;

$(2)$ the points which will become private concerns of the Germanie Confederation (such. e.g., as the annuities secured on navigation dues);

(3) the local necessities.

Finally, Baron ron Humboldt examines the means of extending these provisions to all international rivers ( $\$ 66$ ).

Baron von Humboldt's memorandum is a real explanatory introduction to the decisions of the Congress.

\section{Otheli Memoranda.}

The Duteh plenipotentiary too, Baron ran der spaen, stated in writing a few observations concerning forced harbour duties (relache forcée) at Mayence and Cologne; the distinction to be made between lesser and greater navigation and various other points of the Convention of 1804 , which he thought ought to be carefully considered, and on which he begged the Committee to hear the "General Director of the Rhine tolls" -which was done.

On the other hand, some Rhenish towns, threatened in their privileges, applied for permission to defend their interests.

Thus the Committee of Navigation saw their task hecome increasingly difficult and intricate. These unforeseen complications served, to a large extent, to obscure the elear directions of Art. 5 .

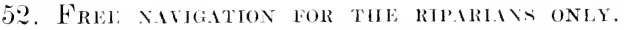

As the result, instead of elearly proclaiming the opening of the Rhine to all flags, the Commission elaborated an ambiguous text which, with the help of a few appropriate restrictions 
inserted in the regulations which were afterwards made by the delegates of the riparian States, made it possible to confine the free navigation of the Rhine to ships bolonging to subjects of the riparian States and navigated by a captain possessing a licence which could be granted only to riparian subjects. (See $\$ 82$, on the Regulation of Mayence, 1831.)

But we anticipate. We must now bestow some attention upon the discussions whieh led to the final deeision of the Committec in this matter.

\section{Lord Clancarty's amendment.}

In his menorandum, Baron von Humboldt declared that the navigation must be free, but, as we have pointed out, abstained from reproducing the words of Art. j: "de telle sorte qu'elle ne puisse etre interdite à personne." This omission may, we believe, be taken to represent Prussia's sentiments on the question.

As we have seen, the Duc de Dalberg reproduced the omitted words in his project. But Lord Clanearty, deeming this insufficient, insisted on the necessity of a still more explieit wording. He proposed to say:

"The Rhine, from the point where it becomes navigable to the sea and vice versâ, shall be entirely free to the eommerce and navigation of all nations . . . ." $(b)$.

Lord Clancarty's amendment was an emphatic statement of the sound interpretation of Art. 5. It removed all possible ambiguity. This is probably the reason why it was doomed in the eyes of the Rhenish delegates, who, we presume, perceived in the confusion adumbrated in Baron ron Humboldt's memorandum, a means of preserving many privileges and of neducing to a minimum the concessions to be made to the general interest.

(b) "Le Rhin, du point où il devient navigable jusqu'à la mer et réciproquement, sera entièrement libre au commerce ct à la navigation de toutes les nations de manière que, dans tout son cours, soit en remontant, soit on descendant, il ne puisse, 'sous ces deux rappoits, être interdit ì personne, en se eonformant toutefois aux réglements qui seront établis pour la police, d'après le mode eonveuu, lesquels réglements seront égaux pour tous ot les plus favorables au commerce de tontes les nations." 
Howerer, in the protocols, we find no trace of direct opposition to the ideas of Lord Clanearty. The Commission proceeded with the exannination of the project of the Due de Dalberg, until it became clear that an entirely new draft must be made. On the 24th February, Baron ron Humboldt assumed the task, and on the 28th he presented a draft which he proposed to substitute for the first sixteen articles of the project of the Due de Dalberg. His wording of the article conecrning free navigation was as follows:

"The navigation of the Rhine along its whole course from the point where it becomes navigable to the sea, either in descending or ascending, shall be entirely free, and shall not, in respect of commerce, be prohibited to anyone; due regard, however, being had to the regulations ostablished with respect to its poliee, which regulations shall be alike for all, and as farourable as possible to the commeree of all nations."

Baror von Humboldt had seized his opportunity. Let us recall to our mind his memorandum where he subordinated the principle of free navigation to the general interest of commerce. Instead of considering the question, like Lord Clanearty from the double point of riew of commeree and navigation $(c)$, he stuck to his formula, and thus, while reproducing the words of Art. 5, obliterated their meaning by means of the interpolation: "sous le rapport du commerce."

Lord Clancarty protested against this restriction. But it suited the delegates of the Rhenish States, who approved of it. And we read in the protocol of the ith Conferene (Mareh 3rd):

"The other articles of the said project were then examined. And concerning Art. 1, Lord Clancarty proposed, as an amendment, to substitute. for Baron ron Humboldt's wording, the wording which he had formerly proposed and which was inserted in the protoeol of the

(c) It the Conference of Berlin, 1885, the plenipotentiaries quite rightly dealt with the question of commereial freedom and that of free navigation separately-the latter being a corollary and a necessary complement of the former (see $\$ \$ 182,192$, and note). 
second Conference, alleging that, to the provision that. the navigation shall not be forbidden to anyone, Baron ron Humboldt's wording adds the restriction: 'sous le rapport du commerce,' which does not seem to correspond with the intentions of the Peace of Paris which declaren that the navigation shall not be forbidden to anrone.

"Nerertheless, the other members of the Commission were of opinion that there were no grounds for making this amendment, since the wording of Baron ron Humbolut did not seem to be far remored from the arrangenrents of the Treaty of Paris ("'u que la réduction de M. Ie Barom de Humboldt ne semble pas s'éloigner des dispositions du Traité de Paris'), which had for their object merely the preservation of the navigation from such impediments as a conflict between the riparian States could bring about, and not the granting to all the subjects of non-riparian States an equal right of narigation with that enjored by the subjects of the riparian States and in return for which there would be no reciprocity" $(d)$.

(d) Indeed, the peace-makers who drafted Art. 5 of the Treaty of Paris, 1814, aimed at removing the causes of conflicts between the riparian States of the Rhine. Their object was the same as regards the Seheldt. This is why a secret clanse was added to the Treaty of 1814. But, to assert that they had no intention of opening international rivers to all flag: is simply to run counter to the very terms of the article. If they had intended to open the Rhine only to the subjest of the riparian States, they would not have written: "The navigation of the Rhine... shall be free, and shall not be forbidden to anyone....", and they would not have recommended to extend this provision to all international rivers, with a view, as they declared in Art. 5, to "facilitating the communication. between nations, and continually rendering them less strangers to one another" (see, besides, $\$ \S 44$ and 45, dealing with Art. 5).

To know what degree of authority this interpretation of Art. 5 possesses. one must remember (1), the composition of the Conmission (sec note. $\S 47)$; (2) the fact that out of the four delegates of the Congress, two, the British and the French, strongly opposed it.

If, however, at the beginning of the Congress both the British and the French plenipotentiaries claimed free navigation for all flags, the insistence of the French plenipotentiary soon became gradually less. His attitude requires an explanation, which we find in an extract from the instructions issued in September, 1814, by Louis XVIII. to his embassy to the Congress of Vienna: "With regard to the dues on the narigation 
Unfortunately, this decision taken by diplomatists who, at the time. thought of nothing but the Rhine, was to be the basis of Art. 109 of the Final Act of the Congress of Vienna, applicabl. to all international rivers.

\section{Other Questions.}

(a) Even at the second sitting of the Committee (February 8th), Prussia declared that she could not assent to the principle of collecting dues in common as it was organised by the Convention of 1804 . In consequence it became impossible to provide the river with such a common administration as the Duc de Dalberg had proposed. Baron ron Berkheim, the plenipotentiary of Baden, explained in a note annexed to the protocol of the third Conference (February 20th) that it was no longer necessary, "since all the riparian States are interested in the same object, namely, that of co-operating, as far as possible, to give commerce and the navigation of the Rhine all imaginable latituke." It was, however, acknowledged that, in order to give uniformity to this co-operation, a central Commission with the help of a few inspectors might be useful (Vth Conference, February 2tth). So the idea of a community was not entirely rejected.

(b) In spite of the efforts of the towns interested in their continuance, it was decided that forced harbour duties should be abolished.

(c) It was also decided that the Leck alone should be deemed the prolongation of the Rhine in Dutch territory, and subjected to the provisions applicable to the Rhine. See $\S 81$, for the details of the controversy concerning the mouths of the Rhine and access to the sea.

of the Rhine and the Scheldt, since they must be the same for all, France has nothing to desire, except that they be very moderate. As to the free navigatiou of the Rhine and the Scheldt, it will give France the same advantages-without the burdens attaching to it-which the possession she has renounced, of the countries traversed by these rivers would have given her. She cannot therefore reasonably regret such possession." The formula adopted by the Congress gave satisfaction to France. Her representative, accordingly, was contented with it. 


\section{Regulations of the Rhine.}

Finally, the Committee adopted, after slight alterations of wording, the articles concerning the navigation of the Rhine presented by Baron von Humboldt.

\section{Thi navigation of the Rhine.}

We need not deal further with the article concerning the right of navigation (V., $§ 52-53$ ).

With regard to the other points, it 'will be interesting to compare Baron von Humboldt's suggestions in his memorandum with the solutions adopted in the thirty-two articles of 1815 concerning the navigation of the Rhine-which we shall here call the regulations.

56.-I. Navigation dues and Police of the River.

Art. 5 of the Treaty of Paris required that dues should be regulated "in the manner the most impartial and the most favourable to the commerce of all nations."

Baron von Humboldt says: "It is absolutely necessary to regulate these dues in thoir totality from the point where the river becomes navigable to its mouth, in a fixed, uniform and invariable manner, subject to a periodical revision of the tariff (if it should be thought necessary) by all the riparian States, after the lapse of a certain number of years. It is also necessary that the rate of duties should be sufficiently independent of the particular quality of the goods, to avoid the inconvenience of detaining the vessel on its passage in order to make a detailed examination of the cargo. As to the kind of dues (la qualité du péage), it will be necessary to see whether it is possible to establish a principle sufficiently general to be easily applied everywhere in order to fix at least a maximum." And further, speaking of the regulations of police, he urges the necessity of their being "uniform and established by common consent, so that they cannot be changed by any one riparian State alone; but so that they do not interfere with the police which the riparian States may exercise upon rivers by virtue of their 
rights of sovereignty, without interfering "with the freaton of navigation."

We turn to the regulations:

By Art. 2: "The system to be adopted for the wollection of dues, as well as the maintenance of the police, shall bo the same throughout the whole course of the river, and shall extend, as far as circumstances may permit, to those of its branches and tributaries ('embranehements et confluents') which, in their navigable course, separate or traverse different States.'

By Art. 3, a minimum is fixed; the price to be paid bein. proportionate to the weight of the goods, with possible alterations in favour of agriculture and the supply of the wants of the riparian inhabitants. The elaboration of the new tariff is entrusted to the Commission charged with the framing of the definitive detailed regulations.

By Art. 4: "The tariff thus settled shall not be increased except, by common consent, and the riparian Governments of the Rhine, adopting as a principle that their true interest consists in encouraging the commerce of their States, and that the duas on navigation should ehiefly be appropriated to defraying the expenses of its preservation $(e)$, formally engage not to inerease the same except for the most just and urgent reasons, nor to impose any other dues whatever on navigation, in addition to those fixed by the present regulations, under any denomination or pretext whatsoever."

\section{7.-II. Collection and distribution of dues.}

With respect to the number of offices for the collection of dues, Baron von Humboldt says: "As nothing is so injurious

(e) We read in Protocol VII., § 5, ad Art. 4: 'Lord Clancarty proposed that instead of saying: "que les droits de navigation sont principalement destinés à oouvrir los frais de son entretien," it would be preferable to insert the principle: "que ces droits ne pourraient être considérés comme une source do revent direct." But all the members of the Committee agreed that this princip'e could not be put forward, and Baron von Humboldt particularly observed that this stipulation was "trop précise" for the Powers to consent to have their hands tied by it. In consequence Lord Clancarty did not insist any more on obtaining a vote on his amendment (à passer aux voix sur l'amendement proposé).' 
to navigation as to be compelled frequently to touch at intermediate points for the purpose of paying dues, the attention of the Committee should, above all, be directed to the object of diminishing the number of these offices." And further oll, he recommends "the appropriation of the receipts of the dues to the necessary works, and the distribution of the residue among the riparian States in proportion to the extent of their territory along the banks of the river."

By Art. 5 of the regulations: "There shall be only twelve offices for the collection of dues, throughout the whole extent of the Rhine between Strasburg and the Dutch frontier" and a proportionate number from Strasburg to Basle and in the Netherlands.

Art. 46 of the Convention of 1804 acknowledged the existence of twelve offices $(f)$. A unified administration would easily have made a reduction of this number possible, but such at. system was, as we have seen, opposed by Prussia as incompatible with the principle of sovereignty. The same solicitude for the sovereignty of the riparians is noticeable in the next. provisions:

By Art. 6: "Each riparian State shall collect the dues on its own account and by its own collectors; the whole of the proceeds being distributed in proportion to the extent of the respective possessions of the different States on the bank." The procedure shall be uniform.

This being so, it is but a natural consequenee that "each State of the Rhine shall be at the expense of keeping in good repair the towing-paths which pass through its territory, and of maintaining the necessary works throughout the same extent in the channel of the river, in order that no obstacle may be experienced by navigation" (Art. 7).

\section{8.-III. Courts of Justice.}

The system of a common administration being rejected, its corollary the system established in 1804 for the settlement of disputes relative to navigation had, of course, to disappear. 
In consequence the regulations provide by Art. 8 that a judicial authority of "first instance," paid by the State in the name of whose sovereign it pronounces judgment, shall be attached to each office for the collection of dues. The procedure is to be uniform.

By Art. 9, each State has to establish a tribunal of "second instance." Appeals may be brought either to the Central Commission or to the superior tribunal of the country whose Court of "first instance" was seized with the case. No further appeal is allowed.

\section{9.--IV. Central Commission.}

Unity and uniformity are to be preserved by the establishment of a Central Commission conıposed of delegates from the riparian Powers, and sitting once, possibly twice, a year (Arts. 10-11).

This Central Commission exercises a kind of general supervision; " they shall at the same time attend to all matters that may contribute to the general interests of navigation and commerce, and shall publish, at the close of every year," a detailed report of the state of the navigation of the Rhine, its annual movement, its progress, the changes which may take place, and every thing relating to internal and foreign commerce (Art. 16).

The Central Commission decides by an absolute majority of votes; "but as its members must be considered as agents of the riparian States, charged with making arrangements for their common interests, their decișions shall not be binding upon these States until their consent shall have been given by their commissioners" (Art. 17).

As a permanent authority, in the absence of the Central Commission, Art. 12 provides that there shall be named a chief inspector and three sub-inspectors, the appointment of whont is regulated by Arts. 13 and 14, together with questions relative to their pensions and trial by court of justice.

According to Art. 15, their duties are: "to see to the execution of the regulations, and to organise (mettre de l'ensemble dans) everything relating to the police of the navigation." . . . 
They must furnish the Central Commission with an account of their proceedings (Art. 16); and the chief inspector must collect "all information that may be necessary for the Central Commission regarding the state and defects of navigation, and must suggest to them such measures as he may consider advisable to adopt."

Their salary is to be paid jointly by all the riparian States, which have to contribute " in proportion to the part which they take in their appointment" (Art. 18).

60.-V. SUPPRESSION OF CERTAIN DULS AND OF ALL MONOPOLIES.

Baron von Humboldt points out the necessity of regulating "the duties of staple (d'étape) where they exist, since nobody would think of establishing new duties of this nature."

Art. 19 provides that "staple duties having been suppressed by Art. 8 of the Convention of the 15th August, 1804, that suppression is hereby extended to the dues which the towns of Mayence and Cologne used to levy under the denomination of harbour and port dues, or breaking bulk (Umschlag), so that one shall be at liberty to navigate along the whole course of the Rhine, from the point where it becomes navigable to that where it falls into the sea, either in going up or down the river, withont being compelled to break bulk, or to remove the cargoes into another vessel, in any port, town or place. whatever."

And by Art. 21: "No company, much less any qualified. boatman (in places where there are no companies) shall, in any of the riparian States. exercise any exclusive right of navigation on the river or on any part of it. . . ."

\section{1.-VI. Dues anmiteded Separation from Customs.}

Art. 20 provides for the uniform regulation of crane, quay. and warehouse dues, "in places where such accommodations exist, or where they may hereafter be established."

Art. 24 prohibits the farming out, either wholly or partially, of the dues on navigation; and Art. 29 provides that no demand for exemption from, or for an abatement of, these dues shall be admitted in any case whatever. 
Art. 22 complies with Baron von Humboldt's requirement of "an absolute separation of the collection of customs duties from that of navigation dues, and the necessary precautions to prevent the right of the riparian States to establish custom houses, from interfering with navigation.'

As a distinctive sign, the boats in the service of the tolls (octroi) will have "Rhenus" inscribed on the flag of their State (Art. 23).

\section{2.-Vil. Neutr.latit in the event of war.}

In his memorandum. Baron von Humboldt mentions the necessity of "mutual engagements to provide, as far as possible, for the maintenance of free narigation, eren in case of war between the riparian States."

Art. 26 says: "If it should happen (which Grod forbid) that war should break out among any of the States of the Rhine, the collection of the tolls shall continue uninterrupted, without any obstacle being thrown in the way by either party. The boats and officials in the service of the tolls (octroi) shall enjoy all the privileges of neutrality. Guards shall be prorided for (il sera accordé des sauregardes) the offices and safes belonging to the tolls (octroi)."

This is a reproduction of Art. 131 of the Conrention of 1804 $(\$ 42)$ : but it must be noted how the rejection of the common administration of $180+$ narrows the scope of the article:

63.-Vili. Permanext annuities secured on the proceens OF THE TOLLS (RENTES PERPÉTUELLES ISSIGNÉES SUR LE PRODUIT DE L'OCTROI).

These are dealt with in Art. 28 , while Arts. 29 to 30 deal with pensions.

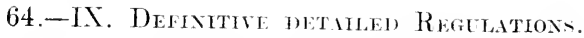

Art. 31 prorides for the formation of the Central Commission, and Art. 32 mentions among its duties:

the drawing up of regulations for the navigation of the Rhine. under the guidance of the present articles, and 
to be approved by the riparian governments. Not until this is done is the new order of things to commence.

In connection with these detailed regulations, Art. 27 says: "The existing Committee has been obliged to confine itself to establishing very general principles, without entering into all the details which it will be necessary to regulate. In consequence it is left to the definitive regulations to determine on all particular provisions, namely, those concerning: the tariff of dues on merchandise in general, as well as on goods which, according to a certain classification, pay smaller dues; the situation of the offices for the collection of dues, their internal management and the mode of eollection; the organisation of the judicial authorities of the first and second instance, and the procedure; the preservation of the towing-paths and of the works in the bed of the river; the manifests; the gauging (jaugeage), and the designation of boats and timber floats; the weights, measures, and kind of money to be used, and their ratios and valuation (réduction et évaluation); the police of the ports for shipping, unloading or shifting cargoes; the companies of watermen; the requisite qualifications for watermen; the greater or lesser navigation, if such a distinction, which no longer exists in the sense given to it by the Convention of 1804 , should be maintained under other circumstances and for other reasons; the scale of charges for freight; contraventions; the separation of offices for the navigation from the eustomhouses, \&c., \&c.

65. Special Articles concerning the Nechar, thr Main, the Moselle, the Meuse and the Scheldt.

Finally, the Committee, taking into consideration the local accidents and circumstances peculiar to the Neckar, the Main, the Moselle, the Meuse, agreed upon certain special provisions concerning them, into the details of which it is unnecessary to go.

Wo may, however, mention that "freedom of navigation" such as has been determined for the Rhine, is, by Art. 1, extended to those rivers and to the Scheldt. This latter measure 
was in execution of a secret Art. (3) of the Treaty of Paris, 1814, which ran:

"The freedom of the navigation of the Scheldt shall be established upon the same principle which regulates the navigation of the Rhine in the 5th Article of the present treaty."

The wording adopted by the Committee of Navigation for the Scheldt is:

"Art. 7.-Everything relating to the navigation of the Scheldt which may need subsequent arrangement, besides the freedom of navigation on this river specified in Art. 1, shall be definitively regulated in the manner the most favourable to commerce and navigation, and the most analogous to the regulations established on the Rhine."

\section{Regulations for other rivers.}

66. Baron von Humboldt's opinion.

The first part of the task of the Committee of Navigation. being achieved, it remained to find the means of extending to other rivers the decisions which had been reached. Here, again. Baron von Humboldt's memorandum throws light on the ideawhich prevailed at the Congress: "It would be found impossible to conclude similar conventions applicable to the other great European rivers during the sitting of the Congress. However, a considerable advance might be made towards the general freedom of river navigation, by inviting the Powers who should sign the Final Act of the Congress to pledge themselves to conclude with each other, and with other Powers, arrangements respecting the freedom of navigation of those rivers within their territories which are common to other States, in the same manner as it is the usage to stipulate in treaties of peace for the conclusion of treaties of eommerce. In order to obviate the vagueness which might render this pledge illusory, the Powers should also be invited to declare, in a positive and obligatory manner, that the general principles before stated (Nos. 1-8, \$50) should form the basis of the arrangements 
to be thus concluded. Thus far, and no farther, to my mind, the Committee may go. To overstep these limits and attempt greater modifications of the principles would involve the risk of achieving nothing at all."

The Committee followed Baron von Humboldt's advice, and thus were brought into being the nine articles inserted in the Final Act of the Congress, under numbers 108 to 116 .

67. The Powers engage to regulate navigation by common CONSENT.

"Art. 108.-The Powers whose territories are separated or traversed by the same navigable river, engage to regulate, by common consent, everything regarding its navigation. For this purpose, they will name commissioners, who shall assemble at latest six months after the termination of the Congress, and who shall adopt, as the bases of their proceedings, the following principles."

68. Freedom of Navigation.

"Art. 109.-The navigation of the rivers referred to in the preceding article, along their whole course, from the point where each of them becomes navigable, to its mouth, shall be entirely free, and shall not, as far as commerce is concerned, be prohibited to anyone; due regard, however, being had to the regulations to be established with respect to its police; which regulations shall be alike for all and as favourable as possible to the oommerce of all nations."

69. Uniformity. Dues. Police.

"Art. 110.--The system which shall be established, both for the collection of dues and for the maintenance of police, shall be, as far as possible, the same along the whole course of the river; and shall also extend, unless particular circumstances prevent it, to those of its branches and tributaries (embranchements et confluents) which, in their navigable course, separate or traverse different States." 
70. TARIFF.

"Art. 111.-The dues on navigation shall be regulated in a uniform and invariable manner, and with as little reference as possible to the different quality of the mer- . chandise, in order that a minute examination of the cargo may be rendered umnecessary, except with a riew to prerenting fraud and evasion. The amount of these dues, which shall not in any case exceed those now paid, shall be determined by local circumstances, which scarcely allow of a general rule in this respect. The tariff shall, however, be drawn up with a view to encouraging commerce by facilitating navigation, and the existing tolls of the Rhine may serve as a guide (norme approximative).

"The tariff, once settled, shall not be increased, except by the common consent of the riparian States; nor shall the navigation be burdened with any other ducs than those fixed in the regulation."

71. OFFHE FOR THE COLLECTION OF DUES.

"Art. 112.-The offices for the collection of dues, the number of which shall be reduced as much as possible, shall be settled in the regulations: and no change shall afterwards be made except by common consent, unless one of the riparian states should wish to diminish the number of those which exclusively belong to it."

72. TOWING-PATHS IND WORKS.

"Art. 113.-Each riparian State shall be at the expense of keeping in good repair the towing-paths which pass through its territory, and of maintaining the necessary works throughout the same extent in the bed of the river, in order that no obstacle may be experienced by navigation.

"The regulations shall determine the manner in which the riparian States shall participate in these latter works, where the opposite banks belong to different governments." 
73. HaRbour DUES, ETC. . .

"Art. 114.-There shall nowhere be established staple duties or port or forced harbour dues (droits d'étape, d'échelle ou de relâche foreée). Those already existing shall be preserved only as far as the riparian States (without regard to the local interest of the plaee or of the eountry where they are establishel) shall find them necessary or useful to navigation and commerce in general."

74. Customs.

"Art. 115.-The customs of the riparian states shall have nothing in common with the dues on navigation. Regulations shall be established to prevent officers of the customs, in the exereise of their functions, from throwing: obstacles in the way of navigation; but eare shall be taken, by means of a strict police on the bank, to preclude every. attempt of the inhabitants to smuggle goods with the help o: boatmen."

75. Regllation.

"Art. 116.-Everything indicated in the preceding articles shall be settled by a common regulation, which shall also comprise whatever may need subsequent determination.

"The regulation once made shall not be altered, except with the consent of all the riparian States; and these shall take care to proride for its exeeution with due regard to circumstances and locality."

76. THE FINAL vote.

At the twelfth Conference, on March 24 th, the decisions of the Committee were definitively approved; viz., the general principles embodied in Arts. 108 to 116 of the Final Act of the Congress: a report concerning the port of Antwerp $(g)$; the

(g) This Report deals with the means of transforming Antwerp into a purely commercial port. Napoleon had turned it into a vast naval arsenal which, in July, 1809, Great Britain had, in vain, endeavoured to destroy. 
thirty-two articles concerning the Rhine, and, finally, the seven articles concerning the Neckar, the Main, the Moselle. the Meuse, and the Scheldt. The task of the Committee was accomplished.

\section{The Final Act of the Congress of Vienna.}

It remained only for the Congress to sanction the work of the Committee of Navigation. As, regards the general principles, it was done quite naturally by their being embodied in the Final Act.

As regards the two regulations, it was decided that they should have "la même force et valeur" as if they had been inserted in the general treaty (Arts. 117 and 118).

Finally, by Art. 119, the Congress solemnly invited all the Powers represented, as well as the Princes and free towns who had taken part in the arrangement, to adhere to them.

But this is not all: A treaty of May 23rd, 1815, between Russia and Austria applied, by its Arts. 24 to 29, the principle of free narigation to the rivers and canals within the territory of ancient Poland (as it existed before 1772); and a treaty of the same date between Russia and Prussia did the same (Arts. 22-29). (See Appendix I.)

In its Art. 14, the Final Act of the Congress proclaims that these principles "shall be invariably upheld," and, in Art. 96, it ordains the application of the general principles

Despite the capture of Flushing, the Earl of Chatham had been obliged to abandon Zealand. Napoleon then still further increased the military importance of the place. But, when the Allies captured the Dutch and Belgian provinces, Antwerp was oceupied by British and Prussian troops. The Cabinet in London delared that they wanted: "(1) commereial freedom on the Scheldt; (2) the destruction of the naval arsenal. The peace of Paris, May 30th, 1814, stipulated for both. On August 24th, 1814, the Allios and the Government of Louis XVIII. divided the fleet between themselve;, and the demolition of the works had begun when, on Mareh 22nd. 1815, at the Congress of Vienua, the Committoe of Navigation drew up this Report. Though the Powers wished Antwerp to be no longer an exelusively military port, they did not want to deprive it of all means of defence. When the Belgian Government ehose Antwerp as "réduit national," the British Government approved, and no objection was raised by either Fran'e or Ifolland (V. Nyz, Droit Internat. II., 149). 
adopted by the Congress, to the Pô, which afterwards became a national river.

\section{Applications of the principles of the Congress of Vienna.}

78. Thr three stages.

In $\S 30$, we have stated reasons which make it possible to limit to a relatively small number of rivers an inquiry into the applications and modifications of the principles of the Congress of Vienna.

Even confining one's attention to the Rhine, the Danube and the Congo, one plainly perceives three distinct stages in the development of the principles: the first characterised by the régime of the Rhine; the second, introduced on the Danube by the Treaty of Paris, 1856; the third, being the result of the discussions of fourteen Powers assembled in Berlin, in 1885 , to regulate the navigation of the Congo.

\section{The interpretation of Art. 109.}

It will be seen that most of the ensuing discussions have arisen from a fundamental divergency in the interpretation of Art. 109 of the Final Act of Vienna. While some Powers. like Great Britain and France insist on a liberal interpretation. others, like Austria and Germany, uphold a restrictive one. The text of the article, ambiguous as it is, does not conclusively support either view. But whereas the restrictive interpretation is basel only on the passage of Prot. 7 quoted in $\S 53$, the liberal one rests on the clear text of Art. 5 of the Treaty of Paris, 1814, which was the basis for the decisions of Congress. The question is important: from the interpretation adopted depends whether or no the ships of non-riparian States are entitled to the same treatment as those of the riparian Powers In subsequent regulations, both interpretations are illustrated: the restrictive one on the Rhine for instance; the liberal one on the Scheldt and the Pô. At any rate, there is no doubt that the liberal interpretation has gained considerable ground ever since 1815. The Treaty of Paris, 1856, and that of Berlin, 
1885, show it clearly, as does also a comparison between the more receni regulations for the Rhine and the older ones.

In $§ \S 135$ and 137 will be found an account of the most important diseussion which has taken place between the upholders of the two interpretations.

In whatever manner we interpret it, we must note that Art. 109 does not proclaim a right of all flags to the free navigation of international rivers. But the Congress expressly invited the Governments to adhere to, and apply, the principles recently elaborated, and though they have met with occasional ill-will and resistance, the principles have obtained the adhesion of most States.

\section{The Rhine.}

80. The definitive Regulation of the Ripariax ConMISSION.

We have seen that by Art. 32, the Vienna Regulations for the navigation of the Rhine entrusted a riparian Commission with the framing of a definitive and detailed regulation conformable to the principles adopted by the Congress. The article proceeded:

"When the regulation is completed, it shall be submitted to the Governments of the Rhine for their approbation, and until such approbation shall have been given, the new order of things shall not commence, nor shall the

Central Commission enter upon its regular duties."

The Duteh Government, with which, apparently, the new principles were not in favour, created difficulties, so that no agreement could be reached until 1831. Not until then was the "new order of things" definitively established on the navigable course of the Rhine. See Art. 31 for the interim conditions.

\section{Controversy with Holinand.}

To understand this controversy, one must observe:

(1) That Art. 1 of the Vienna Regulations says: "The navigation, along the whole course of the Rhine from the point where it becomes navigable 'jusqu'à $l \boldsymbol{a}$ 
mer". . ." This, the Dutch contended, did not mean "jusque dans la mer."

(2) That in Dutch territory, the Rhine flows in several branches which confound their waters with those of the Meuse.

At the eighth sitting of the Committee of Vienna, it was agreed "that the Leck should alone be considered as a continuation of the Rhine and be subjected to the provisions to be applied to that river." However, Holland maintained that her right of sovereignty "on the sea bounding her territory, even where its waters are mixed with those of the Rhine" remained unaffected (V. Preamble of Convention of Mayence, March 31st, 1831, State Papers, vol. 18, p. 1076). The other riparian States protested against such a claim. They contended that under the name "Rhine" the Congress of Vienna had "comprised the whole course of the river, with all its braniches and mouths in the Netherlands, without distinction" (see ibid.). Holland upheld her views pertinaciously, and it was not until after the Belgian Revolution that an agreement became possible. Holland continued to reserve her rights, but consented that the Leck and the Waal be considered as the continuation of the Rhine in the Netherlands. In consequence. she adhered to the Regulation of Mayence, and by Art. :3. undertook to open other channels to navigation in case the two above mentioned should accidentally cease to give access to the sea $(h)$.

\section{The Regulation of Mayence, March 31st, $18: 31$.}

Apart from a modification of wording (in fine), the regulation sets out with reproducing Art. 1 of the Vienna Regulations (with the words: "jusqu'à la mer"). (See § 53.)

Art. 2 recites that "H.M. the King of the Netherland. consents to the Leck and the branch called Waal being con-

(h) It is interesting to note that the first controversy arising from the application of the principles of the Vienna Congress turns on the question of access to the sea. It shows that there, in fact, is the fundamental point of our problem, the definitive solution of which will only be reached by the complete opening of all international rivers to the navigation of all flags. 
sidered as the continuation of the Rhine in the kingdiom of the Netherlands" ( $i)$.

A complete analysis of the regulation is unnecessary, aspecially as it has been replaced by the later Regulation of Mannheim. It suffices to refer to a few of the 109 articles which compose this lengthy and ponderous regulation.

Art. 3 begins:

"Vessels belonging to subjects of the riparian States anci belonging to the navigation of the Rhine, shall not be obliged to tranship (transborder) or break bulk when passing from the Rhine to the high seas and vice versa through the kingdom of the Netherlands."

Notc that this favour is granted only to vessels (a) owned by subjects of the riparian States; (b) belonging to the navigation of the Rhine.

Now, what is this "navigation of the Rhine"? The last section of Art. 3 explains:

"Shall be considered as belonging to the navigation of the Rhine, in the sense of this regulation, all vessels whose masters or captains (patrons ou conducteurs) shall br: provided with the licence prescribed by Art. 42 . . ."

When then one turns to Art. 42 which dwells on the necesssity for having long experience in order to navigate the Rhine, and on the necessity for making sure of the capacity of the persons to whom the exercise of the navigation of the Rhine is entrusted, one reads at the end:

"The licenees of navigation in question shall not be granted, except to recognised subjects of the riparian

(i) Already in 1826, the King of the Netherlands, "not wishing to prevent the others any longer from enjoying the stipulations of the Congress," ordained in a Derree of September 10th, "that the Leck be considered as the continuation of the Rhine in the territory of the Netherlands, and that the tolls (péage;) be replaced by a navigation due. . . ." And six months later he issued another decree regulating the execution of the first decion (March 1st, 1827). These were the first steps towards the agreement.

One of the reasons given by Holland for refusing to "consider" the Leck as the eontinuation of the Rhine, was that this branch of the river had been reudered navigable only by important and costly works. 
States of the Rhine; and the ressels shall be mentioned in the licences."

Thus, not only must the vessel be the property of riparian subjects. but it can be navigated only by riparian subjects.

We have here a typical example of a regulation proclaiming a liberal principle in its first article, and whittling it down in subsequent articles. A French writer (Ed. Engelhardt) has remarked, perhaps not without reason, that the Regulation of Mayence is " une traduction vivante de l'idée de Humboldt."

Another section of Art. 3 indicates what channels put the river in direct communication with the high sea, with regard to the sea-going vessels belonging to the navigation of the Rhine.

The next articles deal with the eargoes, which; though free from transit duty, are subject to a fixed duty.

The foregoing provisions, Art. 7 expressly states, do not in any way prejudice "the maritime tonnage dues, the lighting, pilotage and other dues of the same kind, which every sea-going vessel is liable to pay when proceeding from the sea to the Netherlands and vice versâ." However, Art. 12 provides that all sea-going vessels belonging to the Rhine shall be on exactly the same footing as Dutch vessels with regard to the payment and tariff of the dues above mentioned. This is what is called the "system of assimilation " by which the Netherlands preserve in this case complete freedom in the exercise of their right of fixing the dues to be levied on navigation within their own territory.

Thus much concerning the question of access to the sea.

With regard to the fluvial navigation, a navigation due including a "reconnaissance" due based on the tonnage of the boat and a duty to be paid for every quintal ( 50 kilogs.) of eargo, and calculated according to the distance, is levied by each riparian State (cp. § 39).

Boats are to be visited yearly by an expert, and pilots must be taken on board at certain places-a provision which disappears in the subsequent regulation.

As to disputes relating to navigation, they are, in accordance with the Regulations of 1815 ( $\$ 58$ ), brought before special magistrates sitting where the offioes for the collection of dues 
are established. From the decision in "first instance" appeal. may then be made either to a tribunal of appeal or to the Central Commission, which is composed of one delegate from each riparian State.

This Commission, which sits once a year, appoints a chief inspector under whose orders are placed four inspectors appointed by the Governments having jurisdiction over the parts of the river subject to their respective supervision. The inspectors have the right to apply to the local or provincial authorities whenever their intervention is necessary.

It may finally be mentioned that, following the example set by the Committee of Navigation of Vienna in 1815 ( $\$ 62$ ), the Convention of Mayence reproduces word for word in its Art. 108 the text of Art. 131 relative to neutrality in case of war, of the Convention of 1804 .

\section{The Regulation of Mannheim, Oct' 17th, 1868.}

The device, pointed out above, of whittling down, in subsequent technical provisions, a liberal principle inscribed at the head of an agreement, is still noticeable, though to a less degree, in the regulation adopted at Mannheim on October 17th, 1868, to replace that of 1831, " a part of the stipulations contained therein being no longer in harmony with the present conditions of navigation."

The Congress of Paris, 1856, which introduces the second stage of the development of our question, had taken plare and the riparian States of the Rhine had had an opportunity of hearing the opinion of certain governments concerning their interpretation of freedom of navigation. An effort was accordingly made, presumably intended to correct the bad impression and bring the regulation more into conformity with the requirement: of the times; but, of course, it did not go without the traditional restrictions and qualifications.

\section{ThF PRINCIPLe.}

Art. 1 runs as follows:

"The navigation of the Rhine and its mouths, from Basle to the sea, either in descending or in ascending, 
shall be free to the ships of all nations for the transport of merchandise and passengers, on condition of conforming to the stipulations contained in the present convention, and to the measures prescribed for the maintenance of the general security.

Except these regulations, no obstacles whatever shall be put to the free navigation.

"The Leck and the Waal are considered as forming part of the Rhine."

\section{ITS QUALIFICATIONS.}

At first sight, it appears as if we were very near the liberal idea of the Treaty of Paris, 1814: free navigation for all "so that it cannot be forbidden to anyone." But remember the words: "Except these regulations, no obstacles . . . ." They forebode the qualifications above mentioned.

In fact, there co-exist on the Rhine, so to say, a national treatment and an international treatment. The national treatment belongs to "every vessel which has the right to bear the flag of one of the riparian States, and can prove this right. by means of a document issued by the competent authority " (Art. 2).

As to the international treatment, even at the moment of signing the Convention the following reservation was entered in the closing protocol (State Papers, LIX., p. 482):

"It is understood that the right of free navigation of the Rhine and its mouths does not include (ne s'étend pas aux) the privileges which are granted only to boats belonging to the navigation of the Rhine, or to such as are assimilated to them."

The following articles of the regulation will show us how, even when the principle of free navigation to all flags is clearly proclaimed, it is still possible, by means of regulations to render it unavailable to any but the riparian subjects.

Art. 15 says:

"The right to navigate a sailing vessel or steamer on the Rhine, from Basle to the high seas, or on a section of the river belonging to several riparian States is granted 
only to those who can prove that they have actually navigated the Rhine for a given period and that they have received from the Government of the riparian State in which they are domiciled a licence permitting them the independent exercise of the profession of boatman."

'The nationality of the licensed boatman, however, is immaterial (Art. 16). But it remains to be known what the "given period" is. The following declaration of the "Protocole de Cloture" (st. Papers, .)9, p. 48\%, No. 4) informs us of it:

"It is understood that a period of apprenticeship or of service, of four years at least, will be regarded as sufficient practice of the profession of boatman; in such time the candidate must have passed at least two years on board a ship navigating the Rhine throughout its whole navigable course, or section for which he applies for a licence. Any person applying for a licence to navigate a steamer must give sufficient proof that during one out of the four years above mentioned, he has been initiated' into the practice of steam navigation . . . ."

Thus much for the captain of the vessel. As to the vessel itself, Art. 22 provides that:

"Before a vessel is allowed to undertake her first voyage on the Rhine, the owner or master must obtain a certificate stating that this vessel has the strength and sailing tackle requisite for the navigation of the section of the river for which she is destined. This certificate or boat licence is granted by the competent authority of one of the riparian States, after examination by experts . ..."this being, of course, applicable only to boats of more than 300 quintals (k) (Art. 23).

86. Waters connecting the Rhine ivith Belgium and With the high SEAS.

Art. 2, § 1, provides that:

"Vessels belonging to the navigation of the Rhine, and

(k) Equivalent to hundredweights. 
rafts on timber floats coming from the Rhine shall have the right to choose such waterway as they please when' crossing the Netherlands in order to go from the Rhine to the high seas or to Belgium $(l)$, and vice versâ.

"If, in consequence of natural accidents or of artificial works, one of the navigable waterways connecting the high seas with the Rhine viâ Dordrecht, Rotterdam, Hellevoetsluis, and Brielle, should become impracticable for navigation, the waterway indicated to Dutch vessels for navigation instead of the obstructed passage shall be open to the navigation of the other riparian States."

On all the watercourses mentioned, thus including rivers and canals connecting the Rhine with Belgium and the Scheldt. vessels belonging to the navigation of the Rhine shall enjoy "national treatment" (Art. 4).

\section{Dues, etc. ...}

On the Rhine, its international tributaries and the navigable courses mentioned in Art. 2, "no dues based solely on the fact of navigation can be levied on vessels or their cargoes . . . ." (Art. 3) $(m)$. Dredging and buoying dues are prohibited above Rotterdam and Dordrecht. Port and harbour dues are abolished (Art. 5). Export and import duties are to be the same as at the land frontiers (Art. 6), and the transit of merchandise is to be free from Basle to the sea (Art. 7).

Art. 27 provides for facilities for loading, unloading and warehousing merchandise. In order to defray the necessary expenses for these purposes a corresponding fee may be levied. But "as soon as the proceeds of these fees exceed the total of the expenses, the rate shall be decreased in proportion, and no. fee can be exacted except for the actual use of thes establishments and works..." (Art. 27) $(n)$.

(l) Cf. $\S \S 4$ and 5 of Art. 9, 1839. Much the same facilitias are granted to vessels belonging to the navigation of the Rhine as were granted to Belgian boats in 1839 ( $\$ 95$ ).

$(m)$ Reservations in closing Protocol.

(n) Cp. Prussian Law on shipping dues, 1911. A word may be said of Prussia's design to introduce shipping dues on all the rivers of the Empire, 


\section{Other Provisions.}

We are not called upon to examine the other provisions in detail. We may mention that Arts. 32 to 40 deal with the tribunals for the navigation of the Rhine, and Arts. 41 to 47 with the powers of the Central Commission, inspectors, \&c. . . . (the chief inspector being suppressed); and that the closing: Protocol contains various reservations.

There are good provisions concerning the necessity for agreement as to hydrotechnical works which may have an influence on the river (Art. 29); besides the surveillance by inspectors, it is decided that, from time to time, hydrotechnical engineers shall make tours of inspection with a view to the improvement of navigation (Art. 31); an article suppresses the use of stamped paper for the procedure concerning navigation; finally, it is understood that the free ports are: Strasburg, Kehl, Maxau. Leopoldshafen, Mannheim, Neuberg, Spire, Ludwigshafen, Mayence, Biebrich, Oberlahnstein, Coblence, Cologne, Neuss, Dusseldorf, Uerdingen, Duisburg, Ruhrort, Wesel, Emmerich, Amsterdau, Rotterdam, and Dordrecht (Closing Prot. 3).

In spite of Art. 30, which provides that:

"The riparian gorernments shall see that the navigation shall not be hampered either by mills or factories erected along the river. or by bridges or other works (ouvrages d'art) . . . ."

complaints have been made, apparently even in Germany, against certain iron bridges which fall short of the proper height and against certain pontoon-bridges (Hunningue, Brisach, \&c.), by means of which the administration of the

the Rhine included, for works, erections, buildings, \&c. . . . intended for the improvement of the traffic. The measure involved constitutional, and as far as the Rhine, for instance, is concerned, international questions. Negotiations concerning the latter have been reserved till after the passing of the bill (see Diplomatic and Consular Reports: Germany, September, 1911. Annual Series, No. 4773, pp. 101-102). But we do not know that an agreement has as yet been reached with Holland, whose consent as a riparian is, of course, necessary. Cp. Engelhardt, in Revue de Droit. linternational, XVII., pp. 109 and 609. 
empire apparently tries to hamper the development of the ports above Strasburg $(0)$.

\section{The Scheldt.}

89. From the Congress of Vienna to the Belgian RevoLUTION.

In virtue of Art. 3 (secret) of the Treaty of Paris, May 30 th, 1814, two articles (Arts. 1 and 7 ) concerning the free navigation of the Scheldt were inserted in Annex 16 to the Final tet of Vienna $(1815)(p)$ : and the Scheldt remained open until $1830(q)$. But when the Belgian Revolution broke out, the Dutch hastened to revive the provisions of the Treaty of Münster (1648, Art. 14) ( $\$ 5$ and $\S 31$ ), and closed the river. On the representations of the Great Powers, this measure was revoked, and the Scheldt was re-opened on January 20th, 1831.

\section{The Conferences of London (1830-1839).}

At the Conference of London which opened on November 4th, 1830 , it was deemed necessary to settle the régime of the river and embody the settlement in the treaty of peace. The attitude of the Dutch rendered special stipulations indispensable besides the mere application of Arts. 108 to 117 of the Final Act of Vienna.

The Belgian plenipotentiaries insisted on subjecting the pilotage, buoying, police and repairs of the river from Antwerp to the sea to the joint supervision of both States (see and compare Belgian and Dutch projects : Annex $\mathrm{C}^{1}$ and Annex $\mathrm{D}^{1}$ of Protocol 46, October 1st, 1831, in Protocols of Conferences in London relative to the affairs of Belgium).

(o) Le Régime juridique des cours d'eau internationaux de l'Europe entrale, par J. Valotton. Rev. de D. intern., 2nd série, XV., p. 279. 31. Valotton, be it said by the way, develops the point of view of Switzerland conceruing the neutrality of that country and the extension of the liberty of navigation above Basle (to the Swiss part of the Rhine).

(p) Cp. $\$ 65$.

$(q)$ Sixty-three kilometres of its coursebeing navigable in French territory, it remained an international river in spite of the union of the Belgian with the Dutah provinces (French ports: Condé and Valenciennes). 


\section{Holland's objections.}

The Dutch reply to this claim is in Annex A. and B. of Prot. 53, January 4th, 1832:

"There is no example, as far as we know, in the history of treaties, that an independent State has ever agreed to share with another Government the supervision of the pilotage and buoying (balisage) of one of its own rivers; that it has consented to fix the pilotage dues in agreement with a foreign State . . . .; that it has subscribed to a deed allowing it to navigate its own rivers . . . . ; that, in respect to the navigation of its internal waterways, it has subjected its own commerce to the same dues as that of foreigners, and granted to another State the right of fishing and trading in fish on the whole extent of ono of its rivers-a stipulation which has its parallel only on the coasts of certain colonies.

"The Government of the Netherlands cannot subscribe to these clauses which are derogatory to the rights of sovereignty of any independent State. . . ."

But, added the memorandum, it would be ready to give its adhesion to a convention of the same kind as that which was signed at Mayence, on March 31st, 1831, concerning the Rhine (\$ 82).

92. The answer of the Powers-Holland's rights OF SOVEREIGNTY.

Would it not have boen inconsistent, in an endeavour to ensure free navigation, to leave the exercise of the rights on which this freedom rests, entirely in the hands of a single riparian State? The Conference stood by the Belgian claims. To the Dutch plenipotentiaries who declared that they could not possibly reconcile the principle of common supervision with the "first principles of the code of nations," the Conference pointed out "que le droit des gens général est subordonné au droit des gens conventionnel, et que, quand une matière est. régie par des conventions, e'est uniquement d'après ces con- 
ventions qu'elle doit être jugée" $(r)$. Indeed, the Conference observed, the navigation of international rivers has been the object of special agreements between States; it is not, therefore, to abstract principles, but to the spirit of the treaties which at this moment form the Political Code of Europe that recourse must be had. These treaties have curtailed privileges which the general law of nations used to acknowledge. By them, the various Governments have renounced the right of closing their rivers to the commerce of other nations; they have renounced the right of staple, of breaking bulk (romprecharge); in short, they have assented to everything calculated to make effectual the principle of free navigation. Therefore, in determining the clauses necessary effectually to ensure, freedom of navigation on the Scheldt, the Conference doet not infringe the principles of the code of nations, but acts in conformity with the public law of Europe.

"So entirely, they said, has the sovereignty of the King of Holland been respected, that, in drafting the transitory provisions, the Conference have subjected the definitive state of things, which is to be the outcome of Art. 9, to subsequent negotiations between the two parties."

The tenor of the article, besides, implies only reciprocal measures, all the more necessary because the Conference has heard Holland speak of the right of closing the Scheldt, and has been apprised that, for want of proper attention to the buoys and beacons, the navigation of the river is beginning to be difficult $(s)$ (Annex D of Prot. 53, January 4th, 1832).

(r) Sovereignty eannot be a tyrant overruling covenants and good faith, and heaping up obstacles in the way of Justice and Progress. Granting that no existing right of a nation can be suppressed without her consent, when a question has been subjected to negotiation, whatever concessions a nation has made, she has made them in the exercise of her sovereignty, and no alleged rights of sovereignty can be set up afterwards to mitigats or annul the decisions agreed upon.

(s) Cp. what happened on the Danube after the Convention of St. Petersburg, 1840 ( $(98)$. If the lower course of an international river remains under the exclusive control of one State, a little voluntary negligence on 
The same note, in reply to the offer of Holland to "assimilate" in her own waters Belgian ressels to Dutch vessels-a deviee which had been resorted to on the Rhine (\$ 82)-observes that such an offer is not acceptable. Indeed, if on the Rhine it is a suficient guarantee for the upper riparians to have their own ships placed on the same footing as Dutch ships in Dutch waters on account of the great importance of that river for the navigation and commerce of some of the most important Dutch towns, one meets with a condition of things far different in respect of the Scheldt. The interest of Holland in the navigation of this river bearing no comparison with that of Belgium which is quite vital, it is necessary to give Belgium and the port of Antwerp "une garantie de plus."

\section{ARt. 9.}

After lengthy negotiations, and the right of levying tolls being granted to the Dutch, Art. 9 of the Treaty of London, April 19th, 1839, stipulated, in addition to the application of Arts. 108 to 117 of the Final Act of Vienna (1815), for the supervision in common of pilotage and buoying, as well as the keeping of the channel in good repair below Antwerp. It was added. that such supervision should be exercised by delegates appointed by both nations; that the dues of pilotage should be fixed in common, and should be moderate and the same for the vessels of all nations (a stipulation of great importance as implying the right for the ships of all nations to navigate on the Scheldt). As to fishing, the subjects of both nations should enjoy equal rights on the whole river. Finally, in case the channels contemplated in the article should become impracticable, the Dutch Government engaged to open other channels, equally good and safe, to narigation.

This is the text of the article $(t)$ :

"Art. 9.-\$ 1. The provisions of Arts. 108 to 117, inclusive, of the General Act of the Congress of Vienna,

its part may suffice to deprive all the co-riparians of the full benefit of their rights.

(t) State Pajers, XXVII., pp. 994-996. 
relative to the free navigation of navigable rivers, shall. bo applied to the navigable rivers which separate the Belgian and Dutch territories, or which traverse them both.

"§ 2. So far as regards especially the navigation of the Scheldt, and its mouths, it is agreed that the pilotage and the buoying of its channel, as well as the keeping: in good order of the channels of the Scheldt below Antwerp, shall be subject to a joint supervision; and that this joint superintendence shall be excreised by Commissioners to be appointed for this purpose by the two parties. Moderate pilotage dues shall be fixed by common agreement, and thase dues shall be the same for the vessels of all nations.

"In the meantime, and until these dues shall have been fixed, no higher pilotage dues shall be levied than those which have been established by the tariff of 1829 , for the mouths of the Meuse from the high seas to Helvoet, and from Helvoet to Rotterdam, in proportion to the distances. Every vessel proceeding from the high seas to Belgium or from Belgium to the high scas shall be free to take what pilot she pleases; and accordingly the two countries shall be free to establish along the whole course of the Scheldt and at its mouths, such pilotage establishments as shall be deemed necessary for furnishing pilots. Everything relating to these establishments shall be determined by the regulations to be concluded in conformity with $\$ 6$ below. These establishments shall be placed under the joint superintendence mentioned in the beginning of the present paragraph. The two Governments engage to preserve the navigable channels of the Scheldt, and of its mouths, and to place and maintain therein the necessary beacons and buoys, each for its own part of the river.

" $§ 3$. There shall be levied by the Government of the Netherlands, on the navigation of the Scheldt and of its mouths, a single duty of 1 florin 50 cents. per ton, that in to say, 1 florin 12 cents. on vessels which, coming from the high seas, shall ascend the Western Scheldt in order to procoed to Belgium by the Scheldt or by the Canal of 
Terneuzen; and of 38 cents. per ton on vessels which, coming from Belgium by the Scheldt or by the Canal of Terneuzen, shall descend the Western Scheldt in order to proceed to the high seas. And in order that the said vessels may not be subjected to any visit, nor to any delay or hindrance whatever within the Dutch waters (dans los rades hollandaises) either in ascending the Scheldt from the high seas, or in descending the Scheldt in order to reach the high seas, it is agreed that the dues above mentioned shall be collected by Dutch agents at Intwerp and at Terneuzen. Vessels coming from the high seas in order to proceed to Antwerp by the Western Scheldt, and coming from places suspected in regard to health, shall likewise be at liberty to continue their course without hindrance or delay, accompanied by one health officer, and thus to proceed to the place of their destination. Vessels proceeding from Antwerp to Terneuzen, and vice versâ, or carrying on in the river itself coasting trade or fishery (in such manner as the exereise of the latter shall be regulated in pursuance of $\$ 6$ hereinafter) shall not be subjected to any duty.

" $\$$. The branch of the Scheldt ealled tha Eastern scheldt, not being in its present state available for the navigation from the high seas to Antwerp and Terneuzen, and vice vers $\hat{a}$, but being used for the navigation between Antwerp and the Rhine, this eastern branch shall not be burdened, in any part of its course, with higher dues or tolls (péages) than those which are levied, according to the tariffs of Mayence of the 31st of March, 1831, upon the navigation from Grorcum to the high seas, in proportion to the distance.

" $§ 5$. It is also agreed that the navigation of the intermediate channels between the Scheldt and the Rhine, in order to proceed from Antwerp to the Rhine, and vice versâ, shall continue reciprocally free, and that it shall be subject only to moderate tolls, which shall be the same for the commerce of the two countries.

" $\$$. Commissioners on both sides shall meet at 
Antwerp within one month, as well to determine the definitive and permanent amount of these tolls, as to agree upon a general regulation for the execution of the provisions of the present article, and to include therein a provision for the exercise of the right of fishing and of trading in fish, throughout the whole extent of the Scheldt, on a footing of perfect reciprocity and equality in favour of the subjects of the two countries.

" $§ 7$. In the meantime, and until the said regulations shall have been prepared, the navigation of the Meuse and of its branches shall remain free to the commerce of the two countries, which shall provisionally adopt, in this respect, the tariffs of the Convention signed at Mayence on the 31st March, 1831, for the free navigation of the Rhine, as well as the other provisions of that Convention, so far as they may be applicable to the said river.

" $§ 8$. If natural events or artificial works should hereafter render impracticable the waterways mentioned in the present article, the Government of the Netherlands shall assign to Belgian navigation other waterways equally safe, and equally good and commodious, instead of the said waterways become impracticable."

\section{Abolition of the tolls in 1863.}

These provisions are still in force, except that the tolls which Holland had been authorised to levy were bought up by Belgium in 1863, with the help of contributions from twenty-one nations and free towns (State Papers, LIII., pp. 8-19).

Several of these provisions are somewhat remote from our subject. But, as Art. 9 is truly the "Charter of the Scheldt," it has been reproduced in full.

The question which concerns us most, viz., that of the communication of the port of Antwerp with the sea, is dealt with in $\S \S 1,2,3$, and 8 , the practical provisions of which (still valid after 1863) may, for clearness' sake, be tabulated as follows:

(a) Application of Arts. 108 to 117 of the Final Act of the Congress of Vienna. 
(b) The two governments engage to preserve the navigability of the channels of the Scheldt and its mouths, and to place and maintain the necessary beacons and buoys, each in its part of the river; the pilotage, the buoying and the conservation of the channels are subject to the joint superintendence of Commissioners appointed for this purpose by the two countries.

(c) Holland is not to hamper the passage in its waters of vessels bound to Belgium, either by refusing a pilot, or by imposing sanitary regulations, or formalities.

(d) Vessels are free to choose between a Belgian and a Dutch pilot; both States are free to establish, along the river and at its mouth the necessary pilot stations, and they fix by common agreament the tariff of pilotage dues, the same for the vessels of all nations.

(e) The only sanitary measure which Holland is permitted to take is the placing of a health officer on board suspected vessels, until they arrive in Belgian waters.

(f) In case the present channels should become impracticable, Holland would have to assign to Belgian navigation other channels equally safe, good and commodious.

Such were the principal general provisions, the execution of which the two riparian countries were to regulate in detail between themselves in subsequent conventions.

\section{The Treaty of Limits-Waterways connecting Belgium witir the Rhine.}

A few months after the conclusion of the treaty, a provisional agreement was made (October, 1839) concerning the Scheldt (Stats: Papers, XXVIII., pp. 1116-1129), but many details, left without solution by the Treaty of April, 1839, remained to br settled by special conventions, one of which was the "Treaty of Limits" signed at The Hague on November 5th, 1842 (State Papers, XXXI., pp. 815 sq.-Chap. II., p. 818).

It regulates several questions concerning the navigation of the Scheldt, the Canal of Terneuzen, and the waterways connecting the Western Scheldt and the Meuse with the Rhine.

We analyse its principal provisions: 
(a) Concerning the Scheldt: vessels going from the high seas to Belgium and vice versâ, are exempt from eustoms formalities in Dutch waters; the Dutch Government engages to establish lights (fanaux) and maintain beacon-fires (feux: for which Belgium will pay a compensation; Belgium may establish a pilot-station at Flushing, and station pilots at Terneuzen. Holland may establish a pilot-station in Antwerp; these establishments are legally recognised by both Governments which engage to help and protect them.

(b) Concerning the Canal of Terneuzen: Belgian and Dutch vessels using the canal are exempt from dues on navigation or tolls for the passage of bridges and locks (la manœuvre des ponts et des écluses); they are also exempt from the customs formalities when they enter into, go out of, or navigate the canal, except, of course, "the placing of seals on hatchways and other means of egress," or the placing of a watch on board; vessels with cargoes in transit from Ghent to the Rhine and vice versâ, along the canal, shall not be subject, with respect to customs, on Dutch or Belgian territory, to other formalities than those stipulated for with regard to the waterways connecting the Western Scheldt with the Rhine.

(c) Concerning the waterways connecting the Western Scheldt, with the Rhine (intermediate waters), including the Sloe, the Eastern Scheldt and the Meuse: reciprocal freedom of navigation between Belgium and the Rhine and yice versâ $(u)$; abolition of compulsory transhipment or breaking bulk when passing from the Scheldt into the Rhine, and vice. versâ, through the Netherlands; granting to Belgian vessels navigating the Rhine in Holland all the advantages stipulated for by the Convention of Mayence, 1831, in favour of the subjects of the riparian States; goods in transit from Belgium to the Rhine and vice versâ, to be subject to a fixed duty, in addition to the dues for pilotage, lights (fana,ux) and buoys (balisage); the said goods to be admitted into the warehouses of Dordrecht, Rotterdam and Amsterdam.

(u) By the Convention of Mannheim, 1868, the Netherlands have extended this favour to all the vessels belonging to the "navigation of the Rhine" (§ 86). 
(d) Concerning the Meuse: tariff of dues in conformity with the Act of Vienna, from the French frontier to Gorcum; vessels going up or down may navigate the Waal bretween Rossum and Gorcum instead of the Lower Meuse; goods in transit are admitted into the Belgian warehouse of Liège, and into the Dutch warehouses of Dordrecht, Rotterdam and Amsterdam.

\section{Regulations.}

It was not until an agreement was reached on all these points that the regulations on navigation could definitely be made. They were seven in number, signed in Antwerp on May 20th, 1843. One deals with dues, another with pilotage and common supervision; a third with lights and beacon-fires (feux et fanaux); a fourth with fishing; the fifth regulates the navigation of the waterways connecting the Scheldt with the Rhine; the sixth deals with the Meuse, and the seventh with the Canal of Terneuzen $(x)$.

An analysis of these regulations would be superfluous. They follow tolerably closely Art. 9 and the general principles which we have outlined in connection with the Treaty of Limits ( $\$ 95)$. However, a few words may be neckssary about the organisation of the supervision in common such as is defined in $\S 2$ of Art. 9 ( $\$ 93)$. It is entrusted to commissaries who must meet at least once every three months, alternately in Antwerp and Flushing, the two ports where the pilot-stations (pilotages) are. These meetings have for their object the inspection of the buoys, beacons, and the navigable channels as well as of the service of pilotage. As the two Governments have engaged to preserve the navigability of the channels of the Scheldt and its moutlis, and to place and maintain the necessary buoys and beacons, each on its section of the river, the Commissaries, whenever they think proper to inspect the river, whether jointly or separately, are to observe with cara all the alterations which may have taken place in the bed and

(x) These regulations are reproduced in "Nouveau Recueil de Traités," by F. Murhard (continuation of Martens), V. (1813), p. 294 foll. 
the ordinary channels, examining whether, as a consequence, the buoys and beacons are still in the proper place and in sufficient number. They are also to make sure that buoys and beacons are not out of place from other causes, and whether they could not be better and more securely placed.

But it is important to notice that they are not allowed to order directly the replacing of a buoy or beacon, except when this is urgently needed. With the exception of a case recognised as urgent by the Commissaries of the two States, the Governments themselves are alone entitled to act, and examples are known of requests made at the instance of the Commissaries of one State, notably with regard to the dredging of chann ls: getting blocked up by sand, being simply ignored by the administration of the other State.

This is mostly due to the possibility of there being divergent opinions as to what is "necessary," as the Treaty uses this term without any indication as to its interpretation. With very unequal interests in the maintenance and improvement of the river, the two Governments are apt to have different standards of what is "necessary." In any case, muc's the greater part of the financial burden for the maintenance of the river falls. upon Belgium.

Whenever the Commissaries of the two Governments nreet, minutes of their deliberations are to bз drawn up in duplicate. Maps of the river, in duplicate, shall constantly ba kipt up to date. In case of disagreement, the divergent opinions must be mentioned in the procès-verbal, and the Commissarios nust refer the question to thoir respective Governments.

If, during a separate inspection, one Commissary notices anything noteworthy, he has to inform his colleazue of it at once.

With regard to pilotage, the common supervision dors not extend beyond the active sarvice of pilotage.

97. War buoying on the Scheldt $(y)$.

Not only the supervision in common, but the agroment

(y) On the hypothesis of a war, Holland remaining neutral, sce Ay: II.. pp. 155-6.

K. 
of the two Governments is indispensable for any alteration of the lighting and buoying. Generally, when the Commissaries are agreed, a convention is signed between the sovereigns of the two countries. Several of these conventions contain interesting provisions. For instance, in the Convention of October 26th, 1866, concerning the establishment of new lights, one reads:

"The Dutch Government shall see that the constructions, lighting apparatus and whatever depends on them, be kept in good repair. It shall neither take them away, nor displace them, nor divert them from the use for which they are intended, without the consent of Belgium."

And the Convention of February 9th, 1881, concerning buoying, provides that:

"The Dutch Government shall see that the beacons, high and low water marks (échelles de marée) and buoys are preserved in good working order. It shall neither take them away nor divert them from their intended use, without the consent of Belgium."

Such was the rule, unqualified and well established, when in 1891, à propos of another Convention, Holland raised an objection. She admitted the necessity for agreement concerning all alterations or improvements in time of peace; but " in time of war, or in the eventuality of war" she claimed full liberty of action. Belgium yielded (June 8th, 1892). Holland thus henceforth became entitled to take away the lights, beacons and high and low water marks, i.e., practically to put a stop to frec navigation in time of war, or even in contemplation of a threatening war, without Belgium's having anything to $\operatorname{say}(z)$.

This regrettable concession made by Belgium in 1892, was confirmed by a statute of September 23rd, 1905, and was confirmed with an addition by a statute of May 20th, 1908, approving a Convention of October 8th, 1907, for the improvement of the lighting and buoying of the Scheldt.

(z) This takes us some way from the provisions adopted in 1804 and 1815 in order to ensure, as far as possible, in time of war, the continuation of navigation on international rivers. 
On August 3rd, 1914, on the eve of the invasion of Belgium by the German army, the Dutch Minister for Foreign Affairs notified to the Belgian Minister at The Hague "that the Netherlands Government would, perhaps, be obliged, owing to the gravity of the present situation, to institute war buoying on the Scheldt." The steps taken were tantamount to interrupting narigation at night and forcing vessels going to, or coming from, Belgium, to take Dutch pilots exclusively (Belgian Grey Book, No. 29 and No. 50, cp. § 2, Art. 9, Treaty, 1839)

In fact the common supervision has been altogether rendered impossible

\section{The Danube.}

98. The Danube before 1856.

In spite of the extraordinary importance of the Danube as an international river connecting Europe with Asia, the Congress of Vienna, 1815, did not concern itself with it, because its middle and lower course were under the dominion of Turkey which had not yet been admitted to the European State system.

The annexation of Bessarabia by Russia in 1812, and the extensior of her power to the mouths of the Danube in 1829, together with the rekindling of the Austrian interest in the navigation of the Danube by Count Czecheny and the introduction of steam navigation on the upper river, owing to the initiative of two Englishmen, largely determined the subsequent history.

With a larger river fleet, Austria, cherishing the hope of restoring her economic influence on the lower river as far as the sea, in 1840 signed the Convention of St. Petersburgthe first attempt, the preamble declares, to apply to the Danube the principles of Vienna. Russia, however, which had agreed by Art. 5 of the same convention to keep the branch of Sulina fit for navigation, preferred to her own covenanted obligation the selfish object of benefiting the port of Odessa by keeping down the navigation of the Danube. Austria saw with dismay the Sulina branch becoming gradually blocked up with sand and vexatious tolls and quarantines being imposed, and, in her 
endeavour to obtain access to the sea, was elaborating plans for a canal connecting Cernavoda with Constantza and for a system of carriage by land, when the Crimean war opened up new vistas.

Russia being defeated was forced to come to terms with the European Powers.

\section{The Treaty of Paris.}

\section{A. Preliminaries.}

99. Thiz bases of negotiation.

In March and April, 1855, the plenipotentiaries of Austria, France, Great Britain and Turkey were assembled in Conference in Vienna, under the presidency of Count BuolSchauenstein, the plenipotentiary of Austria. "A common object brings us together in this place," declared the president at the first sitting on March 15th, "that of arriving at a sincere agreement to restore to Europe that peace of which she stands so much in need."

Then, after having declared that "the indispensable conditions on which the work of peace must rest" have received the asser.t of the Emperor of Austria and of his allies, and have been communicated to the delegate of Russia who has agreed to take them as bases of the negotiations, he summed them up in four points, of which the second was:

"The freedom of the navigation of the Danube shall bo completely secured by effectual means, and placed under the control of a permanent syndical authority."

The French plenipotentiary, Baron de Bourqueney, declared that "it is in the name of European interests that his Government has undertaken to make those principles prevail; and his Government will not cease to pursue the career of sacrifice until they shall have been placed, with all their consequences, in the public law of Europe."

In a memorandum of December 28th, 1854, to Prince Gortchakoff, the plenipotentiaries of the Powers, examining 
the bases of negotiation, had already explained as follows their intentions concerning the Danube:

"To give to the freedom of the navigation of the Danube all the development of which it is susceptible, it would be desirable that the course of the Lower Danube, beginning from the point where it becomes common to the two riparian States, should be withdrawn from the territorial jurisdiction existing in virtue of the third article of the Treaty of Adrianople. In any case the free navigation of the Danube could not be secured, if it were not placed under the control of a syndical authority, invested with powers necessary to destroy the obstructions existing at the mouths of the river, or which may hereafter be formed there."

\section{The "second basis."}

At the Conference of March 21st, Baron Prokesch (a) reads a memorandum in which he sets forth his ideas on the practical application of the principle of free navigation to the Danube. This memorandum is taken as the basis of the discussion which, at the Conference of March 23rd (Prot. 5) results in fixing as follows the terms of the second basis of negotiation:

"I. The Act of the Congress of Vienna to which the Sublime Porte was not a party, having established in its articles 108 to 116 the principles intended to regulate the navigation of rivers which traverse several States, the Contracting Powers mutually agree to stipulate that, for the future, these principles shall be equally applied to the lower course of the Danube, from the point where the river becomes common to Austria and the Ottoman Empire to the sea. This arrangement shall henceforth form part of the public law of Europe, and shall be guaranteed by all the Contracting Powers.

"II. The application to be made of these principles must be entirely, with the riew of facilitating commeres

(a) Representative of Austria. 
and navigation, so that the navigation of this portion of the Danube shall not be subjected to any obstacle or impost which is not expressly provided for by the following stipulations, and that from henceforth also the privileges and immunities founded on the ancient treaties and the ancient capitulations with the States bordering on the part of the river in question, which are not opposed to the principle of the freedom of navigation, shall be maintained intact. Consequently, there shall not be levied throughout the whole course above mentioned of the Danube any toll founded exclusively on the fact of the navigation of the river, nor any duty on the goods on board of ships, nor shall any obstacle of any kind whatever be offered to free navigation. The measures of precaution which it may be desirable to adopt in regard to customs and quarantine, shall be limited to what is strictly necessary, and shall be placed in harmony with the requirements of freedom of navigation.

"III. In order to remove the most important obstacle to the navigation of the Lower Danube, the necessary works shall be undertaken and finished with the least possible delay, as well to free the mouth of the Danube from the sandbanks which obstruct it, as to remove other physical impediments which obstruct the navigation of the river in other places higher up its course; so that the passage as far as Galatz and Ibrailla of merchant vessels of the largest tonnage shall be freed from the dangers, hindrances, and losses with which it has hitherto had to contend. In order to defray the expenses of these works, and of the establishments intended to secure and facilitate the navigation, certain dues fixed at a suitable rate may be levied on vessels navigating the Lower Danube, on the express condition that in this respect, as well as in every other, the flags of all nations shall be treated on a footing of perfect equality.

"IV. In order to carry out the stipulations contained in the preceding article, the Contracting Powers, in consideration of the European interest which is attached to 
the complete opening of the Danube in its navigable branches, or in those which are to be made navigable as far as the sea, will assume, by common consent, within the limits traced by the Final Act of the Congress of Vienna, the direction and the guarantee of their execution, as they will also undertake the supreme control over the maintenance of the principle of the opening of the Danube. For this purpose they will determine, with the aid of a European Commission, composed of delegates from each of them, the extent of the works to be executed, and that of the means to be employed to do away with the physical and other obstacles which impede, up to the present time, the free navigation of the part of the river between Galatz and the sea. This European Commission, which shall be dissolved only by common consent, will draw up the bases of a regulation for navigation and for river and maritime police to be applied to the Danube in its abovementioned course, and wiil draw up instructions to serve as a guide and a rule for a River-bordering Executive Commission, composed of delegates of the three riverbordering States, namely, Austria, Russia and Turkey.

"V. The River-bordering Commission called upon to act in the name of Europe as an executive authority shall be permanent. It shall be furnished with the necessary powers for fulfilling its task in the most efficacious and most complete manner.

"VI. Russia will consent never to re-establish on the Sulina branch the line of quarantine which she formerly established there. She will take care that none of her military establishments situated between the confluence of the Pruth with the Danube, and the point where the branch of St. George is separated from that of Sulina, shall impede the vessels navigating the river. As to the part of the river between the point of the above-mentioned branching off, and the mouths of St. George and Sulina, there shall bo no fortification. Being desirous to insure on her part, with an anxiety equal to that of the other Contracting Powers, the free navigation of the Danube, Russia engages to 
forward by all means in her power the operations of the permanent Commission."

\section{Some aspects of THE Discussions.}

It is interesting to note some of the principal points of the discussions (Prot. 4 and 5).

\section{2.-A. Twofold aspect of the PRoBlem.}

Prince Gortchakoff observed that the problem presents a political aspect and a practical commercial aspect. From the political point of view, Russia adheres to the principle of freedon of navigation for all merchant flags. From the commercial and practical point of view, she is ready to help to remove the natural obstacles which hinder the navigation of the Danube and its mouths.

\section{3.-B. Russia objects to a "European syndicate."}

Wo read in Prot. 4 of March 21st, 1855: "In connection with the fourth article, which says that the delegates of the Contracting Powers, acting as an European Syndicate, shall establish the basis of fluvial and maritime legislation for the navigation of the Lower Danube, the Russian plenipotentiarics objected to the use of the term 'Syndicate,' because it did not convey a clear and precise idea, and because, moreover, it was quite unusual in international relations.

"Prince Gortchakoff said that the second of the four principles established had for its object to secure the complete freedom of the navigation of the Danube; that the regulating commission, which had been styled 'Syndicate,' would bear a scientific and technical character; that the question related to commerce, and that it was of importance not to mix up with it political considerations.

"Baron Bourqueney observed that it was impossible to divest of all political character a question which had been raised to the importance of an European guarantee; that, however sincere might have been the intentions of the Russian Government on the subject of the free navigation of the Danube, the entirely different results which had notoriously ensued, were such as 
to justify even an excess of precautions (un surcroît de précautions), and that the Syndicate could not be anything else than the representative of the interests of all.

"Prince Gortchakoff declared that if the word 'Syndicate implied the exercise of any right of sovereignty, he must object to it."

At the next sitting, the discussion on the value of the word "Syndicate" was resumed (Prot. 5).

"Prince Gortchakoff having declared that the objections which he had raised to this term did not in any way affect the institution itself, and had no other object than to find a word better adapted to the idea which it was intended to express, it was agreed to substitute for the term 'Syndicate' that of 'European Commission'" (b).

\section{4.-C. The "Stationaries" at the mouths of the Danube.}

The memorandum of Baron Prokesch contained the following clause: "Each of the Contracting Powers shall have the right to station one or two vessels of war at the mouths of the river.'

(b) In this connection, it is interesting to note the following extract from the "Instructions to Lord John Russell on proceeding to Vienna":

"Again, as regards the second basis, the abrogation of the rights of Russia to interfere with the freedom of the navigation of the Danube might. be most effectually secured by the retrocession to Turkey in the first instance of the territory at the mouth of the river which she renounced at the Treaty of Adrianople, subject to the condition that the retroceded territory should be placed by the Porte under the safeguard of the Great Powers of Europe, acting in concert with the Porte for the preservation of all the navigable channels of the river from the exclusive domination of any one Power, and for the removal of the obstructions which now impede, and have long threatened to render the channel of the Danube altogether unserviceable for the purposes of commerce. A mixed Commission, in which England and France should be represented, should be appointed to regulate all matters belonging to the navigation. But if Russia enters upon the discussion with a sincere desire to meet the reasonable wishes of the Powers most interested in the navigation of the Danube, there may be ground to expect that those questions will receive a favourable solution by the establishment of a syndicate authority, invested with the necessary powers for the destruction of the obstacles now existing at the mouths of the river, or which might hereafter grow up there. ..." 
It was not reproduced in the definitive wording. The question was reserved, as the Treaty of July 13th, 1841, concerning the closing of the Straits, still subsisted; but the principle did not at the time give rise to any objection.

105.-D. The executive Commission to consist of Riparians ONLY-AUSTRIa WISHES TO CONFINE IT to THE LOWER DANube.

Baron Prokesch assigned to a Commission consisting of the delegates of the riparian States the executive power of the European syndicate. Lord John Russell expressed the desire of his Grovernment to be also represented on the executive Commission on account of England's important interests on the Danube. But the Austrian plenipotentiary replied that " according to the Act of the Congress [of Vienna], Commissions of navigation were to consist only of the delegates of the riparian States, and that Austria, as far as related to that portion of the Danube which crosses her territory, held to the strict application of that stipulation.

"Prince Gortchakoff, in adhering to the principle established by Count Buol, requested that it should be applied equally to Russia. With reference to this point he asked whether the German States, whose territory is crossed by the Danube, and especially Bavaria, should not be represented in the Commission. Baron Prokesch replied, that there existed special stipulations between Austria and Bavaria respecting the navigation of the upper part of that river, and that the only question now was, to regulate the navigation of the Lower Danube" $(b)$.

\section{6.--E. Neutralization of the Delta.}

In order to facilitate the work of the Commissions, Baron Prokesch's memorandum proposed to neutralize the Delta of the Danube. This proposition was rejected in the text adopted $(c)$.

(b) At the Congress of Paris, Austria maintained these views ( $\S 110 s q q$. .). She was, however, forced to yield to some extent, while making reservations ( $\$ 115$ ).

(c) On neutralization, see $\$ \S 254-264$, discussions in 1885 . 
The discussions which had taken place in Vienna were suspended owing to the impossibility of reaching an agreement with regard to the third basis concerning the position of Russia on the Black Sea. They were resumed the next year.

\section{B. The Congress.}

The Conferences were held in Paris under the presidency of Count Walewski.

107. The text of the preliminaries.

At the first Conference, February 25th, 1856, the President observed that no text had been definitively fixed upon for the preliminaries of peace. In consequence, he proposed to accept as such the project of preliminaries signed in Vienna on February 1st, 1856. This motion was accepted.

We need reproduce only the second proposition concerning the Danube. It ran:

"The freedom of the Danube and of its mouths shall be effectually secured by European institutions, in which the Contracting Powers shall be equally represented, without prejudice to the special position of the riparian Powers, which shall be settled upon the principles established by the Act of the Congress of Vienna on the subject of river navigation.

"Each of the Contracting Powers shall have the right of stationing one or two light ressels of war at the mouths of the river for the purpose of ensuring the execution of the regulations relative to the liberty of the Danube."

108. Thie "Stationaries" and the neutralization of the Black Sea.

At the second Conference, February 28th, took place a first examination of the preliminaries. With respect to the stationaries at the mouths of the Danube, Count Orloff observed that the stationing of war vessels bearing the flags of Powers not bordering on the Black Sea, would constitute a violation of the principle of its neutralization: but Count Walewski 
replied that an exception agreed upon by the Contracting Parties could not have the character of an infringement. Count Buol remarked that these ships would in any case have the power of moving about freely in the Black Sea; the nature and requirements of their service admitted of no doubt on that point. Baron de Brunnow (Russia) observed that the object of their mission was, however, clearly defined.

\section{The draft proposed by Count Walewski.}

After having discussed the régime of the Black Sea, the plenipotentiaries, at the fifth sitting, March 6th, 1856, passed to the question of the Danube. The document agreed upon in Vienna on March 23rd, 1854 (reproduced $§ 100$ ), was read, and the President presented the following draft:

"I. The Act of the Congress of Vienna having established the principles intended to regulate the navigation of rivers which traverse several States, the Contracting Powers stipulate among themselves that these principles shall in future be equally applied to the Danube and its mouths; they declare that this arrangement henceforth forms part of the public law of Europe, and take it under their guarantee.

"The navigation of the Danube cannot be subjected to any impediment or charge not expressly provided for by the stipulations which follow: in consequence, there shall not be levied any toll founded solely upon the fact of the navigation of the river, nor any duty upon the goods which may be on board of vessels, and no obstacle whatever shall be opposed to the free navigation.

"II. The Sublime Porte engages to cause to be executed, in conjunction with the Local Governments in the Principalities, the works which are at present, or which may become, necessary, as well to clear the mouth of the Danube from the sands which obstruct it, as to put the river in the best possible state for navigation at other points in the upper part of its course, especially between the ports of Galatz and Braïla.

"In order to cover the expenses of such works, as well 
as of the establishments intended to secure and to facilitate the navigation, fixed dues at a suitable rate may be levied on ships navigating the Lower Danube, on the express condition that, in this respect as in every other, the flags of all nations shall be treated on a footing of parfect equality.

"III. With a view to carrying out the arrangements of the preceding article, a Commission, which can only be dissolved by common consent, and composed of . . . . shall be charged with the duty of determining the extent of the works to be executed, and of preparing the bases of $a_{4}$ regulation for navigation, and for river and maritime police; it shall also draw up instructions intended for the guidance of an executive Commission.

"IV. In conformity with the stipulations of the Treaties of Vienna, this Commission will be composed of . . . . in their quality of river-bordering States; it will be permanent. In case of disagreement relative to thr interpretation of the established regulations, reference shall be had to the Contracting Powers.

"V. In order to ensure the execution of the regulations which shall have been drawn up by common consent in accordance with the principles above set forth, each of the Contracting Powers shall have the right of stationing (one or two) light vessels at the mouths of the Danube."

\section{Austria insists on DeAling ONLY With the Navigation} of the Lower Danube.

On the proposition by Count Walewski to invite Bavaria, as a riparian Power, to send representatives to the exceutive Commission, Count Buol remarked "that the regulation of which this Commission will have to superintend the execution, ean affect only the interests of the navigation of the Lower Danube; that the navigation of the Upper Danube has not given rise to any dispute among the interested parties, and that there can be no reason for giving to the authority of the Commission an extension for which there is no justification.

"The first plenipotentiary of France replied: that the 
Congress had to deal with a general question affecting the navigation of the river; that it had been thus laid down in the document which forms the basis of the negotiation; and that, from the moment it was agreed that the Commission styled executive was to be composed of the riparian States, it became impossible to exclude Bavaria from it. He added that, moreover, the text of the proposed articles admitted of no ambiguity and sufficiently indicated the nature of the attributes of this Commission."

\section{Examination of Count Walewsit's dRaft-Aestri.} RENEWS HER OBJECTIONS.

When, on March 12th (Prot. 8) the Congress resumed the discussion of the draft presented by Count Walewski at the fifth Conference, Count Buol again argued in farour of confining the attention of the Congress to the Lower Danube.

"The principles established by the Congress of Vienna, he. said, lay down, as the principal provision, that the riparian Powers shall be exclusively entitled to make regulations of river police, and to superintend the execution of such regulations. The European Commission, mentioned in Prot. 5, will comprise, besides the delegates of the riparian Powers of the Danube, delegates from non-riparian Powers; the permanent Commission, which is to be substituted for the European Commission, will be charged with executing the resolutions adopted by the latter; in consequence, and in order to abide by the spirit as well as the terms of the Act of the Congress of Vienna, both Commissions should confine their labours to the Lower Danube and its mouths."

\section{Argunents for the application of the prisciple to} THE WHOLE RIVER.

Count Walewski refuted this argument by referring to the bases of negotiation accepted by all the Contracting Powers (see $\S 107$ ); and the Earl of Clarendon added that, if the principles under discussion were not applied to the whole river, "Austria, remaining alone in possession of the Upper Danube and sharing in the navigation of the lower river, would acquire 
separate and exclusive advantages which the Congress could not sanction."

\section{The Austrian reply.}

Whereupon the plenipotentiaries of Austria replied "that all the efforts as well as the tendencies of their Gorernment, in commercial matters, have for their object to establish and propagate in all parts of the Empire the principles of complete liberty, and that the free navigation of the Danube is naturally comprised in the improvements which it proposes to make; but that it finds itself hampered, in this matter, by previous engagements and acquired rights which it is obliged to take into account; that its intentions, therefore, respond to the wish recorded in the preliminaries of peace; that, nevertheless, they cannot recognise in the Commission, which it is proposed to establish, an authority which could not belong to it on the Upper Danube."

\section{A Distinction.}

The first plenipotentiary of France then said: "that it is necessary, in fact, to distinguish between two solutions, equally admitted in principle, but having each of them an object perfectly distinct; that, on the one hand, the Congress ought to provide for the free navigation of the Danube throughout its whole course, upon the bases established by the Congress of Vienna; and on the other, to consult as to the means of remoring the obstacles which impede the movement of commerce in the lower part of the river and at its mouths; that it is solely this latter task which will devolve on the Commissioners whom it is proposed to appoint; but that it is not less essential to come to an understanding on the developments of the general principle, in order to complete the work which the Contracting Powers had in view in stipulating, as is said in the preliminaries, that the navigation of the Dauube and its mouths shall be efficiently secured, reserving the special positions of the riparian Powers, which shall be regulated on the principles established by the Act of the Congress of Vienna with respect to river navigation." 
It was then decided that the Austrian plenipotentiaries should present in the near future the necessary amendments to Count Walewski's draft.

\section{Austria accepts the application of the principles} TO THE WHOLE RIVER-Her AMENDMENTS.

This was done at the sitting of March 18th (Prot. 10), when Count Buol assented to the entire application of the principles of the Vienna Congress to the Upper Danube, "provided, however, that this measure be combined with the engagements previously taken bonâ fide by the riparian Powers."

$\mathrm{H}$ accordingly proposed the following amendments:

"I. The first $\S$ of Art. 2, entrusting the Sublime Porte with the execution of the necessary works at the mauths of the Danube, is replaced by: "With the view of carrying out the provisions of the preceding article, a Commission composed of the delegates of Austria, France, Great Britain, Prussia, Sardinia and Turkey, shall be charged with designating the works necessary to clear the mouths of the Danube from the sands which obstruct it." "

"In the second $\S$, relative to the dues to be collected. instead of 'fixed dues at a suitable rate may be levied on ships navigating the Lower Danube,'" Austria proposes to say: "In order . . . to facilitate the navigation at the mouths of the Danube, fixed dues at a suitable rate, may be levied, on the express condition that....' (V. $\$ 109$ II.).

"II. Arts. 3 and 4 of Count Walewski's draft are replaced by: 'III. A Commission shall be established which shall be composed of delegates of Austria, Bavaria, Wurtemberg, Servia, Wallachia, Moldavia and Turkey. It shall be permanent: (a) Shall prepare regulations for navigation and river police; (b) shall remore the legislative impediments which still prevent the application to the Danube of the arrangements of the Treaty of Vienna; (c) shall order and cause to be executed the necessary works throughout the whole course of the river.' IV. It is understood that the European Commission shall 
have completed its task, and that the river Commission shall have finished the works described in the preceding article by the letters (a) and (b), within the period of two or three years, or sooner if possible. The Congress sitting at Paris, having been informed of this fact, shall, having placed it on record, pronounce the dissolution of the European Commission."

"III. Arts. 1 and 5 of Count Walewski's draft remain unaltered."

This proposition of Austria may be considered as the certificate of birth of the European Commission.

\section{Introduction of the Prussian plenipotentiaries.}

On March 18th, during a special sitting (Prot. 11), the Prussian plenipotentiaries were introduced and presented their full powers. At the sitting of March 10th (Prot. 7) the Congress had definitively decided to invite Prussia, this Power being signatory to a convention subject to revision.

\section{The Definitive text.}

On March 26th the President began the general and definitive reading of all the stipulations adopted by the Congress (Prot. 15).

The reading was completed the next day (Prot. 16), wher: the provisions which were to become Arts. 15 to 19 of tho Treaty of Peace were adopted $(d)$, though not yet quite definitively. The text destined to become Art. 16 fixed Toultcha as the limit of the powers of the European Commission. On the 29th, the plenipotentiaries substituted "Isatcha" for it.

The Treaty of Peace was signed on March 30th (Prot. 19). This is the text of the article in question:

\section{Free navigation of the Danube and its mouths.}

"Art. 15.-The Act of the Congress of Vienna having established the principles intended to regulate the naviga-

(d) At the same sitting the plenipotentiary of Turkey declared "that the Sublime Porte would willingly make the advances necessary for the execution of the works mentioned in Art. 16."

к. 
tion of rivers which separate or traverse different States, the Contracting Powers stipulate among themselves that those principles shall in future be also applied to the Danube and its mouths. They declare that this arrangement henceforth forms a part of the public law of Europe. and take it under their guarantee."

\section{Dues and Regulations of Police and Quara'NTinl:}

"The navigation of the Danube shall not be subjected to any impediment or charge not expressly provided for by the stipulations contained in the following articles. Ir consequence, there shall not be levied any toll founded solely upon the fact of the navigation of the river, nor any duty upon the goods which may be on board of vessels. The regulations of police and of quarantine to be established for the safety of the States separated or traversed by the river, shall be so framed as to facilitate, as much as possible, the passage of vessels. Except these regulations, no obstacle whatever shall be opposed to free navigation."

120. Appointment of the European Commission.

"Art. 16.- With a view to carrying out the provisions of the preceding article, a Commission in which Austria, France, Great Britain, Prussia, Russia, Sardinia and Turkey, shall each be represented by one delegate, shall bo charged with designating and causing to be executed the works necessary, below Isatcha, to elear the mouths of the Danube, as well as the neighbouring parts of the sea, from the sands and other impediments which obstruct them, in order to put that part of the river and the said parts of the sea in the best possible condition for navigation."

\section{Dues to Be Levied.}

"In order to cover the expenses of such works, as well as of the establishments intended to secure and to facilitate the navigation at the mouths of the Danube, fixed dues, 
of a suitable rate, settled by the Commission by a majority, of votes, may be levied, on the express condition that, in this respect as in every other, the flags of all nations shall bo treated on the footing of perfect equality."

122. Appointment of the Riparian Commission.

"Art. 17.-A Commission shall be established, and shall be composed of delegates from Austria, Bavaria, the Sublime Porte and Wurtemberg (one for each of these Powers), to whom shall be added Commissioners from the three Danubian Principalities, whose appointment shall have been approved by the Porte. This Commission, which shall be permanent: (1) shall prepare the regulations for the navigation and the police of the river; $(2)$ shall remove the impediments, of whatever nature they may be, which still prevent the application to the Danube of the provisions of the Treaty of Vienna; (3) shall order and cause to be executed the necessary works throughout the whole course of the river; and (4) shall, after the dissolution of the European Commission, see to maintaining the navigability of the mouths of the Danube and of the neighbouring parts of the sea."

123. Dissolution of the European Commission.

"Art. 18.-It is understood that the European Commission shall have completed its task, and that the riparian Commission shall have finished the works deseribed in the preceding article, under numbers (1) and (2), within the period of two years. The signatory Powers, assembled in conference, having been informed of this fact, shall, after having placed it on record, pronounce the dissolution of the European Commission, and from that time the permanent riparian Commission shall enjoy the same powers as those with which the European Commission shall have until then been invested."

124. Stationaries at the mouths of the Danube.

"Art. 19.-In order to ensure the execution of the 
regulations which shall have been established by common agreement, in conformity with the principles above set forth, each of the Contracting Powers shall have the right to station, at all times, two light vessels at the mouths of the Danube."

125. The principles of Vienna and the Congress of Paris.

As already stated ( $\$ 118 s q q$.), Art. 16 expressly stipulates for the application of the principles established in 1815 by the Congress of Vienna to the Danube and its mouths. The Contracting Powers declare "that this arrangement henceforth forms a part of the public law of Europe, and take it under their guarantee."

Art. 16, § 2, determining what dues may be levied, stipulates: "that, in this respect as in every other, the flags of all nations shall be treated on the footing of perfect equality."

It thus appears as though, by common consent, the Great Powers had recognised the binding character in Europe of Arts. 108 to 117 of the Final Act of the Congress of Vienna, and declared themselves for good and all in favour of the wider interpretation of Art. 109 ( $\$ 79)$.

This, however, the Austrian plenipotentiaries did not fail to deny later on (V. $\S \S 135-136)$. Austria even tried to narrow the interpretation of the articles of 1856 , by referring to the restrictive interpretation of the article of 1815 ; while Prussia, at that time much interested in other rivers, but hardly as yet. in the Danube, maintained the restrictive interpretation of the Act of Vienna, but held that the Congress of Paris had applied a more liberal system to the Danube. And at the fifth sitting of the Conference of Berlin in 1885, the Russian plenipotentiary declared that: "In the opinion of the Imperial Government of Russia, the principles of the Congress of Vienna, as to the liberty of river navigation, have not been applied to the Danube in conformity with the spirit and letter of several essential provisions of the Final Act of that Congress. On the contrary, it dissented from the stipulations of that Act concerning the Danube." But the context (Prot. 5) showe that Count Kapnist was particularly aiming at the system of 
International Commissions, which he declared was, with reference to the Congress of Vienna, "an exceptional measure, and not at all the application of the rule" ( $\$ 273$, p. 171).

Apart from diplomatic controversies, it is plain that the Congress of Paris marks a substantial progress over the Congress of Vienna, by removing doubts of interpretation in favour of greater liberality and equality, and taking into greater account the interests of the community of nations.

But claims are seldom definitively abandoned, even though they have been publicly renounced. The Treaty of 1856 gave rise to as much discussion as the Act of Vienna had done in 1816 and thereafter. Intentions and desires repressed in Congresses assert themselves in the subsequent regulations.

From the Treaty of Paris, 1856, to the Treaty of Berlin, 1878.
A. The Act of Navigation, 1857.
B. The Public Act of 1865 .
C. The Treaty of London, March 13th, 1871.

A. The Act of Navigation, 7th Nov., 1857 (e).

126. Execution of Art. 17 of the Treaty of Paris.

The riparian Commission had, among its first duties, to draw up regulations for the navigation and the police of the river (Treaty of Paris, 1856, Art. 17). This was done in 1857.

12\%. The PRINCIPLE OF FREEDOM.

The principle of free navigation was proclaimed as follows in Art. 1:

"The navigation of the Danube from the place where that river becomes navigable as far as into the Black Sea, and from the Black Sea to the said place, shall be entirely free as regards commerce, both for the transport of goods

(e) Parliamentary Papers, Turkey, No. 29 (1878) [C.-2006], No. 6. Ratified by the Emperor of Austria, December 29th, 1857; Ratifications exchanged at Vienna, January 9th, 1858. Ibid., No. 7. Not sanctioned by the Paris Conference ( $\$ \S 138 s q q ., 143)$. 
and of passengers; obeying always the dispositions of the present Act of Navigation as well as the river police regulations."

Art. 2 abolished "all the exclusive privileges for navigating the Danube, as well as all special favours of a like nature hitherto granted to any societies or corporations or to individuals.'

Art. 3 abolished "all compulsory dues of warehousing, storing, breaking cargo, pre-emption, and others of a like nature which may have existed on the Danube."

"Consequently, the article went on, no master of a vessel can be obliged in the future, for such a purpose, to land, to unload or tranship in any port of this river or to stop against his will a certain time in any place whatever."

1:8. RESTRICTIONS IN FAVOUR OF THE RIPARIANS.

By Art. 5 "the use of the navigation from the high saras, to each one of the ports of the Danube, and from each of these ports to the high seas, is free for the ships of all nations" "which ships, the article further provides, shall be treated in all respects on a footing of complete equality.

By Art. 7, the same treatment is due to "vessels eoming from a navigable channel communicating indirectly with the Danube, or returning thither.'

Note the restrictions: "from or to the high seas," "from or to a narigable channel". . . \&e. . . . There stops the equality of treatment. The coasting navigation is reserved by Art. 8 :

"The use of the river navigation, properly so called, between the ports of the Danube without going on to the high seas, is reserved to the vessels of the riparian countries of the river."

And Art. 9 permits "everyone undertaking the navigation and belonging to one of the riparian countries . . . . to place navigation agents in the territory of another on the banks of the river, to set up there the offices and establishments necessary to the undertaking, as also to utilise the public buildings, such as the places of disembarkation, quays, \&c., on the same footing 
as the natives;" while by Art. 10, "all advantages conceded in a riparian country to the vessels of any nation whatever, with reference to the navigation of the Danube, shall be equally conceded to the vessels of all the riparian States."

In order to be admitted to the benefit of Art. 8 (coasting navigation) a vessel "must be the property either of a subject of the riparian country concerned, or of a company or society of shareholders subject to the laws of the said country and having its seat in it; it ought, moreover, to be furnished with the licence prescribed in Art. 14, and to be under the special direction of a master authorised as such under the licence prescribed in Art. 16" (Art. 11). The boat licence, Art. 15 provides, "ceases to be valid from the moment the boat no longer belongs to a subject of the riparian State by which it was granted, or to a company or society belonging to the same country;" and by Art. 17, "the licence of a master becomes invalid as soon as he ceases to be the subject of the riparian State by which his licence was granted." (See Arts. 11 to 18 generally.)

\section{SUNDRY PROVISIONS.}

Then follow articles concerning the collection of dues, the customs, the obligations of the masters of vessels, warehousing, \&c.

\section{Quarantine and pilotage.}

Art. 28 provides that " the regulations of quarantine establishments on the Danube shall be drawn up in such a way as to attain the object of a sanitary police, without uselessly obstructing the navigation." The treatment is different aceording as vessels come from the sea or navigate exclusively on the river (Arts. 29 and 30).

"Each Government shall establish a well organised service of pilotage at suitable places" (Art. 33), and "vessels navigating on the Danube are obliged to take on board legally authorised pilots, on those portions of the river where their doing so is or may be preseribed, and to submit to the regulations determined upon in this respect." 
131. Respective Powfrs of the RIPARIan Governments and of the permanent Riparian Commission.

Art. 34 states that-

"the Governments of the riparian countries reserve to themselves the right of establishing, by comnon agreement, through the permanent riparian Commission $(f)$, more detailed regulations for navigation and river police."

"The riparian Governments undertake to have carried out, each ir: so far as it is concerned, the works which the riparian Commission by common agreement shall judge necessary . . .," the cost to be defrayed by the dues collected (Art. 36).

They will refer to experts to determine these works, and the Iron Gates will be the chief object of the examination (Art. 37).

"With respect to the navigability of the river downwards from Isaktcha (Isaccea), the river Commission will act in accordance with the provisions of Art. 17, No. 4, and of Art. 18 of the Treaty of Paris of March 30th, $1856 "$ (Art. 38).

In other words it will be subjected to the permanent riparian Commission.

The riparian States engage to maintain the existing towing paths in good order, to adopt all measures necessary to facilitat landing and loading, \&c., to build sufficient storehouses, and to establish water gauges in the proper places (Arts. 41 to 43 ). Art. 44:

"The permanent riparian Commission, within the limits of its prerogatives, shall see to the execution and to the maintenance of the stipulations of the present Navigation Act."

132. The Powers examine the Act of Navigation (1858.

In August, 1858, the representatives of the Powers assembled in Paris to execute Art. 18 of the Treaty of 1856. But the examination of the Act of Navigation raised observations from the delegates of the Powers which gave rise to an important

(f) I.e., the Commission which is to succeed to the two existing conmissions: the European and the riparian Commission ( $\$ 123)$. 
discussion recorded in Prot. 18 of the sitting of August 16th, 1858.

133. The objections of the Powers.

Enumerating the modifications which he had been instructed to propose, Lord Cowley pointed out first that, whereas the articles of the Final Act of Vienna must serve as the basis for the regulations of the Danube, the following clause of the former: "The navigation . . . shall be entirely free, and, so far as concerns trade, shall not be forbidden to anyone" is omitted in Art. 1 of the latter;

(2) that the same Final Act of Vienna declares that the regulations shall be settled "in a manner uniform for all and as favourable as possible to the commerce of all nations." Now. not only are these words similarly omitted, but the Act of Navigation reserves many privileges to the subjects of the riparian States;

(3) that no mention is made, in the Act of 1857 , of the tributaries of the Danube;

(4) that Art. 5 is unnecessary if, as Lord Cowley proposes. Art. 1 is modified and Art. 8 suppressed;

(5) that this Art. 8 is not in accordance with the preliminaries of peace annexed to the first protocol of the Congress of Paris ( $\$ 107$ ), nor with Arts. 15 and 16 of the Treaty of Paris, which provide that " apart from these regulations (police and quarantine) no obstacles whatever shall be opposed to free navigation," and that "the flags of all nations shall be treated on a footing of perfect equality;" nor is Art. 8 in accordance with Art. 5 of the Treaty of Paris, 1814, or with the Act of the Congress of Vienna which is based on it; it is, moreover. irreconcilable with the interpretation which Austria herself gave to the Act of Vienna, when in 1849 , she entered into an agreement coneerning the navigation of the Pô $(g)$.

(g) The treaty between the governments of Austria, Modena and Parma, signed at Milan, July 3rd, 1849, provided in the first article that: "The navigation of the Pô shall be free and exempt from all burden along the whole tract of the territories of the States signing, as far as the Adriatic Sea, and it shall not be interdicted, nor shall impediments be interposed 
(6) that Art. 9, which gives exclusive privileges to traders "belonging to one of the riparian countries," is not in harmony with the spirit of either the Congress of Vienna or that of Paris:

(7) that Arts. 11 to 18 are in fact calculated to safeguard tho monopoly created by Art. 8 rather than to provide for public safety. They should be suppressed together with Art. 8 and the last $\S$ of Art. 35 ;

(8) that the provisions concerning quarantine are too vague and may lend themselves to unjustifiable restrictions;

(9) Art. 34 reserves to the riparian Powers the right of modifying the existing regulations or drawing up others. The British plenipotentiary - the protoool says-"expresses his conviction that such alterations could not be effected without the consent of the signatory Powers of the Treaty of Paris;"

(10) Art. 45 says that: "As regards all the points not regulated by the present Narigation Act, the treaties, conventions and agreements already existing between the riparian States remain in force." The British plenipotentiary thinks it necessary to add: "provided that they contain nothing incompatible with the principle of free navigation established by the Treaty of Vienna."

Thus the British plenipotentiary clearly took up a position in favour of the general interest against those who were tryingnot without success-to narrow and attenuate, to their own profit, the beneficent principles of the Congress of Vienna. He was supported by the French, Sardinian, Russian, and even Prussian plenipotentiaries.

'The French plenipotentiary insisted that all the tributaries

in any way, to any person whatever, with reservation of the regulations which may be now or hereafter determined with the common consent of those States, and always in the sense mast favourable to the development of the commerce of all nations.

"In like manner the navigation of the streams joining the Pô, below the mouth of the Ticino, shall also be free, (1) if they are within the limits of any of the contracting States, (2) from the point where they leave the State in which they rise, as far as and including their confluence with tho Pô, in which course, if there should exist any simple Navigation Dues, theie shall not be greater for foreigners than for natives." 
of the Danube should be open to the navigation of all Powers. His Government was all the more entitled to claim it, because "with respect to the eoneession which had been granted by the Moldavian Government to a Freneh company for the improvement of the Sereth, the French Government, in consequence of a formal demand of Austria to this effect, and after a correspondence exchanged with this Power and the Porte, consented to eaneel this privilege."

\section{Thi. Defence of the ACt of Nivigation.}

The defence of the Act of Navigation was undertaken by Baron Hübner, the Austrian plenipotentiary, supported by his Ottoman colleague. It was based mainly on the restriative interpretation of the principles adopted by the Congress of Vienna, to which we shall devote the next section. But the Austrian plenipotentiary, moreover, set up in its favour the restrictive clauses inserted in the regulations of the Rhine and the Elbe-which regulations the riparian States had several times modified without any intervention on the part of the Powers. Besides, from the riparian States reserving the coasting navigation to their own subjects, it did not follow that it was intended to prohibit all non-riparian flags from engaging in the trade of the river. Finally, Baron Hübner defended Arts. 11 to 18, Art. 20 and Art. 34, all of which were, in his opinion, justified means of efficaciously providing for the maintenance of order and the exigencies of publie health, whose restriction or limitation would be incompatible with the sovereign rights of the riparian States.

As to the Pô, concerning which Austria had insisted on the liberal interpretation of the maxims of the Congress of Vienna, the Austrian plenipotentiary omitted to refer to it. He preferred to speak of the Rhine; but, as Lord Cowley pointed out, from the fact that the regulations for the navigation of that river had not been objected to, it could not be inferred that they were agreeable to the principles adopted by the Congress of Vienna. 
135. Austrian interpretation of the PRINCIPLES OF THe Congress of Vienna.

Contrary to the opinions of the French, British, Russian, Sardinian and Prussian plenipotentiaries, the Austrian plenipotentiary declared himself convinced that the scheme of the riparian Commission was in all points in conformity with the Treaties of Vienna and Paris. Indeed, he explained, the principles adopted by the Congress of Vienna, and the stipulations of the Treaty of Paris, 1856, are alone binding on the riparian Powers of the Danube. Now, what are these principles, these stipulations?

First, it is impossible to deduce from the text of Art. 109 of the Final Act of Vienna, that free navigation is granted to the flags of all nations. "But even admitting-which the Austrian plenipotentiary is far from doing - that this article is susceptible of various interpretations, where, if not in the protocols of the Commission appointed to consider the questions of river navigation, and composed of members of this very same Congress $(h)$. should the true interpretation be sought? Let us refer, says Baron Hübner, to these protocols.

"On February 2nd, 1819, at the first meeting of this Commission. the Due de Dalberg, the French plenipotentiary, proposed: 'Art. 1.-The Rhine . . . . shall be considered, as far as regards commerce and navigation, as common between the States which it divides or flows through. Art. 2.--The navigation . . . . shall be absolutely free, and shall not be forbidden to anyone so long as he conforms to the regulations, \&e. (§ 49).

"At the second neeting (February 8th), Lord Clancarty, referring to the Treaty of Paris of 1814, 'proposed,' says the protocol, 'on the basis of the Treaty of Paris, and in order to. extend the freedom of the Rhine navigation to all nations, to substitute for the wording suggested by the French plenipotentiary the following: "Art. 1.-The Rhine shall be entirely free to the commerce and navigation of all nations." ,

"This proposal not having boen acted on, he revertod to it

(h) On the romposition of the Committee, see $\$ 47$. 
in the seventh meeting of the Conference (March 3rd). 'Nevertheless, says the protocol, the other members of the Commission were of opinion that there were no grounds for making this amendment, since . . . (i) the arrangements of the Treaty of Paris had for their object merely the preservation of the navigation from such impediments as a conflict between the riparian States could bring about, and not the granting to all the subjects of non-riparian States an equal right of navigation with that enjoyed by the subjects of the riparian States, and in return for which theie would be no reciprocity' ( $k$ ).

"Such," declares Baron Hübner, "was the opinion of the authors of the Act of the Vienna Congress; such is the interpretation they have themselves given to their own work, and especially to Art. 109 when they were engaged in drawing up the bases of the regulations for the Rhine. The arrangements which to this day regulate the navigation of this river do not depart therefrom; and if they are in conformity with the principles of the Act of the Vienna Congress (a point which has never been disputed), the Act of the navigation of the Danube is drawn up in a far more liberal spirit, as can be proved by comparing the two regulations."

136. Austrian interpretation of the stipdlations of the Treaty of Paris.

"The Austrian plenipotentiary went on to examine the Treaty of Paris. This Treaty, he said, places at the head of the article relative to the navigation of the Danube the fundamental stipulation that the principles of the Act of the Vienna Congress shall be in future applied to the Danube. From that instant the Act of the Congress of Vienna has become the rule; the exceptions should have been (as.indeed they actually are) expressly mentioned in the Treaty of Paris. But the Act of the Vienna Congress maintains the distinction between riparian and non-riparian States, which is not done away with in the Treaty of Paris. The special privileges of the riparian

(i) The words omitted by Baron Hübner will be found in $\$ 53$.

(k) See $\$ 53$ for more details and greater precision. 
Powers dare bes expressly rosted in the preliminaries of the

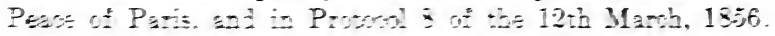

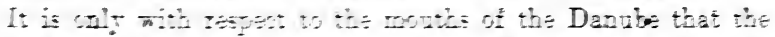

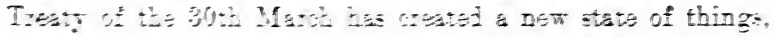

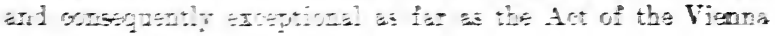

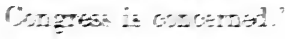

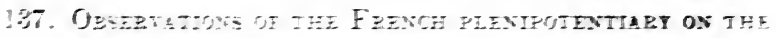

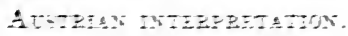

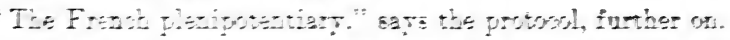

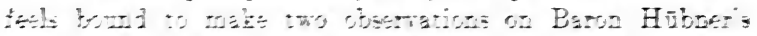

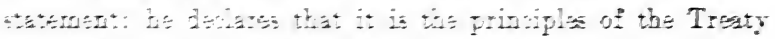

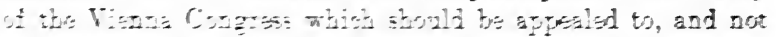

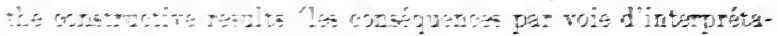

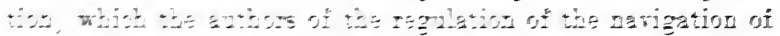

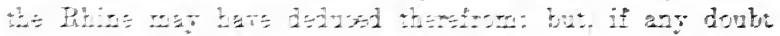

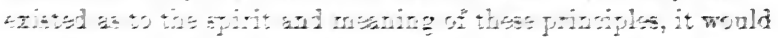

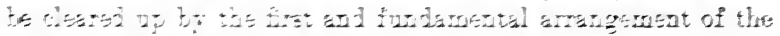

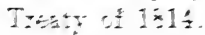

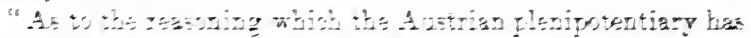

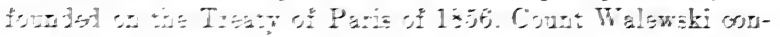

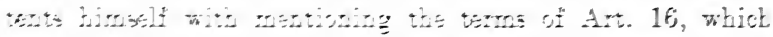

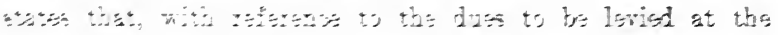

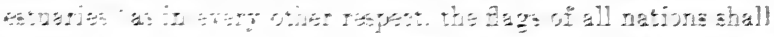

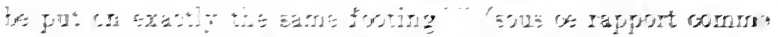



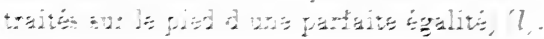

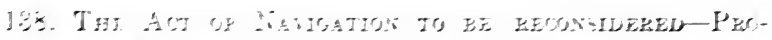

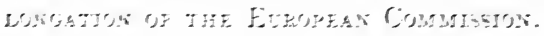





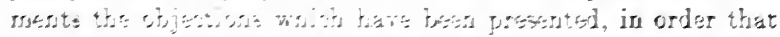

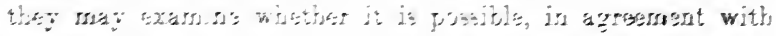

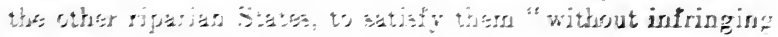

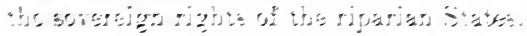

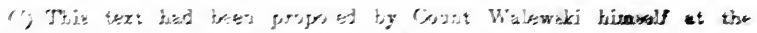

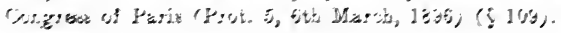


Such an examination will be long. It will las: saszerl months. Therefore the Auszian flenirutentiary gagses w ast the European Commision to arrange for the wmgetion of its work in a tew months. It will then ba gnosito to esamiz. at the same time the wor's of the two comarisins. to prowoun the dissolution of the European Commision. and. in arandance with Art. 1S. to transmit its powen to the permacint riparian Commision.

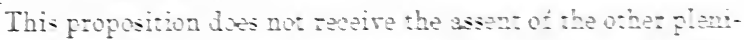
potentiaries who, before pronouning the Bisulution if ite

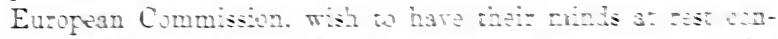
cerning the tendensits of the riparian Commisson. Finaly. after much resisan on the part of the Austian planicoten-

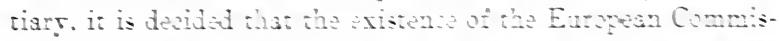



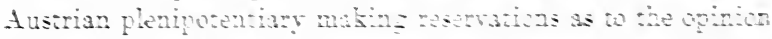

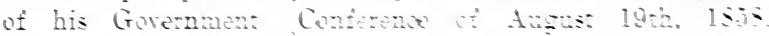
Prot. 19!



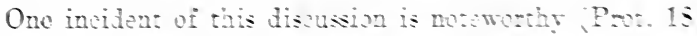
Count Kirstem hoving stated that " it should be chaty

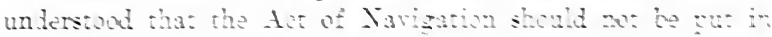

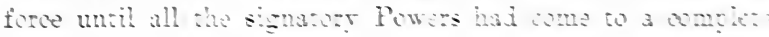

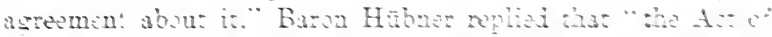

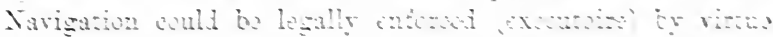



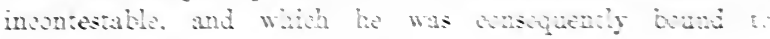
miniain.

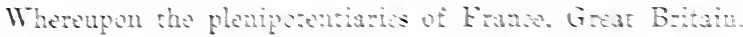


question has refereme slaty th the exantion of the Theatios. and in no way interfores with the riste of strewteny." In

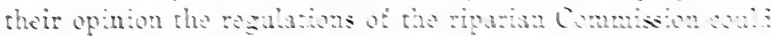
not be lesally entored mail all the stomaty Fowers has ame to an understandins about it.

The Uttoman plemipotentiser asted me to spply the Ac: 
until an agreement had been reached. The Austrian plenipotentiary reserved for his Government the eomplete exercise of its right $(\boldsymbol{n})$.

\section{Six additional articles.}

The Act of Navigation was re-examined, and on March 1st, 1859, the delegates of the riparian States gave their adhesion to six additional articles (Turkey, C.--2006, No. 9). This is a summary of the concessions made:

I. Vessels of all nations coming from or going to the high seas may transport passengers and merchandise from any port of the Danube to any other port of the river, in the direction of their voyage (cabotage accidentel).

II. Each riparian Government is free to grant on the part of the river within its territory what facilities it pleases', provided they are not contrary to the stipulations of the Act.

III. Measures of quarantine are more or less defined and their application is restricted.

IV. Pilots of all nations may be admitted under the same conditions with those of the riparian countries. The tariff of compulsory pilotage shall be periodically submitted to the riparian Commission.

V. No stipulation can be maintained in force which is inconsistent with the principles established by the Treaty of Vienna.

VI. The system established by the Act of the Congress of Vienna shall be applied to the affluents of the Danube, according to the tenour of Art. 110 of the said Act and by a special convention to be concluded between the Governments joint owners of the river banks.

No more than the Act itself elaborated by the riparian Commission did these stipulations obtain the assent of the Powers.

(n) The Act seems to have been applied on the section between Ulm and the Iron Gates in consequence of an agreement between Austria, Bavaria and Wurtemberg (Fauchille, Manuel de D. I., $§ 528$ ). 


\section{B. The Public Act, 1865.}

141. The work of the European Commission-The Public $\mathrm{Acr}$.

No sooner had the European Commission been constituted at Galatz on November 4th, 1856, than it set to work; but its task was no easy one. Besides many technical difficulties which had to be overcome to make the river accessible to navigation from the sea, it was necessary-in order to prevent the activity of the Commission from being constantly hampered and checked-to put an end to a true state of anarchy which tho abscner of authority had permitted to develop there. In the fulfilment of this task, the Commission obtained the assistance of the Sultan, to whom the Delta had been restored; but it was thus led-in addition to its hydrotechnical studies-to issue regulations for the security of navigation and the police of tho river.

We have seen how the work of the riparian Commission had little satisfied the Powers ( $\$$ 132-140).

The work of the European Commission, on the contrary, was much appreciated; and the plenipotentiaries marked their satisfaction by prolonging the duration of the Commission. In 1865 , they decided to en low it with a kind of Charter or Public Act determining its rights and duties (add $\S 162$ ). After nine years' work, the Commission has succeedod, recites the preamble, " in improving the navigation considerably by the construction of two piers at the mouth of the Sulina branch, which have had the effect of admitting into this embouchure vessels of a large draught of water-by the execution of works of improvement and dredging in the course of the same branch-by raising wrecks, and establishing a system of buoys-by the erection of a lighthouse at the mouth of the St. George-by the institution of a regular lifeboat service, and by the creation of a seamen's hospital at Sulina, lastly, by the provisional regulation of the different services connected with the navigation between Isatcha and the sea."

K. 


\section{Analysis of the provisions of the Public Act.}

The provisions of this Public Act, of which we shall give a succinct analysis, were agreed upon at Galatz on November 2nd, 1865, by the plenipotentiaries of the Powers signatory to the Treaty of Paris, 1856 (Turkey, C-2006, No. 11).

The works and establishments created for the use of the navigation of the Danube shall never be turned aside from their object and use for any motive whatever. They are to this end placed under the guarantee and protection of international law. They shall be administered exclusively and without any interference whatever by the European Commission which may give them the necessary development (Art. 1).

The exclusive authority of the European Commission is to extend over the works for the improvement of the mouths, and the branches of Sulina and St. George (Arts. 2, 3).

The Sublime Porte shall lend the Commission all the requisite assistance and co-operation, and leave at its disposal all the necessary ground (Arts. 4 and 5 ).

No works can be undertaken by the territorial authority or anybody whatever in the ports of Sulina and St. Goorge or on the banks, without the authorisation of the Commission (Art. 6).

The navigation of the mouths of the Danube is governed by the "regulation of navigation and police" enacted by the European Commission. This regulation is binding as law, not only in what concerns the river police, but also for the judgment of civil eases arising from the exercise of navigation (Art. 7).

The authority over, and the supervision of, the navigation on the Lower Danube belong to the Inspector-General of the Lower Danube and the Captain of the Port of Sulina. I'hese two agents, named and paid by the Sublime Porte, pronounce sentence in the name of the Sultan, but act under the superintendenee of the European Commission (Art. 8).

Their authority extends to all flag's without distinction (Arts. 9 and 10).

The carrying out of the regulation is ensured by the vessels 
of war stationed at the mouths of the river, in conformity with Art. 19 of the Treaty of Paris, 1856. Each naval force acts upon the vessels of its own nationality (Art. 11).

Then follow provisions concerning the navigation dues intended, (a) by priority and preference, to repay the loans contracted-or to be contracted-by the Europiean Commission; (b) to cover the expenses of administration and maintenance. of the works and establishments; (c) to liquidate the advances made by the Sublime Porte;-any surplus being held in reserve to meet the expenses that may be incurred for certain works (Art. 14); the revision of the tariff of dues every five years. with a view to diminishing, if possible, the burdens imposed upon the navigation (Art. 15); the administration of the Navigation Cash Office of Sulina (Art. 16), \&c.; the rules of quarantine (Arts. 18 to 20), and finally an article by which-

"The works and establishments of all kinds ereated by the European Commission of the Danube, or by the authority which shall succeed it, in execution of Art. 16 of the Treaty of Paris, particularly the Navigation Cash Office at Sulina, and those which it may hereafter create, shall enjoy the neutrality stipulated by Art. 11 of the said Treaty, and shall be, in ease of war, equally respected by all the belligerents.

"The benefit of this neutrality shall be extended, with the obligations which spring from it, to the general inspection of the navigation, to the administration of the Port of Sulina, to the staff of the Navigation Cash Office and Seamen's Hospital, and lastly, to the technical staff charged with the superintendence of the works." (Art. 21) (o).

(o) It may be noted that no analogy exists between the organisation established on the Lower Danube and that established on the Rhine in 1804 ( $\$ 35$ ). There are a few resemblanses of datail, but the two institutions are fundamentally different. For the Rhine, in 1804, two sovereign riparian Siale; have resourse to a common administration in what concerns the collection of navigation due, the maintenance of police and the keeping of the river in repair. Here, non-riparian powers intervene, and in agreement with Turkey, which acts in virtue of its rizht of suzerainty over the river bordering Principalicies, create a European organization which has 


\section{The Conference of 1866 (March to June).}

In 1866, the plenipotentiaries of the Powers, again assembled in Paris in order to deal with the united principalities of Moldavia and Wallachia, seized the opportunity of regulating various questions relative to the navigation of the Danube.

They had (1) to ratify the Public Act. This was done in a special protocol inserted in the third protocol of the Conference of March 28th.

(2) To examine the question of the duration of the European Commission. Hitherto, the powers of the European Commission had been prolonged without a fixed limit. It was now proposed, while adhering to the principle that it is neassary to allow it to complete its work, to fix a limit of five years. The adhesion of Austria, France, Great Britain, Italy, Prussia and Turkey was notified at the Conference of April 24th. Russia toc gave its adhesion, but pointed out that the five years should be considered as the utmost limit (Prot. 6).

(3) To decide on the extension of its power's to Ibraïla. The project of extending to Ibraïla the action and authority of the European Commission was put forward by the British delegate to that Commission. The British plenipotentiary expounded the advantages of such an extension in a note which he read at the Conference of March 25th (Prot. 3). The plenipotentiaries of France, Italy and Prussia gave their adhesion on May 2nd (Prot. 7). But at the Conference of May 17th' (Prot. 8), the Prussian plenipotentiary declared that his adhesion must not be understood in an absolute sense. "Tha favourable opinion of his Government might be modified in consequence of the difficulties that the execution of this project

authority over the Lower Danube, improves the navigation, builds lighthouses, quays, \&c., and coliests dues calculatel to defray the expenses incurred for the sake of the navigation. Vessels of war are stationed at the mouths to ensure the exe ution of the ordars issued by the Commission or its officers. The only homage renderel to the suzarainty of the Su'tan consists in his approving the nomination of the officials and in their sentences being pronounced in his name. We shall see, in course of time, after the Congress of Berlin, in 1878, this European organisation transformed to the extent of besoming a creation quite unique in history ( $\$ 162)$. 
might encounter on the part of the riparian States of the Lower Danube." The proposal was provisionally rejected $(p)$.

(4) To see whether any agreement is possible concerning the Act of Navigation. The Act of Navigation drawn up by the riparian Commission in 1857 ( $\$ 126$ to 131) not having been ratified, the transformation of the riparian into a pormanent Commission on the dissolution of the European Commission remained pending.

The Austrian plenipotentiary was asked whether he was able to indicate with some precision the intentions of lis Government as regards the observations made by Lord Cowley at the Conference of 1858 ( $\$ 133$ ). Prince Metternieh adopted a dilatory attitude which made all agreement impossible.

144. Loan guaranteed by the Powers (April 30th, 1868).

In 1856, Turkey had agreed to advance to the European Commission the nocessary sums for the execution of its works ( $\$ 117$, note). By the Public Act, 1865, the Commission was organised on the principle that the navigation dues were to provide the necessary funds, and to contribute to the payment of interest and the redemption of loans (cp. \$ 142).

"Having recognised the necessity of putting the European Commission in a position to contract a loan on advantageous terms, and by this means to complete the works undertaken, or to be undertaken, without imposing too heavy burdens on the vessels of all nations which frequent the Lower Danube . . . ." the Powers signatory to the Treaty of 1856. except Russia, engaged, by a eonvention signed at Galatz on April 30 th, 1868, to guarantee the interest and sinking fund

( $p$ ) This proposal did not meet with greater success at the Conference of London in 1871. It is only in 1878, at the Congress of Berlin, that the idea was ascepted, but Galatz was then taken as the limit and not Ibraïla. Finally, in 1883, the extension to Ibrailla was resolved upon.

By fixing on Isaccea as the limit of the jurisdiction of the European Commission, the Treaty of Paris marked the intention of confining European action to the Delta of the river. This can be justified from a political point of view; but from a technical point of view, the extension to Ibraïla has its justification in the fact that it offers considerable advantages and facilities to maritime navigation to that port. 
of a loan, redeemable within twelve years to run from January 1st, 1871, the date at which the payment of the loan would have been completed by the lenders (Turkey, C.-2006. No. 14) $(q)$.

This explains Art. 4 of the Treaty of London, March 13th. 1871, prolonging the duration of the European Commission until April 24th, 1883, when the loan would have to be redeemed.

The abstention of Russia was due to the fact that she was beginning to consider herself no longer bound by the Treaty of $\mathrm{Paris}$ which, in her opinion, restriated her sovereign rights. Russia was thinking particularly of the Black Sea, but the regime of the Danube is closely connected with the régime of that sea.

\section{The Treaty of Londox (March 13Th, 18זl).}

\section{The Treaty.}

The Conference at which the above mentioned measure was taken, ought, like the former Conferences, to have taken place in Paris. But this was rendered impossible by the FranooPrussian war, and the plenipotentiaries assembled in London.

Their principal object was to revise the stipulations of the Treaty of Paris relative to the Black Sea. They also dealt with the question of the Danube. They prolonged the duration of the European Commission (see $\S 144$ ); they rejected the proposition of extending its action to Ibraïla (Prot. o. March 13th) (\$ 143). Count d'Apponyi had previously (Prot. 3) proposed an agreement between Austria and its coriparians on the means of procuring the necessary funds for the execution of the works intended to be undertaken at the Iron Gatas. This proposition was not admitted as such (Prot. 5). The Conference contented themselves with authorising the collection of a provisional tax with a view to defray -

(q) See 31-32 Vict. c. 126, July 31st, 1868: "An Act to enable Her Majesty the Queen to carry into effect a Convention made between H.M. and other Powers relative to a loan for the completion of works for the improvement of the navigation of the Danube." 
ing the expense of the works, but they abstained from declaring that these works were to be undertaken (see Art. 6 of the Treaty, Appendix IV., 337).

The Austrian plenipotentiary was more successful seven years later, at the Congress of Berlin, where he obtained that the execution of the works should be entrusted to Austria ( $\$ \S 149$, 153,159 ).

We may lastly note a provision confirming the neutrality granted to the establishments and personnel of the European Commission. This provision was due mainly to the fact that Russia had once more obtained the right of disposing freely of her naval forces in the Black Sea.

146. The regulation of the European Commission for the Navigation and Police of the Lower Danube.

While the Powers persisted in refusing to ratify the regulation drawn up by the riparian Commission ( $\$ \S 126$ to 131 ), they gave a ready assent to the regulation of the European Commission annexed to the Public Act of November 2nd, 1865. This regulation, applicable to the Lower Danube, was revised in 1870 , and again in 1875 , November 10th, as was also the tariff of dues to be levied at the Sulina mouth $(r)$.

This regulation puts all flags alike under the control of the Inspector-General of the Navigation of the Lower Danube and of the Captain of the Port of Sulina; both acting under the superintendence of the European Commission (Art. 1).

To ensure the execution of the regulation, each naval force stationed at the mouths (in accordance with Art. 19 of the Treaty of Paris)-

"acts upon the vessels of its own country, or upon those whose flag it is called upon to protect, either in virtue of Treaties or usage, or in consequence of a general or special delegation.

"In the absence of a vessel of war qualified to interfere,

(r) We may mention here the revision of the regulation on May 19th, 1881, and on November 10th, 1911. The latter will be found in De Martens, edited by H. Triepel, 3rd series, IX., 1st livraison, 1916. 
the authorities can have recourse to the vessels of war of the territorial Power" (Art. 21).

The Inspector-General is assisted by several superintendents distributed over different sections of the Lower Danube (Art. 3).

The Captain of the Port of Sulina is charged with the police of the port and roadstead of Sulina (Art. 4).

"The masters of merchant vessels, to whatever country they belong, are bound to comply with the orders given them in virtue of the present regulation by the InspectorGeneral, by the Captain of the Port of Sulina, or by agents placed under their orders" (Art. 5).

When claimed by one of the parties, or when no other competent authority is on the spot, the Inspector-General and the Captain of the Port of Sulina may "decide sumnarily on disputes arising between captains and their crews, calling in the aid of two captains of the same nationality as the contending parties, or in default of them, of two other captains" (Art.6).

These two officials are also competent to decide on disputes relative to pilotage and to inflict fines for infringing the regulations.

The other numerous provisions (Arts. 7 to 199) pertain to technical details.

D. The Congress of Berlin (June 13th to JuLY 13TH, 1878).

147. Preliminary Treaty of San Stefano.

The Russo-Rumano-Turkish war of 1877 brought about further modifications of the Danubian régime.

The preliminary Treaty of San Stefano between Russia and Turkey (February 19th-March 3rd, 1878) contained the two following clauses:

"Art. 12.-All the Danubian fortresses shall be razed. There shall be no strongholds in future on the banks of this river, nor any men-of-war in the waters of the Principalities of Rumania, Servia and Bulgaria, except the usual 
'stationaries' and the small vessels intended for river police and custom-house purposes.

"The rights, obligations, and prerogatives of the International Commission of the Lower Danube are maintained intact."

"Art. 13.-The Sublime Porte undertakes to render the passage of Sulina again navigable, and to indemnify the private individuals who have suffered loss by the war and the interruption of the navigation of the Danube, applying for this double charge a sum of five hundred thousand francs from the amount due to the Sublime Porte from tho Danubian Commission."

\section{The Congress of Berlin.}

On the invitation of Germany, the Powers signatory to the Treaty of $18 \tilde{6} 6$ decided, with a view to promoting the general interest and the peace of Europe, to examine the Eastern Question. Hence the Congress of Berlin, 1878.

\section{Proposition of Baron Haymerlé.}

During this examination, and although Arts. 12 and 13 of the Treaty of San Stefano did not modify in any respect the régime fixed upcn for the Danube, the Austrian plenipotentiary. Baron Haymerlé, proposed to the Congress to substitute for the said articles the following stipulations (Parl. Pap., Turkey, No. 39 (1878) [C.-2083]) $(s)$ :

" 1 . In order to ensure, by a fresh guarantee, freedom of navigation on the Danube, the whole section of the river from the Iron Gates to its mouths in the Black Sea is declared neutral. The islands situated in this section

(s) Lord Beaconsfield had observed that Arts. 12 and 13 of the Treaty of San Stefano ought to have again stipulated for the free navigation of the Danube. Prince Gorichakoff, on the other hand, declared that he did not anderstand why the fast that Russia was again in possession of the Kilia branch made new stipulations necessary. Prince von Bismarck was of the same opinion. But Austria was uneasy. Hence, the Haymerle proposition. (Cp. $§ 150$. 
and at the mouths (the Islands of Serpents), as well as the banks of the river, are comprised in this neutrality.

"As a consequence, the fortifications which exist there shall be razed, and the erection of new ones will not be permitted. All vessels of war are excluded from the abovenamed section of the river, with the exception of such vessels of light draught as are intended to be employed for river police and the Customs. The stationaries at the mouths are retained, but they will not be able to ascend tho river beyond Galatz.

"2. The European Commission of the Lower Danube is maintained in its functions, which it will exercise from Galatz down to the sea. Its duration will extend beyond the year 1883, until a fresh agreement is concluded. Its rights, obligations, and prerogatives are preserved intact. 'The immunities which are enjoyed by its establishments, its works, and its staff, in virtue of existing Treatios, are confirmed.

"In the exercise of its functions, the European Commission will be independent of the authority of the State to whose territory the Delta of the Danube belongs; it will have its own signs and marks upon its vessels and its establishments; it will itself select and pay its functionaries. Its financial obligations will form the subject of a new regulation, and the Statute of its organisation will be subjected to a revision in order to harmonize with tho new circumstances.

"In addition to the States which take part in the European Commission in virtue of the Treaty of Paris, Rumania will be represented in it by a delegate.

" 3 . The regulations touching the navigation and the river police below the Iron Gates will be in conformity with thase which have been, or which shall hereafter be, introduced by the European Commission in regard to the portion below Galatz. A commissary delegated by the European Commission will watch over the execution of these regulations. In the portion between the Iron Gates and Galatz, commeree and navigation shall not suffer from 
any special taxation which would have the effect of favouring commerce and conmunications by land to the prejudice of those connected with the river.

" 4 . In modification of Art. 6 of the Treaty of London of the 13th March, 1871, the execution of the works destined to remove the obstacles which the Iron Gates and the Cataracts place in the way of navigation is confided to Austria-Hungary. The riparian States of this portion of the river will grant every facility which may be required in the interest of the works.

"The stipulations of Art. 6 of the Treaty cited above, relating to the right of levying a provisional tax destined to cover the expenses of the works in question, are maintained with respect to Austria-Hungary" (Prot. 11, July 2nd, 1878).

150. EXCHANGE OF VIEWS RELATIVE TO THIS PROPOSITION.

These stipulations, in the President, Prince von Bismarck's opinion, seemed, by their extended character, in excess of the proper task of the Congress, but neither Prince von Bismarck nor Lord Salisbury objected to their being discussed. Count Schouvalow, the Russian plenipotentiary, on the contrary, declared that he could not see their point at all. Whereupon Count, Andrassy explained that it was an amendment "necessitated by the new situation resulting from the acquisition of the Dobrutcha by Rumania, and of Bessarabia by Russia.. . . " Prince Gortchakoff then contested the necessity of new provisions, sinoe the Russian plenipotentiaries had formally declared that the retrocession of Bessarabia could not influence in any way the liberty of the Danube (Prot. 11).

\section{Provisional examination of Art. 12.}

No agreement seemed at the time passible, and the Congress contented itself with provisionally examining Art. 12 of the Treaty of San Stefano, which was amended by the addition of the words: "the Russian Empire" to the riparian States. The principle of the admission of Rumania into the European Commission was accepted, and Art. 13 was suppressed. 


\section{Counter-proposition of Count Schouvalow.}

At the next sitting, on July 4th (Prot. 12) Count Schouvalow opposed to the Austrian proposition the following one:

" 1 . In order to protect by a fresh guarantec the liberty of navigation of the Danube, which is recognised as of European interest, the principles proclaimed by the Final Act of the Congress of Vienna of 1815, and applied to the Danube by the Treaties of 1856 and 1871 , are declared to be confirmed and maintained in their full and entire vigour, under the guarantee of all the Powers.

" 2 . The fortifications which are situated on the course of the river, from the Iron Gates to its mouths, shall be razed, and no new ones shall be erected. All ships of war are excluded, with the exception of small vessels intended for the river police and for the custom-louse service. The stationaries at the mouths of the river are maintained. but they are not to ascend the river above Galatz.

"3. The European Commission of the Danube is maintained in the exercise of its functions. All the International Conventions, and all the Acts guaranteeing its rights, prerogatives, and obligations, are confirmed.

"4. The Public Act of the 2nd November, 1865, relative to its organisation, shall be revised, so as to be in harmony with present circumstances.

"This task shall be confided to a special Commission to which Commissioners of all the riparian States shall be admitted, and the works shall be submitted to the examination and to the definitive sanction of a Conference of the representatives of the Signatory Powers."

153. Vote on the principles. Adoption of Arts. 52 to 57 of the Treaty of Berlin.

As it now appeared that an agreement had brocome possible on several points, the authors of the two propositions met together with a third delegate in order to come to an agreement. and it was decided to vote, not on the text of the propositions, but on the principles embodied in them, leaving to a drafting 
committec (comité de rédaction) the task of giving the articles their definitive shape and wording.

In these circumstances the Austrian proposition was adopted with some slight modifications, and at the sitting of July 10th (Prot. 17) the Congress approved the definitive wording of Arts. 52 to 57 of the Treaty of Berlin, July 13th, 1878, to the following effect:

154. No fortresses. No war vessels below the IroN Gates.

"Art. 52.-In order to increase the guarantees which ensure the liberty of the navigation of the Danube recognised as being of European interest, the High Contracting Parties determine that all fortresses and fortifications existing on the banks of the river from the Iron Gates to its mouths shall be razed, and that no new ones shall be erected. No vessel of war shall be allowed on the Danube below the Iron Gates with the exception of light vessels carrying on the service of the river police and of the Customs. The stationaries of the Powers at the mouths of the Danube may, however, ascend the river as far as Galatz."

155. Rumania represented in European Commission. Extension of its powers to Galatz.

"Art. 53.-The European Commission of the Danube, in which Rumania shall bo represented, will continue in the discharge of its duties, and will henceforth exercise them as far as Galatz in complete independence of the territorial authority. All the Treaties, arrangements, acts, anci decisions relating to its rights, privileges, prerogatives, and obligations are confirmed."

156. Prolongation of the European Commission.

"Art. 54.-One year before the expiration of the term assigned for the duration of the European Commission the Powers shall come to an agreement with regard to the 
prolongation of its powers and the modifications which it may be thought necessary to introduce."

157. Thi European Commission to frame regulations for the Navigation between the Iron Gates and Galatz.

"Art. 55.-The regulations respecting navigation, river police and supervision from the Iron Gates to Galatz shall bo elaborated by the European Commission, assisted by delegates of the riparian States, and made to harmonize with those which have been or may be issued for the section of the river below Galatz."

158. Lighthouse on Isle of Serpents.

"Art. 56.-The European Commission of the Danube shall come to an arrangement with the proper authority for maintaining the lighthouse on the Isle of Serpents."

159. Execution of woriss at the Iron Gates añd the Cataracts entrusted to Austria-Hungary.

"Art. 57:-The execution of the works which have for their object the removal of the obstacles which the Iron Gates and the Cataracts place in the way of navigation is entrusted to Austria-Hungary. The riparian States of that part of the river shall afford every facility that can be required in the interest of the works."

159a. Provisional tax maintained in favour of AustriaHungary.

"The provisions of the VIth Article of the Treaty of London of the 13th March, 1871, relating to the right of levying a provisional tax in order to cover the cost of these works, are maintained in favour of Austria-Hungary."

160. Maintenance of Treaties of 1856 and 1871.

"Art. 63.-The Treaty of Paris of March 30th, 1856, as well as the Treaty of London of March 13th, 1871, 
are maintained in all such of their provisions as are not abrogated or modified by the preceding stipulations."

\section{A NEW RÉGIME.}

The chief result of these provisions is that, besides the regime of the European Commission, which is confirmed and extended to Galatz, a new régime is created on the section between Galatz and the Iron Gates. We shall see further on whether these measures really have for their sole object the improvement of navigation, or whether political objects have not exercised their influence.

162. The Additional Act of May 28th, 1881.

Now that Art. 53 of the Treaty of 1878 authorised the European Commission to act henceforth "in complete independence of the territorial authority," a revision of the Public Act of November 2nd, 1865, was imperatively necossary (§ 142).

The modifications adopted were embodied in an Additional Act signed in 1879, but ratified only on May 28th, 1881 (Prot. of Europ. Comm. of Danube, Nos. 353 and 384).

According to the provisions of this Additional Act, the European Commission becams a kind of "moral person of public International law." Over the whole part of the river subject to its authority, it acts, so to say, as a sovereign authority, from the point of view of navigation. It appoints, pays. and dismisses its functionaries. It chooses them without distinction of nationality. They take an oath to it (prêtent serment entre ses mains). Disputes are settled in its nam (Art. 2). It exercises financial control (3). It provides for the maintenance of lighthouses ( 5$)$. It undertakes works in the river without referense to the territorial authority. The sanitary regulations are to ba established in agreement with the European Commission by the international council established to that effect in Bucharest (6). The Commission possesses ships, a recognised flag, and its persomnel enjoys special protection. Art. 8 describes their distinctive badge and flag fixed upon by common agreement "in order to ensure at all times to 
the staff, as well as to the property and works of the European Commission, the benefits of neutrality guaranteed to then by Art. 21 of the Public Act of 1865, and Art. 7 of the Treaty of London, 1871."

To characterise it henceforth, one may say of the European Commission that it is a syndicate ( $\$ \S 99$ and 103) entirely! independent of the sovereign authority over the territory in which it is situate (Rumania), and which, as a mandatory of the Powers, acts as a deliberating and executive body, and even, to a certain extent, as a judicial authority, within the limits of its mandate which aims at effectually ensuring the free navigation of the Lower Danube. This syndicate has its own financial system and draws its revenue from the navigation dues. Within its proper sphere, it has quasi-sovereign powers, and as a sanction to its authority, it may call upon the warships stationed by the Powers at the mouths of the Danube to repress infringements of its regulations.

\section{The attitude of Rumania.}

Rumania did not look favourably on this Additional Act. It was difficult for her to adhere to provisions which permitted the European Commission to act "in complete independenco of the territorial sovereign authority"-viz., her own authority $(s)$. She yielded, however, though she never ceased to combat with energy the endeavours of Austria-Hungary to. establish her supremacy over the Lower Danube.

\section{The "Commission mixte."}

164. Austria's objects on the sfction between the Iron Gates and Galatz.

Austria-Hungary had good reasons for being satisfied with the Treaty of 1878, for it granted her, with respect to tho works to be effected at the Iron Gates, what she had striven, but in vain, to obtain in 1871 at the Conferenoe of London (§ 145).

(s) Rumania maintains also that the speinl situation of the European Commission on the river is prejudicial to her national defence. 
Her appetite being whetted by this success, she now endearoured to secure her own supremacy over the section of the river between the Iron Gates and Galatz, i.e., from the point where she ceases to be a riparian to the point where begins the authority of the European Commission, now "independent of the territorial authority."

Art. 55 of the Treaty provided for the making of regulations with respect to that intermediate section, but said nothing of the authority which would be entrusted with the supervision and execution of its provisions.

Was the territorial sovereign authority going to be disregarded? Rumania had all the more grounds for fearing it, because it was an excellent opportunity for Austria-Hungary to extend her supremacy beyond the Iron Gates. AustriaHungary did not neglect it.

\section{THREe PROJECTS.}

In virtue of Art. 55, the European Commission, at the sitting of December 18th, 1879, chose from among its members the German, Austrian and Italian delegates-a noteworthy choiceto prepare an "Avant-projet," which was presented in June, 1880. It has been termed: the Austrian project.

To it was opposed a project of French inspiration, called: Projet Barrère, from the name of the French delegate who presented it. Finally, the party chiefly interested, Rumania, ventured to present a counter-proposition.

Let us compare their solutions, as regards the chief question of who shall be entrusted with the execution of the regulations.

166. A.-The Austrian project.

The Austrian project recommended the creation of a new Commission: the "Commission mixte" of the Lower Danube, composed of delegates from the riparian States-Rumania, Bulgaria and Serbia-and from Austria-Hungary, a nonriparian Power of the Lower Danube, occupying by right the presidential chair, and having, for the decisions to be taken by the majority, the casting vote in case of equal division.

Tho Commission was conceived of as a deliberating and 
executive body. It was suggested that, as a check to, and regulator of, its executive power, it would ba well to allow apreal from its decisions to the European Commission; but Austria suscesded in obcaining the rajection of such a provision which incerfered with her plans.

167. B.-The "Projet Bakríke."

The "Projet Barrère," while presorving the idea of a "Commission rixte" proposes an alteration in its composition. In addition to the Rumanian, Bulgarian, Serbian delegates and the Austrian President, it is to comprise one of the menivers of the European Commission, appointed in turn for six roonths, according to the alphabetical order of the countries represented. His presence is meant to obviate the objection to the preponderating influence of Austria-Hungary.

\section{C.-The Rumanian counter-proposition.}

The Rumanian counter-proposition assigns the supervision of the execution of the regulations to a "Supervising Commission" (Comnission de surveillance) composed, bosides the delegates of the thros riparian States (Rumania, Sorbia, Bulgaria), of two delegates of the Europian Commission, designated in turn, for six months, according to the alphabetical order of the countries represented. The president is to bo chosen from these two delegates, by a majority of votes.

Rumania having one delegate as riparian, the Rumanian delegate to the Europan Commission rust never bo chosen.

In this proposition, the privileged position of AustriaHungary has entirely disappeared.

\section{The “Projet Barrére" Prevalls-Rumania's adie- SION REFUSED.}

We do not discuss the merits of the respective projects. The prinaiple of the "Commission rixte" triumphed in the form of the "Projet Barrère," slightly modified, but not enough to satisfy Rumania. She refused to give her adhesion, declaring that she could not "enter into 'combinations the effect of which 
would be to reserve the navigation from the Iron Gates to Galatz to the preponderating action of a single Power" $(t)$.

The question was again taken up at the Conference of London, 1883 ( $\$ 173$ ), but in spite of the adhesion of all tho great Powers, Rumania persisted in refusing to recognise the "Commission mixte.".

It cannot be denied that, as it was conceived, the "Commission mixte" needlessly encroached upon the sovereign rights of the riparian States of the Lower Danube. Why was a new spiccial régime necessary on that section of the river? Had the need for it ever bzen felt?

\section{InCREASing COMPLexity DUE to POLitical influence.}

More and more, remarks M. Louis Renault ( $\iota)$, the law regulating the navigation of the Danube becomes complicated. He adds: "Texts have succeeded on 3 another without being always clear, from the Treaty of Paris in 1856 to the Convention of London in 1883. They reflect the contest between the truly international spirit which has inspired the principle of freo navigation broadly set forth in the Treaty of Paris, and the particularistic spirit which inspires such and such riparians, especially Austria-Hungary; even over the part of the river of which she is not a riparian, she wants to dominate, and sho does not always meet with the necessary resistance. As a result, a situation needlessly complicated, and conflicting with Art. 15 of the Treaty of Paris, has been reached."

\section{The Treaty of London, 1883.}

171. Objects of the Conference of London.

The Conference of London, held in February and March, 1883 (Brit. and For. St. Pap., LXXIV., pp. 20 and 1231), had to deal with the prolongation of the powers of the European Commission, with the extension of its powers to Ibraïla, and with the regulation made in virtue of Art. 55 of the Treaty of

(t) Lo Danube. Aperçu hi-t. écon. et pəlit., by C. I. Baiçianu, with a preface by Ventila I. Bratiano (Paris, 1917). Ses Ch. VIII.

(ii) Preface to the book of MI. G. Demorgny on the Danube, by Mr. Louis Renault, de l'Institut de France. 
Berlin of 18r8. But other questions also forced themselves on the attention of the plenipotentiaries.

\section{A.-The Riparian States of the Lower Danube.}

There may first be mentioned: a request of Rumania to be "called upon to decide directly and equally with the other Powers on all the questions relative to the European Commis"sion" (Dispatch of the delegate of Rumania, 1st February, 1883. annex A. to Prot. 2 of February 10th, 1883); and a request of Serbia to be admitted to the Conference (annex B. to Prot. 2).

The Conference decided that they would "invite Rumania and Serbia in order to consult and hear them " but not, as the representative of Germany, Count Münster, put it, "en maîtresses de maison." It was also decided that Bulgaria might submit observations to the Conference through the Ambassador of Turkey.

At the sitting of the 13th (Prot. 3), the acceptance of Serbia was notified; but the Rumanian delegate, while declining the honour of attending the conferences, made the most solemn reservations to, and protests against, decisions which, taken without Rumania's participation, will not be, he declared, binding upon her (annex A. to Prot. 3). As to Bulgaria, she requested that she might present her observations herself (annex B. to Prot. 3).

The Conference decided to explain to the King of Rumania that their decision was based on their considering the present Conference as the continuation of the Congress of Berlin (1878) in which Rumania did not take part as a signatory. They expressed the hope that this communication would lead Rumania to modify her attitude. As to Bulgaria, the Conference maintained their decision.

\section{B.-The Regulation for the Section Between the Irox Gates and Galatz.}

"In order to exhaust all the means of conciliation" with regard to Rumania, Count Karolyi announced that his Government (Austria-Hungary) would be disposed to make some con- 
cessions, notably by renouncing the double vote, "under the condition that a definitive agreement should result from it" concerning the regulation.

The regulation was adopted definitively as it is annexed to Prot. 24 of the Commission of the Danube, June 2nd, 1882: the Powers formulating the wish (vœu) "that the States which do not take part in the deliberations of the Conference should give their adhesion to this unanimous vote, and should also adopt the regulation in question" (Collective Deelar. of the Confer., annexed to Prot. 3).

But Rumania, as we have seen, did not yield. Her principal objections were levelled at Austria's preponderance and the executive eharacter of the "Commission mixte." As an allusion was made to it at the Conference, Austria endeavoured to demonstrate that this executive character did not "in any way" infringe the sovereignty of the interested States: which sovereignty, it was said, remains unimpaired, apart from the application of certain river regulations explicitly indicated in the Treaties" (Prot. 2) (\$19).

\section{C.-Russia and the brinch of Killa.}

The question of the prolongation of the powers of the European Commission led to the examination of the principle of the permanence of that Commission. This prineiple was favourably looked upon, and the work of the Commission appreciated and praised, when Russia, in the name of "the sacred principle of sovereignty" presented a proposition with the object of securing the effective control over the branch of Kilia. Russia, it was explained, meant to resume all her authority over that part of the river (Prot. 4 ).

The Conference eould but sanction this determination, while taking all possible precautions in order not to compromise the work accomplished by the European Commission in the branches of Sulina and St. George.

As to the principle of free navigation, it was not questioned, for Russia had proclaimed that "it could no longer be in ques- 
tion, neither to-day nor ever; neither here, nor anywhere elso" $"(x)$.

\section{D.-The Powers of the European Commission.}

The powers of the European Commission, now extended to Ibraïla (inclusively), were prolonged for a period of twentyone years from April 24th, 1883. After that, it was decided that they might be renewed every three years by " reconduction tacite" (Prot. 6, March 1st, 1883) (y).

\section{E.-The duration of the "Commission mixte."}

It was proposed to fix upon the same duration for the "Commission mixte," but after certain observations presented by Russia, the Conference "decided to pass to the next question" (Prot. 8, March 10th) (z).

(x) For the details and the bearing of the Concessions to Russia, see Art. 3 to 6 of the Treaty of 1883 . Annex IV.

(y) It will be recollected that the Treaty of Paris, 1856 (Art. 18), contemplated a duration of about two years for the European Commission, i.e., the time necessary for the fulfilment of its task.

The Conference of Paris, August 19th, 1858 (Prot. 19), declared that "this period should be prolonged until the said works were completely finished."

Eight years later the work was not yet finished, and the Conference of Paris decided on April 24th, 1866 (Prot. 6), at the request of certain Powers, to fix a time for the definitive eompletion of it. A period of five years was agreed upon. After which, the Treaty of London of March 13th, 1871, prolonged the duration of the Commission by twelve years, i.e., the time necessary to redeem a loan effected in its name. This takes us to the date above mentioned.

(z) To our list of decisions, we may add that of inserting in Prot. 7, March 7th, "as having the same force (efficacité) as the other elauses of the Treaty," the following clause: "It is understood that the Agents of the European Commission will be able, for the sake of information, to move about on the branch of Kilia and its mouth."

It was also declared that the provisions of the regulation of Galatz "shall not be interpretel so as to restrict, as against the local authority, the jurisdiction of the Consuls over the vessels of their own country-a right which results from the treaties signed between the riparian States and the Powers. Finally, a request of Serbia to be admitted to the Commission on the same footing as Rumania in the European Commission was rejected (Prot. 4, February 20th). 
177. A possible explanation of the compromising attitude of NON-RIParian Powers.

A passage from the instructions of the Italian Minister for Foreign Affairs to the Italian Ambassador in London (Rome, January 10th, 1883) explains, perhaps, the attitude of the non-riparian Powers of the Danube towards the Austrian pretensions and the Russian request. They had above all to safeguard the existence of the European Commission. Speaking of the prolongation of the powers of this Commission, the Minister says: "It is the principal point submitted to the Conference of London. Its discussion has not only been foreseen, but imposed by Art. 54 of the Treaty of Berlin. The solution, in the affirmative, is for us, as for the other nonriparian Powers, very important; for the establishment and maintenance of the European Commission of the Danube is our only means of having, effectively and always, a vote in the affair; concerning the international navigation of the Lower Danube."

178. The Regulation of the Navigation Between the Iron Gates and Ibraila annexed to the Treaty of LoNDoN, 1883.

This regulation was not accepted by Rumania owing to the decision that the "Commission mixte" was charged with supervising its execution (Arts. 96-108 of the regulation) (see $§ \$ 164$ to 169 and 173).

Only a few general provisions need be mentioned. The navigation is entirely free. Merchant vessels of all nations may, on a footing of perfect equality, carry goods or passengers or may tow other vessels (Art. 1). No tolls based exclusively on the fact of navigation shall be levied, nor any duty on merchandise, as long as it remains on board (Art. 2). Customsduties can only be collected with respect to merchandise unloaded on the banks (Art. 6).

"The customs boundaries," explains the same article, "shall everywhere follow the banks of the river, without ever crossing them. It results therefrom, that vessels, 
transports, rafts, \&c., as long as they navigate or anchor on the river, without making any commercial transaetion with the banks, are entirely outside the sphere of action of the customs."

Transit is absolutely free for all merchandise of any nationality whatever, and of whatever origin or destination (Art. 7 ). As a general rule, no sanitary visits are imposed on vessels, as long as no epidemies have boen observed. The measures relative to quarantine are caleulated to reeoneile sanitary requirements with the needs of fluvial and maritime commeree (Art. 10).

\section{The RESUlts.}

The net results of the diplomatic transaetions which we have reviewed are:

(1) The eonfirmation of the liberal interpretation of Art. 109 of the Congress of Vienna.

(2) The establishment on the Danube of a plurality of régimes instead of the unity aimed at by the Congress of Vienna $(a)$.

11) As an illustration of this plurality, we note:-

1) Régime of Kilia ( $\$ 17.4$ ), whieh itself comprises the Russian régime of Dezakow, at the mouth, and the Russo-Rumanian régine of the braneh from Vicow to Toulteha.

(2) Régime of the European Commission (ep. $\$ 146$ ).

(3) Régime of the "Commission mixte" from the Iron Gates to Ibrailit (cp. § 173).

(4) Régime of the Rumanian "Thalweg" from the Iron Gates to Bahna; and of the Serbian thalweg (cp. Traité de Navigation entre l'AutricheHongrie et la Serbie, signed at Belgrade the 10/22 febr. 1882. Sturdza, p. $843, s q$., see $\Lambda_{\text {pp. }}$ I. $\left.\$ 318\right)$.

(5) Régime of the Iron Gates. (Cp. 5 Réglem. du ministère royal hougrois du Comuncree relatifs à la navigation et au prélèvement de taxes dans la partie du Danube entre Moldava et Turn-Severin, publiés le 14 juillet 1899. Sturdza, 509-531.)

(6) Austro-Hungarian régime. (Cp. "Instructions du Ministère hongrois des Communieations concernant l'exercice du droit de Navigation du 21 avril 1869," and "Iustruetion provisoire du ministère dn Commerce autrichien, relative à la navigation et à la police fluviale pour les parties du Danube de la Hante et de la Basse-Autriehe, du 31 aon̂t 187t." In German, in 
(3) Disregard of the sovereign rights of the riparian States of the Lower Danube (b) (cp. $\$ 22)$.

(4) The maintenance and confirmation of an institution, altogether exceptional and at first only provisional: viz., the European Commission. The exceptionally good work which it has accomplished has been its justification.

Political competitions have warped the first principles. But, on the whole, it cannot be questioned that the work of 1856 has contributed to favour the "general interest," though not perhaps in the best way, nor in the fairest, for certain riparians.

\section{The third STAGE.}

At any rate, our attention is now called in another direation from the protocols and regulations amongst which we have necessarily wandered, for what can be the use of collecting provisions of treaties, if we do not grasp the manner in which they are or may be executed? In 1884 arises the question of applying the principles of Vienna to the rivers of Africa. Fourteen Powers, including the United States of America, send delegates to Berlin for that and other purposes. All the leading principles, with which we have dealt, are once more examined. and discussed by specialists and by statesmen, the whole work of a century is by them, so to say, remodelled and brought up to date, so as to express more faithfully the ideas of their time.

\section{The Conference of Berlin (1884-1885).}

\section{Origins.}

France and Portugal being suspected of intending conquests and annexations on the banks of the Congo, publicists advocated the neutralisation of the Congo, lest this natural high road for

Sturdza: Documents relatifs à la liberté de la Navigation du Damme, Berlin, 1904, pp. 621-686.)

(7) German régime (Bavaria and Würtemberg). (Cp. "Convention de navigation entre l'Autriche et la Bavière du 12 Xbre 1851," and "Protocole du 5 juin 1855 par lequel le Würtemberg adhère à la Convention de navigation du 2 déc. 1851 entre l'Autriche et la Bavière." In German, in Sturdza, 1. e., pp. 609-620.)

(b) This furnishes the rather rare example of a justifiable protest in the name of violated rights of sovereignty. 
civilisation should become the scene of European squabbles and rivalries (de Laveleye, R. D. I., XV., p. 254 sq.).

Sir Travers Twiss (R. D. I., XV., p. 437, continued p. 547 and XVI., p. 237) opposed to neutralisation, which by the exclusion of war vessels might revive the slave trade, the idea of internationalising the Congo, in a way similar to the Danube.

The "Institut de Droit International" then meating at Munich, having examined a memoir by M. Moynier, expressed the wish to see the principle of free navigation for all flags applied to the Congo and its tributaries, and measures agreed upon with a view to preventing conflicts between civilised nations in Equatorial Africa.

In 1884, November 15th, the plenipotentiaries of Germany, Austria-Hungary, Belgium, Denmark, Spain, the United States of America (c), France, Great Britain, Italy, the Netherlands, Portugal, Russia, Sweden and Norway, and Turkey, assembled in Berlin to discuss the following points:

(a) Freedom of commerce in the basin and mouths of the Congo.

(c) 1t is interesting to note why the United States of Ameriea took part in the Conference.

The reason allezed for inviting the United States is that Liberia is under their protestion. (Letter from the U.S. Legation at Berin to the Secretary of State, Otuber 13th, 1881.)

The Secretary of State hesitates. Would not acceptance be contrary to the policy of "non-interference"?

Mr. Kasson replies: "So far, the scope of the Conference offers nothing embarrassing; and only presents points of business intercourse, in which we as a commereial power are equally interested with the others. As we took part in the Conference; respocting the 'Scheldt dues' ( $\$ 9 t)$, respecting postal affairs, a eommon meridian, \&c., so should we naturally be represented in a Conference to recommend commereial regulations which will affect all countries in respest to a trado so important in the future as that with the Westem Coast and Rivers of Afrisa. It appanrs to be also the wisest means to prevent selfish arrangements by a single European Power with other single, and perhap irresponsible, authorities on the coa:t or rivers of Africa." (Ber.in, Ottaber 15th, 1884.)

On the 17th, the Secretary of Siate accepts the invitation under the condition that the business to be brourht before the Conference is to be limited to the three heads mentioned in the invitation, and pointing out that the Government of the Unitel States reserves the rig'at to desline to accept the conelusions of the Conference. (Letter to Baron von Alvensleben, Washington, October 17th, 1884.) 
(b) Free navigation for all flags on the Congo and Niger.

(c) Definition of the formalities necessary for effective new occupations.

182. Prince von Bismarch's speech. Freedom of comMERCE AND FREEDOM OF NAVIGATION.

Prince von Bismarck, chairman of the Conference, having observed (Prot. 1) (d) that the fundamental idea of the programme was to facilitate access to the interior of Africa to all commercial nations, subnritted a draft containing, among others, the following propositions:

I. As regards freedom of commerce in general.

"Every Power that now exercises, or shall hereafter exercise, sovereign rights in that region, is to allow free access thereto to the flags of all nations without distinction. Suck Powers are not to grant any monopolies or to introduce any discriminating treatment. All taxes are to be prohibited save those to be levied by way of reimbursement for expenses incurred in the interest of commerce."

II. As regards freedom of navigation in particular.

"The Congress of Vienna, by proclaiming freedom of navigation on the rivers which flow through the territories of several States, sought to prevent any monopoly of the advantages inherent in a watercourse. This principle has passed into International Law, both in Europe and America. Now, the German Government would gladly adhere to a proposition tending to regulate, outside the Conference, the question of free navigation on all the rivers of Africa....

"This draft has been modelled after Arts. 108 to 116 of the Final Act of the Congress of Vienna, 1815; Arts. 15, 16 and 19 of the Treaty of Paris, 1856; the Act of Navigation of the Danube of $185 \%$, the Act relative to the navigation of the mouths of the Danube adopted in 1865, and after the identical treaties concluded in 1853 between

(d) Protocols of the General Act of the West African Conference. Blue Book, C. 4361 . 
France, Great. Britain and the United States of America on the one hand, and the Argentine Confederation on the other, in order to secure the free navigation of the Parana and the Uruguay.'

"The fundamental principle of this draft is to secure full and entire freedom of navigation to all flags, and exemption from all taxes save those levied in order to pay the expenses of works rendered necessary by the requirements of narigation."

18:3. Great Britain's Reservations With REgard to the Niger.

Sir Ed. Malet, referring to the second basis of the discussion (free navigation for all flags on Congo and Niger), said that "H.M.'s Government would be glad to see the principles adopted by the Congress of Vienna extended, not only to the Congo and the Niger, but also to other African rivers. The question for practical consideration will be, in the opinion of H.M.'s Government, not so much the acceptance of the general principles as the mode of their application." . . . . "H.M.'s Government have become convinced, that the navigation of the Congo might be regulated by an International Commission, the creation of which they have repeatedly urged. . . ." "The situation of the Niger is entirely different. The establishment of a Commission on that river is regarded by us as impracticable." The river is insufficiently explored. The upper river has no communication with the lower. The river near the sea is divided into a network of mouths. The comnerce of the interior is, for the most part, in the hands of the coast tribes who act as middlemen, and who, having a keen regard for their own interests, are hard to manage and control. Commerce has been indebted for its derelopment almost exelusively to British enterprise. "It is now entirely in British hands, and the most influential tribes, after having for many years considered the agents of that comtry as their protectors and counsellors, have now, in compliance with their urgent and repeated requests, been officially placed under the protectorate of Great Britain. This condition of thing involves, in an imperative manner, a differ- 
ence in the application of the principles of the Vienna Congress. The coast line and the lower course of the river are sufficiently under control to enable the Government of Her Britannio Majesty to regulate its navigation while adhering to the principle of free navigation by a formal declaration" $(e)$.

\section{The Procedure adopted by the Conference.}

The Conference passed to the question of free navigation at the fourth sitting. Owing to the technical character of the Germar $_{1}$ draft $(f)$, it was proposed to refer it to a committee charged with examining it in detail and presenting to the Conference a report proper to guide its decisions (Prot. 4, Dec. 1st, 1884).

Sir Ed. Malet, referring to the reasons above summarised ( $\$ 183$ ), then asked that the questions respecting the Congo and the Niger should be discussed separately. But Baron det Courcel observed that he thought that, in principle, the Conference would prefer to see a uniform régime applied to the two waterways. "If certain scruples connected with considerations of sovereignty are allowed to intervene with respect to the Niger, might not the same considerations be pleaded with respect to the Congo? Baron de Courcel then concluded that the régimo applicable to the Congo should not be definitely adopted until the régime of the Niger was determined, as the two sets of rules ought to be as similar as possible. With this reservation, he adhered to Sir Ed. Malet's request.

\section{The composition of the committee and its Mission.}

The composition of the committee was then discussed. It was proposed to form a limited committee comprising in principle the representatives of the most interested Powers included

(e) See also Memorial relative to the Niger, presented by His Excellency the plenipotentiary of Great Britain, annexed to Prot. 1. \& Project of Declaration by Great Britain to secure liberty of navigation on the Niger, annexed to Prot. 4. A British project of the Navigation Act of the Niger (ibid.).

(f) The result of the blending of a first German "projet" with a French "avant-projet." 
in tho first series of invitations sent out for the Conference; while the plenipotentiaries of the Powers comprehended in tho second series of invitations should have the right to attend, whenever they thought proper, on the same footing as the other members and with a deliberative voice.

Besides, the committee would bo empowered to claim the eoneurrenee of the delegates of the Powers, and to hear all. persons whom it might judge useful to consult.

As to its mission, the committee would have to eonsider first the régime of the Congo and then that of the Niger; the devisions eoncerning the former baing but provisional, pending the resolutions pertaining to the latter (Prot. 4).

\section{A sub-Committee.}

Again, owing to the technical and delieate nature of the subjeet, the eommittee deenıd it advisable to submit the two drafts $(g)$ to a remodelling proces by a sub-eommittce eonsisting of M. de: Kusserow, on s of the German plenipotentiaries, Baron Lambermont, one of the Bəlgian plenipotentiaries, M. Engelhardt, delegate of Franse, M. Crowe, English dəlegate, and M. Cordeiro, delegate of Portugal, to whom were added M. Banning, Belgian delegate, and Sir Travers Twiss, the English jurist.

This sub-committes, after eareful and dotailed exanination, introduced certain modifieations of matter and form, and tho committee, in its turn, after long deliburations, adopted two texts which were submitted to tho Conforence with a remarkable report by Baron Lambermont, on the work of tho commitiee (annex to Prot. 5).

\section{The PLAN FOLLOWED.}

It would ba unnecessarily long to reproduce the drafts of the sub-committee and of the eorimittre. As wo are partieularly eoneerned with what the delegates of the Powers have

(g) One dafi of an Ast of Navization for the Conzo and the Niger prepared by the German penipotentiaries; and ons draft of an Aet of Navigaiion for the Niger by the British Ambassador. 
accepted as applicable, we shall rather start from the text finally adopted. But from the report on the work of the committee, the protozols of the discussions of the Conference, and the comparison of the various projects with the text of the Final Act, we shall make a comnrontary on the articles, which by pointing out what principles were unanimously adopted, what were diseussed and on what grounds aceepted or rejected, will help us to form a notion of the progress of the principles which may be said to form the conventional law of nations on the question of international rivers.

\title{
Act of Navigation for the Congo.
}

\author{
Art. 13 (I.) (h).
}

188. The Congo and its branches open to the merchant VESSELS OF ALL NATIONS.

"The navigation of the Congo, without excepting any of its branshes or outlets, is, and shall remain, entirely free for the merchant ships of all nations, whether carrying. cargo or ballast, for the transport of goods or passengers. It shall be regulated by the provisions of this Act of Navigation, and by the rules to be made in pursuances thereof."

189. Equality of treatment for all flags; coastino

TRADE; BOAT TRAFFIC.

"In the exercise of this navigation, the subjects and flags of all nations shall in all respests be treatod on a focting of perfect equality, not only for the direct navigation from the open sea to the inland ports of the Congo, and vice vers $\hat{a}$, but also for the great and small coasting trade, and for boat traffic (batellerie) on the course of the river."

190. No privileges: RIPARIAN aNd NON-RIPARIAN States; companies, corporations AND PRIVATE PERSONS. "Consequently, on all the course and mouths of tho Congo, no distinction shall be made between the subjects

(h) Art. 13 in the Act of Navigation; (1) in the Draft of the Committee. 
of riparian States and those of non-riparian States, and no exclusive privilege of navigation shall be conceded to companies, corporations, or private persons whatsoever."

\section{International Law.}

"These provisions are recognised by the Signatory Powers as being henceforth part and parcel of International Law."

\section{Free cavigation for all.}

The connection which exists betwoen this article and Art. 2 of the Declaration relative to freedom of commerce deserves notice. It has already appeared in the propositions of Prince ron Bismarck's draft which we have quoted $\$ 182$. It puts our question in its true place $(i)$ (cp. $\$ 330$ ).

The absolute equality among the subjects and ressels of all nations is emphatically and repeatedly proclaimed. As Baron Lambermont $(k)$ remarks: "One of the consequences of this, which is all the more worthy of attention from the fact of its having been more frequently contested, is the abolition of all distinctions between the subjects of the riparian and those of the non-riparian States" (\$190).

(i) We read in the Report of the Committee on the draft Declaration concerning freedom of commerce (Annex II., Prot. 4), under Art. 2: "The principle of free navigation forms essentially a part of commercial freedom. Art. 2 will find its complement in the Act of Navigation. . . . Viewed in its entirety, the economic work of the Conference will really appear in the solutions harmonised with one another, which shall so tahe their place in the Declaration and in the Act of Narigation" (cp. $\$ 50$ ).

(k) Lest it should be thought that we take too great account of his report, we may point out: (a) that it is the official and only source of our knowledge of the proceedings of the Committee; (b) that we read in Prot. 5: "This remarkable work renders account in the elearest manner of the preparatory labours of the Committee. If it should not be considered as a legal commentary upon the acts of the Conference, since the latter alone has the right to determine upon the decisions, and to give them, in their protocols, authentic explanation, it will none the less be a valuable guide for those who will have hereafter to study or to apply the texts prepared by the Commission." The president then added that the report should be annexed to the 5th protocol. 
ART. 14 (II.).

193. No RESTRICTIONS OR CHARGES TO BE IMPOSED.

"The navigation of the Congo shall not be subject to any restriction or impost (redevance) which is not expressly stipulated for by the present Act."

194. Forbidden dues.

"It shall not be subject to any port dues, staple or storehouse duties, or to compulsory breaking bulk, or entry into port (aucune obligation d'échelle, d'étape, de dépôt, de rompre-charge ou de relâche forcée)."

195. No transit DuEs.

"Throughout the whole extent of the Congo, the ships and goods in process of transit on the river shall not be submitted to any transit dues, whatever their starting place or destination."

196. No TOLLS TO BE LEVIED.

"There shall be levied no maritime or river toll based on the mere fact of navigation, nor any tax on gcods aboard of ships."

197. Character of dues that may be levied.

"There shall only bo levied taxos or duties having the character of an equivalent for services rendered to navigation itself, to wit:"

198. Dues for the use of wharves, etc. . .

"I. Harbour dues for the actual use of certain local establishments, such as wharves, warchouses, \&c.

"The tariff of such dues shall be franed according to the cost of constructing and maintaining the sail local establishments; and it shall be applied without regard to the place whence the vessels or their cargo may come."

K. 
199. Pilot dues.

"II. Pilot dues for the sections of the river where it may be necessary to establish stations of qualified pilots.

"The tariff of these dues shall be fixed and calculated in proportion to the services rendered."

200. Lighthouse AND OTHER SUCH DUES.

"III. Charges raised to cover technical and administrative expenses incurred in the general interest of navigation, including lighthouse, bəa:on and buoy dues.

"The last mentioned duas shall bo based on the tonnage of vessels as shown by the ship's papers, and in accordanco with the rules adopted on the Lower Danube."

201. No differential dues to Be Levied.

"The tariffs by which the various dues and taxes enumerated in the thres preaeding $§ \S$ shall be levicd, shall not involve any differential treatment, and shall be officially published at each port."

202. Periodical revision.

"Tle Powers reserve to themselves the right to consider, after the lapse of five years $(l)$, whother it may be neessary to revise, by common consent, the above mentioned tariffs."

203. The PRINCIPLe.

Art. 14 dealing with dues on navigation, starts from tho principle-which Baron Lambermont declares "one of the latest and most important advances that commercial law has made "that any maritime or fluvial toll based upon the nose fact of navigation is to be prohibited $(m)$.

(l) See Tariff, 22nd De'ember, 1890, Map of Africn. I., 90.

$(m)$ Cp. Grotius' prin'ip'e, $\S 13$, and Lord C'ancariy's proposed amendment at Vienna, $1815, \S 56$, note. 
204. Mode of collection.

It is provided that the "charges raised to cover technical and administrative expenses incurred in the general interest of navigation" shall be based "on the tonnage of vessels shown by the ship's papers, and in accordance with the rules adopted on the Lower Danube." Baron Lambermont reports: "On the Danube, the dues of this class are collected simultanerously. Should this be the case on the Congo? The representative of Belgium thought it should, but the Frensh ambassador thought that this clause might give rise to difficulties in its application. It was understood that the International Commission would decide this point in its regulations, taking the circumstances into account."

\section{Dues on native vessels.}

The minister of the United States having asked whether narigation dues would be collected from vessels or boats belonging to independent native tribes, Baron Lambermont observed that "the rights of native peoples or States should bo respected in this matter as in all others. But, outside the limits of their territory, native boatmen, like all others, are subject to the laws of the country where they are navigating. The time will come when they, like everybody else, will be benefited by the improvements introduced; it is therefore proper that they should be subject to the same obligations, and they would have no ground for complaint, unless the usage accorded to other nations should not be accorded to them." Besides, the prudence of the International Commission as well as the territorial authorities will prevent conflicts. "On the Danube, continued Baron Lambermont, vessels of less than 100 tons burden are exenupt from navigation dues, and it is a well-known fact that African vessels scarcely ever carry more than one or two tons."

206. Periodical revision.

The last section, reserving the privilege of revising the tariffs after five years, was suggested by the ambassador of Italy. "Such a provision," it is said in the report, "exists on the 
Danube, and since 1865, three successive revisions have rendered a material reduction of the navigation dues prossible" (cp. $\$ 142)$.

\section{ArT. 15 (III.).}

207. Affluents of the Congo.

"The affluents of the Congo shall in all respects be subject to the same rules as the river of which they are tributaries."

208. Streams, Lakes and canals.

"And the same rules shall apply to the streams and rivers as well as to the lakes and canals in the territories defined in $\S \S 2$ and 3 of Art. 1 .

"However, the powers of the International Commission of the Congo shall not extend to the said rivers, streams, lakes and canals, except with the assent of the States under whose sovereignty they are placed. It is well understood, also, that with regard to the territories mentioned in $\S 3$ of Art. 1, the consent of the Sovereign States on which thesc territories depend is reserved."

\section{Conventional zone.}

We have pointed out the connection existing between freedom of commerce and freedom of navigation ( $\$ 192)$. By Art. 3, free navigation is to apply to the same zone as comnorcial freedom-but with the same reservations as to the territories belonging to independent States, as was requested by the plenipotentiaries of Portugal and Turkey (cp. $\$ 330$ ).

At the fifth sitting of the Conference, Baron de Courael stated that the régime applicable to "rivers and streams included in the region of commercial liberty although having. their course outside the natural basin of the Congo, is only the normal régime of free navigation stipulated for in favour of merchant vessels. The assimilation of these rivers and streams to the Congo itself and to its affluents does not extend to the clauses of the present Act, which are based on another order of 
ideas; it does not extend, e.g., to the clause which introduces on the Congo a new and special régime in time of war. At least, the French Government, as far, as it is concerned, thinks that these rivers and streams should be maintained under the authorit $\dot{y}$ of the ordinary rules of the law of nations, excepting, be it understood, the possibility of subsequent agreements which might be established in an order of ideas analogous to that which animates the recent proposition of the minister of the United States" ( $\$ 260)$.

In the draft of the sub-committee and the committee, Art. 3 included only the first two sections; to which a third section was added, embodying the reservations above spoken of.

Art. 16 (IV.).

210. Roads, Railways or lateral, canals open to all NATIONS.

"The roads, railways, or lateral canals which may be constructed with the special object of obviating the unnavigability or correcting the imperfection of the river route in certain sections of the course of the Congo, its afluents, and other waterways assimilated to them by Art. 15, shall be considered in their quality of means of communication as dependencies of this river, and as equally open to the traffic of all nations."

211. Tolls.

"As on the river itself, there shall be collected on these roads, railways and canals, only tolls calculated on the cost of construction, maintenance, and management, and on the profits due to the promoters (entrepreneurs).

"As regards the tariff of these tolls, foreigners and the natives of the respective territories shall be treated on a footing of prerfect equality."

212. RAISON D'ÊTRE OF ART. 16.

"This article," observes Baron Lambermont in his report, "owes its existence to the physical conformation of the African continent, almost the whole central portion of which forms an 
elevated tableland descending more or less abruptly to the sea. Nearly sixty leagues of falls and rapids separate the middle course of the Congo from the vast estuary which forms its lower section. This circumstance explains the fact that, during the four centuries that it has been known, this great artery has remained, throughout the greater part of its course, almost barreri in respect to the commerce of the world and the civilisation of Africa."

\section{An innovation.}

Art. 4 introduces a new idea into International Law, which will certainly be regarded as a step in advance. It considers as a dependency of the river the railway and the road or anal that may hereafter be substituted for the obstructed portion of its course, and extends the same international protection over this supplementary way. to not a single objection.'

\section{Mr. Sandford's proposition.}

But the report goes on to ask: "Is it sufficient? Would the object of the Conference be really attained if the instrument relative to the navigation of the river did not provide for the construction of a road or railway that would speedily secure unbroken communication, and if it were not calculated to hasten such construction?"

In consequence, one of the plenipotentiaries of U. S. A., Mr. Sandford, submitted to the Conference a proposition according to which a road was to be built in the region of the cataracts, the construction of which was to be entrusted to the most deeply interested riparian State, and the necessary: right of way was to be established. Divergences of opinion prevented the sub-committee from arriving at any decision. According to the Portuguese plenipotentiary, the question was not ripe, the ground insufficiently known. "At all events, it would be necessary to consider the rights of the riparian States." While the French ambassador considered the question as unripe, the British ambassador adhered to Mr. Sandford's proposition, as did also the plenipotentiaries of Germany, who, 
however, thought that " a wording should be adopted that would be acceptable to all the parties interested, the starting point of which should be that everybody considers the speadiest junction possible of the Upper and Lower Congo as an indispensable work."

One of the Belgian plenipotentiaries then dwelt on the importance of connecting the two navigable sections of the Congo. The execution of this project should be confided to a riparian Power. Thus in 1878, the Treaty of Berlin entrusted Austria with the execution of the works necessary at the Iron Gates ( $\$ 159$ and 161). The debate was not concluded.

\section{ART. 17 (V.).}

215. International Commission.

"There is instituted an International Commission, charged with the execution of the provisions of the present Act of Navigation."

216. Fach Power to be represented by one delegate with ONE VOTE ONLY.

"The signatory Powers of this Act, as well as those who may subsequently adhere to it, may always be represented on the said Commission, each by one delegate. But no delegate shall have more than one vote at his disposal, even in the case of his representing several Governments."

217. Payment of Delegates, agents and employees.

"This delegate shall be directly paid by his Government. As for the various agents and employés of the International Commission, their remuneration shall be deducted from the amount of the dues collected in conformity with $\S \S 2$ and 3 of Art. 14 .

"The particulars of the said remuneration, as well as the number, grade, and powers of the agents and employés, shall be entered in the returns to be sent yearly to the Governments represented on the International Commission." 


\section{The Danubian precedent.}

The idea of this article was suggested by the services rendered by the European Commission established in 1856 for the improvement of the navigation of the mouths of the Danube. The committee adopted the idea without discussion; though debates arose concerning the proper task, and the nature and limits of the powers, of the International Commission.

\section{Art. 18 (VI.).}

219. INVIOLABILITY OF MEMBERS AND AGENTS, THEIR OFFICES AND ARCHIVES.

"The members of the International Commission, as well as the agents appointed by it, are invested with the privilege of inviolability in the exercise of their functions. The same guarantee shall apply to the offices and archives of the Commission."

220. The Belgian delegate's original proposition.

This article is due to the Balgian delegate. His formula, in its first part, declared the International Commission independent of the territorial authority $(n)$, and in the second. granted the benefit of exterritoriality to the agents appointed by that Commission.

"The question was," it was observed, "not to confer any new powers on the Commission to be constituted, but rather to define its public eharacter, to fix the manner of its existence, and to secure to it the guarantees which are indispensable for the accomplishment of its task."

\section{French objections.}

But the delegate of France in the sub-committee expressed his opinion that "the European Danube Commission was an exception, that its type could not be generalised, and that the proposed regulation was rendered useless by Art. 8 in which

(n) Liko the European Commission of the Danube since the Treaty of Berlin, 1878. (See $\$ \S 155$ and 162.) 
the powers of the International Commission are expressly defined. He added that the régime applied to the Danube was of a spesial character, and that its extension to the Congo, where it was nocessary before everything to appeal to the initiative of the riparian States, could not bə justified."

\section{Reply of the Belgian delegate.}

The Belgian delegate, on the other hand, maintained that " a régime, that had bəen found admirable for the Danube, that had beer accepted as a blessing by all nations and that had been sanctioned by an uninterrupted seriss of European decisions ( $\$ 175$ and the note), must, $\grave{a}$ fortiori, be adapted to the Congo where there existed only an embryonic eivilisation. He urged that it was inadmissibe to permit that, for lack of independence, a Commission appointed by the maritime Powers of both worlds in the interest of civilisation, should be exposed to the danger of seeing its whole action paralysed by the opposition of a single one of the riparian States."

\section{Adhesion of Several members.}

Certain modifications were made, and several nrembers of the sub-committee then adhered to the proposition. But M. Cordeiro, the Portuguese delegate, made some explicit reservations relative to the independence of the riparian States.

224. Thy clause of exterritoriality. Suggestion of Sir Travers Twiss.

"In its original form," the report goes on, "Art. 6 granted the privilege of exterritoriality to the International Commission, its officers and establishments. This prerogative appeared too great, and a guarantee of personal inviolability was substituted for it at the suggestion of Sir Travers Twiss."

\section{Proposal to reserve the first clause.}

"The text adopted by the sub-committee having been again laid before the eommittee, the same debate was reopened, and in almost the same terms. On the proposition of Baron de Courcel, the committee then decided to reserve the first proposi- 
tion of Art. 6-whieh treats of the position of the International Commission as regards the territorial authorities-until a decision had been reached relative to Art. 8, which enumerates the powers of the same Commission."

\section{Adoption of the second clause.}

"This method was accepted, and the second part of Art. 6 which declares the members of the Commission inviolable, as also their officers, when engaged in the performance of their duties, and extends the same privilege to their offices and archives. was then adopted without debate."

\section{Reservation of Count Kapnist.}

Count Kapnist adhered to Art. 6, but made reservations relative to this and other articles, on the ground, as he explained at the fifth Conference, that they "would tend, if they were made general, to introduee very considerable innovations into International Law." Such rules ought, therefore, to be limited to those countries where the local circumstances and existing international interests justify them, but Russia could never consent to their creating a precedent or a rule of public law binding upon it, in any degree whatever, in othor circumstances and other loealities (ep. $\S \S 271$ and 273 ).

\section{Art. 19 (VII.).}

228. Constitution of the Commission.

"The International Commission for the navigation of the Congo shall be constituted as soon as five of the Signatory Powers of the present General Act shall have appointed their delegates.'

229. Nomination of Delegates to be notified to German Government.

"Pending the constitution of the Commission, the nomination of these delegates shall be notified to the Imperial Government of Germany, by whose care the 
necessary steps will be taken to summon the meeting of the Commission."

230. Navigation, police, pilotage and quarantine reguLATIONS.

"The Commission will at once draw up regulations concerning navigation, police, pilotage and quarantine. These regulations, as well as the tariffs to be framed by the Commission, shall, before coming into force, be submitted for approval to the Powers represented on the Commission. The Powers interested will have to communicate their views with as little delay as possible."

231. INFRINGEMENT OF RULES.

"Any infringement of these rules shall be checked by the agents of the International Commission wherever it exercises direct authority, and elsewhere by the riparian Power."

232. METhOD OF APPEAL.

"In the case of an abuse of power, or of an act of injustice, on the part of any agent or employee of the International Commission, the person who considers himself to be aggrieved in his person or rights may apply to the Consular Agent of his country. The latter shall examine his complaint, and if he finds it primâ facie reasonable, he will then be entitled to bring it before the Commission. At his instance, the Commission, represented by at least three of its members, shall, in conjunction with him, inquire into the conduct of its agent or employee. Should the Consular Agent look upon the decision of the Commission as raising questions of law ('objections de droit '), he will report on the subject to his Government, which may then have recourse to the Powers represented in the Commission, and invite them to agree as to the instructions to be given to the Commission." 


\section{Ayproval of the regulations.}

Paragraph 3 gave rise to a long discussion. Tho Dutoh and French plenipotentiaries insisted on reserving to their Governments the privilege of approving all the organic regulations and the tariffs; but the British plenipotentiary, fearing that this system would oceasion excessive delay, proposed that the Commission should vote by a majority of two-thirds and that the approval of the Governments should be presumed, unless they objected within six months. A German plenipotentiary even proposed a delay of one year, "sinee it seemed to him inadmissible that a single State should have the right of indefinitely paralysing the aetion of all the others." His proposition was rejeeted, and it was decided that "the Commission shall adopt the organic regulations and the tariffs by a mere majority; the Governments represented will have the right to approve them before they are put into operation, but they engage to make known their opinions as speedily as possible" (Lambermont's Report).

\section{Method of appeal.}

The last $\S$ creating a method of appeal ( $\$ 232$ ) was adopted on the suggestion of the British Ambassador.

\section{Art. 20 (VIII.).}

235. Powers of the International Commission.

"The International Commission of the Congo, charged according to Art. 17 with the execution of the present Act of Navigation, shall, in particular, have power:

236. WORKS NECESSARY to ENSURE the NAvigabILITy.

"I. To decide what works are necessary to ensure the navigability of the Congo in accordance with the needs of international trade.

"On the sections where no Power exercises sovercign rights, the International Commission shall itself take the necessary measures for ensuring the navigability of the river. 
"On the sections of the river held by a sovereign Power the International Commission shall concert its action (s'entendra) with the riparian authorities."

237. Pilotage tariff and navigation Dues.

"II. To fix the tariff of pilotage and the general tariff of navigation dues, as provided for by $\S \S 2$ and 3 of Art. 14.

"The tariffs mentioned in the first $\S$ of Art. 14 shall be framed by the territorial authorities within the limits prescribed in the said article.

"The levying of the various dues shall be carried out by the international or territorial authorities on whose behalf they are established."

238. Administration of Revenue.

"III. To administer the revenue arising from the application of the preceding paragraph."

239. Quarantine establishment.

"IV. To superintend the quarantine establishment created in virtue of Art. 24."

240. Appointment of officials and employees.

"V. To appoint officials for the general service of navigation, and also its own employees."

241. Sub-inspectors.

"It will be for the territorial authorities to appoint subinspectors on sections of the river occupied by a Power, and for the International Commission to do so on the other sections.

"The riparian Power shall notify to the International Commission the appointment of sub-inspectors, and shall undertake the payment of their salaries.

"In the exercise of its functions, as above defined and limited, the International Commission shall be independent of the territorial authority." 


\section{Few divergences of views.}

No great divergence of views appeared in the discussions. In No IV. (§ 239) "superintend" w'as substituted for "control" at the request of the British Ambassador, as implying a less extended intervention.

The last $\S$ reproduces, with certain modifieations of form, the first proposition referred to under Art. 6 (§ 219).

\section{ArT. 21 (IX.).}

243. Recourse to war vessels by the International Commission.

"In the accomplishment of its task, the International Commission may, if nesd bo, have recourse to the war vessels of the Signatory Powers of this Act, and of those who may in future asode to it, under resarve, however, of the instructions which may bo given to the commanders of these vessels by their respective Governments."

244. The Danubian precedent.

It is, in effect, a provision in force at the mouths of the Danube. On the Congo, the necessity of protecting merehants, factories, and vessels against pirates or in conflicts with the natives would alone have boen justification enough.

Whereas the Danube is not ascossible to war vessels, the Congo is; but they must observe the rules of neutrality in time of war (cp. $§ 154)$.

\section{ART. 22 (X.).}

245. Wai vessels so EMPloyed EXempt From Navigation DUES.

"The war vessels of the Signatory Powers of this Act, that maj enter the Congo, are exempt from payment of the navigation dues provided for in $§ 3$ of Art. 14."

246. Otherwise liable to PAyMent of PILOT AND IIARbour DUES.

"But unless their intervention has bren called for by the International Commission or its agents, in terms of 
the preceding article, they shall bo liable to the payment of the pilot or harbour dues which may eventually be established."

\section{ArT. 23 (XI.).}

247. LOANS FOR TECHNICAL AND ADMINISTRATIVE EXPENSES.

"With the view of providing for the technical and administrative expenses which it may incur, the International Commission created by Art. 17 may, in its own name, negotiate loans to ba exclusively guaranteed by the revenues raised by the said Commission.

"The decisions of the Commission dealing with the conclusion of a loan must bro come to by a majority of twothirds. It is un lerstood that the Governments represented on the Commission shall not in any case be held as assuming to guarantes, or contracting any engagement or joint liability (solidarité) with respest to the said loans, except under special Conventions concluded by them to this effect.

"The revenue yielded by the dues speoified in $\S 3$ of Art. 14 shall brar, as a first charge, the payment of the interest and sinking fund of the said loans, according to agreement with the lendərs."

\section{Responsibility of Governments?}

In the draft of the sub-eommittee, Art. 5 provided that the International Commission might contingently negotiate loans with the authorisation of the Governments represented in it.

The degree of responsibility of the Governments was discussed. The Belgian plenipotentiary having suggested that Governments which guaranteed a loan should be held liable "only in proportion to the share of their flag in the navigation of the river," the plenipotentiaries of the U. S. A. and of the Netherlands declined all financial guarantees. The Bcl rian plenipotentiary then explained that "Governments should in no case be held as debtors or guarantors except with their individual consent." The British Ambassador asked that the Commission be authorised "to contrast loans directly, by a 
majority of two-thirds, the minority being under no obligation."

249. The clause “ with the authorisation of the GovernMENTS THERE REPRESENTED" STRUCK OUT.

On re-examination, the clause "with the authorisation of the Governments there represented," again led to doubts: (a) Did an affirmative vote place a Government under a financial, or at least, a moral obligation? (b) In case of a negative vote, could the majority hold the minority responsible?

To prevent misapprehension, the striking out of the clause in question was proposed by the plenipotentiary of Spain, and supported by the plenipotentiaries of France, Belgium, the United States and Germany.

\section{The VIEW THAT PREVAILED.}

The British Ambassador observed that "resolutions so important as the conclusion of a loan should not be adopted by the International Commissioners without being furnished with special powers." But it was replied that, "if the Commission had a distinct personality, which would enable it to contract for and by itself without entailing responsibility upon anyone but itself, this would be to the intriast of the Governments which would thus avoid all responsibility, and would meet the exigencies of the situation, which might, for work of an urgent character, demand resources immediately available."

This opinion prevailed, and the text was amended accordingly and adopted at the fifth Conference, with another slight amendment by Baron Lambermont, substituting "as assuming no guarantec nor contracting any engagement or joint liability" for the former "as assuming no guarantre or joint liability" (cp. $§ \$ 144$ and 162).

\section{Discrimination Rejected.}

The committe rojected the notion of a discriminating tax to be imposed on the vessels of Powers not having guaranteed loans. 


\section{Art. 24 (XII.).}

252. Quarantine establishment at mouth of Congo.

"At the mouth of the Congo there shall be founded, either on the initiative of the riparian Powers, or by the intervention of the International Commission, a quarantine establishment for the control of vessels, passing out of, as well as into, the river."

253. Sanitary CONTRol over vessels.

"Later on the Power's will decide whether and on what conditions a sanitary control shall be exercised over vessels engaged in the navigation of the river itself."

\section{Art. 25 (XIII.).}

254. Freedon of navigation of Congo and territorial WATERS DURING WAR.

"The provisions of the present Act of Navigation shall remain in force in time of war. Consequently all nations, whether neutral or belligerent, shall always be free, for the purposes of trade, to navigate the Congo, its branches, aflluents, and mouths, as well as the territorial waters opposite the mouths of the river."

255. Roads, RaIlways, LaKes aNd CANALS INCLUded.

"Traffic shall similarly remain free, despite a state of war, on the roads, railways, lakes, and canals mentioned in Arts. 15 and 16."

25̃6. Transport of CONTRaband of War excepted.

"There shall be no exception to this principle, except in so far as concerns the transport of articles intended for a belligerent and regarded, according to the law of nations, as contraband of war."

257. Neutrality of works and establismients.

"All the works and establishments created in pursuance of the present Act, especially the collecting offices and 
their safes, as well as the permanent service staff of these establishments, shall enjoy the benefit of neutrality (placés sous le régime de la neutralité) and shall, therefore. be respected and protected by the belligerents."

255. Th:: овJест оF ARt. 25.

The object of this article is "to extend, as far as possible, to time of war the guarantees stipulated for in time of peace, and to secure. even during the prevalence of hostilities, freedom of commerce and navigation on the Congo, its affluents, and the ways of communication that are assimilated to them."

\section{A DRAFT COMPROMISE.}

Three wordings were proposed by the German, Belgian and British delegates. As they agreed in some fundamental points. they were consolidated in the following draft compromise: "The provisions of the present Act shall remain in force even during a state of war. Consequently, the navigation of all nations, whether belligerent or neutral, shall always be free for commercial purposes, on the Congo, its branches, affluents and mouths, as well as on the territorial waters opposite the mouths of this river.

"The traffic shall similarly remain free, despite a state of war, on the roads, railways, lakes and canals, mentioned in Arts. 3 and 4 .

"There shall be no exception to this principle, except as regards the transport of articles intended for a belligerent and regarded, according to the law of nations, as contraband of war.

"All the works and establishments created in pursuance of this Act, notably their collecting offices and their safes, as well as the staff permanently in the service of these establishments, shall enjoy the benefits of neutrality, and shall therefore be respected and protected by the belligerents."

260. The Americay propositiox.

Before the discussions, an American proposition was examined, which extended the exemption to the land, as well as 
the waters. "Why make commercial transit free if the markets are to be closed by war? Why neutralise a thread of water, if all the shores are to be covered with hostilities?" $(o)$. The question, Mr. Kasson explained in a memorandum, was not to "exclude the hypothesis of a war" in the conventional basin of the Congo, but to prevent European and American Powers from making it the theatre of hostilities. The colonial wars which hampered the prosperity of American colonies should be avoided in Africa. Establishments created at great expense should not be liable to be destroyed by the rivalries of foreign States $(p)$.

Sir Travers Twiss observed that "if it was proposed not to" forbid war, but to circumscribe its theatre, the proposition was a practical one."

\section{Views of the plenipotentiaries.}

The British Ambassador declared that his Government was ready to subscribe to the American proposition in its widest sense.

Count Hatzfeldt and M. de Kusserow expressed themselv:: similarly on behalf of Germany.

Tho Italian plenipotentiary was of the same opinion. $\mathrm{He}_{\mathrm{e}}$ suggested that the mediation clause inserted in Prot. 23 of the Paris Congress.might be used again and given greater efficacy in this case.

The plenipotentiary of Portugal, on the other hand, observed that Mr. Kasson's plan would impair the sovereignty of the Congo States and of the Powers having colonies there. States crossed by the boundary of the Congo basin would be subjeat to two different international régimes.

Baron Lambermont remarked that, if all that was wanted was an engagement not to make war in the basin of the Congo, Belgium would merely act in its character of a perpetually, neutral State in subscribing to it.

The French plenipotentiary, Baron de Courcel, raised serious

(o) Letter of Mr. Kasson to Mr. Frelinghuysen, dated Berlin, December 13th, 1884.

( $p$ ) See, also, Motives of the Proposition, Annex 13 to Prot. 5. 
objections. "Neutrality, he said, ean only take two forms:it is either voluntary and frea, or it is compulsory and guaranteed. The latter is not under discussion, and the former eannot be decreed. Hence the proposed measure would be without practical value. No belligerent Government having possessions in the basin of the Congo could submit to it. It cannot be asked that a belligerent State shall deprive itself of a part of its means of action. Such an engagement eould not be kept. When a State is at war, it wages war by all the means in its power. The transactional proposition concerning navigable watcreourses and roads realises all that is practicable in Mr. Kasson's plan. This proposition is already a great step in advance, since it sanctions the prineiple of the inviolability of private property, both of belligerents and neutrals, on the said waters and roads."

262. Mr. Kasson's defence of his proposition.

The plenipotentiary of the United States then undertook the defence of his plan. "It does not contemplate wars in Africa, he declared, but only foreign wars which might be transferred to Africa. It only aims at preventing the basin of the Congo from becoming the scene of conflicts that do not concern it, and at preventing belligerents from rousing the native tribes, which are already too much addicted to fighting and plunder. Our proposition, he added, is not only humanitarian, but it has a very practical meaning. We shall not make war in the Congo basin, but, for the security of our commerce and our establishments, we have an interest in no wars being brought there."

$\mathrm{Mr}$. Kasson requested that he might modify his proposition in such a way as to take account of the divergences of opinion brought to light, while retaining the fundamental idea.

263. Waters AND TERRITORIES TO BE DEALT WITH SEPARATELY.

Before this discussion was resumed, the French Ambassador proposed to disconnect the two propositions dealing with the waters and with the territories respectively. The original proposition referred to the waters only. It was to apply to the Niger as well as to tho Congo. He proposed, therefore, to fix 
the text of this article by taking the "transactional proposition" as the basis of discussion. This method was adopted. The examination of the article itself showed no essential disagreement.

\section{Amendments.}

In $\S 1$, "during a stato of war" was replaced by "in time of war" in order to widen the praetical sense of the provision.

In $\S 4$, the British Ambassador asked for the suppression of "protocted" "lest some belligerents should abuse this protection in order to gain an entrance into the establishments of the International Commission and use them for military purposes." The plenipotentiaries of Germany thought the protection might be "indispensable in ease of attacks by the natives." The abuses feared were eontrary to the idea which dictated the article.

It was agreed to mention these explanations in the report, and the final $\$$ was adopted without change.

\section{Art. 36 (XIV.).}

265. SubsequeNT ALterations possible.

Art. 9 of the draft of the committee, to the effect that "The Signatory Powers of the present. Act reserve to themselves the right to introduce into it subsequently, and by common consent, such modifications and improvements as experience may show to be expedient" was adopted as Art. 36 of the Final Act, as a general provision.

\section{The Niger.}

266. A different régine fron thit of the Congo.

We have seen on what grounds a different system from that of the Congo was elaimed for the Niger. If Great Britain declined European intervention on the Niger, while adhering to the prineiples of Vienna, it could not, however, refuse the co-operation of France which possesses part of the river. The two Powers came to an agreement and pledged themedres 
separately to adopt regulations providing for the freedom of navigation on the river, its affluents, branches and outlets, and facilitating the passage of vassels as far as possible; and promised to protect foreign merchants in the same manner as their own subjects (Arts. 30,31 of the Final Act). Every Signatory Power assumes the same obligations in ease it shall hereafter acquire possessions in the basin of the Niger (Art. 32).

Besides these articles which correspond to the articles of the Congo regulations dealing with the International Commission, the differences between the Act of the Congo and the Niger are very small, and such as follow naturally from the differences of circumstances $(\$ 336)$.

\section{The Conference of Berlin and previous Congresses.}

267. InNOVATIONS.

There is no doubt that the Conferenee of Berlin of 1885 marks an important step in the path of progress. It applies the principles of $181 \mathrm{j}$ in their most liberal interpretation, takes account of what improvements or extension they have received in their subsequent applications, notably to the Danube, and eren innovates on some important points.

Whereas the principles of Vienna applied only to such tributaries as were themselves international, the Act of Berlin extends the régime of the river to all its afluents, and even to the roads, railways, canals and lakes which are like appendages of the great waterway, itself only discontinuously navigable.

By the Final Act of Vienna, the regulation of police and navigation was entrusted to a Commission exclusively composed of delegates of the riparian States. Peculiar circumstances rendered the establishment of a European, besides the riparian Commission, nocessary for the improvement of the navigability of the mouths of the Danube. In the case of the Congo, the intention was to set up an International Commission endowed with legislative, administrative and judiciary powers and functions. This innovation was not, however, extended to the Niger, which remained under the joint control of France and England. It is also important to notice that, even for the 
Congo, the International Commission was never constituted, and that the five Powers which exercise their sovereignty over the territories bounded or traversed by the river and its affluents supervise, themselves, the application of the provisions of the Act of 1885 .

Finally, the Act of 1885 has filled an important gap by providing for the continuance of freedom of navigation for the merchant vessels of all nations, belligerent as well as neutral, in time of war. This is an important extension of the principle of the inviolability of private property in international conflicts.

\section{The PRINCIPLEN of 188.j as the UP-To-Date EXPRESSiON} of the Conventionil Law of Natioxs.

\section{Probable reason of tileir liberal char.icter.}

It remains to be seen how far the principles of 188.5 may bo considered as the up-to-date expression of the public law of nations created by the consent of nations.

The innovations and the liberality of the adopted principles were undoubtedly due to the fact that the territories concerned had not yet been submitted to the full control and sovereignty of any powerful States. On the other hand, on most of tho principles the agreement of the representatives of the fourteen nations was complete; and, apart from differences of circumstances, one would expect that they should not have different. standards for the principles of International Law according as these are to apply to others or to themsolves. Here, however, it is necessary to say a few words about the reservations which were made and about the discussions which took place in regard to the wording of the preamble of the Act of Navigation.

\section{First dRaft of the preamble.}

As it was proposed by the sub-committee, the preamble ran:

"The Congress of Vienna having established by Arts. 108 to 116 of its Final Act the general principles which regulate the free navigation of the navigable waterways which separate or traverse several States, and these principles, completed by Arts. 15 and 16 of the Treaty of Paris 
of March 30th, 1856, having by the fact of their more and more extended application to a great number of rivers of Europe and of America, and especially to the Danube, passed into the domain of public law, the Powers whose plenipotentiaries have assembled in Conference at Berlin have resolved to apply them equally to the Congo, and to its affluents as well as to the waters which are assimilated to them ....'

As Baron Lambermont remarks: "The preamble considers not only the article of the Treaty of Vienna of 1815, but it also calls to mind the onward march of the principle of protection for the free navigation of rivers, which principle it inscribes, so to speak, on the frontispiece of the instrument which is for the first time to apply it to an African river."

Objections, however, were raised from two quarters: America and Russia.

\section{Objections of the American plenipotentiary.}

The American plenipotentiary explained his objection as follows in a letter dated Berlin, December 8th, 1884, to Mr. Frelinghuysen, the Secretary of State: "The original draft involved an admission that the principles of the Congresses of Vienna and of Paris in respect to the free navigation of international rivers 'had passed into the domain of public law' "by reason of their application to a large number of rivers in Europe and America. To this I objected, as we had never. yet conceded the right of any European Congress to regulate, directly or indirectly, the rights applicable to American jurisdiction $(q)$. My scruples were respected, and the wording was changed by the Commission as indicated . . . ."

The words: "having by the fact of their more and mone extended application to a great number of rivers of Europe and America, and especially to the Danube, passed into the domain of public law" were altered into: "having received a more and more extended application to rivers of Europe and America, and especially to the Danube."

(q) But they had not hesitated to appeal to the principles of Vienna in the St. Lawrence controversy. 


\section{Objections of the Russian plenipotentiary.}

The Russian plenipotentiary, Count Kapnist, had proposed to substitute the following wording: "The Congress of Vienna having established general principles relative to the navigable rivers which separate or traverse several States, and these principles having been applied in a certain measure and with the necessary modifications under the circumstances to several rivers of Europe and America, the Powers whose representatives are assembled in Conference at Berlin, have thought it proper to extend to the Niger-Congo the application of the said principles, adapting them to the local situation."

Count Kapnist reverted to the subject at the fifth Conference. His reservations extended not only to the preamble and to several articles of the Act of Navigation (esp. Arts. 6 [see $\S 227], 12,13$ ) but also to the body of the report of the committee's proceedings, to which the Russian plenipotentiary objected as being "stamped with a manifest tendency to enlarge and generalise the bearing of the Acts relative to the Danube, as wel! as the resolutions of the present Conference, and to establish these Acts and these resolutions as doctrines of public law"-an evil tendency to which the plenipotentiary declared that the Russian Government could not subscribe (cp. \$273). Count Kapnist adduced the following proofs of this tendency: (1) tho application of the epithet "sovereign" to the European Commission of the Danube; $(2)$ the following sentence in a short historical retrospect: "It was, howerer, reserved for the legislation with regard to the Danube to sanction, definitely, the maxims that now regulate river navigation;" (3) the two following" passages: "Art. 4 introduces into International Law a new idea which will be regarded as an improvement;" and "the decision which the Conference is ealled upon to take in this respect will make, no doubt, an epoch in International Law." Count Szechenyi (Austria-Hungary) and M. Bush adhered to these views.

272. Baron Lambermont's REPLT.

Baron Lambermont, replying to these objections, concluded: "As for the tendency of the report to present the arrangements 
elaborated by the Conference as constituting an advance in point of modem public law, he believes it corresponds to the general opinion of the members of the committee."

273. Solfm Reservations of the Russian plenipotentiary.

As to the preamble, Count Kapnist, though glad to sø that notico of his project of modification had been taken, objected to the words " and especially to the Danube." To elear away erentual misunderstandings, he said:

"In the opinion of the Imperial Grovernment of Russia, the prineiples of the Congress of Vienna, as to the liberty of river navigation, have not been applied to the Danube in conformity with the spirit and letter of several essential provisions of the Final Aet of that Congress. On the contrary, the stipulations of this Act have been made to suffer exceptions in their application to the Danube.

"Very peculiar circumstanees necessitated this exeeption to the rule.

"It was necessary to drolge the mouths of the river at a time when the riparians were vassal prineipalities which had not the means to carry out the work at their orn cost. Therefore an international or European Commission was substituted for the riparian Commission intended by the Aet of the Congress of Vienna. The European Commission has not ceased to preserve the temporary character. whicl: it had at its beginning (see the article of the Treaty of Paris cited in the preamble), so much so that to-day its existence can be prolonged only on condition of the general ascent, and, among others, of that of the riparian Powers, given every five years $(r)$.

"Besides, ean a single example be eited of the application to the rivers of Europe of Arts. 15 and 16 of the Treaty of Paris? I doubt it, though it is implicitly affirmed in the preamble that such rivers exist, since formal mention is made therein of the application of the principles of

(r) Inaccurate: It is prolonged by "roconduction tacite" every three years (§ 175). 
Vienna, 'completed ' by the aforesaid article, 'to the rivers oi Europe, and of America, and especially to the Danube.'

"Let me then be permitted to observe with regard to this, that, with reference to the Congress of Vienna, the system of an International Commission is, in general, an excoptional one and in no way the application of the rule.

"What we are doing for the Congo is consequently also an exceptional systen, necessitated by the peculiar conditions in which this country finds itself.

"The best proof of it is the fact that the Niger is subjected to an absolutely different régime.

"The Government which I have the honour to represent here joins willingly in this peaceful and civilising work, but insists that this work should preserve the exceptional character which is proper to it, and I am authorised to declare that, far from wishing to generalise its scope, my Government only accepts the arrangements and the prineiples of the Act of Navigation in question, on the understanding that its application is expressly limited to the regions of Africa which form the object of the present Conference."

274. 'THE PREAMBLE IS ADOPTED WITII TWO MODIFICATIONS.

Count Kapnist also objected to the words "more and mors extenderi application." After an exchange of opinions, the following modification was adopted: "having been appliod to rivers of Europe and America, and especially to the Danube, in virtue of the Treaties of Paris, 1856, of Berlin, 1878, and of London, 1871 and 1883.'

Then, in compliance with M. Kasson's observations ( $s$ ), it was proposed to substitute for: "the general principles which regulate free navigation" "the principles designed to regulate free navigation between the Signatory Powers of this Act."

The preamble was put to the rote and adopted with the two modifications above indicated.

(s) " Ile did not wish that it might be concluded that the Congress of Vienna had the right to establish rules obligatory for the whole world; the principles which it proclaimed were only binding on those Powers which took part in its deliberations" ( $\$ 270)$. 


\section{III.-Conclusions: A Standard Regulation.}

275. The assent of The CIVILISED WORLd $(t)$.

The solemn reservations of Russia show once more that the stumbling-block for the practical solution of our problem lies in the sovereign rights of the riparian States. The protest is levelled at non-riparians' sharing in the executive authority on international rivers; it does not in any way affeet the great principle of free navigation for all flags, on a footing of perfect equality for riparians and non-riparians on international rivers.

This principle, which had been elearly proclaimed by the peace makers of 1814 (Treaty of Paris, Art. 5), was not denied by the authors of Art. 109 of the Final Act of the Vienna Congress of 1815 ; it was only obseured by an ambiguous wording.

In 1856, it was strongly reasserted in the Treaty of Paris, and it encountered no opposition at the Conference of Berlin of 1885 .

It is now generally admitted as a principle of International Law by the eivilised world; and the admission may be asserted to be less owing to the fear of retorsion, than to the gradual recognition among nations that it is to their own greatest interest for all of them to contribute, to the utmost of their power, towards the extension of international relations and world traffic $(\$ \S 25,26)$.

One may thus say that the opening of all international rivers to all flags equally is at present a necessity recognised by all civilised nations.

It is then perfectly true to say that henceforth, to use sir. Edward Malet's very words at the first sitting of the Conference of Berlin: "the question for practical consideration will be not so much the acceptance of the general principles as the morle of their application" (\$ 183). 


\section{The PRACTICAL QUESTION.}

But it is not enough for principles to be proclaimed in treaties. Our excursion among regulations shows this conclusively. The study of the opening up of international rivers therefore includes the mass of administrative regulations as well as the work of diplomacy. The latter leads in three stages to the triumph of the generous principle of complete freedom; the former which is, so to speak, less exalted but more realistic, is infinitely complicated and intricate: it consists in the mazes of regulations where, as we have seen, legions of egoistical and particularistic interests are lurking ready to dispute every inch of ground with the advancing general interest.

Before the general interest can be left at the mercy of the good or ill-will of these particularistie interests, it is obviously necessary to take all imaginable precautions to secure the most loyal execution of the adopted prineiples. To this end, a formula declaring freedom of navigation for all, "subject to the regulations to be made by the riparian Governments among themselves, not inconsistent with the principles set forth in this treaty" $(u)$, might be commendable. But this is not enough. After having proclaimed freedom of navigation, it is necessary to make it effective by ridding navigation of all needless administrative hindrances and fiscal burdens. Here it is above all important not to be rebuffed by the complexity of the problem. The elaboration of all the prineiples-and at every stage we see their number increasing in the general treatiesby special committees of specialists and statesmen, is recognised to be a necessity ( $\$ \S 47$ and note; 184-186). The prineiples no longer being questioned, it remains to persevere in propagating, and ensuring the application of, the best methods of execution.

277. The: Regulation of Heidelberg.

The comparative study of conventions and regulations has made it possible to evolve rules which it would be useful to

(u) Cp. Art. 26 of Treaty of Washington, May 8th, 1871, concerning the St. Lawronce. 
generalise. Thus in 1887, at the meeting of Heidelberg, the Institute of International Law fixed upon a standard regulation which seems to us to contain the best method's and the most appropriate rules for the navigation of international rivers.

This regulation sums up the general principles and gow into the details of their application. It is an excellent source of inspiration for all who are called upon to inquire into the most appropriate rules to be applied to the navigation of internationa? rivers; it seems therefore to us to be the logical, as well as the practical, conclusion of our work. For this reason, we translate it here, adding a few comments and copious references to the precedents and discussions of which we have taken notice in our study.

\section{General provisions.}

278. Compulsory igreement.

"Art. 1.-The riparian States of a navigable river ane obliged, in the general interest, to regulate, by common agreement, everything relating to the navigation of such river."

Cp. $\S 67$, the wording of Art. 108 of the Final Act of the Congress of Vienna. For the simple engagement to regulate navigation by common agreement, the present article substitutes the obligation of doing so in the general interest.

279. Navigable afFluents.

"Art. 2.-The navigable affluents of international rivers are, in every respect, subject to the same régimo as the rivers whose tributaries they are, in conformity with the agreement concluded between the riparian States, and with the present regulation."

Cp. wording of Art. 110 of Final Act of Vienna ( $\$ 69$ ). It applies the rules for the collection of dues and for river police to international affluents, with a reservation. The present article extends in every case the whole régime of the river to all its navigable affluents, whether national or international (cp. § 207). 
280. THF PRINCIPLE OF FREE NAVIGATION.

"Art. 3.-The navigation on the whole course of international rivers, from the point where each of them becomes navigable, to the sea, is entirely free, and cannot, as regards commerce, be forbidden to any flag."

The ambiguity of Art. 109 does not exist here, chiefly owing to Art. 4. "As negards commerce" simply excludes warships (cp. $\$ \S 11,13,16,53,68,79,93,121,135-137,174$, $182,188,190,192,284)$.

\section{BOUNDARY RIVERS.}

"The boundary line of the States separated by the river is marked by the Thalweg, that is to say, by the middle line of the channel."

This paragraph gives an unsatisfactory definition of Thalweg: as it may lead to a confusion with middle line. The following explanations seem therefore necessary.

\section{Middle Line.}

When a river forms the boundary between two States, where exactly is the line of demarcation to be drawn?

The analogy of the rule of Roman Private Law for the delimitation of properties was first resorted to. A boundary river was generally presumed to be common, and the jurisdiction of the two States extended to the middle of the stream $(x)$. This system, long retained, entailed great inconveniences: (1) as the width of the river depends on the level of the water, and as the banks are not necessarily of the same height, a larger space may become uncovered on one side than on the other, and so the middle line may shift. This may happen to such an extent that islands may be in turn on the right and on the left side of the line; (2) furthermore, the deep part of the river might be entirely on one side, thus possibly depriving one riparian State of the beneficial use of the river.

(x) See interesting Art., E. Nys, R.D.I., 2e série, p. 75 sq. 


\section{Thalweg.}

To remedy these inconveniences, the system of the Thalweg. (downward way) makes its appearance, displacing the limit from the surface of the water to the alveus.

The notion is said to have been proposed and elaborated at the Congress of Rastadt, 1797 (cp. Art. 6, Traité de Lunéville, 9th February, 1801).

An authoritative definition was given in the "Convention de Strasbourg," 1827. Thalweg is the proper course taken by boats going down stream at low water; in case of contest between two branches, the one whose Thalweg is deepest is the "branch of the Thalweg." This solves the questions relative to islands.

Ern. Nys (1. e.) insists on using the words "axe du Thalweg" for greater precision, meaning by that the uninterrupted line determined by the deepest places in the bed. But, as Ed. Engelhardt points out (Reg. Conv., 18r9), it is generally thought sufficient to observe the course of ressels of high tonnage and to indicate it by means of buoys and fixed rignals.

The system of the Thalweg has the advantage of offering greater stability than the middle line of the stream; but with the progress in hydrotechnies, both now mostly coineide.

The stability of the Thalweg is, however, by no means eomplete. If the Thalweg changes, it causes a shifting of tho boundary line; but it is settled that, when a river abandons its normal bed, the boundary is not thereby changed.

284. EQUAL TREATMENT for ALL.

"Art. 4.- The subjects and flags of all nations are in every respect on the footing of perfect equality. No distinction shall be made between the subjects of riparian States and those of non-riparian States."

To admit of differential treatment is to open the door to abuse. The principle of this article was enunciated in 1839,1856 , and at Berlin in 1885 (c). $\$ \$ 93,121,189,190,201,211$ ). 
285: Navigation Dues.

"Art. 5.-The navigation dues levied on international rivers shall have, for their exclusive object, to cover the cost of the works for the improvement of these rivers and of the maintenance of their navigability in general."

Cp. Art. 4 of the Vienna Regulations for the Rhine, 1815 ( $\$ 56$, and especially note 1 ). Cp. also $\$ \S 46,50,87$ esp. note, $121,196,203$.

286. Navigation free for neutrals in time of war.

"Art. 6.-In time of war, the navigation of international rivers shall be free for the flags of neutral nations, subject to such restrictions as may be imposed by the force of circumstances."

See $§ \S 254,258,259$. Cp. Art. 40.

287. Protection of establishments and Personnel. in time OF WAR.

"Art. 7.-All the works and establishments created in the interest of navigation, notably the offices for the collection of dues, and their safes, as also the staff permanently in the service of these establishments, are placed under the safeguard of permanent neutrality, and shall, in consequence be respected and protected by the belligerent States."

The Convention of $180 t$ contained a similar provision, which the Congress of Vienna reproduced in the Rhine regulations. Many subsequent conventions contain similar provisions. Cp. $\S 42,62,142,145,162,219,224,257$.

\section{Special provisions.}

288. Coasting trade.

"Art. 8.-Any sailing ressel or steamer, without distinction of nationality, is free to carry passengers or goods, or to tow other vessels between all the ports situate along international rivers.

K. 
"Foreign vessels, whether fluvial or sea-going, shall not bo admitted to the regular exercise of small coasting trade (petit cabotage), i.e., the continuous and exclusive traffic between ports of the same riparian State, except in virtue of a special authorisation by that State."

The article rightly distinguishes between "grand et petit cabotage." The States which endeavour to reserve the "grand cabotage" to their own subjocts disregard the principle of the equal treatment of riparians and non-riparians. This does not seem to be the case with regard to "petit cabotage." By reserving the right to regulate it, each riparian State only ensures the existence and development of local transports necessary to its prosperity and perhaps to its own existence. This reservation does not materially infringe the principle which the treaties intended to establish. However, Art. 1 of the Act of Navigation of the Congo (1885) prohibits even the reservation of the small coasting trade.

Cp. $\S 128,133,134,189,288,306,308,315$.

289. Fre: transit.

"Arí. 9.-Vessels and goods in transit on international rivers are not subject to any transit duty, whatever their origin or destination."

This provision is completed by Art. $20, \S 2$.

Cp. $\S \S 12,87,95,178,195$.

290. Prohibited duties and tolls.

"Art. 10.-The navigation of international rivers is exempt from staple duties, port dues (échelle), storehouse duties (dépôt), compulsory breaking bulk or forced harbour duties. No tolls, whether maritime or fluvial, shall be levied."

Cp. §§ 60, 73, 93, 94, 194, 196.

291. Permissible dues and duties.

"Art. 11.-There may be levied dues or duties having the character of a reimbursement for the actual use of 
harbour establishments, such as cranes, weighing machines, wharves and warehouses."

In fact we deal here with remuneration for servicas.

Cp. $\S 61,87,197-202$.

"Art. 13.-The harbour dues for the actual use of cranes, weighing machines, \&c. . . ., as also the dues for pilotage, lighthouse, lighting and buoying, destined to cover the technical and administrative expenses incurred in the interest of navigation shall be determined by tariffs officially published in all the ports of international rivers."

"Art. 14.-The tariffs above mentioned shall be drawn up by the 'mixed commissions' of the riparian States."

"Art. 15.-The tariffs shall not involve any differential treatment."

"Art. 16.-The tariffs of the dues mentioned in Art. 13, shall be calculated on the cost of construction and maintenance of the local establishments, and according to the tonnage of the vessels as indicated in the ships' papers.

See Art. 39, § 303 .

\section{Customs, etc.}

Tho question is how to prevent the Customs from inter fering with navigation, without prejudice to the measures for the prevention of smuggling (cp. $\$ \S 39,50,61,74,17 \times)$. Hence the following provisions:

"Art. 12.-The customs duties, octroi duties or taxes on consumable articles established by the riparian States shall not in any way hinder navigation."

"Art. 17.-The riparian States may not levy customs duties on merchandise in transit on international rivers, except when it is to be introduced into the territory of theso States."

Cp. § 178 .

"Art. 19.-Vessels proceeding on their voyage and provided with the prescribed papers may not be stopped under any pretext by the customs-officers of the riparian States, if the two banks belong to different States."

Cp. Art. 6 of the regulations for the navigation between 
the Iron Grates and Ibraïla annexed to the Treaty of London, 1883 (\$ 178).

"Art. 20.-Vessels entering into a part of an international river where the two banks belong to the same State, have to pay the customs-duties imposed by the local tariff upon merchandise imported into the territory of that State.

"Groods in transit are only subject to the placing of seals and to the custody of customs officers."

Cp. $\$ 289$, on free transit.

"Art. 18.-Vessels are not allowed to unload their cargoes, either wholly or in part, except in ports and other places on the banks provided with a custom-house, save in case of necessity (force majeure).'

The creation of free ports (ports franes) or free warehouses might be recommended. Such warehouses are particularly necessary where maritime navigation generally stops or where natural obstacles render transhipment or unloading necessary.

Cp. $\$ \$ 87,88,95$ (c) and (d).

293. Police regulations.

"Art. 21.-The riparian States shall fix between themselves upon a body of police regulations destined to regulate the use of the river in the special interest of security and public order." (See Art. 30 (3), § 299, and Art. 32, § 300.)

This provision is necessary for the unification of the fluvial régime.

Cp $\$ \$ 40,49,50,56,64,68,69,119,146,230$.

294. Quarantine.

"Art. 23.-Quarantine establishments shall be created, by the initiative of the riparian States, at the mouths of international rivers; control is to be exercised over vessels both when they enter and when they leave the river.

"Sanitary control over vessels, while they are navigating the river (dans le cours de la navigation fluviale), is exer- 
cised on the basis of the special provisions established by the riparian Commissions."

The riparian States have, of course, the right to take sanitary measures of protection; but it is intolerable to see the exercise (or abuse) of this right rendering illusory the principle of equal treatment of riparians and non-riparians.

A general quarantine establishment at the mouth of a river and placed under the joint control of all the riparian States is in every case to be recommended.

Cp. $\S 93$ (3), 94, 98, 119, 130, 133, 134, 140, 142, 162, 230, 239, 252, 253.

\section{Thl: usf of the stream.}

Regulations have not hitherto generally dealt with the question of the use of the stream for industrial and agricultural purposes. It is, howerer, indispensable to forbid: (1) the injurious pollution of the water, notably by the discharge of industrial rosidues: (2) such drawing of water, for hydraulic exploitation, \&c., as may influence the course or navigability of the river; (3) the construction of works or weirs which might cause inundations in the territory of a co-riparian; (4) and, generally, all interference which may cause modifications of the actual condition of the waterway, except by the common agreement of all the riparians.

This question was examined by the "Institut de droit International" at the sitting of Madrid (1911), where the following rules were adopted:

"I. Where a watercourse forms the boundary between two States, neither of these States may, without the consent of the other, and without a special and valid legal title, make, or allow individuals, corporations, ete. . . . to make alterations to it detrimental to the bank of the other State. On the other hand, neither of the two States may, on its own territory, utilize, or allow to be utilized, the water in a manner which may seriously interfere with its utilization by the other State or by individuals, corporations, etc. . . thereof.

"The foregoing provisions are likewise applicable to a lake 
lying between the territories of more than two States. [Why not "of two or more States"?]

"II. When $d$ " watercourse traverses in succession the territories of two or more States:

"1. The point where that watercourse crosses the boundary of the two States, either naturally or since time out of mind, may not be changed by the establishments of either of the States without the consent of the other.

"2. All injurious pollution of the water and discharge of noxious matter (from factories, etc.) is forbidden.

"3. It shall be forbidden to any establishments (especially factories utilizing hydraulic power) to divert such quantities of water as may seriously alter the nature, or in other words the essential character or utilizability of the watercourse at the point where it reaches the lower territory.

"4. The right of navigation by virtue of a title recognized in international law may not be violated in any way whatever (par un usage quelconque).

“5. A lower riparian State may not erect, or allow to bo erected, within its territory, any constructions or establishments subjecting the other State to the danger of inundation.

"6. The foregoing rules are likervise applicable to the case of watercourses flowing from a lake situate in the territory of one State into the territory of another or of several other States.

" $\tau$. It is recommended that the States interested should appoint permanent joint commissions which would give decisions, or at least give their opinion, when the construction of new establishments or the alteration of existing astablishments might have important consequences for the part of the watereourse situate in the territory of another State" $(y)$.

(y) The "Exposé des Motifs" which precedes these rules has not yet been sabmitted to the vote of the Institute. It is, however, interesting. It runs:

"The riparian States of the samo watercourse are in a condition of per- 
296. WoRkS FOR THE MANTENANCE AND IMPROVEMENT OF THE NAVIGABILITY.

Here also, the common agreement of the co-riparians is desirable to ensure unity of action and uniformity of technical schemes.

A riparian State must never lose sight of the fact that it is not alone concerned, but must take into eonsideration the interests of its co-riparians.

Cp. $\$ \$ 59,72,88,236$.

For very extensive works, the expedient of the European Commission of the Danube has incontestably produeed good results ( $\$ \S 141,218$ ).

Bridges must be so built as not to hinder navigation ( $\$ 88$ ).

Concerning the four articles which follow, it might be asked whether it would not be preferable to require common agreement beforehand in every casc, instead of the provisions of Art. 26. This would be in conformity with Art. 30 (1), according to which the riparian Commission designates and provides for the execution of the works indispensable for improving and developing the navigability of the river.

"Art. 24.-The works necessary to ensure the navigability of international rivers, are to be undertaken either directly by the [riparian] States or on the initiative of the riparian Commissions."

manent physical dependence on one another, which excludes the idea of the complete autonomy of any one of them on the part of the natural watercourse under their respective sovereignty.

"Although international law has dealt with the right of navigation on international rivers, it has as yet made no provision concerning the utilization of the water for manufacture, agriculture, ete. (l'exploitation ... est restée en dehors des prévisions de ce droit).

"It appears opportune, therefore, to supply this deficiency by stating the rule: of law which result from the interdependence which incontestably exists between States bordering on the same watercourse, and between States whose territories are traversed by the same watereourse.

"Without prejudice to the right of navigation in so far as it is already, or shall be, regulated by international law:

"Tho Institute of International Law is of opinion that the following rules should be observed with regard to the utilization (in any way whatever) of international watereourses." 
"Art. 25:-Each riparian State shall be free to take such steps as it may think necessary to maintain and improve, at its own expense, the navigability of the sections of international rivers subject to its sovereignty."

"Art. 26.-In every case, it shall be forbidden to undertake works which may modify the actual condition of the common waterway (modifier l'économie des eaux communes) or impede its navigation, and against which the other riparians have protested."

"Art. 38.-Each riparian State appoints the engineers charged with supervising the maintenance and improvement of the section of the river subject to its sovereignty."

297. The executive authorities.

"Art. 27.-The authorities set over the navigation of international rivers are: (1) the authorities of the riparian States; (2) the riparian Commission, composed of the delegates of the sovereign States."

298.--I. Rights of sovereignty.

"Art. 28.-Each riparian State retains its sovereign rights over the sections of international rivers subject to its sovereignty, within the limits laid down by the stipulations of this Regulation and by the treaties and conventions.'

Cp. $§ 17-20,23,42,50,81,91-92,103,134,139,155$, 162-163, 173, 179, 184, 220-223, 232, 241, 261.

299.-Hi. Riparian Commission.

"Art. 29.-The riparian Commission arrives at its decisions by a majority of rotes. In case of equality, the president has the casting vote.

"However, a vote does not bind the States whose representatives form the minority, if, beforehand, the delegates of these States have formally objected to the execution of the measure proposed."

"Art. 30.-The riparian Commission is a permanent 
authority over international rivers; it has the following functions:

"(1) to designate and have executed the works indispensable for improving and developing the navigability of the rivers;

" (2) to draw up and put in force the tariffs of navigatior: and other dues mentioned in Arts. 13 to 18;

" (3) to elaborate the regulations for river police (\$ 293);

"(4) to watch over the maintenance in good condition of the works, and the strict observance of the provisions of these international regulations;

" (5) to appoint the chief inspector of the navigation of the international river" (cp. Art. 37, \$ 301).

Cp. $\$ \S 49,59,67,80,100$ (4) (5), 105, 109 (IV.), 111, 122, 131.

300. The inspectors.

"Art. 31.-The chief inspector exercises his functions as the organ of the riparian Commission and under its direction. He exercises his authority over all flags without. distinction."

"Art. 32.-The chief inspector watches over the application of this international regulation and of the river' regulation, and supervises the police of navigation."

"Art. 33.-This functionary has the right, in the prerformance of his duties, directly to demand the assistance of the military posts or of the local riparian authorities." (Sae Art. 36, § 301.)

Cp. $\S 59,93,96,142,241$.

"Art. 34.-The local inspectors, the quarantine officials and the employees of the offices for the collection of dues are appointed by each riparian State; but they perform their duties under the orders of the chief inspector, and have, like him, an international character." 


\section{Tribunals.}

"Art. 36.-The chief inspactor pronounces, in first instance, the penalties to be inflicted for infractions of the regulations of navigation and police."

"Art. 22.-Special tribunals of navigation, or the ordinary courts existing in the riparian countries shall, on appeal, be competent to adjudge the penalties (connaîtront, en appel, des pénalités) for infractions of the police regulations established on a footing of perfect equality for all vessels, without any distinction of nationality whatever." This provision is qualified and completed by Art. 37. It emphasises the principle of equality of treatment for all flags.

"Art. 37.-Appeals against his (i.e., the chief inspector's) judgments must be brought either before a tribunal of navigation created for that purpose, or before a local court specially designated by each riparian State, or before the riparian Commission."

The inconvenience of leaving the settlement of disputes to a central administrative authority has been pointed out, such an authority being at the same time a party and the judge. (See Art. 35, \$ 30\%.)

C\}. $\$$ เ $41, \tilde{5} 8,82,142,146,232$.

302. Mutull AgreEMENTS FOR NOMINATIONS.

"Art. 35.-Two or more riparian States may make inutual agreements for the nomination of the same delegate to the riparian Commission or of the same local inspector, or of the employees of the offices for the collection of dues, of the quarantine officials, of the judges of the tribunals, \&e. . . ."

303. Measurement of tonnage.

"Art. 39.-The Powers shall fix by common agreement the system of measuring river and sea-going vessels for the purpose of ascertaining their tonnage (le système de mesurage et de jaugeage pour l'évaluation de la capacité des bâtiments fluviaux et maritimes)-this system being obligatory for all nations.' 
M. Ed. Engelhardt proposes as unit the English ton, and as wethod of measurement the system of Moorson as described in the Merchant Shipping Act of 1854 .

Cp. $\S 40$.

304. Floating properti in the of wak.

"Art. 40.--In case of war between the riparian States, all property afloat on an international river, without distinction between neutral and enemy property, shall be accorded similar protection to that granted to enemy property in case of war on land (sera traitée suivant l'analogie de la protection de la propriété ennemie en cas de guerre sur terre)."

Cp. $\$ 261$.

In his elosing speech at the Conference of Berlin, in 1885, Prince von Bismarek observed "that the work of the Conference, like all the other works of man, may be improved and completed." This reflection will strike everyone who may hereafter examine this our question. Much progress has been made; but much room is still left for improvement, either immediate or future. And among the undertakings which deserve our utmost care and attention, we must surely place those which, in order to bring nations together, foster mutual good-will by making it profitable to all. 
IN'TERNATIONAL RIVERS.

\section{APPENDIX I.}

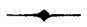

\section{NOTES ON O'THER EUROPEAN RIVERS.}

\section{A.-Applications of the Principles of Vienna.}

(a) The Elbe.

305. Congress of Vienna.

A treaty of peace and friendship between Prussia and Saxony, signed in Vienna on May 18th, 1815, and annexed to the Final Act of the Congress (Annex 4) provided (Art. 17 that the general principles adopted by the Congress with regard to the free navigation of rivers should be applied to the Elbe and certain of its affluents. To this end, commissaries appointed by the sovereigns of the two kingdoms met in Dresden and fixed the bases of a first partial convention which was signed on August 28th, 1819 .

306. Convention of 1821.

The principle of Art. 1\% was not, however, completely realised until 1821 (June 23rd), when Prussia, Austria. Saxony, Hanover, Denmark (acting for Holstein and Lauenburg), Mecklenburg-Schwerin, Anhalt-Bernburg, the Coethen and Dessau and the free town of Hamburg signed a convention. whose object is described as follows: "The Act of the Congress of Vienna, of the 9th of June, 1815, having established tht general principles according to which the navigation of rivers is to be regulated, the riparian States of the Elbe, animated with the desire of realising, as soon as possible, the advantages and facilities which are thereby ensured to commerce, have agreed that a Commission should assemble at Dresden for the purpose of fixing, by common agreement, the necessary pro- 
visions with regard to the navigation of the Elbe" (Preamble, Brit. and For. St. Pap., VIII., 953).

The first article of this convention provides that "The navigation of the Elbe shall be entirely free with respect to commerce," but reserves to the riparian subjects the coasting trade between the riparian States.

Art. 2 abolishes the privileges hitherto granted to "companies of boatmen and other bodies, or to individuals." However, "ferries and other established modes of conveyance from one bank of the river to the other," and concessions made by a sovereign to his subjects within the limits of his own jurisdiction, are excepted.

Art. 3 suppresses "all storehouse and forced harbour dues," whence it follows that no captain can be forced to unload his vessel against his will.

The exercise of navigation is conditional upon the possession of a licence; and Art. 6 authorises arrangements between two towns for a regular service of transport between them.

Art. 7 provides that "all tolls hitherto collected on the Elbe, as well as all other taxes under any denomination whatsocver, with which the navigation of the river has been burdened, are abolished; and in their place a general navigation due is to be paid on all vessels, timber floats and cargoes at the collectionhouses designated in the present eonvention $(a)$. This due, which shall not be farmed out, either wholly or in part, shall be levied either upon cargoes, under the denomination of 'Elbe toll,' or upon vessels under that of 'droits de reconnaissance' (Recognitions-Gebühr).'

This due shall not be modified except with the consent of all the riparian States (Art. 13). It does not exclude customs duties, import duties or consumption duties levied by the several States in their respective territories, or charges for the use of cranes, bridges, locks, weighing-machines and warehouses, these being a remuneration for services rendered.

(a) From thirty-five they were reduced to fourteen by Art. 16 . 


\section{The "Stade" tolls.}

Art. 15 states an important reservation: By it, and without. prejudice to the general principles contained in the Act of the Congress of Vienna concerning river navigation, the parties agree, with reference to the Brunshausen (or Stade) tolls, to renounce all further discussion, in consideration of Hanover having formally engaged to lay the tariff of the same before the Commission, and not arbitrarily to augment it without the consent of the States interested therein and especially of the frec vity of Hamburg.

The King of Denmark and the free city of Hamburg reserve to themselves all the rights resting upon existing customs and conventions, so that in respect of the Stade tolls they preserve the res integra.

This question of Stade, or Brunshausen tolls, gave rise subsequently to long and complicated negotiations.

It had been agreed that the applications of the above provisions to the tributaries of the river should depend upon separate arrangements between the several States (Art. 32); that the convention should be brought into force as from January 1st, 1822 (Art. 33); and that a Commission should assemble from time to time in order eventually to revise the tariffs, to set at rest the difficulties which might arise between the riparian States, and to propose such measures as experience might suggest (Art. 30).

By a convention dated April 13th, 1844, this Commission was empowered to discuss and to fix the tariff of Stade under the same conditions as the due established by Art. 7 of the Convention of 1821. This was a first step in alteration of Art. 15 above quoted.

In tho same year, Hanover, which had thus given up to the Elbe Commission the privileges which it had reserved in 1821, and had engaged to concede to its co-riparians every other privilege: which it could grant, inserted in a Treaty of Commerce and Navigation with Great Britain (signed in London, on July 22nd, 1844. Brit. and For. St. Pap. XXXII., 8) the 
following clause: "From October 1st, 1844, with regard to the so-called Stade or Brunshausen toll, no other or higher dues or tolls shall be levied on British ships-or their cargoes-passing up the Elbe to the point where the tolls of the Upper Elbe commence-i.e., up to and including Hamburg-than the dues and tolls spesified in the Convention between the riparian States of the Elbe, signed at Dresden on April 13th, 1844."

Two months later, the benefit of this clause was extended to Germany, Prussia, Sweden and Norway, Belgium, the United States of America and Mexico (Convention of September 8th, 1844, signed in Hanover). And a few days later, on September 26th, it was extended to Denmark and the free eity of Hainburg.

Other improvements followed. On June 22nd, 1861, a treaty was concluded in Hanover, by which the King of Hanover engaged, in consideration of an indemnity of $2,857,338 \frac{2}{3}$ thalers (German)-of which 1,033,3331 was paid by Great Britain-not to levy Stade tolls any longer on the vessels of the Contracting Powers $(b)$. But the Stade tolls were to continue to be levied on the ships of other nations, unless they baxame parties to a new convention.

In execution of this treaty, the fifth revising Commission consisting of delegates from all the riparian States of the Elbe assembled in Hamburg. The result of their deliberations was embodied in a convention of April 4th, 1863.

Art. 1 of this convention reads thus: "Instead of the Elbo tolls aprertaining to the separate riparian States of the Elbe according to the Act of 13th April, 1844, additional to the Elbo Navigation Act of 23rd June, 1821, inclusive of the equivalent for the recognition dues, there shall be only one Elbe toll levied in Wittemberg for all the riparian States together, according to the following conditions.'

This toll was to be levied by an administration common to Hanover, Denmark and Mecklenburg (Art. 8) and to be divided

(b) i.e., Great Britain, Austria, Hungary, Belgium, Brazil, Denmark, Spain, France, Mesklenburg-Schwerin, Holland, Portugal, Prussia, Russia, Sweden and Norway, the free and Han extic towns of Lubeck, Bremen and Hamburg (Hertslet, Commercial Treaties, XI., 355). 
between the co-riparians. In case the three States entrusted with the collection of dues did not get a certain minimum for their share of the proceeds, the other riparian States engaged to indemnify them. (For the details of these arrangements, sec St. Pap., LV., 938 sqq.).

But this state of things did not last long. On June 22nd, 1870, a treaty was signed in Vienna by Austria and the North German Confederation, which put an end to the Convention of 1863. It provides in Art. 1 that: "On and after July 1st, 1870 , tolls shall be levied on the Elbe upon ships and their eargoes, and upon rafts, only for the use of certain special appliances designed for the facilitation of traffic." And Art. 2 decides that the Convention of 1863 concerning the administration and imposition at Wittemberg of the Elbe dues held in common shall cease to have force on and after July 1st, 1870.

Although very complicated, the contents of these conventions are not devoid of interest, for they show to what an extent the questions relative to international rivers have sometimes been considered as fiscal problems $(c)$; and how much greater has often been the difficulty of settling the fiscal part of the question than that relating to the principle of free navigation.

\section{(b) The Weser.}

308. An Act of Navigation was signed at Minden on September 10th, 1823 (Martens and Saalfeld, N. R. VI., Part I., p. 301 sqq.) between Prussia, Hanover, Hesse-Cassel, Brunswick, Oldenburg, Lippe and the free city of Bremen. Its object, according to the preamble, was to apply the principles of the Congress of Vienna to the Weser, while taking into account all the circumstances peculiar to it.

Art. 1 runs: "The navigation of the Weser from its source at the confluence of the Werra and the Fulda, to the sea, and vice versâ from the sea upwards, shall be entirely free with legard to commerce; however, the navigation from one riparian State to another ("cabotage ") remains open exclusively to the

(o) Another striking, though much earlier instance is the Convention of 1 sot coneerning the Rhine. 
subjects of the said States throughout the whole river. On the other hand, no one shall evade the provision which the present convention contains as regards commerce and navigation."

Art. 2 abolishes all exelusive privileges, whether formerly enjoyed by corporations or by individuals. Are excepted, however: (1) ferries and other modes of conveyance for the passage from one bank to the other; (2) boatmen exereising their business entirely within the territory of their respective sovereigns. With respect to them, the sovereign rights of each State remain unaffected by the convention.

By Art. 3, "all duties of staple and of breaking-bulk, which hitherto existed, viz., in Bremen, Minden and Münden, are without exception for ever suppressed; and in future no eaptain shall be foreed on such grounds, and contrary to the provisions of the present convention, to unload or tranship cargoes agaiust, his will.'

We may also mention Art. 9 forbidding to impose new restrictions on ships coming directly from the sea; Art. 14 abolishing former dues; Art. 15 stipulating for the new dues and the way in which the riparian States are to share the. proceeds; Art. 16 indieating where the collection of dues is to tako place.

On the day when this convention was signed at Minden, separate conventions were made between Hanover and Bremen, and between Prussia and Bremen. They related to the application of Art. 15 of the principal convention (supra), which was renderec. difficult by a treaty of August 26th, 1769 between Minden and Bremen. The separate eonventions, accordingly, established the bases of an experiment which, after five years, would enable Minden to renounce the advantages conceded by the Treaty of 1769 .

In execution of Art. 55 of the principal convention which provided for the revision from time to time of the provisions by a Commission, several revisions took place.

In 1825 , December 21st, the navigation dues were reduced.

In 1856 . January $26 \mathrm{th}$, "in order to foster commereial relations between the States of the Zollverein and Bremen, and to 
facilitate traffic on the Weser" (preamble), a treaty betwoen Prussia, Hanover, Hesse-Electorale on the one hand, and Bremen on the other, provided by Arts. 1 and 3 for the suspension of the tolls on the Weser for the duration of the treaty of commerce and navigation of the same date between Prussia, Hanover, Hesse, in their own name and in that of the ather States of the Zollverein on the one hand, and the free and Hanseatic city of Hamburg on the other (Martens and Samwer. N. R. G., XVI., p. 429 sqq.).

Art. 18 of the latter treaty provided that its duration was provisionally fixed until the end of December, 1865; if, however, it was not denounced by any of the contracting partics at the latest on y year bafors, it would be in force for anothir twelve years, then again for another twelve years, and so on.

\section{(c) Rivers and Canals of Poland.}

309. Congress of Vienna.

The Final Act of the Congress of Vienna eontained, in its Art. 14, a provision reating to tha "fres navigation of the rivers and canals throughout the whole territory of Ancient Poland" and enjoining that the prinsiples set forth in this respect in the treatios mads in Vienna on May 3rd, 1815, beiween Austria and Russia and between Russia and Prussia "Le invariably maintained."

Iet us then inquire what those prinsiples are.

In the treaty between Russia and Prussia (Annex II. to the Final Ac: of the Congress of Vienna) we read, in Art. 22: "The navigation of all the rivers and canals of all the parts of Aneient Poland (year 1772), throughout their whole course as far as the mouth, whether downwards or upwards, whether such rivers ba nuvigable at presunt or bo rendered navigable in futue, as well as the navigation of any canals that may be built, shall be fros, so thas it s'all $\mathrm{n}$ ot be forbidden to any of the in'rabitants of the Polish provinees which are under the Russian or the Prussian Government.

"The same prinsiples establishod in favour of the subjects of the two High Conirasting Powers shall ba applied to the 
frequentation of the ports by the said subjects; it being understood that only such ports are here meant as can be reached by the navigation of the rivers and canals in question, or by that of the Haff giving access to Königsberg."

In order to facilitate navigation by the removal of obstacles, there is to be only one single navigation due calculated on tho capacity or tonnage of the vessel, or on the weight of the cargo (Art. 24). This due is to be fixed by commissaries of the two States. It is to be moderate, and its proceeds are to be used for preserving the navigability of the rivers. Each State will collest this due'within the limits of its territory.

It: is also agreed that, if either of the two Contracting Powers builds a new canal at its own expense, "the subjects of $\mathrm{His}$ Prussian Majesty shall never be subjected to navigation dues higher than those of H.M. the Emperor of all the Russias. There shall ba complete reciprocity in this respect."

Art. 25 abolishes for ever "all the burdensome dues of warehousing, breaking cargo, staple, lighter ('non-allege') and others of a similar kind, which might have existed contrary to the freedom of the navigation of the rivers and canals in question, throughout their whole extent."

Art. 29 declares transit trade free.

The same prinsiples, except the abolition of the dues enumerated in Art. 25, are to bo found in the treaty botwoen Austris and Russia, also made in Vienna on May 3rd, 1815, for the settlement of the affairs of Poland, and forming Annex I. of the Final Act of the Congress of Vienna.

310. Arrangements between Prussia and Russia.

In execution of these traaties, negotiations took place which led on December $7 / 19,1818$, to the signing of a treaty of commerce and navigation between the two Powers.

From Art. 1 (De Martens, Traités conclus par la Russie, VII., 331) we learn that this treaty applies to "the wholo territory which has bren part of Ancient Poland since 1772, and is comprisel between the Duna, the Dnieper, the Dniester, the Oder and the sea, Eastern Prussia being included." 
Art. 2 constitutes an attempt to comply with the provisions of Art. 22 of the Treaty of May 3rd, 1815 (supra). In order to ensure "an unlimited freedom of navigation" to their subjects the two Powers agreed on the following principles:

(a) The navigation shall not be interdieted to the subjects of either Power in the bays, any more than on the canals and: rivers as far as their mouth in the sea. The right even extends to such rivers as may in future be rendered navigable and to such canals as may be built.

(b) As corollaries to the right of navigation, the rights of towing and landing are recognised, and towing-paths are to be made.

(c) The police regulations, which may not impose any dues or charges, and are confined to ensuring the maintenance of the freedom, order, and security of navigation, shall be binding on the subjects of both nations.

(d) Mutual equality of dues and charges on navigation is provided for.

(e) The tariffs, once fixed, cannot be altered except by common consent. The same holds good of dues levied for the passage of bridges.

(f) The navigation of the Vistula is declared free from any due, except that levied in Prussia under the name of "SchiffsGefässgelder."

The other clauses of the treaty relate to liberty of commerce in general. We may, however, mention Art. 8 which abolishes "the dues which may have existed until now, contrary to the navigation of rivers and canals. . . ."

To this convention succeeded another, signed in Berlin on February 27th (March 11th), 1825 (Martens, Traités conclus par la Russie, VIII., p. 24, No. 308).

So far as navigation is concerned-

(a) it recalls that the dues for warehousing, breaking cargo, staple and other burdensome privileges of the same nature remain abolished and may not be revived;

(b) it confirms the rule of equal treatment of the subjects of both nations for the navigation of rivers and the use of towing-paths, locks, and canals; 
(c) it completely suppresses the levying of dues on the Vistula, the Niemen, and their tributaries $(d)$.

This convention remained in force until 1836. The commercial conventions which followed do not seem to have brought about any serious modifications of these principles.

\section{Arrangements between Russia and Austria.}

As to the arrangements between Russia and Austria, they are embodied in a Convention of August 5/17, 1818, earlier by a few months than that concluded with Prussia (Martens, Traités conclus par la Russie, IV., 61, No. 108).

The preamble recites that the two Powers, being determined "to give to the stipulations made by the Congress of Vienna .... the precision which this object imperiously requires" have decided:

(a) that the principle of free navigation and free frequentation of the ports, so far as it relates to provinces belonging! to the two Empires, applies to such rivers as "have their source in the territory of Ancient Poland (year 1772) and also to such rivers as traverse this territory, or communicate with it, and by means of canals, or by their confluence with other rivers, disembogue their waters into the sea" (Art. 1);

(b) the navigation as far as the sea and the frequentation of the ports "shall be free, so that they cannot be interdicted to any of the subjects of either of the High Contracting. Parties" (Art. 2);

(c) the same shall hold good of the existing canals or of those which may hereafter be built, and of all rivers navigable either now or in future, and "having their course between the eastern frontier of Ancient Poland, the Duna, the Dnieper, the Dniester and the Pruth" (Art. 3);

(d) steps shall be taken for the making and keeping in repair of towing-paths and landing-places (Arts. 4 and 5);

(e) the regulations of police and navigation shall be communicated to the respective consuls (Art. 6);

(d) We have seen that the preceding convention had already suppressed the dues on the Vistula, except one levied in Prussia. 
(f) from the point of view of navigation, the subjicts of either State "shall enjoy among their neighbours the rights appertaining to national traders" (Art. 7);

(g) equality of dues or charges on traffic by water is pirovided for (Art. 8).

To these general principles, we may add the two following articles:

Art. 9.- "As H.M. the Emperor of Austria does not levy any due whatever on the navigation of the rivers of Ancient Poland, and does not intend to impose any, H.M. the Emperor of all the Russias shall not levy dues on Austrian vessels on the Bug, except if these should pass through the canal of the Mouchawitza, or start from the banks of the Bug (Russian territory)."

Art. 10.- "The navigation of the Vistula, so far as its banks belong to the two High Contracting Parties, is declared free from any due."

This article is supplemented by the provision of Art. 2 (f) of the treaty signed a few months later between Russia and Prussia (supra).

Finally, there are several provisions calculated to facilitate transit.

The above treaty was revised in 1859 , but the revision did not affect the principles coneerning the fluvial navigation.

\section{(d) The Po.}

312. The Congress of Vienna and Preliminary steps.

Art. 96 of the Final Act of the Congress of Vienna (1815) contained the following provision: "The general principles adopted by the Congress of Vienna with regard to river navigation shall be applied to the Pô.

"Commissaries shall be appointed by the riparian States, at the latest within three months after the end of the Congress, in order to regulate everything connected with the execution of tho present article."

The Commission proceeded by stages. Thus on Oetober 16 th, 
1821, a convention was made between Austria and the Duchy of Parma concerning the navigation dues to be levied on the Pô and the sharing of their proceeds in common by the two States from September 1st, 1821 (Art. 1) '(Neumann, III., 650 ).

This convention in six articles was to determine after five years, by which time (end of April, 1826) it was hoped that the foundation for the general régime of the river would be laid. In consequence, on September 3rd, 1825, another convention (e) intervened, which renewed and completed that of 1821 (Neumann, IV., 116); but it was not until 1849 that a definitive solution was reached (Brit. and For. St. Pap., XXXVIII., p. 130).

\section{Definitive solution, 1849.}

On July 3rd, 1849, a convention was signed in Milan between Austria and the Duchies of Modena and Parma. It provided in Art. 1 that "the navigation of the Pô shall be free and exempt from any burden along the whole tract of the territorics of the signatory States as far as the Adriatic Sea, and it shall not be interdicted to, nor shall impediments be imposed in any way upon, any person whatever, with reservation of the regulations which may be now or hereafter determined with the cornmon consent of those States, and always in the sense most favourable to the development of the commerce of all nations.

"In like manner, the navigation of the streams joining the Pô, below the mouth of the Ticino, shall also be free, (1) if they are within the limits of any of the contracting States; (2) from the point where they leave the State in which they rise, as far as and including their confluence with the Pô, in which course, if there should exist any simple navigation dues, these shall not be greater for foreigners than for natives."

Art. 2 suppressed duties of transit, compulsory landing, loading and unloading, \&c., with the exception of sanitation dues,

(e) Art. 1 and preamble confirm equal participation in the proceeds. drt. 3 and foll. relate to the formalitios for farming out the dues on navigation. 
port dues for vessels which come from or return to the sea, dues for passing bridges, weighing and warehousing duties, \&c.

According to Art. 3, no vessel on the Pô shall be compelled to put in, or stop in places other than those to which it is bound.

Art. 4 abolished monopolies of navigation:

A mixed Commission, whose president was appointed by Austria, was entrusted with supervising the execution of the convention, the preservation of the navigability, the keeping of the towing-paths in good repair, and with keeping up the necessary relations between the contracting States.

This Commission, which was to assemble twice a year, had among its duties to supervise the officials collecting the navigation dues and to remove all abuses.

The preamble of this convention recited: "Having with full accord agread through their respective Governments to promote for the benefit of commerce the free navigation of the Pô, at present from the confluence of the Ticino to the Adriatic, and H.M. (the Emperor of Austria) accordingly reserving to himself to obtain also the assent of the Pontifical State, [the High Contracting Parties] have in the meantime determined as follows; - though they shall not act upon such determination until the above mentioned assent shall be obtained ...."

The accession of the Holy See was signed in Rome on February 12th, 1850 (St. Pap., XXXVIII., 136).

\section{No longer an international River.}

The peace of Zurich, on November 10th, 1859, confirmed the maintenance of the régime thus established which lasted until 1866 , at which time the $\mathrm{Po}$ ceased to be an international river. However, although it passed entirely within Italian jurisdiction, it nevertheless remained accessible to foreign vessels.

\section{B. Spanish and Portuguese Rivers.}

(a) The Douro.

315. By a Convention of August 31st, 1835, between Spain and Portugal (N. R., XIV., 97) the navigation of the Douro 
was declared free for the subjects of the two contracting parties. Art. 1 stipulates equality of treatment throughout the whole navigable course of the river. The two States shall carry out, within their respective territories, the necessary repairs, and undertake to improve, as much as possible, the condition (régime) of the river in the interest of navigation (Art. 2). Art. 3 provides for the uniformity of the tariffs and of the regulations for the fluvial police. A "mixed" Commission consisting of two Portuguese and two Spanish delegates is entrusted with this work of unification (Art. 4). The two States undertake to impose no dues, under any name whatsoever, except those fixed by the mixed Commission, and the rate of such dues can only be modified by common consent (Art. 6). No monopoly for the carriage of goods or of passengers can be created on the river (Art. 7). Art. 8 relates to the erection of a storehouse at Oporto, and Art. 10 reserves the independence of the two States in matters relative to customs.

The mixed Commission mentioned in Art. 4 promptly set to work. On April 14th, 1836, tariffs and regulations were published. They were revised by a convention of May 23rd, 1840. By this latter agreement each country reserves the small coasting trade (cabotage) in the parts of the river of which it possesses both banks. Each State also reserves for itself the free disposition of the proceeds of the transit dues which it has levied, while the navigation dues and fines inflieted for infractions of the police regulations are to be used for keeping the river in good repair.

The three following articles are of special interest:

Art. 11.- "The navigation of the Douro from Portugal to Spain and vice vers $\hat{a}$ is reserved to the subjects of the two countries without distinction; Portuguese vessels in Spain and Spanish vessels in Portugal shall be deemed national (seront considérés comme nationales).... ."

Art. 12.- "If unhappily . . . war should break out between the two countries, there shall be no embargo on, or confiscation of, the vessels, or of stored goods or of goods carried by the river; the buildings destined to the use of navigation and the collection of dues shall also be respected.

All persons 
in the service of the mavigation shall also be religiously respected, as shall also all individual property found in the case foreseen by this article."

Art. 13.- "In case of plague, each State shall [be free to.] adopt such measures as shall best conduce to its security, while taking care not to interfere with trade any more than necessary (en ayant soin que le commerce en souffre le moins possible)."

Finally; we may mention the obligation for any master or boatman to have a patent.

\section{(b) The 'Tagus.}

316. The treaty concluded in Lisbon on August 31st, 1829, between Ferdinand VII. of Spain and Don Miguel, the King of Portugal, may be mentioned.

The two sovereigns decided that "the river Tagus should be frec to their respective subjects from Aranjuez to the ocean, and vice versâ" ; they agreed that eaeh, within their respective jurisdiction, should grant to the subjects of the other State the same treatment as to their nationals, both with regard to the collection of dues and to the regulations of fluvial police. The tariffs should be fixed by common consent and the dues collected separately by each State within its territory.

The customs were declared independent.

Finally, an additional elause extended to the Douro the benefit of the above clauses, and reserved the making of others, if it were thought fit. But this treaty was not recognised by the Government of the Queen Donna Maria II.

\section{Addenda to the régime of the Danube.}

(a) The Pruth.

317. Without entering into the details of former conventions, it is interesting to pay some attention to the convention relative to the navigation of the Pruth, signed in Bucharest on December 3/15, 1866, between Austria, Russia and the united principalities of Moldavia and Wallachia (which have become the Kingdom of Rumania).

This convention provides that "the navigation of the Pruth, 
throughout its whole extent in so far as it traverses or separates the States of the High Contracting Parties, shall be entirely. free and shall not, with regard to commerce, be forbidden to any flag ...." (Art. 1).

A reasonable change ("d'un taux convenable") is imposed with the exclusive object of covering the expense of preserving the navigability of the river. No other dues shall be levied, except what the riparian "communes" may collect for the use of conveniences which they have erected at their own expense (Arts. 2 and 18). Such dues shall only be collexted from vessels which avail themselves of the said works, and they must be approved by the mixed Commission.

This mixed Commission, which in Art. 7 of the convention is called "une autorité internationale," decides what works of improvement must be undertaken, fixes the tariffs, draws up tho police regulations, and supervises the repairs of the fluvial works.

Art. 3 declares merchandise carried by the river free from any passage or transit duty, and Art. 4 provides that the "customs boundaries shall everywhere follow the river banks without ever crossing them." Hence it follows that a vessel is subject to inspection by the officers of the customs only when landing.

Some parts of this Convention of 1866 were modified on $18 / 2$ March, 1895; but all the provisions above mentioned remained unaffected.

Among the new clauses, we may mention one which provides that "the works for the improvement ("correction') of the Pruth shall be executed according to a general plan ("projet') for the whole of its navigable course" (Art. 11).

The regulation of navigation and police of 1/13 April, 1896, drawn up in consequence of the new convention, confirms that "the navigation of the Pruth shall be entirely free and shall not, with regard to commerce, be interdicted to any flag."

A licence is required for navigating a vessel. This licence is delivered to the subjects of the riparian States by their respective national authorities, and to foreigners by the Inspector of the Navigation of the Pruth. 
The navigation of the river is forbidden to ships of moro than 300 tons (burden).

Finally, Art. 68 of the Regulation provides: "The Agents who collect the dues and the Inspector of the Navigation of the Pruth are clothed with an international character; and their sphere of action extends to all flags without distinction.'

\section{(b) An Austro-Serbian Convention.}

318. On the 10/22 February, 1882, a convention was signed at Belgrade by Austria and Serbia mutually, ensuring to the subjects of both nations, with regard to the transport of merchandise and passengers by the natural or artificial navigable waterways of the two countries, the same rights, advantages and exemptions as are conoeded to the nationals and to thi subjects of the most favoured nation.

Both States engage not to establish any "exclusive privilege of navigation or compulsory duty such as staple, breaking cargo. pre-emption ("premier achat') and others of the same nature," on the navigable waterways forming the Austro-Serbian boundary.

Nor is any "toll based only on the fact of navigation or any duty on merchandise on board a ship" to be imposed. There is, however, one exception in favour of the dues on the Danube for the passage of the cataracts between Moldava and TurnSeverin "when the works destined to remove the obstacles in the way of navigation shall have been executed." 


\section{APPENDIX II.}

\section{$\longrightarrow$ \\ NOTES ON AMERICAN RIVERS.}

(a) The Mississippi.

319. At the end of the eighteenth century, the Spaniards, established at the mouth of the river, alleged an exclusive right of navigation on the part of the river subject to their jurisdiction. The populations settled near the banks of the upper river were in consequence deprived of access to the sea. The United States protested.

The conflict which thus arose presented some analogy with that which took place between Joseph II. and Holland with regard to the closing of the Scheldt; yet there was this difference that, while the Dutch based their right on the Treaty of Münster (1648), the Spaniards obstructed the Mississippi in the belief that in so doing they were only exercising an incontestable right of theirs, as the masters of the mouth of the river. The claim of the Spaniards was all the more vexatious because they occupied only a relatively small and sparsely peopled territory, while the territories which they deprived of access to the sea were immense and well-peopled. From the economic point of view, they obviously acted against their own interest; but they did not look at the question in that light;, and they blindly persisted in maintaining a measure which they alleged they were justified in taking in virtue of their right of sovereignty.

The protest of the United States, on the other hand', was based on former treaties $(a)$, and the law of nature and of nations.

(a) The United States set up the treaty of peace signed in Paris in 1763 by Great Britain, France and Spain; it stipulated the cession of Canadi 
"Tho ocean," said Mr. Jefferson, "is free to all men, and their rivers to all their inhabitants. . . ."

And he went on: "Accordingly, in all tracts of country united under the same political society we find this natural right universally acknowledged and protected by laying the navigable rivers open to all their inhabitants. When their rivers enter the limits of another society, if the right of the upper inhabitants to descend the stream is in any casa obstructed, it is an ast of force by a stronger society against a weaker, condemned by the judgment of mankind (American St. Pap., For. Relat., I., 253-4).

In the end, Spain understood the impossibility of maintaining her pretensions, and an arrangement was arrived at in 1795 (October 27th) by the Treaty of San Lorenzo el Real (St. Pap., VIII., 540). In 1819 the Mississippi passed entirely under the jurisdiction of the United States (Treaty of February 22nd, 1819, signed at Washington by the United States and Spain) (c).

\section{(b) The St. Lawrence and the Great Lakes.}

\section{American contention.}

As it did earlier with regard to the Mississippi, the controversy arose here in 1824 by the aceess to the sea being barred, this time, by Great Britain.

The United States appealed to the law of nature, necessity and the decisions of the Congress of Vienna (1815). The argument of Mr. Adams has been summarised as follows:

"The United States was bound to maintain for the proplo of the territory of Michigan and of the States of Illinois, Indiana, Ohio, Pennsylvania, New York and Vermont 'the natural right of communicating with the ocean, by the only

and Florida, and granted to British subjests the right of navigation on the Mississippi as far as the sea. They also referred to a treaty with Great Britain resoseding Florila to Spain.

(b) This declaraiion, niade on Mareh 18th, 1792, preceled by a few months the de ree of the "Executive Council" of the French Republic opening the Sheid' and the Neuse to navigation (Nov. 16th, 1792).

(c) St. Pap., VIII., p. 524. 
outlet provided by nature, from the waters bordering upon their shores.' He admitted that the possession of both the shores of the river and its mouth had been held to give the right of obstructing and interdicting its navigation to the people of other nations inhabiting the upper banks; but he maintained that, while the exclusive right of 'jurisdiction" over a river originated in the 'social compact' and was 'a right of sovereignty,' the right of navigating the river was 'a right of nature, preceding it in point of time, and which the sovereign right of one nation cannot annihilate as bolonging to the people of another' $(d)$. In support of this viow, he invoked the Acts of the Congress of Vienna, declaring the navigation of various rivers to bo 'free to all nations" " (Amer. St. Pap., For. Relat., VI., 757-8).

As in the case of the Mississippi, the United States appealed to the Treaty of Paris of 1763 , and pointed out that the opening of the river to navigation could cause no prejudice to British interests.

\section{British CONTENTION.}

The reply of the British plenipotentiary to the American argument (St. Pap., XIX., 1075) is very long. We must. be content with referring only to the more important passages. "... The United States pretend to no less than the perpetual enjoyment of a fros, uninterrupted passage, indeFendent of the territorial sovereign, through a large and very important part of the British possession in North America. . . .

". . . There will, however, bo littla difficulty in showing that tine claim asserted by the American plenipotentiary does not rest, as to any foundation of natural right, on a correct application of the authorities which he has consulted. . . .

"... The right of navigating this river, says the American plenipotentiary, is a right of nature, pre-existent in point of time, not nocessary to have beon surrendered up for any purpose of common good, and unsusceptible of annihilation." The right here doseribed can be no other than of that. 
kind which is generally designated in the law of nations a perfect right. Now, a perfect right is that which exists independent of treaty; which necessarily arises from the law of nature; which is common, or may, under similar circumstances, be common to all independent nations; and can never be denied or infringed by any State without a breach of the law of nations. Such is the right to navigate the ocean without molestation in time of peace.

"Upon these principles, now universally reoeived, it is contended for the United States, that a nation possessing both shores of a navigable river at its mouth, has no right to refuse the passage of it to another possessing part of its upper bank and standing in need of it as a convenient channel of commercial communication with the sea. Applying the same principles to the case of the St. Lawrence, the American Government maintain that Great Britain would bo no more justified in controlling American navigation on that river than in assuming to itself a similar right of interference on the high seas.

"To this extent must the assumption of a perfect right ba carried, or such claim is no longer to be considered in that character; but falling under the denomination of an imprerfect right, it becomos subject to considerations essentially and entirely different. . . ."

On an inquiry into the existence of the right described above, the Note then concludes that it is "at bast, only an imperfect right." Then, arguing that the "imperfect right" claimed by the United States is admitted by the authorities appealed to, only as "an occasional liberty of passage, not of that perpetuai uninterrupted kind, which the regular activity of modern eommerce requires," the British Note points out that, if the Congress of Vienna had intended to recognise a natural right, it would have proclaimed it clearly. But it was not without reason that the Powers preferred the foundation of the mutual consent of nations, without imposing any obligation, except in some special cases, such as that of the Scheldt. In fact, no nation does exercise the right of navigating through the territory of another nation without express treaty stipulations. Lastly, while claiming the right to protect hor sovereignty, 
Great Britain conceded that the United States might have an interest in obtaining the opening of the river, though they could not exact it as a right.

\section{AMERICAN REPLY.}

We now turn to the American reply (June 19th, 18:6).

". . . What is the right claimed by the United States? The North American lakes are among the largest inland seas known on the globe. . . These Great Lakes are united by but one natural outlet to the ocean, the navigation of which is common to all mankind. . . The United States do not claim a right of entry into British ports, situated on the St. Lawrence, against British will, and to force their productions into the consumption of British subjects. They claim only the right of passing these ports and transporting their productions to foreign markets, or to their own, open and willing to reacive them; and as incident and necessary to the enjoyment of that right, they claim the privilege of stoppage and transhipment, at such places within the British jurisdiction, and under such reasonable and equitable regulations as may be prescribed or agreed upon."

Maybe, it was pointed out, every nation has, like China, the right to prevent the passage of merchandise. "But, if an innocent passage is demanded for purposes unconnected with the commerce or society of the State through which it is required, it cannot justly be denied. In the enjoyment of this right of passage, the use of the territories in which it is exerted, is merely collateral."

If the Congress of Vienna has confined itself to regulating the use of a right, does it follow that the right is merely conventional and not a natural one? Natural rights must sometimes be the object of regulations.

The United States declare themselves ready to aceept tho principle of reciprocity. If the boundary river Columbia is found to be navigable, the United States are ready to recognise the right of British subjects to navigate on it as far as the sea. If new explorations lead to the discovery of possibilities of 
passage along the Mississippi for Canadians, this passage shall not be contested.

Finally, perceiving that each party will stick to its reasons, the United States prefer to give up the discussion and arrive at some practical arrangement. Great Britain, as well as the United States, has an interest in making sueh an arrangement. But there can be no question, on the part of Great Britain, of claiming territorial concessions in exchange for the right of navigation. "Nor can this Government agree to barter away any portion of the territorial sovereignty of Maine, or the proprietary rights of the Commonwealth of Massachusetts, for the navigation of a river in which neither of them has any direct interest. If the question of the navigation of the St. Lawrence could be accommodated in a manner satisfactory to both parties, so as to let, the citizens of the United States into tha practical and benefieial enjoyment of it, their Government would be willing that the arrangement should be equally silent in regard to the admission on the one side, or the abandonment on the other, of the RIGHT, as claimed and denied by the parties respectively."

On August 8th, 1826, the United States sent a new Note, insisting on an amicable settlement of the question, but again declaring that they eould not adhere "to any treaty by which they should renounce that right [of free navigation], expressly or by implication.

\section{A PRACTICAL CONCESSION.}

On September 21st, 1827, Great Britain again refused to recognise any right whatever: "The British plenipotentiary will not entertain any proposition respecting the navigation of the St. Lawrenee, founded on the right elaimed by the United States to navigate that river to the sea." But at the same timo, the British Cabinet represented to the United States Minister in London that this refusal did not preclude an arrangement on other bases. The representative of the United States wrote to Washington, on Oetober 21st, 1827: "Upon the whole, I have greai hopes that, setting aside the abstraet notion of right, and though no arrangement by treaty should take place, our 
citizens will, ere long, and through the acts of Great Britain alone, enjoy all the benefits of the navigation which they could obtain, even if the right were recognised. Should this expectation bo disappointed, it is probable that a sufficient remedy will be found in the power to retaliate above St. Regis."

\section{The Treaty of 1854.}

It was not until 1854 that a solution was reached in the form of a treaty relative to fisheries, commerce and navigation, signed at Washington, June 5th, 1854.

The preamble explained the object of the treaty as follows: "to avoid further misunderstanding ... . in regard to the extent of the right of fishing on the coasts of Britannic North America . . . . and being also desirous to regulate the commerce and navigation between their respective territories and people... . in such manner as to render the same reciprocally beneficial and satisfactory. . . ."

Art. 4 gives the bases of the arrangement arrived at with regard to the navigation of the St. Lawrence:

"It is agreed that the citizens and inhabitants of the United States shall have the right to navigate the river St. Lawrence and the canals in Canada, used as the means of communicating between the Great Lakes and the Atlantic ocean, with their ressels, boats and crafts, as fully and freely as the subjects of His Britannic Majesty, subject only to the same tolls and other assessments as now are or may hereafter be exacted of H.M.'s said subjects; it being understood, however, that the British (iovernment retains the right of suspending this privilege, on giving due notice thereof to the Government of the United States.

"It is further agreed that, if at any time the British Government should exercise the said reserved right, the Government of the United States shall have the right of suspending, if it think fit, the operation of Art. 3 of the present treaty $(d)$ in so far as the province of Canada is affected thereby, for as long as the suspension of the free navigation of the river St. Lawrence or the canals may continue.

(d) Reciprocal admission of merchandise free from duty. 
"It is further agreed, that British subjects shall have the light freely to navigate Lake Michigan with their vessels, boats and crafts, so long as the privilege of navigating the river St. Lawrence secured to American citizens by the above clause of the present article shall continue; and the Government of the United States further engages to urge upon the State Governments to secure to the subjects of Her Britannic Majesty the use of the several State canals on terms of equality with the inhabitants of the United States.

"And it is further agreed that no export duty or other duty shall be levied on lumber timber of any kind, cut on that portion of the American territory in the State of Maine watered by the river St. John and its tributaries, and floated down that river to the sea, when the same is shipped to the United States from the province of New Brunswick."

As clearly appears from this article, no more than a temporary concession, revocable on giving due notice, was obtained. It was abandoned by the United States itself in 1866 .

325. The Treaty of 1871.

However, new negotiations were then begun by the United States which persisted in claiming access to the seas as a right, while Great Britain refused to look upon the question in that light. These negotiations led to the Treaty of Washington of May 8th, 1871.

Art. 26.- "The navigation of the river St. Lawrence, ascending and descending from the forty-fifth parallel of north latitude, where it ceases to form the boundary between the two countries, from, to, and into the sea, shall forever remain free and open for the purposes of commerce to the citizens of the United States, subject to any laws and regulations of Great, Britain, or the Dominion of Canada, not inoonsistent with sucli privilege of free navigation.

"The navigation of the rivers Yukon, Porcupine and Stikine, ascending and descending, from, to, and into the sea, shall forever remain free and open for the purposes of commerce to the subjects of Her Britannic Majesty and to citizens of the United States, subject to any laws and regulations of either 
country within its own territory, not inconsistent with such privilege of free navigation.

Art. 27.- "The Gorernment of Her Britannic Majesty engages to urge upon the (xorcrmment of the I)ominion of Canada to secure to the citizens of the United States the use of the Welland. St. Lawrence, and other canals in the Dominion; and the Government of the United States engages that the subjects of Her Britannic Majesty shall enjoy the use of the St. Clair Flats canal on terms of equality with the inhabitants of the United States, and further engages to urge upon the State Governments to secure to the subjects of Her Britannic Majesty the use of the several State canals connected with the navigation of the lakes or rivers traversed by, or contiguous to, the boundary line between the possessions of the High Contracting Parties, on terms of equality with the inhabitants of the United States.

Art. 28.-" The narigation of Lake Michigan shall alson . . . be free and open for the purpose of eommerce to the subjects of Her Britannic Majesty, subject to any law and regulations of the United States or of the States bordering thereon, not inconsistent with such privilege of free navigation."

\section{(c) The Amazon and its Tributaries.}

326. On October 23rd, 185̃1, the Emperor of Brazil signed at Lima with the Republic of Peru a convention by which the two contracting parties, "equally animated by the desire of facilitating commerce and river navigation by their mutual frontier and rivers," decided to adjust " the principles and mode of making a trial, by which it may better be ascertained upon what bases and conditions that commerce and navigation shall hereafter be stipulated for" (St. Pap., 42, 1308).

The question was above all to promoto the navigation by steam vessels of the river Amazon and its confluents and thus to help to increase the traffic and the rate of population in very backward regions. It was agreed that "such merchandise, produce, and ressels as may pass from Brazil to Peru and from Peru to Brazil by the joint frontier and rivers, shall be freo 
from any duty, impost or tax whatsoever, from which the same descriptions of produce are free in their own territories, with which they are in every respect to be placed on an equal footing" (Art. 1).

By the next article, it was agreed that in case a steam navigation company should organise a service from the mouth of the Amazon to the Peruvian territory, the two contracting parties should grant it an annual subvention.

This convention, which was in fact the prelude to the carrying out by Brazil of a project aiming at the establishment to her own benefit of a kind of monopoly of steam navigation on the Amazon, was limited to six years' duration, although it might be renewed.

While Brazil was thus eanvassing the other riparian States, the United States of America, which looked unfavourably upon such a policy, entered a protest. But Brazil energetically: upheld her right to forbid access to the river to foreign vessels, notably to those of the United States. "The great argument; used," said Eug. Sichuyler (e), was that "the navigation of the Amazon belonged of right exelusively to the nations owning its banks," and in support of this, it was constantly brought up "that if citizens of the United States were allowed once to astablish themselves, either for purposes of trade or abode, in the interior of South America, they would inevitably introduce their own institutions and renounce the allegiance of their adopted country" $(f)$.

Great Britain and France joined their protests to those of the United States, which succeeded in dealing separately with some of the riparian States; but Brazil persisted in her policy. Then the United States had recourse to threats. We read in the instructions given on August 8th, 1853, to the United States Minister at Rio de Janeiro: "Should you discover any reluctance on the part of the Government of Brazil to yield to this just claim, you will impress upon it the determination of the United States to secure it for their eitizens. The President

(e) Americun Diplomacy aul the furtherance of Commeree, VI.

(f) There was an idea prevalent at that time throughout South Imeries that the. United States wero bent on annexation. 
is desirous to cultivate the most amicablo relations with that. Government, and would much regret to have these relations disturbed by its persistence in a poliey so much at varianex with all the liberal views of civilised and enterprising nations."

A few months later, in December, President Pierce, in his annual message, expressed himself as follows, with regard to the oonflict: "Considering the vast regions of this Continent. and the number of States which would be made accessible by the free navigation of the river Amazon, particular attention has beer. given to this subject. Brazil, through whose territories it passes into the ocean, has hitherto persisted in a policy so restrictive in regard to the use of the river as to obstruet. and nearly exclude foreign commercial intercourse with tho States which lie upon its tributaries and upper branches. Our minister to that country is instructed to obtain a relaxation of that policy, and to use his efforts to induee the Brazilian Government to open to common use, under proper safeguards, this great natural highway for intrernational trade. Several of the South Ameriean States are deeply interested in this attempt to secure the free navigation of the Amazon, and it is reasonable to expect their co-operation in the measure. As the advantages of free commercial intercourse among nations are better understood, more liberal views are generally entertained as to the common rights of all to the free use of those means which nature has provided for international communication. Te these more liberal and enlightened views it is hoped that Brazil will conform her policy, and remove all unnecessary restrictions upon the free use of a river which traverses so many States and so large a part of the Continent."

Thirteen years elapsed b fore this hope was realised.

In 1859 (May 5th), we see Brazil signing at Caracas a treatr with Venezuela, stipulating that Brazilian vessels shall be free to pass from Brazil to Venezuela along the Rio Negra or Guainia, the Casiquiare and the Orinoco. By reciprocity, Brazil authorises Venezuelian vessels to pass along the Rio Negro and Guainia and Amazon and go out into the ocean and vice versâ. But the coasting trade is forbidden (Art. 8). The contracting parties, besides, engage to seek the means of unifying the river police in their respective jurisdietions and, 
as far as possible, the tariffs of navigation dues (Art..11). (St. Pap., L., 1164).

There: was here an abatement in Brazil's rigorous policy. It is true that, in consideration for this concession to Venezuela; Brazil obtained, by the Orinoco, one more access to the sea.

A little later, a more decided step took place in the way pointed out by President Pierce in 1853.

On December 7th, 1866 (St. Pap., 58, 551), "with a view to promoting the aggrandizement of the Empire, facilitating its international intercourse more and more, and imparting animation to the navigation and commerce of its river Amazon and its confluents Tocantins and San Francisco" the Brazilian Government decreed:

By Art. 1, the opening to the vessels of all nations, as from September 7 th, 1867, of the navigation of the river Amazon as far as the frontiers of Brazil; of the river Tocantins, as far as Cametá; of the Tapazoz, as far as Santarem; of the Madeira, as far as Borda; and of the river Negro, as far as Manáos.

By Art. 2, the opening of the navigation of the river San. Francisco, as far as the city of Penedo, on the same date.

By Art. 3 that: "In those confluents of the river Amazon, and in the parts of same where only one bank belongs to Brazil, the navigation, as far as concerns their respective limits and police regulations, will depend on previous arrangements with the boundary States.'

Lastly: there was a clause maintaining in force the two conventions above quoted with Peru and Venezuela.

On July 31st of the next year (1867), the Brazilian Government published its new regulation of navigation. It began as follows: "The navigation, from September 7th, 1867, forward, shall be open to merchant vessels of all nations. . . ."

(d) The River Plate and its Tributaries.

327. Dealings between riparians.

On May 24th, 1851, the Government of Monte-Video, Uruguay, decided by decree the following, concerning the navigation of the tributaries of the river Plate: 
I. "The coasting vessels bearing the flags of the provinces that border on the Uruguay, Paraná and Paraguay shall be considered in the port of Monte-Video on the same footing with regard to their privileges as national coasting vessels."

II. "This resolution shall be observed at present, but without limitation and without prejudice to the demand at the proper time for suitable reciprocity" (St. Pap., XLII., 1315).

On October 12th of the same year, the same Government, dealing with Brazil, adhered to the following clauses:

"Both the High Contracting Parties being desirous to bind more closely their friendly relations and to encourage their respective commerce, have agreed on the principle of declaring. the navigation of the Uruguay and that of the affluents of that river. which belong to them, common to both" (Art. 14).

"Both the High Contracting Parties oblige themselves to invite the other States bordering on the river Plate and its affluents, to enter into a similar convention with the object of making the navigation of the rivers Paraná and Uruguay free for the said bordering States" (Art. 15).

Art. 16 provided that in case of agreement there would be occasion for the establishment of a uniform river police and of uniform tariffs for navigation dues.

By Art. 17, in case of disagreement, Brazil and Uruguay. were to come to an understanding between themselves concerning the navigation of the Uruguay and its tributaries.

Finally, it was decided: (1) that the Isle of Martin Gareia. should never be allowed to become the property of any riparian State which had not adhered to the principle of free navigationfor this island might serve as a basis for the prevention of navigation on the tributaries of the river Plate.

(2) To undertake, in the common interest, works either for the destruction of the rocks hindering the navigation of the Uruguay and of the Salto Grande, or in order to obviate these obstacles by means of a lateral canal-the expense of such works to be covered by a special due levied on vessels profiting: by them. 
328. ADMISsION OF ALL FlaGs.

After having eonsidered the river Plate as closed to nonriparian vessels and interesting the riparian States only within the limits of their respective jurisdictions, the Argentine Confederation understood that it was to her own interest to adopt a more liberal poliey.

On Oetober 3rd, 1852 (St. Pap., XLII., 1313), the provisional director of the Argentine Confederation, General Urquiza, signed at Parana a decree providing that:

I. "The navigation of the rivers Paraná and Uruguay is permitted to all merchant vessels, whatever may be their nationality, their tonnage, or the place from whence they come."

II. "Every merehant vessel may enter the qualified ports in the rivers Paraná and Uruguay."

A fortnight later, on October 18th, 1852, a statute of the provines of Bucuos Ayres provided that:

"The province of Buenos-Ayres reeognises the opening of the river Parana to the commeree and mereantile navigation of all nations as a principle of general eonvenienee, and on its part declares and grants the same heneeforth" (State Pap., XIII., 1314).

The next year, a more decisive step was taken. I treaty was concluded on July 10th, 1853, at San José de Florès, between the Argentine Confederation and Great Britain. France and the United States of Ameriea. This is its eompletr. text (St. Pap., XLII., 3):

Art. 1.- "The Argentine Confederation, in the exercise of her screreign rights, coneedes ('permet') the free navigation of the rivers Parana and Uruguay, wherever they may belong to her, to the merehant ressels of all nations, subject. only to the eonditions which this Treaty establishes, and to the regulations sanctioned, or which may hereafter be sanctioned. by the national authority of the Confedieration."

Art. 2.- "Consequently, the said vessels shall be adnitted to remain, load, and unload in the places and ports of the Argentine Confederation which are open for that purpose."

Art. 3.- "The Gorernment of the Argentine Confederation, 
being dowirous to provide every facility for interior navigation, agrees to maintain beacons and marks pointing out the channels."

Art. 4.- "A uniform system shall be established by the competent authorities of the Confederation for the colloction of the customs duties, harbour. lights, police and pilotage dues, along the whole counse of the watres which belong to the Confederation."

Art. 5.- "The High Contracting Parties, considering that the Island of Martin Garcia may, from its position, embarrass and impede the free navigation of the confluents of the river Plate, agree to use their influence to prevent the possession of the said island from being retained or held by any State of the river Plate, or its confluents, which shall not have given its adhesion to the principle of their free navigation.'

Art. 6.- "If it should happen (which (rod forbid) that war should break out between any of the States, Republies, or Provinces of the river Plate or its confluents, the navigation of the rivers Parana and Uruguay shall remain free to the merchant flags of all nations, excepting only the traftie of munitions of war, such as arms of all kinds, gumpowder, lead and cannon-balls.",

Art. 7.- "Power is expressly reserved to His Majesty the Emperor of Brazil, and the Governments of Bolivia, Paraguay and the Eastem State of Uruguay, to become parties to the present Treaty, in case they should be disposed to apply its principles to the parts of the rivers Parani, Paraguay, and Uruguay, over which they may respectively possess fluvial rights."

Art. 8.- "The principal objects, for which the rivers Paraná and Uruguay are declared froe to the commerce of the wiorld, being to extend the mercantile relations of the eountries which border on them, and to promote immigration, it is hereby agreed that no favour or immunity shall be granted to the flag or trade of any other nation, which shall not equally extend to those of Her Britannie Majesty" (or of France, or of the United States of America). 
In fact, the adhosion of the riparian. States had boen given: Already on March 4th, 1853, by a treaty signed at Assumption, the Republie of Paraguay had conceded to Great Britain; under the condition of reciprocity, "the free navigation of the river Paraguay as far as Assumpition, the capital of the Republic, and of the right side of the Paraná from where it belongs to her as far as the city of Encarnacion". (St. Pap. XLII., 19).

This concession, also granted to France, was extended to the United States by a treaty concluded at Assumption on Feb. 4th, 1859 .

On October 10th, 1853, the Republic of Uruguay opened, by decree, its waterways to the commerce of all nations.

Or Nor. 20th, 1857, in a convention with Brazil, the Argentine Republic, generalizing the principles of the Treaty of July 10th, 1853, declared that the Uruguay, the Parana and the Paraguay, from their confluence with the river Plate to the interior ports open or to be opened by the riparian States, should henceforth be freely accessible to the commerce and navigation of all nations. This freedom, however, did not, in the absence of a special convention, extend to the tributaries of these rivers or include coasting navigation ("cabotage"). The warships of the riparian States were to be free to navigate throughout the whole extent of the rivers accessible to the mercantile marine.

The next year (1858), Bolivia opened to the United States the river Plate and its tributaries, and invited to its ports the vessels of all nations.

(e) The Rio Graxde.

329. The treaty of February 2, 1848, signed at Guadalupe Hidalgo, between the United States of America and Mexico (St. Pap., XXXVI1., 567) contains the following clauses with regard to navigation: "The vessels and citizens of the United States shall, at all times, have a free and uninterrupted passage by the Gulf of California, and by the river Colorado below its confluence with the Gila, to and from their possessions situated 
north of the boundary line . . . ; it being understood that this passage is to be by navigating the Gulf of California and the river Colorado, and not by land, without the express consent of the Mexican Government.

"If, by the examinations which may be made, it should bo ascertained to be practicable and advantageous to construct a road, canal, or railway, which should in whole or in part run upon the river Gila, or upon its right or its left bank, within the space of one marine league from either margin of the river, the Governments of both Republics will form an agreement regarding its construction, in order that it may servo equally for the use and advantage of both countries" (Art.6).

"The river Gila, and the part of the Rio Bravo del Norte (i.e., the Rio Grande) lying below the southern boundary of New Mexico, being . . . divided in the middle between the two Republics, the navigation of the Gila and of the Bravo below the said boundary shall be free and common to the vessels and citizens of both countries; and neither shall, without the consent of the other, construct any work that may impede or interrupt, in whole or in part, the exercise of this right; not even for the purpose of favouring new mothods of navigation. Nor shall any tax or contribution, under any denomination or title, be levied upon vessels, or persons navigating the same, or upon merchandise or effects transported thereon, except in the case of landing upon one of their shores. If, for the purpose of making the said rivers navigable, or for maintaining them in such state, it should be necessary or advantageous to establish any tax or contribution, this shall not be done without the consent of both Governments.

"The stipulations contained in the present article shall not impair the territorial rights of either Republic within its astablished limits" (Art. 7).

On December 30th, 1853, a treaty signed in Mexico modified, on account of changes in the boundaries of the two Republics, certain parts of Arts. 6 and 7 above quoted, but did not alter any of the clauses relative to navigation (St. Pap. XLII., 724). 


\section{APPENDIX III.}

\section{$\longrightarrow$ \\ NOTES ON AFRICAN RIVERS.}

(a) Freedom of Navigation in the Free Trade Zone.

330. It has been pointed out. ( $\$ 192$, esp. note) that the: principle of free navigation was looked upon by the Conference of Berlin as an essential adjunct of commercial freedom. This accounts for the existence of Art. 2 in the Declaration relative to freedom of commerce. It provides that:

"All flags, without distinction of nationality, shall have free access to the whole of the coastline of the territories above enumerated, to the rivers there rumning into the sea, to all the waters of the Congo and its affluents, including the lakes, and to all the ports situate on the banks of those waters, as well as to all canals which may in future be constructed with the view of connecting with one another the watercourses or lakes within the entire area of the territories described in Art. 1. Those trading under sueh flags may engage in all sorts of transport and carry on the coasting trade by sea and rixer, as well as boat traffic, on the same footing as if they were subjects."

Although it had been understood that the Conference was to confine its labours, with regard to free navigation, to tho Congo and Niger, the limits indicated in Art. 1 comprise, besides the territories forming the basin of the Congo and its affluents $(a)$ :

(a) The basin of the Congo is defined as follows: "The basin is bounded by the watersheds (or $m$ untain ridges) of the adjarent basins, namely, in partieular, those of the Niari, the Ogowe, the Sehari, and the Nile, on the North; by the eastern watershed line of the affluents of Lake Tanganyika on the East; and by the watersheds of the basins of the Zambesi and the Logé on the South. It therefore comprises all the regions watered by the Congo and its affluents. including Lake Tanganyika, with its eastern tributaries." 
(a) The maritime zone extending along the Atlantic Ocean from the parallel situated in $2^{\circ} 30^{\prime}$ of south latitude to the mouth of the Logé; - the northern boundary following the parallel situated in $2^{\circ} 30^{\prime}$ from the coast to the point where it mets the geographical basin of the Conga, aroiding the basin of the Ogowé, to which the provisions of the Act do not apply; - the southern boundary following the course of the Loge to its source, and thence passing eastwards till it joins the goographical basin of the Congo.

(b) The zone stretching eastwards from the Congo basin to the Indian Ocean from 5 degrees of north latitude to the mouth of the Zambesi in the south, from which point the line of demarcation will ascend the Zambresi to 5 miles above its confluence with the Shiré, and then follow the watershed betwoen the affluents of Lake Nyassa and those of the Zambesi, till at last it reaches the watershed between the waters of the Zambesi and the Congo.

It is, however, necessary to bear in mind the reservations which accompany the extension of the principle of free trade to the eastern zone. They form the last section of Art. 1:

"It is expressly recognised that in extending the principle of free trade to this eastern zone, the Conference Powers only undertake engagements for themselves, and that in the territories belonging to an independent. sovereign State this principle shall only be applicable in so far as it is approved by such State. But the Powers agree to use their good offices with the Goremments establishel on the African shore of the Indian Oeean fop the purpose of obtaining such approval, and in any case of securing the most favourable conditions to the transit [traffic] of all nations" (cp. §§ 208, 209).

\section{(b) The Zambesi and Shiré.}

331. Questions in Parliament.

On May 17th, 1888, questions having been asked in the House of Commons as to whether the British Government would take steps to protect British traders and Scotch missionaries 
on the Zambesi river from the encroachments and usurpations of the Portuguese Government and their subjects, who, besides imposing transit duties, apparently prevented British vessels from coasting, and demanded that they should fly the Portuguese flag or coase trading . . . - Sir James Fergusson, UnderSecretary of State for Foreign Affairs, made a reply, the following passage of which ereated some, excitement in Portugal (b):

“. . . . I say that Her Majesty's Government distinctly. do not resognise unlimited claims on the part of Portugal in the interior of Africa. The conditions by which the spheres of influence of European Powers in South Africa are bounded aro perfectly well known. Those spheres of influence are not recognised, except where settlements take place, and where a Power possesses the means of maintaining order, protecting foreigners, and controlling the natives. Whore a Power, though seated on the sea-coast, has made no approach to a settlement. in the interior, and no step in the fulfilment of international duties, it is evident that we cannot recognise that it has any claim to deny us free commerce with the interior by a natural highway. Thus Her Majesty's Government cannot for a moment admit a right on the part of such a Power to stop the fres passage of the Zambesi, which gives access to regions where the enterprise of our fellow-countrymen has already made considerable progress." "It is a matter of regret," he then added, "that our commerce should be hindered by heavy charges; but where no international obligations interpose, it is in the power of Portugal or any other country to levy such duties as she may impose within her own territory. . . ."

In the course of the discussion, Mr. Bryce then said: ". . . . He hoped he was correct in understanding that it was the intention of the Government that there should be free and open navigation of the Zambesi. The free navigation of that river was a matter of great importance to this country, and he thought that Her Majesty's Government should not admit any interference with that policy, which would, ho

(b) Hansard, 1888, 5th vol., col. 599. 
believed, make it one of the great highways of commerar . . ." (ibia.., col. 601).

\section{Senhor Barros Gomes' Note.}

The direct result of this discussion was a long note of Senhor Barros Gomes to Senhor d'Antas, dated Lisbon, May 28th, 1888, and communicated to the Marquis of Salisbury by Senhor d'Antas on June 11th $(c)$. It developed the arguments on which the Portuguese Government relied " in affirming Portugal's right freely to regulate the navigation and trade of the Zambesi, and denying the theory that actual occupation constitutes at the present day the essential condition which justifies the possession and the sovereignty in the interior regions of Africa. . ."

"Immediately on the opening of the Berlin Conference," the note ran, "and when its programme was marked out, his Highness Prince Bismarck clearly pointed out that the free access to the flags of all nations, which it was the intention to establish in regard to the rivers of Africa, should be limiter to the two rivers Zaïre and Niger. Freedom of navigation orer the other great fluvial arteries of Africa, while deserwing the sympathies of Germany, could only be affirmed in conventions or treaties strange to the labours and deliberations of the Confierence." On the discussion of the enlargement of the so-called commercial basin of the Congo, and its extension to regions of the eastern coast, several reservations were made in Protoco's 3 and 4 with regard to existing sovereignties. "All these reservations on our part, and the recognition of our rights by others," the note went on to say, " neferred to the free trade which was to be established in the so-called basin of the Congo."

At the session of December 18th, 188t, Sir Edward Malet "once more expressed a desire that the principles adopted by the Conference should be madre applicable to other rivers of Africa, especially the Zambesi. The Marquis of Penafiel, in aflirming the sovereignty of Portugal over the entire narigable course

(c) Parliamentary Papers, Africa, No. 2 (1890) [C. 5904], No. 41. K. 
of the Zambesi, declared that as the question formed no part of the programme of the Conference, the Portuguese Government eould admit no diseussion on such a subject, and reservod to itself the right whieh belonged to it to apply to that portion of its dominions the prineiples which aceording to cireumstanees it might deem to be most opportune." From these and other statements and reservations which it mentioned, the note then inferred that "Portugal's historic rights over the Zambesi, and her claim, therefrom resulting, to legislate in perfect freedom as regards the eonditions for its navigation, reeeived, even if it had hitherto been wanting, their most solemn confirmation in the labours and resolutions of the Berlin Conference."

Abankloning the discussion of the Berlin Conference, the note further referred to older treaties: "The very treaties en-" terel into between Portugal and England in the years 1879 and 1884, and known amongst us as the Lourenço Marques and Zaire Treaties, are also, even though they have not arrived at ratification, a proof that the Gorernment itself of Her Britannic Majesty has solemnly recognised these same rights which Sir James Fergusson's speech now call in qunstion. In the former of the said treaties, that of May 30 th, 1879, the following is laid down in Art. 3:

"The navigation of the Zambesi and its affluents shall be free and not subjeet to any monopolies or exclusive coneessions."

"In the same way, the Treaty of Fobruary 26th, 184t, stipulated as follows in Art. 3 :

"The High Contracting Parties recognise the entire freedum in respect to commerce and navigation of the rivers Congo and Zambes: and their afluents, for the subjeets and flags of all nations.

"The claims of Portugal on the Shire shall not extend beyond the confluenee of the river Ruo with that river" $(d)$.

In these treaties, Portugal saw in the above quoted and other elauses a eompensation for adrantages guaranteed in the

(d) The whole treaty may be found in Hertslet, St. Pap. 1883-84, vol. 75, p. $47 f$. 
same instruments by Great Britain; and in their negotiation Portugal sees a proof that "Great Britain herself has admitted in the most official form that the desired freedom of navigation on the Zambesi cannot be established without [Portugal's] consent."

The end of the note shows, however, that Portugal was ready to barter what it was not ready to grant, for we read: "The Government of His Most Faithful Majesty might establish . . . secure guarantees so soon as it should receive from Her Britamnic Majesty's Government other guarantees of a political character. . . ."

\section{The Marquis of Salisbury's reply.}

The Marquis of Salisbury dealt with the foregoing note of Senhor Barros Gromes in a letter to Mr. Petre, dated Foreign Office, June 25th, 1888 (e).

After stating that it has never bieen disputed that at the Conference of Berlin the question of the Zambesi was not among those selected for discussion, and that the prior rights of existing sovereignties on the East Coast were respected under the Act, and after admitting that a portion of the main stream of the Lower Zambesi is included in the colony of Mozambique, the note points out that the British Gorernment and the British public are much interested in the welfare of the British settlements, the aceess to which from the sea is by the rivers Zambesi and Shiré.

"Portugal made a solemn declaration," the Marquis of Salisbury wrote, "through her aceredited representatire at the Berlin Conference, that she had adopted, as far as she was concerned, the system of free navigation on the Zambesi. She was also a party to the general engagement recorded in the first article of the Berlin Act, under which the Powers bound themselves to facilitate and promote freedom of transit through existing sovereignties. She has therefore pledged herself to a liberal and enlightened policy as regards the portion of the main Zambesi under her eontrol.

(e) Parliamentary Papers, Africa, Nn. 2 (1890) [C. 5901], No. 49. 
"But even if she had given no such pledge, this country could not admit her right to inaugurate a system which would practically result in the exclusion from the waters over which she has control of all British ships wishing to pass beyond those waters. Sir J. Fergusson's remarks in the House of Commons were in this sense; and I should wish you to state to Senhor Barros Gomes that they accurately expressed the views of Her Majesty's Government."

\section{Modus vivendi and Portuguese Decree of 1890.}

On August 20th, 1890, a convention was drawn up by the representatives of Great Britain and Portugal, Arts. 12 and 13 of which practically contained an Act of Navigation for the Zambesi: but, owing to the opposition of the Portuguese Chamber of Deputies, it was not ratified $(f)$.

On November 14 th, 1890 , an agreement recording a modus rivendi was then entered into by the two countries, whereby the Portuguese Government engaged to decree at once the freedom of the navigation of the Zambesi and of the Shiré, to permit and facilitate transit over the waterways of the Zambesi, the Shiré, and the Pungwé, and also over the landways which supply means of communication where these rivers are not navigable, \&c. . .

Four days later a Portuguese decree was issued, containing the following provisions:

Art. 1.-The navigation of the rivers Zambesi and Shiré, in so far as they are under the sovereignty, protectorate, or influence of Portugal, is free for the vessels of all nations in accordance with the principles which the Grovernments of France and Great Britain agreed to establish on the Niger, in virtue of the General Act of the Conference of Berlin in 1885 .

Art. 2.-The Governor General of the Province of Mozambique will submit the necessary regulations for the

(f) The circumstances of the non-ratification are set forth in a note following the text of the Convention in Hertslet's Map of Africa by Treaty, II., pp. 726, 727 (edition in two vols.). 
safety and police supervision of the said navigation, which regulations must be drawn up in the sense of facilitating the passage of merchant vessels.

Art. 3.- Any laws in opposition thereto are hereby revoked.

335. Treaty of Lisbon, June 11 th, 1891.

The definitive state of things was brought about by the treaty between Her [Britannic] Majesty and His Majesty the King of Portugal, defining their respective spheres of influenee in Africa, signed at Lisbon on .June 11th, 1891; the ratifications of which were exchanged in London on July 3rd, $1891(g)$.

Art. 12 provides for free navigation for all flags and freo transit orer waterways and landways. It runs:

"The navigation of the Kambesi and shiré, without " $\mathrm{x}-$ cepting any of their branches and outlets, shall be entirely free for the ships of all nations.

"The Portuguese Government cugages to permit and to facilitate transit for all persons and goods of erery deseription over the waterways of the Zambesi, the shire, the Pungwé, the Busi, the Limpopo, the Sabi, and their tributaries, and also over the landways which supply means of communication where these rivers are not navigable."

Art. 13 then provides for absolute equality of treatment in all circumstances for the subjects and flags of both the contracting Powers. No exclusive privileges, no restrictions or obligations, no tolls or transit dues are allowed. The only. admitted taxes or duties are for services rendered to navigation itself, and no discrimination is allowed.

The régime of the river extends in all respects to its affluents and dependencies, i.e., the roads, paths, railways, lateral canals, \&e., that may be constructed to obviate the non-navigability of certain sections of the river. Tolls calculated on the cost of construction, maintenance and management, and on the

(g) Parliamentary Papers. Portugal No. 1 (1891) [C. 6375]. 
profit aluc to the promoters, may here bo levied, strangers and natives being treated on a footing of perfect equality.

Then follow mutual and identical engagements by Portugal and Great Britain to apply the foregoing prineiples on the waters of the Zambesi, its affluents, \&c., under their respective sovereignty, protection or influence.

The article finally prorides that "any questions arising out of the provisions of this article shall be referred to a joint Commission, and in case of disagreement to arbitration "; but another system of administration and control may be substituted by common consent.

Finally, Art. 14 stipulates for freedom of passage for all merchandise, and for the construction of a railway and a road, between the British sphere of influence and Pungwé Bay.

\section{(c) This Act of Navigition for the Niger conipared with TH.T FOR THE CONGO.}

336. Art. 26 of the Final Act, identical with Art. 13 (\$ 188-191).

Art. 27, same as Art. 14 (\$§ 193-202); but in $\$ 193$ " not expressly stipulated for by the present Act" is replaced by "based only on the fact of navigation"; and $\$ \S 198-202$ are replaced by this only: "The tariff of these taxes or duties shall not warrant any differcntial treatment."

Art. 28, same as Art. $15(\$ 207)$, but $\$ 208$ is suppressed.

Art. 29 , same as Art. $16(\$ \S 210-211)$, but in $\S 210$ " and other waterways assimilated to them by Art. 15 " is replaced. by "branches and outlets."

Arts. 17-24 dealing with the Intermational Commission of the Congc are replaced by the following Arts. 30-32:

Art. 30.-Great Britain undertakes to apply the principles of freedom of navigation enunciated in Arts, 26, 27, 28,29 , on so much of the waters of the Niger, its affluents, branches and outlets, as are or may be under her sovereignty or protectorate.

Tho regulations which she may establish for the safety and control of navigation shall be drawn up in a way 
ealculated to facilitate, as far as possible, the traflic of merchant ships.

it is understood that nothing in these obligations shall be interpreted as preventing or tending to prevent (pouvant empêcher) Great Britain from making any regulations of navigation not contrary to the spirit of these engagements.

Great Britain undertakes to protect the foreign merchants of all nations trading in the ports of the course of the Niger which are or may be under her sovereignty or protectorate, as if they were her own subjects, provided, howerer, that such merchants eonform to the regulations which are or may be made in virtue of the foregoing.

Art. 31.-France accepts, under the same reservations, and in identical terms, the obligations reeognised (consacrées) in the preeeding article, in rospeet of so much of tho waters of the Niger, its affluents, branches, and outlets, as are or may be under lrer sovereignty or protectorate.

Art. 32.- Each of the other signatory Powers binds itself in the same way in case it should ever exereise in the future rights of sovereignty or protectorate over any portion of the waters of the Niger, its affluents, branches and outlets $(h)$.

Art. 33, same as Art. 25 (\$\$ 254-255), but in $\$ 2.54$, read "mouths and outlets" twice, instead of "mouths"; in $\$ 2.55$ read "Art. 29" instead of "Arts. 15 and 16": and suppress $\$ 257$.

(h) As an application of Art. 32, Art. 6 of the Agreement of Nov. 15th, 1893, between Great Britain and Germany may be quoted: "Great Britain recoguises her obligation to apply, as regards the portion of the waters of the Niger and its affluents under her sovereignty or protectorate, the provisions relating to freedow of navigation enumerated in Arts. 26, 27, 28, 29, 30 and 33 of the Act of Berlin of February 26th, 1885. Germany on her side recognises her obligation, under the 32nd Art., to be bound by these provisions as regards the portion of the waters under her eontrol." 


\section{APPENDIX IV.}

\section{TWO TREATIES RELATIVE TO THE DANUBE.}

337.-I. Treaty between Groat Britain, Austria, Germany (Prussia), Italy, Russia and Turkey for the revision of certain stipulations of the treaties of 30 th March, 1856, relative to the Black Sea and Danube. Signed at London, 13th March, $18 \pi 1$.

Art'. 4.-The Commission established by Art. 16 of the Treaty of Paris, in which the Powers who joined in signing the treaty are each represented by a delegate, and which was charged with the designation and execution of the works necessary below Isaktcha to clear the mouths of the Danube, as well as the neighbouring parts of the Black Sea, from the sand and other impediments which obstruct them, in order to put that part of the river and the said parts of the sea in the best condition for navigation, is maintained in its present composition. The duration of that Commission is fixed for a further period of 12 years, counting from the 24th April, 1871, that is to say, till the 24th April, 1883, being the term of the redemption of the loan contracted by that Commission, under the guarantee of Great Britain, Germany, Austria-Hungary, France, Italy and Turkey.

Art. 5.- The conditions of the re-assembling of the riparian Commission, established by Art. 17 of the Treaty of Paris of the 30th March, 1856, shall be fixed by a previous understanding between the riparian Powers, without prejudice to the clause relative to the three Danubian Principalities; and in so far as any modification of Art. 17 of the said treaty may be involved, this latter shall form the subject of a special convention between the co-signatory Powers. 
Art. 6.-As the Powers which possess the banks of the part of the Danube where the Cataracts and the Iron Gates obstruct the navigation reserve to themselves to come to an understanding with the view of removing those impediments, the High Contracting Parties recognise from the present moment their right to levy a provisional tax on the merchant vessels of every flag which may henceforth benefit thereby, until the $\mathrm{x}^{-}$ tinction of the debt contracted for the execution of the works; and they declare Art. 15 of the Treaty of Paris of 1856 to be inapplicable to that part of the river for a space of time necessary for the repayment of the debt in question.

Art. 7.-All the works and establishments of every kind created by the European Commission in execution of the Treaty of Paris of 1856 , or of the present treaty, shall continue to enjoy the same neutrality which has hitherto protected them, and which shall be equally respected for the future, under all circumstances, by the High Contracting Parties. The benefits of the immunities which result therefrom shall extend to the whole administrative and enginoering staff of the Commission. It is, however, understood that the provisions of this article shall in no way affect the right of the Sublime Porte to send, as heretofore, its vessels of war into the Danube in its character of territorial Power.

Art. 8.-The High Contracting Parties renew and confirm all the stipulations of the treaty of the 30th March, 1856, as well as of its annexes, which are not annulled or modified by the present treaty.

338.-II. Treaty between Great Britain, Austria-Hungary, France, Germany, Italy, Russia and Turkey, relative to the navigation of the Danube. Signed at London, 10th March, 1883 .

Art. 1.-The jurisdiction of the European Commission of the Danube is extended from Galatz to Ibraïla.

Art. 2.-The powers of the European Commission are prolonged for a period of 21 years, dating from the 24th April, 1883 
At the expiration of that period, the powers of the said Commission shall be renewed by "tacite reconduction" every three years, unless one of the High Contracting Parties should notify, one year before the expiration of one of these terms of three years, the intention of proposing modifications in the constitution or in the powers of the Commission.

Art. 3.-The European Commission shall exercise no effective control over the parts of the Kilia branch, both banks of which belong to one of the riparian States of that branch.

Art. 4.-With regard to the part of the Kilia branch which flows between the Russian and the Roumanian territory, and in order to ensure uniformity in the régime of the Lower Danube, the regulations in force on the Sulina branch shall be applied under the superintendenoe of the Russian and Roumanian delegates to the European Commission.

Art. 5.--In case Russia or Rumania should undertake works in the Kilia branch, either in the part whioh divides their respective territories, or that which flows exclusively within the territories of either of them, the competent authority shall communicate the plans of these works to the European Commission with the sole view of establishing that they do not interfere in any way with the condition of navigability of the other branches.

The works which have already been carried out at the Tehatal of Ismaill remain at the charge and under the control of the European Commission of the Danube.

Should there be a difference of opinion between the Russian or Roumanian authorities and the European Commission with regard to the plans of the works to be undertaken in the Kilia branch, or should there be a difference of opinion in that Commission with regard to the extension which it might be advisable to give to the works of the Tehatal of Ismaïl, the case should. be submitted directly to the Powers.

Art. 6.--It is understood that there shall be no restriction upon the right of Russia to lery tolls intended to cover the oxpenses of the works undertaken by her.

Nevertheless, with the view of safeguarding the reciprocal 
interests of the navigation on the Sulina branch and on the Kilia branch, the Russian Govermment shall-in order to ensure agreement on the subject-put the Governments represented in the European Commission in possession of the toll regulations which they may think advisable to introduce.

Art. 7.- The regulations for the navigation, river police, and superintendence drawn up on the 2nd Jume, 188\%, by the European Commission of the Danube, assisted by the Delegates of Servia and Bulgaria, are adopted as annexed to the present treaty, and are declared applicable to the section of the Danube between the Iron Gates and Ibraila.

Art. 8.- All the treaties, conventions, Acts, and arrangements relating to the Danube and its mouths are maintained in all such of their provisions as are not abrogated or modified by the preceding stipulations. 



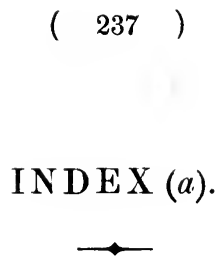

Access to the SEA, $31,81,82,86,89,98,319$ to 322 .

Act of Navigation (1857), 126 to 139,143 (4).

Additional Art. to, 140. v.Congo, Niger, Danube, Elbe, etc.

Adams (Mr.), 320. v. Law of Nature, St. Lawrence.

Affluents. See Tributaries.

Alluvio, 9.

Alveus, 7.

Amakuru (The), 27.

Amazon (The), 28G, 326.

Andrassy (Count), 150.

ANTWERP TO BE A PURELY COMMERCIAL PORT, $76 \mathrm{n}$.

Appeal, 41, 58, 82 p. 66, 232, 234, 301. v. Tribunals.

Apponyi (Count D'), 145.

Aqua profluens, 8.

Arbitration, 335.

Argentine (Confederation), 182, 327, 328.

Assimilation (System of), 82, 92, 311, 315, 316.

AUSTRIan INTERPRetation

of the principles of the Congress of Vienna, 135.

of the stipulations of the Treaty of Paris (1856), 136.

A ustria,

attitude of, with regard to free navigation, $28 \mathrm{~B}$.

treaty with Serbia, 318. v. Danube, Poland (Rivers of).

"Axe du Thalweg," 283.

(a) The figures refer to $\S \S$. 
Banning (M.), 186.

Barima (The), 27.

Barrìre (his project), 167, 169.

Barros Golies (Senhor), 332.

Basin. $v$. Conventional zone.

Belgiojoso (Count de), 31.

Belgium. v. Scheldt, Conference of London, Conference of Berlin (1885), Elbe, Meuse.

Berlin. v. Conference, Congress, Treaty.

Bessarabia, 98, 150 .

Bismarck (Prince ron), 150, 182.

Bolivia, 328.

Boundary RIVers. v. Rivers, Thalweg.

Brazil. v. Amazon.

Bremen (Free city of). v. Weser.

BRIDGES, 88, 296.

British-Venezuelian boundary dispute, Arbitration award, 27.

Brunshausen tolls. $v$. Elbe.

Bug (The), 311.

Bulgaria, 166, 172.

Buol-Schilensteix (Count), 99, 105, 110, 111, 115.

Broymg, 90, 91, $93 \$ 2,94,96,97,328$. v. War Buoying.

Bush (M.), 271.

Busi (The), 335.

"Cabotage." See Coasting Trade.

Campo-Formo. $v$. Treaty.

Canals, 208, 324, 330, 335.

Caratheodory's proposition, 18 n, 21. 
Castquiare (The), 326.

Central Commissiox (Rhine Regulations, 1815), 59.

Cernavoda, 98.

Clancarty (Lord), 47 n., 53, $56 \mathrm{n}$.

Clarendon (Earl of), 112.

Coasting trade, 51, 128, 133, 140I, 189, 288, 306, 308, 315, 326,328 .

Commissiries, $41,59,93 \$ \S 2$ and $6,94,96$.

Commssioners. $v$. Commissaries.

Conimissions,

Central, 59 .

European, 99, 100 (iv), 103, 120, 123, 141 to 144,146 , 162,175 and $n ., 179(4)$.

International (Congo), 215 to 251, 267.

Mixed, 166 to $169,176,313$.

Riparian, 20, 49, 67, 80, 100 (v), 109, 122, 131, 299.

CoMMion ADMINistration ON INTERNATION.L RIVERS, 34,40 , 49.

"Commuxilté," 36, 49.

Compulsory hgreenent to regulate free navigation, 278.

Conference

of Ratisbon (1802), 34 .

of Loudon (1830-1839), 90 to 93.

of Vienna (1855), 99 to 106.

of Paris (1866), 143 .

of London (1871), 145, 337.

of London (1883), 171 to $178,338$.

of Berlin (188t-5), 181 to 274 .

Congo (The),

Act of Navigation, 188 to 265, 336. $v$. Conventional zone, Conference of Berlin.

Congress

of Rastart (1797-8), 34, 283.

of Vienna (1815), 47 to 79.

of Paris (1856), 107 to $117,125$.

of Berlin (1878), 148 to 161 .

Consensus of Cirilized N.1Tions, 26 to 29,275 . 
Constantza, 98.

Convention of Paris on the Rhine Tolls, Aug. 15th, 1804, 35 to 42 .

\section{Convention}

between Austria and the Duchies of Modena and Parma (1849), 312.

between Austria and Russia (1818), 311.

of Belgrade (1882), 318 .

of Berlin (1825), 310.

of Bucharest (1866), 317 .

of Dresden (1819), 305.

of Hamburg (1821), 306.

of Lima (1851), 326.

of Minden (1823), 308.

of St. Petersburg (1840), 92 (n), 98.

between Spain and Portugal (1835), 315. v. Scheldt.

Conventional sistem, growth of, $24,25,26$. Its development is dealt with in Part II. See under each river.

Conventional zone (Congo), 209, 330.

Co-operatios. See International co-operation.

Cordeiro (M.), 186.

Courcel (Baron de), 184, 209, 261.

Courts of Justice, 58. $v$. Tribunals.

Cowlex (LORD). His objections to the Act of Navigation $(1857), 133,143(4)$.

Crimeax War, 98.

Crowe (M.), 186.

Custom, distinguished from usage, $26 \mathrm{n}$.

Customs, 39, 50, 61, 7t, 178, 292, 315, 316, 317.

Czecheny (Count), 98.

Dalberg (Duc de). Project of Regulations for the Rhine (Congress of Vienna, 1815), 47 (n.), 48, 49, 53 (p. 46).

Danube (The), 98 to 179 .

de Bourqueney (Baron), 99, 103. 
Definitive detalled Regulations, provisions for the drawing up of, 64, 75, 93 ( $\$ 6), 122,126$.

de Laveleye, Emile, advocates neutralization of the Congo, 181.

DeNMARK. $v$. Elbe.

Discriminative treatment (exclusion of), 27, 68, 93 ( $\$ 2$ ), 121,133 (2), 189, 190, 201, 211, 251, 284, 335 .

Disputes relative to Navigation, settlement of, $41,58,82$, $142,146,232,301$.

Dobrutcha, 150 .

Douro (Tine), 315, 316.

Dual control. $v$. Supervision (Common).

Dues, $\tilde{5}, 11$.

Art. 110 of Vienna (1815), 69.

Arts. 15 and 16 of Paris (1856), 119, 121.

Art. 14 of the Act of Narigation for the Congo (1885), 193 to 206.

Clause of Art. V. of the Treaty of Paris (1814) concerning, 46.

Collection of, 40, 54 (a), 57, 71, 82 (p. 65).

Dues on native vessels (Congo), 205.

Equitable limitation of, by Grotius, 12 .

Express exclusion of differential dues. $v$. Discriminative treatment.

For defraying the expense of works, 145, 159 (A), 317. $v$. Danube, Congo.

Heidelberg Regulation, 285, 290, 291.

Necessity for uniform system of, 56 .

Rhine Regulations (1815), 56, 57.

Separation from customs, 61,74 .

Suppression of certain, 38, 60. v. Staple, Scheldt, Stade, Tolls.

Duna (The), 310.

Eastern question, 148.

Elbe (The), 28 (p. 28), 305 to 307.

ENGelhardt (Ed.), 82 (p. 65), 186.

K. 
Equal treatuent for all, 93, 121, 181, 190, 201, 211, 284, 313. $v$. Discriminative treatment.

European Commission.

Prolongation of the, 138, 141, 143 (2), 144, 145, 149 (2), $156,175,337,338$.

Extent of its powers, 120, 142, 143 (3), 149 (2), 153 (3), 155, 171, 338. v. Commissions.

Executive authorities over international Rivers, 297 to 300 .

Exterritoriality, $155,162,220$ to 225.

Fergusson (Sir James), 331 to 333.

Feudalism (Influence of), 5.

Fishing, 93, 96 (p. 80).

Floating property in time of War, 261, 304, 315.

Flumen, 7 ; res publica jure gentium, 8.

Flumina perennia, $8 \mathrm{n}$.

Flumina torrentia, $8 \mathrm{n}$.

Fontainebleau. $v$. Treaty.

Forced harbour dues, 38, 54b, 306.

Fortifications, 100 vi., 149 (1), 154.

France, attitude of, with regard to free navigation, 28D. $v$. French Decree, Rhine, Danube, Congo, Scheldt, etc.

Freedom of navigation,

Art. V. of Paris (1814), 43, 45.

Art. 109 of Vienna (1815), 68, 79.

Art. 15 of Paris (1856), 118.

Art. 13 of Berlin (1885), 188 to 192.

Art. 3 of Heidelberg Regulation, 280.

During war, 42,50 (8), 62, 254 to $264,286,315,328$. For all flags, 3 (в), 45, 53, 79, 81 (n.), 93, 174, 182, $188,189,190,192,275,280,314,317,328,334,335$.

For the riparians only, $52,53,82,315,316,327$.

Restrictions in favour of the riparians, $82,85 . v$. Coasting trade.

Whether a right. 23,26 to $29,275,276,321$ to 324 . 
Free ports, ETC., 88, 95 (c \& D), 292.

Frelinghuysen (Mr.), 270.

French Decree (Nov. 16th, 1792), 16, 32, 319 (n. b).

Galatz. v. Danube, Regulations.

Germany,

Agreement relating to Niger, 336 (n.).

Attitude of, with regard to free navigation, 28 (A).

Prussian law on shipping dues (1911), 87 (n.). $v$. Rhine, Seheldt, Danube, Congo.

Gortchakoff (Prince), 99, 102, 103, 105.

Great Britain,

Attitude of, with regard to free navigation, $28 \mathrm{c}$.

and the Niger, 183, 266. $v$. Congress, Conference, Scheldt, Danube, Congo, St. Lawrence, Amazon, Zambesi.

Grotius, 11 to 16 .

Haff (The), 309. $v$. Poland (Rivers of).

HALL, 26 (A), 27.

Hamburg (Free city of). $v$. Elbe.

HANOVER, 306, 307.

Hatzfeldt (Count), 261.

Haymerlé (Baron),

His proposition, $149,150$.

Holland. $v$. Rhine, Scheldt, Meuse.

Holy See, 313.

HüBNER (BARON),

His defence of the Act of Navigation (1857), 134, 139.

Humboldt (Baron von),

Memorandum preparatory to the work of the Commission of Navigation of the Congress of Vienna, 50, 53, $55,56,57,60,61,62,66$.

HydrotechNical works, 88,317 . $v$. Works of improvement. 
IbraIla, 143 n., 338. v. Danube.

ImMUNity OF ESTABLIShMENTS AND STAFF IN WAR, $287,315$. $v$. Neutrality, Inviolability.

IMPERFECT RIGHT, Meaning in Vattel, 13; in Westlake, 26B esp. note; British contention, 321.

INFLUENCE (SPheres OF), 334, 335.

INNOCENT PASSAGE (Right of), 13; Extent of application of the doctrine of, 14,322 .

INSPECTORS, 40, 59, 82, 88, 93, 96, 142, 146, 241, 300, 301.

Institut DE Droit InternationaL wishes to apply freo navigation to Congo, 181; Regulation of Heidelberg (1887), 277 to 304; Resolutions of Madrid (1911), 295 .

INTERdePENDENCE OF INTERESTS, 2, 3, 22, 24, 295 (n.).

Interests of Nations. $v$. Interdependence.

INTERMEdIATE WATERWAys (connecting Belgium with the Rhine), 86, 93 (4,5 and 8), 95 .

INTERNATIONAL CO-OPERATION, 19.

INTERVENTION OF THIRD PARTIES, sometimes necessary, $19 \mathrm{n}$.

Inviolability of members, etc. of International CommisSION, 219, 224, 226, 257, 287. v. Immunity.

Iron Gates (Danube), 145, 159, 161, 164, 178.

Isaccea. v. Danube.

Italy, Attitude of, with regard to free navigation, $28 \mathrm{E}$. $v$. Pô, Conference of Berlin (1889), Danube.

JosEpH II., 24, 31 .

Jus Utilitatis INNoxie, 13.

KaPNist (Count), 125; Reservations at Berlin Conference (1885), 227, 271 to 273 . 
Karolyi (Count), 173.

KASsON, Mr.,

His proposition, 260 to 262 .

His reservations, 270,274 .

Kilia Br.1xcil, 174, 338. v. Danube.

Kirsélew (Count), 139.

KöNigsberg (PORT OF), 309.

Kusserow (M. DE), 186, 261.

Lake Michigan, 324,32 .

Lakes (Central Africa), 208, 330.

Lambermont (Baron), 186; His report to the Conference of Berlin (1884-1885), 192, espee. note (k), 261, 272. $v$. Congo.

Law of Nature (Influence and authority of ), 4, 10 .

Use of, by Grotius and Vattel, 12 to 14.

Historical appeals to, 16 .

Jefferson and, 319.

Adams and, 320.

British contention, 321.

Leck, Prolongation of the Rhine in Dutch territory, 54c, $81,82,84$.

LEGAL THEORIES AND PRINCIPLES CONCERNING INTERNATIONAL RIVERS, $\tilde{5}$ to 16 .

LiCENCE, 82, 306, 315, 317.

Lightrouses, 158. v. Dues and duties.

Limits (Treity of). v. Treaty, Scheldt.

Liмpopo (The), 325.

LOAN, guaranteed by the Powers, 144 .

for technieal and administrative expenses, 142, 144, 247 to 251 .

London. $v$. Conference, Treaty.

Madeira (The), 326. 
MaIN (The), 65, 76.

Maintenance and improvement of navigability. See Navigability, Hydrotechnical works, Works of improvement.

Malet (Str Edw.), 183, 184, 275.

Mannheim. $v$. Regulations.

Marcy (Mr.), 28G.

Martix Garcia (Island of), 328.

Mayence. $v$. Regulations.

Metternich (Prince), 143.

Meuse (The), 65, 76, 81, 95.

Michigan. $v$. Lake.

Mississippi (The), 16, 24, 319.

Monopolies and Privileges, suppression of, 60, 190, 306, $308,313,315$.

Moselle (The), 65, 76.

Münster (Count), 172 .

Münster. $v$. Treaty.

Nature (RIGHT OF). $v$. Law of nature.

Navigability (Preservation of), 64, 72, 86, 88, 92, $93 \S \S 2 \& 8,94,97,141,218,236,296,317$.

Navigation. $v$. Freedom of.

Navigation free for neUtrals in time of WAR, 286.

Navigation (The Exercise of), $82,85,128,306,315$.

"Navigation of the Rhive," meaning in the Regulation of Mayence (1831), 82 .

Neckar (The), 65, 76.

Neutrality, Provision of, 42, 62, 142 p. $115,145,149$ (1), 162,257 to 264 . $v$. Immunity of establishments and staff in war. 


\section{Neutralization}

of the delta of the Danube, 106.

of the Black Sea, 108.

of the Congo, 181, 260 to 262 .

Niemen (The), 310.

Niger (The),

Great Britain's reservations with regard to, 183.

Régime of, 266.

Act of Navigation, 336.

Nys (M. Ern.), 76 n., 97 n., 282, 283.

Odessa (PORT OF), 98.

Opening uP OF INternational Rivers. $v$. Rivers.

Oppenherm (Prok. L.), his terminology, $1 \mathrm{n}$.

OrInoco (The), 326.

Orloff (Count), 108.

Paraguay (The), 327, 328.

Parana (The), 327, 328.

Paris. $v$. Conference, Congress, Treaty.

Patent. $v$. Licence.

Permissible dues, 61, 87, 197 to 202, 291, 303. $v$. Dues.

Peru. v. Amazon.

Pierce (President), 326.

Prlotage, 90, 91, 93 § 2, 94, 95a, 96, 97, 130, 140 IV., 328.

Plate (River), 327, 328.

Plurality of régines on ax international river, 179 (2).

Pô (The), 7ð, 312 to 314 .

Poland, rivers of, $7 \overline{7}, 309$ to 311 .

Police Regulations, 40, 49, 50, 56, 64, 68, 69, 119, 146, $230,293,328$. 
Porcupine (The), 324.

Port dues, 38. v. Dues.

Portugal. v. Congo, Douro, Tagus, Shiré, Zambesi.

Practice of States, 4, 30.

Privileges, suppression of. $v$. Monopolies.

Prohibited does, 60, 73, 93, 94, 194, 196, 290. v. Dues.

Prokesch (Baron), Memorandum of, 100, 104, 105, 106.

Protectorate, 334, 335.

Prussia, 116.

Prussian Bill on shipping dues (1911), 87 (n.). $v$. Rhine, Elbe, Weser, Danube, ete.

Pruth (The), 317.

Public Act (1865), 141, 142, 143 (1); Additional Act (1881), 162. v. Danube.

PuffendorfF, 16.

Pungivé (The), 335.

Quaraxtine. See Sanitary Regulations.

Rallways. $v$. Roads.

Rastadt. $v$. Congress.

Regulations

Between the Iron Gates and Galatz, 157, 173, 178, 338.

Brazilian (1867), 326.

Danube (1857), 126 to 131 .

General (1815), 67 to 75 .

Heidelberg (1887), 277 to 304.

Lower Danube, 146.

Rhine (Paris, 1804), 35 to 42; (Vienna, 1815), 55 to 64 ; (Mayence, 1831), 80 to 82 ; (Mannheim, 1868), 83 to 88.

Scheldt (1843), 96, 97.

Submission of, for approval, 139, 230, 233. v. Police, Quarantine, Act of Navigation, Dues, etc. 
Res publica (juie gentium and jure civitatis), 8.

Rhine, $33,34,35$ to 42,55 to $64,76,80$ to 88 .

RHône, Plans for its connection with Rhine, $29 \mathrm{n}$.

Rio Bravo del Norte (The). $v$. Rio Grande.

Rio Grande (The), 329.

Rio Negro (The), 326.

RIPA, 7.

Riparian Commissiox. $v$. Commission.

RIVERS,

Boundary, 1 (n.), 281, 283.

Double character of questions relative to, 2 .

International, 1 (в).

National, 1 (A).

Opening up of, 3,30 .

Organic unity of, 1.

List of:-

Amakuru, 27.

Amazon, 28 (G), 326.

Barima, 27.

Bug, 311.

Busi, 335.

Casiquiare, 326.

Colorado, 329.

Congo, 188 to 265.

Danube, 98 to 179 .

Douro, 315, 316.

Duna, 310 .

Elbe, 28,305 to 307 .

Gila, 329 .

Haff, 309.

Limpopo, 325.

Leck, 54, 81, 82, 84 .

Madeira, 326.

Main, 65, 76.

Meuse, 65, 76, 81, 95.

Mississippi, 16, 24, 319.

Moselle, 65, 76.

Neckar, 65, 76.

Niemen, 310.

Niger, 183, 266, 336.

Orinoco, 326 . 
RIvers-continued.

Paraguay, 327, 328.

Paraná, 327, 328.

Plate, $327,328$.

Pô, 77, 312 to 314 .

Poland (rivers of), 77, 309 to 311 .

Porcupine, 324.

Pruth, 317.

Pungwè, 335.

Rhine, 33 to 42,55 to $64,76,80$ to 88 .

Rhône, 29 (n.).

Rio Grande, 329.

Rio Negro, 326.

Sabi, 325.

San Francisco, 326.

St. Lawrence, 16, 20, 24, 320 to 325 .

Scheldt, 24, 31, 32, 53 (n.), 65, 76, 89 to 97,319 , 321.

Shiré, 27,331 to 335 .

Stikine, 324.

Tagus, 316.

Tapazoz, 326.

Tocantins, 326 .

Uruguay, 327, 328.

Vistula, 310,311 .

Waal, 81, 82, 84 .

Weser, 308.

Yukon, 324.

Zambesi, 27, 330, 331 to 335 .

Rivus, 7.

Roads, Ratlways and lateral canals

of the Congo, 210 to 214.

of the Zambesi, 335. v. Canals.

RoMAN LAW, 6 to 9, 16, 282.

RUMANIA, 151, 155, 162, 163, 166, 168, 169, 172, 173, 178.

Russell (LoRd John), 103 note, 105.

Rossia, attitude of, with regard to free navigation, $28 \mathrm{~F}$. v. Danube, Conference of Berlin (1885), Poland (Rivers of), Kapnitz, etc.

Russo-Rumano-Turkish War, 147.

SABI (THE), 325.

SAlisbury (LoRD), 150, 333. 
San Francisco (The), 326.

San Stefano. $v$. Treaty.

St. George (Branch of). v. Danube.

St. Lawrence (The), 16, 20, 24, 320 to 325 .

St. Petersburg (Convention of). v. Convention, Damube.

SANDFord, Mr. His proposition to the Conference of Berlin (1884-1885), 214.

Sanitary regulations, $93 \$ 3,94,98,119,130,133$ (8), 134, 140, 142 p. 115, 162, 230, 239, 252, 253, 294.

Scheldt, 24, 31, 32, 53 note $d, 65,76,89$ to $97,319,321$.

Schouvalow (Count), 150, 152.

Serbia, $166,172,318$.

Servitudes,

Classification of French Code criticised, $18 \mathrm{n}$.

International, 18.

ShIre and ZaMbezi controversy, 27, 331 to 335 .

Solidarity, 22.

SovEREIGNTY,

Act of Navigation (1857) asserted to be enforceable by virtue of Austria's sovereign right, 139.

Independence of the sovereign authority, 149 (2), 155, 162.

International co-operation no infringement of, 19.

Limitations of, 18 .

Must be taken into account, 20.

Not to be disturbed, 50 .

Over territorial seas, 81 .

Rights of, 17 to $20,23,42,50,81,91,92,103,134$, $139,155,162,163,173,179,184,220$ to 223,232 , $241,261,268,275,298,308,319,320$.

Right to protect, 321 .

Sacred principle of, 174 .

Sovereignty and executive commissions, 19, 173.

Sovereignty and property distinguished, 17, 18 .

The stock argument of particularism, 17.

Versus joint supervision, 91, 92 .

Versus unified administration, 57 .

Violated, 179 (3). 
Spain. v. Douro, Tagus, Mississippi.

Stade. $v$. Elbe, Tolls.

Staple (Duties of), 38, 307, 308, 309, 310, 318.

"Stationaries" at the Mouths of the Danube, 104, 108, $124,142,149(1)$.

Stikine (The), 324 .

Stipulations inconsistent with tile pRinciples of Vienna (1815), $140 \mathrm{v}$.

Strasbourg (Convention of), 283.

Sulina (Branch of). $v$. Danube.

Supervision (Comaon), 40, 59, 90, $93 \S 2,94$ (b), 96, 97.

Sweden and Norway, 307.

Syndical authority, 99. v. Syndicate (European).

Syndicate (European), 103, 162.

SZEChenyi (Count), 271.

TAGUS (The), 316.

Tapazoz (The), 326.

TARIFFs, 56, 70, 291.

Periodical revision of, 142 p. $115,202,307$.

Terminology, 1.

Terneuzen (Canal of), 95 (b).

Thalweg, 36, 281, 282, 283.

Tocantins (The), 326.

Tolls, Collection of, $39,50,93 \$ 3$.

Abolition of, 94, 306, 307, 318 .

Stade Tools, 307. See also Collection of Dues, Scheldt, Elbe.

Tonnage (Measurement of), 303. 
Towing-Paths, 57, 72, 310, 311, 313.

Transit, 12, 82, 87, 95, 178, 195, 289, 292, 309, 313, 317; 335 .

Treatamest (Equal). $v$. Discriminative treatment.

Treaty

of Assumption (1853), 328.

of Berlin (1878), 153 to 161 .

of Campo-Formio (1797), 33.

of Caracas (1859), 326.

of Fontainebleau (1785), 31.

of Guadalupe Hidalgo (1848), 329.

of Hague (The) (1795), 33.

of Hanover (1861), 307.

of Limits (1842), 95.

of Lisbon (1829), 316; (1891), 335.

of London (1839), 93; (1871), 145, 160, 337; (1883).

171,338 .

of Mexico (1853), 329.

of Milan (1849), 133 (n.).

of Minden (1769), 308.

of Münster (1648), 5, 31, 89.

of Paris (1763), 320; (1814), 43 to 46 (text of Art. V., $44), 89$; (1856), 117 to 124,160 .

of Russia and Prussia (1815), 309.

of Russia and Austria (1815), 309.

of San José de Florès (1853), 328.

of San Lorenzo el Real (1795), 319.

of San Stefano (1878), 147.

of Vienna (1815). $v$. Congress.

of Washington (1819), 319; (1854), 324; (1871), 325.

Tribunals for the settlement of disputes relative to navigation, $58,82,301$. $v$. Disputes.

Tributaries, 34, 69, 87, 133 (3) and p. 106-107, 207, 279, $313,334,335$.

Twiss (Sir Travers),

Opposes neutralization of the Congo, 181 .

At the Berlin Conference (1885), 186, 260.

United States of America,

Attitude with regard to free navigation, $28 \mathrm{G}$.

Conference of Berlin (1885), 181 and $\mathrm{n}$. v. Mississippi,

St. Lawrence, Amazon, Stade Tolls.

Uruguay (State of), 327, 328. 
Uruguay (The), 327, 328.

Use of the stream, 9 (c), 295.

USE OF BANKS FOR PURPOSES ANCILLARY TO NAVIGATION, 9 A.

vaN Der Spaen (Baron), 51.

VATTEL, 11 to 16 .

Venezuela. $v$. Amazon.

VESSELS OF WAR, 154.

Vienna (Congress of), 1815 ,

Applications of the principles of, 78 .

Final Act (text of Arts. 108 to 116), 67 to 75.

General principles for international rivers, 66 to 77 .

Interpretation of Art. 109, 79.

Proceedings of, 47 to 54 .

Rhine Regulations, 55 to 65 .

VIENNA,

Conference (1855), 99 to 106.

Bases of negotiation, 99, 100.

"Villes de station," 37, 38.

Vistula (The), 310, 311.

von Berkheim (Baron), 54.

von Wessenberg (Baron), $47 \mathrm{n}$.

WAAL (The), $81,82,84$.

Walewski (Count), 107 to 111.

War buoying on the Scheidt, 97.

Warehouses. See Free. Ports.

WARShips of RIPARIAN States, 328, p. 220.

War (State of). $v$. War buoying, Freedom of navigation during war, Floating property in time of war.

WAR vesSELS, recourse to, 146, 243, 244, 245, 246.

Weser (The), 308. 
WESTLAKE,

Conclusions of, $26 \mathrm{~B}$.

Discussed, 27.

Wittemberg. $v$. Elbe.

WolfF, 16.

Works of IMProvement, 296, 317. $v$. Navigability, Hydrotechnical works.

YokоN (THE), 324.

Zaïre (The). $v$. Congo.

Zambezi (The), 330, 331 to $335 . \quad v$. Shiré.

Zurich (Peace of), 314. 


THE GROTIUS SOCIETY'S PROCEEDINGS (continued). PROBLEMS OF THE WAR.

VOLUME 3, pullished 1918.

$$
\text { Price 5s. net (\$ } 1.45) \text {. Postage 6il. (12 cents). }
$$

\section{CONTENTS.}

Treaties of Peace. By Sir Graham Bower.

Belligerent Merchantmen in Neutral Parts. By S. D. Cole.

The Black List. By J. E. G. De Montmorevcy.

The Deutschland. By Judge Atherley-Jones.

International Law Teaching. By E. A. Whiтruck.

The Control of Air Spaces. By J. F. G. ne Montmonency.

Legal War Work in Egypt. By Sir M. McIlwraith.

The Revolution and the Unity of Russia. By

L. P. RastoongouefF.

The Relations of the Prize Court to Belligerent Policy. By Sir F. Piggott.

Jus Soli or Jus Sanguinis? By H. S. Q. Henrfoles and E. J. SChuster.

Reciprocity in the Enjoyment of Civil Rights. By W. A. Bewes.

VOLUME 4, to be published ofumury 1919.

\section{CONTENTS.}

The League of Nations. By Rit. HOIn. LORD PARMOOR.

Report of the Committee on the Legal Status of Sub= marines.

Report of the Committee on Nationality and Registration. 
PROBLEMS OF THE WAR (continum).

Sequestration of Merchantmen. By Dr. JANsMa and $\mathrm{IV}$. R. BISCHOPP, LL.D.

The Highways of the Sea. By SAxford D. Cole.

The American Conception of the Freedom of the Sea. By F. W. Hrrst.

The Futy

The Nati

The Bart I'E M

The Treat

Jonks,

LL.D.

Some Sch

DARB

A Maxim

K.C.N

The Righ

T. DER

Divergend

nation

The Freed
年

空 
